UNIVERSIDADE ESTADUAL PAULISTA

CAMPUS BAURU

FACULDADE DE CIÊNCIAS

PROGRAMA DE PÓS-GRADUAÇÃO EM PSICOLOGIA DO DESENVOLVIMENTO

E APRENDIZAGEM

GABRIELA MELLO SABBAG

ANÁLISE DAS PRÁTICAS E DAS HABILIDADES SOCIAIS EDUCATIVAS MATERNAS NA INTERAÇÃO COM OS FILHOS ADOLESCENTES 
GABRIELA MELLO SABBAG

\section{ANÁLISE DAS PRÁTICAS E DAS HABILIDADES SOCIAIS EDUCATIVAS MATERNAS NA INTERAÇÃO COM OS FILHOS ADOLESCENTES}

Dissertação apresentada como requisito à obtenção do título de Mestre à "Universidade Júlio de Mesquita Filho" Programa de Pós- graduação em psicologia do desenvolvimento e aprendizagem da Faculdade de Ciências da UNESP, sob a orientação da Professora Doutora Alessandra Turini Bolsoni-Silva. 
Sabbag, Gabriela Mello.

Análise das práticas e das habilidades sociais educativas maternas na interação com os filhos adolescentes / Gabriela Mello Sabbag, 2010.

$160 \mathrm{f}$.

Orientadora: Alessandra Turini Bolsoni-Silva

Dissertação (Mestrado)-Universidade Estadual Paulista. Faculdade de Ciências, Bauru, 2010. 


\section{AGRADECIMENTOS}

À Professora Doutora Alessandra Turini Bolsoni-Silva pela competência com a qual me orientou e também pelo seu jeito compreensivo, persistente e paciente.

À Coordenação de Aperfeiçoamento Profissional de Nível Superior (CAPES) pelo incentivo dado com a bolsa.

À Professora Doutora Maura Glória de Freitas e à Professora Doutora Lígia Ebner Melchiori que contribuíram excepcionalmente para o aprimoramento deste trabalho.

À Professora Doutora Olga Maria Piazetin Rolim Rodrigues e à Professora Doutora Sandra Callais pelas orientações e pelo apoio que me concederam durante o Mestrado.

À Professora Doutora Paula Inez Cunha Gomide por ter me incentivado a realizar o trabalho acadêmico.

Às mães e aos adolescentes que aceitaram participar desta pesquisa e para os quais eu dedico este trabalho.

Aos meus colegas e amigos do Mestrado pela oportunidade de aprendizagem e pelo carinho que recebi de todos.

Aos meus primos, Carmo e Eduardo, por terem me abrigado com tanto carinho e apoio.

Aos meus pais, Solange e Gabriel, e à minha irmã Fernanda, por sempre me ajudarem em tudo.

Ao meu namorado Vilmar que sempre me incentivou com palavras positivas e alegres.

A Deus por tudo o que tem feito por mim.

A todos que, direta ou indiretamente, contribuíram para este trabalho. 
SABBAG, G. M. Análise das práticas e das habilidades sociais educativas maternas na interação com os filhos adolescentes. 2010. 160 folhas. Dissertação (Mestre em Psicologia do Desenvolvimento e da Aprendizagem)- UNESP, Faculdade de Ciências, Bauru, 2010.

\section{RESUMO}

A literatura nacional e internacional, especializada no relacionamento entre pais e filhos, aponta para a importância de se investigar os estilos e as práticas parentais para o estudo das habilidades sociais e dos problemas de comportamento dos adolescentes. As práticas parentais referem-se às diferentes estratégias que os pais utilizam para educação e socialização de seus filhos. As habilidades sociais utilizadas pelos pais com o intuito educativo são denominadas de habilidades sociais educativas parentais. Essas permitem a transmissão de padrões, valores e condutas ao filho, tornando possíveis a socialização do adolescente e a competência em suas interações sociais. Com base nos estilos maternos de risco e não risco para problemas de comportamento em adolescentes, obtidos pelo Inventário de Estilo Parental - IEP -, a presente pesquisa busca descrever o perfil de interações sociais estabelecidas entre mães e filhos adolescentes, utilizando como instrumento a análise funcional do comportamento. Foram investigadas as habilidades sociais educativas maternas, as práticas negativas, as variáveis contextuais, as habilidades sociais e os problemas de comportamento dos adolescentes. Participaram do estudo 24 mães, das quais 14 foram relatadas pelos seus filhos como tendo estilo de risco e 10, estilo de não risco, o que foi identificado pelo Inventário de Estilo Parental - IEP. Essas mães responderam o Roteiro de Entrevista de Habilidades Sociais Educativas Parentais - RE-HSE-P - e o Child Behavior Checklist - CBCL. As análises globais apontaram diferenças na comparação das habilidades sociais educativas maternas HSE-P - do grupo de risco e de não risco para quase todas as categorias gerais do RE-HSE-P: habilidades sociais educativas maternas, práticas negativas maternas, situações de contexto, frequência de práticas negativas maternas, total de práticas negativas, total de práticas positivas maternas, habilidades sociais dos filhos e problemas de comportamento dos filhos. De modo geral, as mães do grupo de não risco relataram emitir com mais frequência habilidades sociais educativas e menos práticas negativas. Em consequência, seus filhos apresentaram mais habilidades sociais e menos problemas de comportamento. O contrário ocorreu no grupo de risco, no qual as mães utilizaram mais práticas negativas em detrimento das habilidades sociais educativas, e seus filhos consequentemente apresentaram maior frequência de problemas de comportamento. Os dados do CBCL confirmaram os dados obtidos pelo RE-HSE-P sobre a maior incidência de diagnósticos clínicos e borderline em adolescentes da amostra de risco. Os resultados apontam, então, para as relações funcionais entre as práticas, as habilidades sociais educativas maternas e os comportamentos dos adolescentes.

Palavras-chave: Práticas educativas maternas, habilidades sociais educativas maternas, habilidades sociais, problemas de comportamento, adolescência 


\begin{abstract}
The investigation of parental styles and practices and the relation with adolescent's behavior problems and adolescent's social skills is being studied by national and international literature of parents and adolescents relationship. The parent's practices are the different strategies who they use for children and adolescent socialization. The social skills that the parents use with educative intention are called parental educative social skills, which allow the transmission of standards, values and behaviors that make possible the socialization of the child or adolescent and the ability in social interactions. In this context, the present study investigated from the maternal risk style and not risk style, by Parental Styles Inventory IEP-, this research makes the functional analysis of the mother and adolescent interaction, taking account the maternal educative social skills, the negative practices, the context variables, the adolescent's social skills and the adolescent's behavior problems. The participants were 24 mothers, of wich 14 were related by sons like being risk style and 10 like being no risk style, that was identified by Parental Style Inventory. These mothers answered the Parental Social Educative Skills Script Interview - RE-HSE-P-and the Child Behavior Checklist-CBCL. The global analyses showed differences in the comparison of maternal social educative skills from the risk group and the non risk group for almost all the categories from RE-HSE-P: mother's educative social skills, maternal negatives practices, context situations, maternal negative practices frequencies, overall negative practices, overall positive practices, son's social skills and son's behavior problems. In general way, the non risk mother's told more often being educative social skills and less negative practices. By consequence your sons showed more social skills and less behavior problems. The opposite happened on the risk group, that mother's used to be more often negative practices and less educative social skills. By consequence your son's showed more behavior problems. The results of $C B C L$ agree, with $R E-H S E-P$ results, showing more clinical and borderline adolescents from the risk group. The results pointed to functional relations between mother's practices, mother's educative social skills and the adolescent's behavior.
\end{abstract}

Key-Words: Mother's educative practices, mother's social educative skills, social skills, adolescent behavior problem, adolescence. 


\section{LISTA DE FIGURAS}

Figura 1 - Comparação entre amostra de risco e não risco sobre a frequência da subcategoria conversa, das Habilidades Sociais Educativas Parentais (HSE-P) de comunicação.

Figura 2 - Comparação entre amostra de risco e não risco sobre a frequência da subcategoria faz perguntas, das Habilidades Sociais Educativas Parentais (HSE-P) de comunicação.

Figura 3 - Comparação entre amostra de risco e não risco sobre a frequência da subcategoria faz perguntas de sexualidade, das Habilidades Sociais Educativas Parentais (HSE-P) de comunicação

Figura 4 - Comparação entre amostra de risco e não risco sobre a frequência da subcategoria expressa sentimentos negativos, das Habilidades Sociais Educativas Parentais (HSE-P) de expressão de sentimentos e enfrentamento.

Figura 5 - Comparação entre amostra de risco e não risco sobre a frequência da subcategoria expressão de sentimentos positivos, das Habilidades Sociais Educativas Parentais (HSE-P) de expressão de sentimentos e enfrentamento.

Figura 6 - Comparação entre amostra de risco e não risco sobre a frequência da subcategoria expressão de opiniões, das Habilidades Sociais Educativas Parentais (HSE-P) de expressão de sentimentos e enfrentamento.....

Figura 7 - Comparação entre amostra de risco e não risco sobre a frequência da subcategoria expressão de carinho, das Habilidades Sociais Educativas Parentais (HSE-P) de expressão de sentimentos e enfrentamento......

Figura 8 - Comparação entre amostra de risco e não risco sobre a frequência da subcategoria estabelecer limites, das Habilidades Sociais Educativas Parentais (HSE-P) de estabelecimento de limites.

Figura 9 - Comparação entre amostra de risco e não risco sobre a frequência da subcategoria identificar erros, das Habilidades Sociais Educativas Parentais (HSE-P) de estabelecimento de limites.

Figura 10 - Comparação entre amostra de risco e não risco sobre a frequência da subcategoria faz coisas que a mãe gosta, das Habilidades Sociais Educativas Parentais (HSE-P) de estabelecimento de limites..

Figura 11 - Comparação entre amostra de risco e não risco sobre a frequência da subcategoria faz coisas que a mãe não gosta, das Habilidades Sociais Educativas Parentais (HSE-P) de estabelecimento de limites

Figura 12 - Comparação entre amostra de risco e não risco sobre a frequência da HSEP entendimento conjugal....

Figura 13 - Comparação entre amostra de risco e não risco sobre as dimensões do HSE-P..... . .99

Figura 14 - Análise geral do RE-HSE-P comparando os grupos de risco e não risco para problemas de comportamento do adolescente. 


\section{LISTA DE QUADROS}

Quadro 1 - Descrição da categoria comunicação, subcategoria conversa. .153

Quadro 2 - Descrição da categoria comunicação, subcategoria faz perguntas.

Quadro 3 - Descrição da categoria comunicação, subcategoria perguntas sobre sexualidade. 153

Quadro 4 - Descrição da categoria expressão de sentimentos e enfrentamento, subcategoria expressão de sentimentos positivos

Quadro 5 - Descrição da categoria expressão de sentimentos e enfrentamento, subcategoria expressão de sentimentos negativos.

Quadro 6 - Descrição da categoria expressão de sentimentos e enfrentamento, subcategoria expressão de opiniões

Quadro 7 - Descrição da categoria expressão de sentimentos e enfrentamento, subcategoria faz carinho. 156

Quadro 8 - Descrição da categoria estabelecimento de limites, subcategoria estabelece limites.....

Quadro 9 - Descrição da categoria estabelecimento de limites, subcategoria mãe identifica erros .157

Quadro 10 - Descrição da categoria estabelecimento de limites, subcategoria filho faz coisas que a mãe gosta.......

Quadro 11 - Descrição da categoria estabelecimento de limites, subcategoria filho faz coisas que a mãe não gosta

Quadro 12 - Descrição da categoria estabelecimento de limites, subcategoria entendimento do casal sobre a educação do filho 158

Quadro 13 - Classificação dos comportamentos maternos segundo o RE-HSE-P. 159

Quadro 14 - Classificação dos comportamentos dos filhos segundo o RE-HSE-P 160 


\section{LISTA DE TABELAS}

Tabela 1- Idade das mães no grupo de risco e de não risco para problemas de comportamento em adolescentes

Tabela 2 - Idade dos adolescentes no grupo de risco e de não risco para problemas de comportamento em adolescentes.

Tabela 3 - Renda familiar mensal, em salário mínimo e valor em reais, no grupo de risco e de não risco para problemas de comportamento em adolescentes......

Tabela 4 - Estado civil das mães no grupo de risco e de não risco para problemas de comportamento em adolescentes

Tabela 5 - Escolaridade das mães no grupo de risco e de não risco para problemas de comportamento em adolescentes

Tabela 6 - Ocupações ou profissões das mães do grupo de risco e de não risco para problemas de comportamento

Tabela 7 - Características em relação ao serviço, externo ou do lar, das mães do grupo de risco e de não risco para problemas de comportamento em adolescentes.

Tabela 8 - Horário ou jornada de serviço materno do grupo de risco e de não risco para problemas de comportamento em adolescentes.

Tabela 9 - Vínculo empregatício das mães do grupo de risco e de não risco para problemas de comportamento em adolescentes.

Tabela 10 - Características paternas do grupo de risco e de não risco para problemas de comportamento em adolescentes

Tabela 11 - Médias das frequências das práticas maternas e do índice de estilo materno avaliados pelo IEP e aplicação do teste Mann-Whitney para comparação entre os grupos de risco e não risco para problemas de comportamento do adolescente

Tabela 12 - Correlação Spearman das práticas educativas maternas e do índice de estilo materno, obtidos através do IEP, no grupo de risco para problemas de comportamento do adolescente......

Tabela 13 - Correlação Spearman das práticas educativas maternas e do índice de estilo materno, obtidos através do IEP, no grupo de não risco para problemas de comportamento do adolescente.

Tabela 14 - Médias das categorias do RE-HSE-P e aplicação do teste Mann-Whitney para comparação dos resultados do grupo de risco e não risco para problemas de comportamento do adolescente.

Tabela 15 - Comparação das médias de habilidades sociais educativas maternas, do total de práticas positivas maternas e das habilidades sociais dos filhos entre os grupos de risco e não risco para problemas de comportamento do adolescente.

Tabela 16 - Frequência da classificação referente às habilidades sociais educativas maternas, ao total de práticas positivas e às habilidades sociais dos filhos dos grupos de risco e não risco para problemas de comportamento do adolescente.

Tabela 17 - Descrição e frequência dos comportamentos apresentados pelas mães e filhos de ambos os grupos na subcategoria conversa. 
Tabela 18 - Descrição e frequência dos comportamentos apresentados pelas mães e filhos de ambos os grupos na subcategoria faz perguntas......

Tabela 19 - Descrição e frequência dos comportamentos apresentados pelas mães e filhos de ambos os grupos na subcategoria faz perguntas de sexualidade.

Tabela 20 - Descrição e frequência dos comportamentos apresentados pelas mães e filhos de ambos os grupos na subcategoria expressa sentimentos negativos.

Tabela 21 - Descrição e frequência dos comportamentos apresentados pelas mães e filhos de ambos os grupos na subcategoria expressa sentimentos positivos.

Tabela 22 - Descrição e frequência dos comportamentos apresentados pelas mães e filhos de ambos os grupos na subcategoria expressão de opiniões.

Tabela 23 - Descrição e frequência dos comportamentos apresentados pelas mães e filhos de ambos os grupos na subcategoria expressão de carinho

Tabela 24 - Descrição e frequência dos comportamentos apresentados pelas mães e filhos de ambos os grupos na subcategoria estabelecer limites......

Tabela 25 - Descrição e frequência dos comportamentos apresentados pelas mães e filhos de ambos os grupos na subcategoria mãe identifica erros na educação do filho.

Tabela 26 - Descrição e frequência dos comportamentos apresentados pelas mães e filhos de ambos os grupos na subcategoria fazer coisas que a mãe gosta......

Tabela 27 - Descrição e frequência dos comportamentos apresentados pelas mães e filhos de ambos os grupos na subcategoria fazer coisas que a mãe não gosta.

Tabela 28 - Resultados da Correlação Spearman referente às classificações do RE-HSE-P para o grupo de risco para problemas de comportamento do adolescente.

Tabela 29 - Resultados da Correlação de Spearman referente às classificações do RE-HSE-P para o grupo de não risco para problemas de comportamento do adolescente.

Tabela 30 - Médias e aplicação do teste Mann-Whitney para comparação dos resultados do grupo de não risco e não risco para classificação diagnóstica do CBCL.

Tabela 31 - Escores e classificação em população clínica, borderline e não clínico do CBCL em população de risco e não risco para problemas de comportamento do adolescente. .104

Tabela 32 - Frequência de participantes com problemas clínicos, borderline e não clínicos para amostra de risco e não risco. 


\section{LISTA DE ABREVIATURAS E SIGLAS}

CBCL - Child Behavior Checklist

DSTs- Doenças Sexualmente Transmissíveis

HS - Habilidades Sociais

HSE - Habilidades Sociais Educativas

HSEP - Habilidades Sociais Educativas Parentais

IEP - Inventário de Estilo Parental

RE-HSE-P - Roteiro de Entrevista de Habilidades Sociais Educativas Parentais

THS - Treinamento de Habilidades Sociais 


\section{SUMÁRIO}

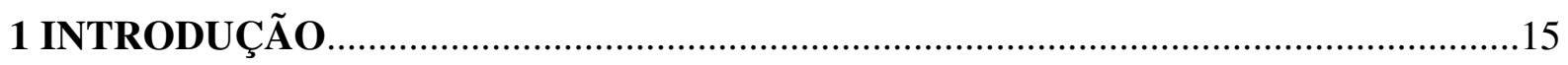

1.1 AS PRÁTICAS PARENTAIS E O COMPORTAMENTO DE ADOLESCENTES.

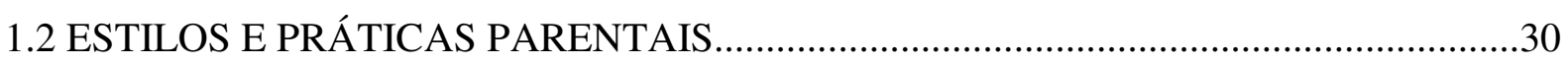

1.3 AS CONTRIBUIÇÕES DA ANÁLISE DO COMPORTAMENTO PARA A RELAÇÃO

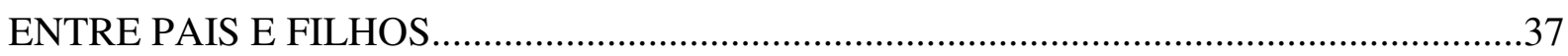

1.4 HIPÓTESES E PERGUNTAS DA PESQUISA..............................................................54

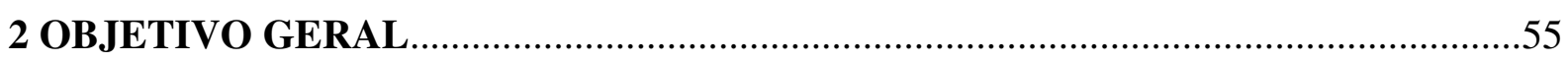

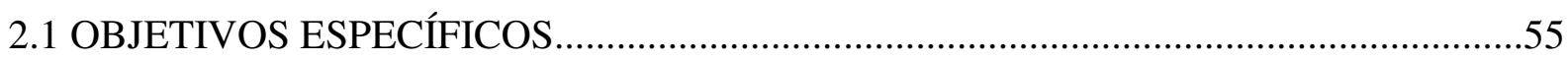

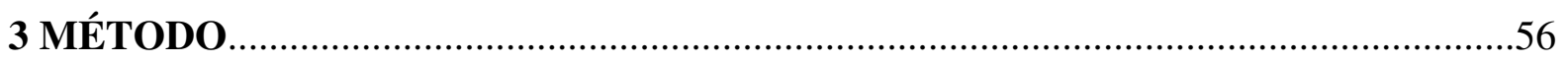

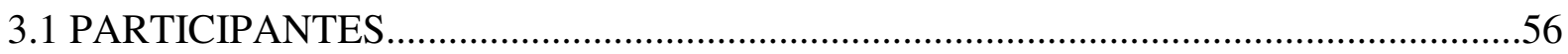

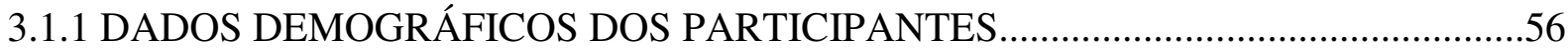

3.1.2 CRITÉRIOS PARA A SELEÇÃO DOS PARTICIPANTES......................................61

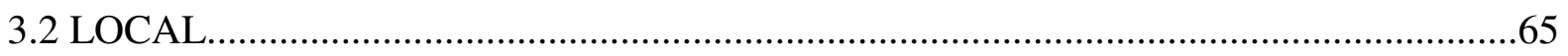

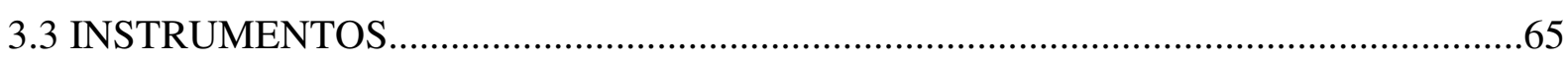

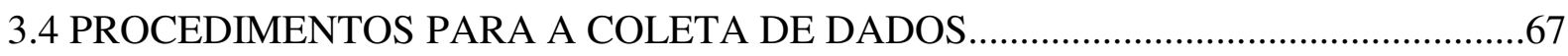

3.5 PROCEDIMENTOS PARA O TRATAMENTO E PARA A ANÁLISE DE DADOS....69

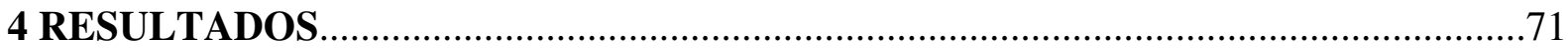

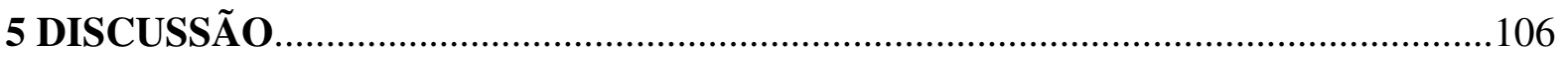

5.1 ANÁLISES DAS PRÁTICAS EDUCATIVAS MATERNAS........................................106

5.2 ANÁLISES FUNCIONAIS DAS INTERAÇÕES ENTRE MÃES E ADOLESCENTES...

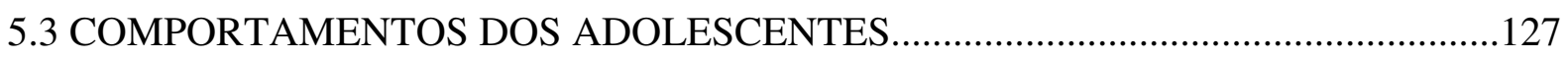

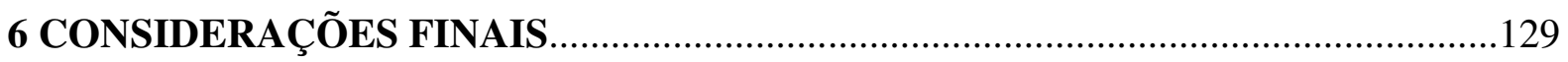

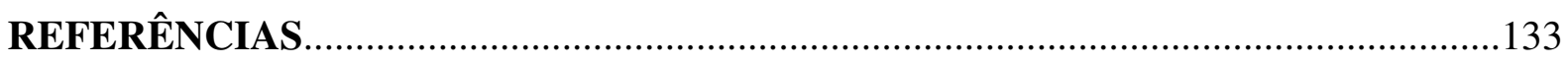

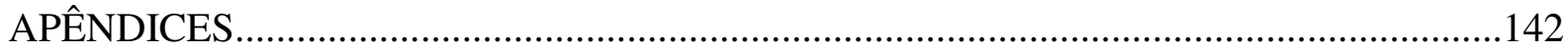

APÊNDICE A - Carta de apresentação do projeto de pesquisa à Secretaria da Educação do Estado do Paraná.

APÊNDICE B - Carta de aprovação do projeto emitida pelo Comitê de Ética em pesquisa da UNESP 
APÊNDICE C - Carta de autorização da pesquisa emitida pela Secretária de Educação do

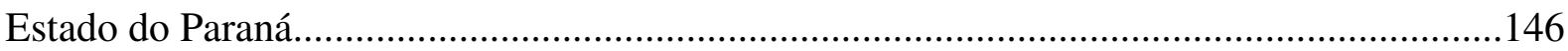

APÊNDICE D - Carta aos diretores para permissão da pesquisa........................................147

APÊNDICE E - Carta aos pais para autorização da participação dos filhos..........................148

APÊNDICE F - Carta de informação aos adolescentes sobre a pesquisa..............................149

APÊNDICE G - Termo de consentimento livre e esclarecido para as mães..........................150

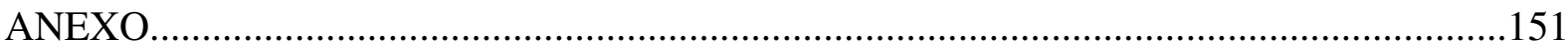

ANEXO A - Descrição das categorias de análise do Roteiro de Entrevista de Habilidades Sociais Educativas Parentais- RE-HSE-P (BOLSONI-SILVA, 2009). 


\section{INTRODUÇÃO}

As influências sobre o comportamento humano, em geral, são complexas e muitas vezes difíceis de serem detectadas (SKINNER, 1998). No caso de um adolescente, há diversas contingências que podem atuar sobre o seu comportamento, como o relacionamento entre pais e filhos, as relações entre pares, a escola, a mídia, as condições socioeconômicas e culturais, entre outras (GOMIDE, 2003). Dos fatores citados, a relação entre mães e adolescentes foi o tema escolhido para este trabalho. Para compreender essa relação, considera-se os apontamentos da literatura especializada sobre a influência que o comportamento parental exerce sobre os filhos e vice-versa (BAUMRIND, 1966; MACCOBY; MARTIN, 1983; PATTERSON; REID; DISHION, 1992; GOMIDE, 1998, 2003, 2006; BOLSONI-SILVA, 2000, 2003, 2008, 2009).

O panorama geral dos estudos sobre o relacionamento entre pais e filhos mostra que as pesquisas pioneiras (BAUMRIND, 1966; MACCOBY; MARTIN, 1983) classificavam as ações parentais em estilos amplos, relacionados a comportamentos emitidos pelos filhos. Os estudos mais recentes (GOMIDE, 2003, 2006; DISHION; MCMAHON, 1998; PATTERSON; REID; DISHION, 1992) investigam correlações mais detalhadas sobre a influência dos pais sobre os filhos e destes sobre aqueles. Essas pesquisas visam identificar e descrever minuciosamente as ações parentais e suas consequências sobre determinados comportamentos dos adolescentes.

Os estudos mencionados investigam, mais especificamente, que prática parental exerce influência sobre a aprendizagem, ou não, de que comportamento juvenil. Além disso, eles apontam para a importância que há na frequência e na magnitude do comportamento parental, já que esses aspectos podem afetar o desenvolvimento, ou não, de determinados comportamentos no adolescente (DISHION; MCMAHON, 1998; GOMIDE, 2003, 2006). A partir da investigação das práticas parentais utilizadas e da confluência delas, é possível, então, detectar famílias de risco social, ou não, em relação a problemas de comportamento de adolescentes (GOMIDE, 1998, 2003, 2004, 2006; PATTERSON; REID; DISHION, 1992).

Outra perspectiva de estudo, atual, aponta para a importância de se aprofundar os conhecimentos sobre a relação entre pais e filhos utilizando a análise funcional (SKINNER, 1998), buscando identificar como os comportamentos parentais e filiais se inter-relacionam (BOLSONI-SILVA, 2003, 2008, 2009). 
Baseado na teoria analítico-comportamental, junto à área de treinamento de habilidades sociais (DEL PRETTE; DEL PRETTE, 1999), Bolsoni-Silva (2003, 2008, 2009) propõe o estudo das Habilidades Sociais Educativas Parentais como uma variável a ser investigada na relação entre pais e filhos. A proposta da autora descreve de forma operacional e interativa as ações parentais, habilidosas, ou não, relacionadas aos comportamentos dos filhos, sejam eles habilidosos ou indicativos de problemas de comportamento.

Este estudo é o primeiro a utilizar a proposta de Habilidades Sociais Educativas Parentais, de Bolsoni-Silva (2003, 2008, 2009), aplicada à análise do comportamento na relação entre mães e filhos adolescentes, pois os trabalhos anteriores da autora (2000, 2003, 2008, 2009) são voltados ao público infantil. A presente pesquisa pretende comparar as habilidades sociais educativas de mães, cujos filhos demonstram a vivência de relações de risco ou não risco, o que pode ser motivo para o desenvolvimento de problemas de comportamento nos adolescentes. Pretende-se investigar também a presença ou a ausência de habilidades sociais e os problemas de comportamento dos adolescentes dos grupos de risco e não risco.

Os aspectos relevantes que estabelecem o problema desta pesquisa podem ser resumidos, então, nos seguintes itens: (a) apresentação das pesquisas que apontam para a influência das práticas parentais sobre o comportamento de adolescentes, isto é, exposição dos estudos que levam à compreensão da relação existente entre as práticas parentais e o comportamento de adolescentes; (b) identificação de problemas de comportamento relacionados às interações familiares e menção de alguns temas de interesse para o estudo da adolescência; (c) estudo dos estilos e das práticas parentais, com ênfase à proposta de práticas parentais de Gomide (2003, 2006), que investiga como pais influenciam o comportamento dos filhos e quais as consequências que essas práticas exercem sobre o comportamento dos adolescentes; (d) realização da análise funcional da relação entre pais e filhos, com base na análise do comportamento e no treino de habilidades sociais, conforme as contribuições de Bolsoni-Silva (2003, 2008, 2009). 


\subsection{AS PRÁTICAS PARENTAIS E O COMPORTAMENTO DE ADOLESCENTES}

A literatura especializada no relacionamento entre pais e filhos adolescentes associa as práticas parentais ao desenvolvimento de habilidades sociais ou a problemas de comportamento dos adolescentes (AVANCI, et al., 2007; BORAWSKI, et al., 2003; DICLEMENTE et. al., 2001; DISHION; MCMAHON, 1998; FLETCHER; STEINBERG; WILLIAMS-WHEELER, 2004; GOMIDE, 1998, 2003; HA et al., 2009; MCGUE et al., 2005; PACHECO; SILVEIRA; SCHNEIDER, 2008; PATTERSON; REID; DISHION, 1992; PETTIT et. al., 2001; PLUNKETT, 2007; REICHERT; WAGNER, 2007; REPPOLD et al, 2002; STATTIN; KERR, 2000; STEINBERG et al., 1994; TEIXEIRA; OLIVEIRA; WOTTRICH, 2006).

As habilidades sociais são definidas como comportamentos utilizados em interações sociais e, por isso, são indispensáveis à sobrevivência na sociedade. Essas habilidades trazem benefícios para o indivíduo e para as demais pessoas ao seu redor, além de minimizarem as perdas para o sujeito e seu grupo (DEL PRETTE; DEL PRETTE, 1999). As habilidades sociais são responsáveis pela aprendizagem de novos comportamentos, denominados prósociais, como a disponibilidade, a cooperação, a comunicação assertiva, a resolução de problemas e a empatia. Os comportamentos pró-sociais aumentam a probabilidade de se obter reforçadores ${ }^{1}$ que podem favorecer a aprendizagem de novos comportamentos relevantes ao repertório do indivíduo. Dessa forma, é possível identificar as contingências que influenciam o surgimento de um novo comportamento, como produto da aprendizagem de vários comportamentos sucessivos anteriores (ROSALES-RUIZ, 1997). Esse processo é denominado de salto comportamental, do inglês cusps (ROSALES-RUIZ, 1997).

Os problemas de comportamento podem, por outro lado, dificultar o desenvolvimento de novas habilidades sociais infanto-juvenis, porque limitam o acesso do jovem às contingências de reforço ${ }^{2}$ responsáveis pela aprendizagem. Segundo Bolsoni-Silva e Del Prette (2003), tanto as habilidades sociais quanto os problemas de comportamento devem ser analisados de modo funcional.

O motivo pelo qual os problemas de comportamento do adolescente estão associados aos comportamentos parentais está sendo investigado por diferentes estudos. Salvo, Silvares e

\footnotetext{
1 Reforçadores são estímulos que aumentam a probabilidade de emissão de determinado comportamento (SKINNER, 1998).

${ }^{2}$ As contingências são as relações comportamentais que apresentam interdependência entre si. As contingências de reforço possibilitam tanto a emissão de um novo comportamento quanto a sua manutenção.
} 
Toni (2005), por exemplo, apoiam a ideia de que a relação entre pais e filhos prediz o desenvolvimento de problemas de comportamento internalizantes e externalizantes nos adolescentes. Os comportamentos internalizantes ficam evidentes quando há retraimento, queixas somáticas, depressão e ansiedade patológica (ACHENBACK; EDELBROCK, 1979). Os externalizantes, por sua vez, são evidenciados por atos impulsivos, agressivos, desafiadores (frequentes em transtornos de agressividade), desafiadores-opositores, antissociais e pelo abuso de substâncias (ACHENBACK; EDELBROCK, 1979; BOLSONISILVA; DEL PRETTE, 2003). Os comportamentos antissociais trazem prejuízo social de caráter agressivo e desafiador (PACHECO et al., 2005).

Pré-adolescentes de onze a treze anos de idade participaram da pesquisa de Salvo, Silvares e Toni (2005), no qual foi comprovada a correlação entre as práticas educativas e os problemas de comportamento dos jovens. O estudo apontou a ausência de monitoria positiva materna como prenúncio de problemas de comportamentos externalizantes, como a agressividade, por exemplo. A presença da monitoria positiva materna foi correlacionada à sociabilidade do adolescente. A monitoria negativa materna, por outro lado, estava associada a problemas de atenção e problemas internalizantes, como a ansiedade e a depressão. A monitoria negativa materna, aliada à disciplina relaxada materna, antecipou problemas como a ansiedade e a depressão do filho. $\mathrm{O}$ estudo concluiu que as práticas educativas maternas influenciam o comportamento do adolescente e, dessas práticas, a monitoria positiva está relacionada à sociabilidade, e a negativa, aos problemas de comportamento.

No estudo citado, observou-se também que muitos fatores contribuíram para a formação dos estilos parentais e sua associação com o envolvimento de adolescentes em situações de risco para problemas de comportamento. Sendo assim, a monitoria parental parece ser especialmente importante nessa relação (BORAWSKI et al., 2003; DICLEMENTE et al., 2001; DISHION; MCMAHON, 1998; FLETCHER et al., 2004; GOMIDE, 2004, 2006; STATTIN; KERR, 2000; PETTI et al., 2001).

Um componente essencial da monitoria é o conhecimento das atividades que o adolescente exerce. Para conhecê-las, os pais precisam usar estratégias de comunicação, estabelecer regras e medir as consequências de se cumprir, ou não, tais regras de forma consistente. A monitoria envolve o conhecimento e a orientação das vivências do adolescente por meio de métodos não $\operatorname{coercitivos}^{3}$, mas que podem funcionar como uma medida

\footnotetext{
3 A coerção ocorre quando os comportamentos são controlados por reforço negativo ou punição (SIDMAN, 2001). O reforço negativo consiste num tipo de relação comportamental em que há o aumento da frequência de um comportamento operante na retirada de um estímulo consequente aversivo (SKINNER, 1998). A punição
} 
preventiva primária na redução ou diminuição de comportamentos de risco. Tais comportamentos parentais podem também ser estimulados como medida de intervenção entre jovens com repertório comportamental de risco instaurado (GOMIDE, 2003; DISHION; MCMAHON, 1998).

Diversos modelos teóricos mostram que as práticas parentais de risco são vinculadas a uma cadeia de causas que inicia com comportamentos desviantes na infância, levam à associação de pares desviantes e resultam no comportamento antissocial na adolescência (PATTERSON; REID; DISHION, 1992; GOMIDE, 2003, 2004, 2006; LONG; FOREHAND, 2003). Segundo Fletcher, Steinberg e Williams-Wheeler (2004), os adolescentes sob monitoria e controle parental efetivos são menos propensos a se envolver em problemas comportamentais, como o abuso de substâncias e a delinquência.

No estudo de Dishion e McMahon (1998) sobre práticas parentais voltadas aos adolescentes, os autores focam a descrição de determinadas ações parentais, como a motivação parental, a administração dos comportamentos e a qualidade da relação. A motivação parental representa o sistema de crenças e inclui normas, valores e objetivos dos pais, isto é, envolve os determinantes dos comportamentos parentais e o fato dos pais discriminarem, ou não, quais são suas metas educativas.

A administração de comportamentos requer dos pais atenção às consequências aplicadas aos comportamentos do filho, ou seja, requer que aqueles modelem positivamente ${ }^{4}$ o comportamento do jovem a partir de incentivos, elogios, feedbacks, auxílio, aplicação de limites e negociação. A qualidade da modelagem dá ao adolescente o sentimento de segurança, confiança e envolvimento dos pais e está diretamente relacionada à efetividade da monitoria, à motivação e à administração parental (DISHION; MCMAHON, 1998). Os autores destacam em seus estudos que as práticas parentais aplicadas ao adolescente devem considerar a idade do mesmo, a comunidade, o ambiente familiar, as variações ecológicas, a estrutura familiar (pais casados, separados ou solteiros) e as condições financeiras (GOMIDE, 2003, 2004; BOLSONI-SILVA, 2008, 2009; STANTTIN; KERR, 2000; PATTERSON; REID; DISHION, 1992; FLETCHER; STEINBERG; WILLIAMS-WHELLER, 2004).

consiste na diminuição ou eliminação da ocorrência de determinado comportamento após a adição de um estímulo aversivo (punição positiva) ou após a retirada de um estímulo não aversivo (punição negativa) (SKINNER, 1998).

${ }^{4}$ Modelar positivamente, do termo modelagem (SKINNER, 1998), é a expressão usada para designar a situação em que os pais ensinam os filhos com reforçadores diferenciais e gradativos. Em outras palavras, os pais podem ensinar novos comportamentos, reforçando alguns em detrimento de outros, e aos poucos aumentar a especificidade dos comportamentos que precisam ser reforçados. 
Borawski et al. (2003) destacam que a maioria das pesquisas tem se voltado para o estudo da dimensão monitoria parental. As autoras apontam para a necessidade de investigações acerca das demais variáveis, como a administração do comportamento, as cognições e a confiança parental, por serem componentes importantes na previsão de comportamentos de risco na adolescência. Elas investigaram também a relação entre a monitoria, a negociação do tempo em que os pais não estão com seus filhos e a percepção da confiança parental com os comportamentos de risco na adolescência. Como resultado, as autoras perceberam que a monitoria parental, definida como saber onde e com quem o filho está, quando utilizada sem outros comportamentos por parte dos pais, não é suficiente para a prevenção dos comportamentos de risco.

Os achados dessa pesquisa, realizada com 692 participantes de 15 anos, mostraram que deixar de negociar e conversar sobre as atividades do período em que os filhos não estão com os pais ou na escola pode aumentar ou acelerar a propensão para experimentar a vida sexual e usar substâncias (álcool, tabaco e maconha). Os jovens que conversam e negociam o tempo com os pais não deixam de ter experiências relacionadas à sexualidade, no entanto estão propensos a ter uma vida sexual mais tardia, a carregar e fazer o uso de preservativos e negar o sexo sem proteção (BORAWSKI, 2003).

Os resultados da pesquisa apresentada chamam a atenção para a importância do monitoramento aliado à negociação. Quando os pais monitoram seus filhos adolescentes usando a comunicação, criam oportunidades de aceitação das orientações e, dessa forma, o adolescente se prepara melhor para viver certas experiências naturais no desenvolvimento humano (BORAWSKI, 2003).

Na mesma direção, no que diz respeito ao comportamento de negociação e orientação da conduta do adolescente, Stattin e Kerr (2000) enfatizam a importância da comunicação positiva $^{5}$ entre pais e filhos para que a monitoria seja efetiva, isto é, seja o principal instrumento de prevenção contra problemas de comportamento.

When several aspects of parenting are examined together, the findings often suggest that parent-child communication is more beneficial than surveillance and control (STANTTIN; KERR, 2000, p. 1073).

Quando muitos aspectos das práticas educativas são examinados conjuntamente, os achados sugerem que a comunicação parental é mais benéfica que a vigilância e o controle (Trad. de SABBAG, Gabriela Mello).

\footnotetext{
${ }^{5}$ Comunicação positiva ocorre quando há predominantemente reforçadores positivos nas interações como, por exemplo, falar sem ofensas, ouvir atentamente o outro, orientar de forma compreensiva, discordar de forma assertiva.
} 
Os autores avaliaram o processo interacional entre mães, pais e filhos adolescentes, reconhecendo a reciprocidade e a bidirecionalidade da relação. Eles concluíram que é necessária a disciplina consistente, o controle ativo sobre os comportamentos do adolescente e a ação coerente ao comportamento do filho quando as regras são violadas, para que haja a efetividade dos limites. No entanto, isso somente é possível quando os pais e os filhos conseguem dialogar de forma aberta e quando os filhos confiam nos pais contando com espontaneidade sobre suas vidas, o que dificilmente ocorre quando estes controlam aqueles de forma punitiva ${ }^{6}$. A punição é uma forma de fazer com que o adolescente não se sinta à vontade para falar, pois dessa forma ele terá receio de ser criticado ou hostilizado (STANTTIN; KERR, 2000).

A consequência para a comunicação punitiva é o risco de problemas de comportamento no adolescente, já que ele deixa de conversar com os pais por receio de ser punido, o que aumenta as chances de envolvimento em situações de risco por falta de orientação (GOMIDE, 1998, 2003; STANTTIN; KERR, 2000). Além disso, esse adolescente pode vir a se aproximar de grupos considerados desviantes, pois eles funcionam como rede de apoio para ele (PATTERSON; REID; DISHION, 1992).

A coerção parental pode ocorrer por ameaças verbais de punição, humilhações, hostilidade ou mesmo por intrusão parental. Esta é denominada pelos autores de controle psicológico do filho, abuso psicológico ou, de modo geral, prática parental negativa (PETTIT et al., 2001; GOMIDE, 1998, 2003; DISHION; MCMAHON, 1998).

Dos estudos em foco, foi o de Pettit et al. (2001) que investigou os antecedentes comportamentais maternos e sua relação com os problemas de comportamento dos filhos no início da adolescência. Eles escolheram a monitoria materna e o controle psicológico para verificar a incidência de problemas comportamentais em dois momentos da vida dos participantes: entre 8 e 10 anos de idade e novamente entre 13 e 14 anos de idade.

Em relação à monitoria materna, ela inclui conversar, orientar, conhecer as atividades do filho e estabelecer limites. Em relação ao controle psicológico, por sua vez, ele inclui excesso de fiscalização e intrusão. Os resultados do estudo de Pettit et al. (2001) mostraram que a monitoria é associada à diminuição de problemas de comportamento, e o controle psicológico, ao aumento de problemas de conduta delinquentes nos filhos. Logo, a monitoria

\footnotetext{
${ }^{6}$ Controlar de forma punitiva significa restringir o adolescente a viver experiências enriquecedoras a partir de, por exemplo, críticas ofensivas, humilhações e ameaças. Esses comportamentos, ao invés de reforçarem novas habilidades do filho, punem.
} 
materna foi associada ao estilo parental autoritativo ${ }^{7}$, e o controle psicológico, ao estilo parental autoritário.

Os relatos que justificam o uso de controle psicológico por parte das mães decorreram do julgamento materno de que seus filhos têm problemas de comportamento externalizantes. Essas mães detectaram que seus filhos apresentam comportamentos agressivos, desafiadores e opositores como determinantes de suas próprias atuações controladoras.

As mães que utilizaram a severidade e a disciplina punitiva desde o início da infância de seus filhos estavam propensas à intrusão psicológica e à manipulação durante os anos iniciais da adolescência. É por isso que o controle psicológico foi associado a altos níveis de ansiedade, depressão e comportamento delinquente nos adolescentes. Já altos níveis de monitoria foram associados a baixos níveis de comportamento delinquente na infância avançada e na adolescência. A monitoria adequada é caracterizada pela relação de diálogo e interação positiva, contrária ao controle psicológico que não é percebido pelos filhos como monitoria, mas, sim, como intrusão. A ausência de monitoria materna foi associada mais fortemente aos problemas de comportamento delinquente do que aos problemas de ansiedade e depressão. Estes problemas foram previstos somente pelo controle psicológico e não pela monitoria (PETTIT et al, 2001).

Os estudos até então apresentados mostram a importância que a monitoria realizada a partir da comunicação positiva possui na prevenção de problemas de comportamento de adolescentes (PETTIT et al, 2001; GOMIDE, 1998, 2003; STANTTIN; KERR, 2000). O monitoramento é realizado a partir da orientação e não a partir dos comportamentos parentais intrusivos e hostis, presentes nas disciplinas autoritárias. Os comportamentos com tais características podem prejudicar a percepção dos filhos sobre os pais e sobre si mesmos, além de prejudicarem o desenvolvimento de sua autonomia e o cuidado com sua saúde. Destaca-se ainda que a percepção, a autonomia e os comportamentos protetores estão inter-relacionados.

Em relação à percepção que o adolescente tem sobre os pais e sobre si mesmo, tanto as práticas parentais quanto as mudanças de comportamento, naturais ao desenvolvimento humano, trazem modificações na relação entre pais e filhos (MCGUE et al., 2005; PLUNKETT et al., 2007). O aumento da frequência da expressão de sentimentos negativos por parte dos pais e dos filhos, assim como a desinibição do comportamento do adolescente

\footnotetext{
${ }^{7}$ Estilo parental autoritativo, termo desenvolvido por Baumrind (1966), significa que os pais se utilizam de contingências reforçadoras, como aceitação, expressão de afeto, orientação e aplicação de regras e limites. Já no estilo autoritário (BAUMRIND, 1966), há predominância de práticas coercitivas, aplicadas à educação do filho, e pouca expressão de afeto.
} 
podem provocar a tensão adicional da relação entre pais e filhos, o que, consequentemente, pode modificar a percepção dos filhos sobre seus pais e vice-versa (MCGUE et al., 2005).

Para a análise do comportamento, o estudo da percepção refere-se à análise dos comportamentos encobertos (SKINNER, 1998), os quais estão relacionados diretamente a eventos externos ao indivíduo. A percepção do adolescente é influenciada, nesse caso, pelas práticas parentais, pelos amigos, pela mídia, pela avaliação do seu próprio comportamento e também pelas mudanças fisiológicas (fator filogenético). A percepção dos pais sobre seus filhos também é influenciada pelo comportamento destes, pelas mudanças apresentadas e outros fatores antecedentes como a história de vida dos pais, as crenças parentais, a cultura e as condições socioeconômicas (BOLSONI-SILVA; MARTURANO, 2002).

Ao estudarem a percepção de adolescentes gêmeos de 11 aos 14 anos sobre seus pais, McGue et al. (2005) encontraram mudanças significativas de relacionamento que afetaram a percepção da qualidade da relação entre pais e filhos. Os conflitos, no entanto, aumentaram, e o envolvimento com os pais e a consideração por eles diminuiu.

Segundo Plunkett et al. (2007), a percepção do adolescente sobre os pais e sobre si mesmo está diretamente relacionado ao suporte parental e ao controle psicológico. Além disso, a percepção que o jovem tem de si e de sua autoestima emergem das interações com os pais. O adolescente toma consciência dele mesmo por meio da interação com pessoas que são significativas para ele, percebe como essas pessoas reagem em relação a ele, interpreta tais reações e internaliza as respostas que recebe dos outros. Portanto, o adolescente que nota a reação de seu pai e de sua mãe de forma amistosa, afetiva, encorajadora pode se perceber como importante, valioso, diminuindo o risco da depressão.

Essa proposta é coerente com os estudos de análise do comportamento, para a qual a autoestima do filho está diretamente associada aos estímulos externos aos quais ele está exposto, em especial a sua família, mas também em função de outras experiências sociais (GUILHARDI, 2002).

Em relação a esse assunto, Skinner (1974, p. 31) afirma que "Só quando o mundo privado de uma pessoa se torna importante para as demais é que ele se torna importante para ela própria”. Com isso ele quis dizer que as pessoas aprendem a se valorizar a partir do que aprendem em suas relações sociais, em especial na relação com os pais. Essa ideia recebe também o apoio de vários estudiosos da relação entre pais e filhos (BAUMRIND, 1966; MACCOBY; MARTIN, 1983; GOMIDE, 2003, 2004; BOLSONI-SILVA, 2003, 2008). Esses pesquisadores julgam de suma importância a valorização dos filhos por parte dos pais, os quais devem elogiar seus filhos, principalmente ao emitirem comportamentos pró-sociais. 
Consequentemente, quando buscam reforçar positivamente tais atitudes, aumentam a autoestima do filho e previnem problemas de comportamento.

Os resultados do estudo de Plunket et al. (2007) também mostraram que adolescentes, cujos pais oferecem pouco suporte e apoio, são mais vulneráveis à depressão quando se percebem menos valiosos. Assim também o controle psicológico pode levar ao humor depressivo, pois o adolescente sob influência de práticas parentais intrusivas sente-se desvalorizado. Entre essas práticas parentais punitivas estão o excesso de rigidez e o controle psicológico, que podem dificultar o surgimento de comportamentos independentes e autônomos no jovem (LUYCKX et al., 2007; SOENENS et al., 2005; REICHERT, WAGNER, 2007; PACHECO; TEIXEIRA; GOMES, 2008).

O estudo longitudinal de Luyckx et al. (2007) buscou avaliar quando o controle psicológico parental pode ter um impacto negativo sobre o desenvolvimento da autonomia do filho. Esse estudo foi realizado com 364 jovens com idade média de 18 anos na Bélgica. As análises do estudo longitudinal mostraram que quanto mais os jovens percebiam os pais como controladores maiores eram as dificuldades para tomar decisões e ter certeza sobre suas escolhas.

O controle parental excessivo foi associado ao comportamento do jovem de explorar e viver novas experiências de forma não consciente. Os pais que exercem controle psicológico, quando se deparam com um filho jovem que explora diferentes alternativas, ao invés daquelas propostas por eles, aumentam a intensidade do controle sobre o filho e o pressionam a tomar uma decisão imposta.

Desde o início da infância, quando se exige obediência suprema do filho, o provável resultado é muita hostilidade. Ela pode ser representada pela inobediência, pela resistência e por outros tipos de problemas, como os comportamentos internalizantes ou externalizantes (PATTERSON; REID; DISHION, 1992).

As práticas parentais coercitivas reduzem a probabilidade de reforçamento positivo ${ }^{8}$ do comportamento do jovem. Além disso, diminuem a sua variabilidade e enfraquecem as condutas, como tomar decisões e analisar as consequências do próprio comportamento, isto é, diminuem a autonomia do adolescente.

\footnotetext{
${ }^{8}$ A definição de reforçamento positivo, segundo a análise do comportamento (SKINNER, 1998), é relacional, pois envolve um conjunto de comportamentos, denominados operantes, que se mantêm por suas consequências. Estas aumentam a probabilidade de que as mesmas condutas se repitam também no futuro a partir de estímulos de reforço que trazem uma adição ao ambiente. Em outras palavras, dizemos que houve reforço positivo a partir do aumento da frequência de um comportamento operante e da adição de um estímulo ao ambiente.
} 
De acordo com Bolsoni-Silva (2003, 2008), Sidman (2001) e Gomide (2003, 2004), as práticas parentais estritamente punitivas não são estimuladoras do desenvolvimento e da ampliação do repertório comportamental do filho. Essas práticas aumentam a possibilidade de surgirem problemas de comportamento em função do déficit ${ }^{9}$ em habilidades sociais do filho. O jovem fica mais vulnerável a situações de risco, por isso pode se envolver com pares desviantes, isolar-se socialmente, usar drogas, praticar sexo sem proteção, entre outras (PATTERSON, REID, DISHION, 1992).

Um determinante do controle psicológico exercido pelos pais pode estar associado ao perfeccionismo, o que pode vir a afetar a autonomia do adolescente (SOENENS et al., 2005). Quando associado a níveis de exigência que permitirão uma boa adaptação do jovem, o perfeccionismo pode ser adaptativo. Já quando os pais tendem a levar padrões de exigência pessoal a cabo, mesmo que esses padrões provoquem consequências adversas nos filhos, esse perfeccionismo pode ser mal adaptativo.

Altos níveis de exigência por parte dos pais são muitas vezes seguidos pelos filhos mais pelo medo da falha do que pelo alcance da meta. Os pais perfeccionistas mal adaptados são muito críticos em sua própria autoavaliação. Eles exigem que as demais pessoas sigam os mesmos padrões irreais de desempenho. Esse tipo de controle psicológico sobre os filhos refere-se àquele em que os pais exercem quando focam primariamente as suas próprias necessidades psicológicas e seus problemas. Em função disso, eles agem de forma autoritária na sua relação com o filho.

A hipótese do estudo em questão leva a perceber que os pais perfeccionistas mal adaptados podem estar menos afinados com as necessidades e os comportamentos de seus filhos. É por isso que projetam neles seus padrões de exigência, provocando sentimentos de culpa quando suas expectativas não são alcançadas.

Os achados de Soenens et al. (2005) mostraram que os pais com perfeccionismo mal adaptado tendem a inibir a autonomia dos adolescentes. $\mathrm{O}$ resultado é coerente com o estudo de Gomide et al. (2005). Ela deparou-se com a monitoria negativa parental associada à depressão no adolescente.

A monitoria negativa citada anteriormente é semelhante ao controle psicológico parental. Ela é caracterizada pelo excesso de regras, fiscalizações e críticas que não são interessantes para estimular as habilidades do jovem. A monitoria negativa está relacionada ao

\footnotetext{
${ }^{9}$ Os déficits comportamentais referem-se à ausência ou à baixa frequência, magnitude e intensidade de uma resposta, o que também pode ser considerado impróprio de acordo com a demanda situacional (ROSS, 1979; GELFAND; HARTMAN, 1975).
} 
funcionamento dos pais e traz consequências adversas ao adolescente, entre as quais está a depressão (GOMIDE et al., 2005).

$\mathrm{O}$ adolescente que é fiscalizado e criticado severamente por suas iniciativas e decisões pode ter sua autoestima diminuída e apresentar dificuldade para tomar decisões no futuro. Isso provoca a inibição do repertório do adolescente, isto é, diminui sua autonomia. Consequentemente, a depressão, caracterizada pela perda de reforçadores, é o repertório comportamental de baixa frequência e variabilidade de respostas comportamentais. (FERSTER; CULBERSTON; PERROT-BOREN, 1977). No caso do adolescente sob influência de fiscalização parental ou monitoria negativa, ele pode deixar de emitir comportamentos por falta de um repertório reforçado, diminuindo suas oportunidades de aprendizagem.

A relação entre estilos parentais e autonomia do adolescente também foi investigada por Reichert e Wagner (2007). O estudo foi realizado no Brasil com 168 jovens, de 14 e 15 anos, estudantes de Porto Alegre. As autoras utilizaram a definição de autonomia que consiste na habilidade para pensar, sentir, tomar decisões e agir por conta própria. O estudo concluiu que, na medida em que as mães agem de forma mais autoritária e menos afetuosa, os adolescentes encontram maiores dificuldades para tomar decisões por conta própria, diminuindo a sua autonomia funcional.

No estudo em questão, as autoras apontam três níveis de autonomia: a atitudinal ou cognitiva, a funcional ou condutual e a emocional. A atitudinal está relacionada às habilidades cognitivas para desenvolver metas e possibilidades de escolhas de forma analítica. A funcional refere-se ao controle de si, à capacidade para tomar decisões e cuidar dos próprios assuntos sem a ajuda dos pais. A emocional, por sua vez, envolve a confiança do jovem em suas escolhas independente dos pais e amigos.

O estudo mostrou que os estilos parentais autoritários não são estimuladores da autonomia do jovem e que a autonomia é uma habilidade a ser mais estimulada no adolescente. Os estudos analítico-comportamentais (SIDMAN, 2001; GOMIDE, 2003; BOLSONI-SILVA, 2003, 2008) apoiam essa ideia e revelam que as habilidades são promovidas em especial sob o efeito de contingências de reforço predominantemente positivas que estão relacionadas ao estilo parental autoritativo de Baumrind (1966).

Para Pacheco, Silveira e Schneider (2008), a educação do adolescente exige dos pais habilidades adaptativas devido às mudanças dessa fase da vida, em especial àquelas relacionadas à habilidade de autonomia. Como uma das tarefas no desenvolvimento do adolescente é conquistar a autonomia, que envolve a tomada de decisão, a pesquisa 
desenvolvida pelas autoras buscou relacionar os tipos de estilo parental materno e o nível de autonomia do adolescente sob ponto de vista de jovens entre 15 e 19 anos.

Os resultados apontaram para a responsividade materna e paterna associada ao envolvimento positivo com o adolescente, à aceitação incondicional, à sensibilidade em relação aos sentimentos do filho, à aceitação da autonomia e à divisão na tomada de decisão. Todas essas características são positivas e estimulam o desenvolvimento da autonomia (PACHECO; SILVEIRA; SCHNEIDER, 2008). Os resultados são condizentes com os estudos de Baumrind (1966) e também com as pesquisas analítico-comportamentais que apoiam as práticas parentais baseadas no reforçamento positivo (estilo autoritativo). Este reforçamento estimula as habilidades sociais (BOLSONI-SILVA, 2003, 2008), entre as quais se encontra a habilidade de tomar decisões (DEL PRETTE; DEL PRETTE, 2001).

Outras pesquisas (AVANCI et al., 2007; DICLEMENTE et al., 2001; ROMER et al., 1997) também mostram que a saúde dos adolescentes e seus comportamentos de autocuidado estão relacionados às práticas parentais. Nesse sentido, a monitoria é um importante componente na prevenção de comportamentos de risco à saúde na adolescência (DICLEMENTE et al., 2001; ROMER et al., 1997), assim como o controle psicológico também é um fator de risco para a saúde do adolescente (AVANCI et al., 2007).

O estudo brasileiro desenvolvido por Avanci et al. (2007) buscou investigar os problemas de saúde mental em adolescentes relacionados ao controle psicológico parental. Fatores individuais, sociais e familiares, associados ao desenvolvimento de transtornos psiquiátricos menores na adolescência, foram identificados. Entre esses fatores encontram-se sintomas psicossomáticos, como dores de cabeça, má digestão e sensações desagradáveis; sintomas de depressão, como tristeza, choro frequente, falta de apetite, perda de interesse, sentimento de inutilidade, ideia de suicídio, cansaço, dificuldade para pensar com clareza e para realizar atividades diárias; sintomas de ansiedade, como dormir mal, assustar-se com facilidade, tremores, nervosismo, tensão, agitação, dificuldade para tomar decisões e dificuldade escolar.

Os estudiosos encontraram a prevalência de 29,4\% dos transtornos psiquiátricos em adolescentes que, na avaliação da esfera familiar, demonstraram que o abuso psicológico foi o fator que mais esteve associado ao desenvolvimento de transtornos psiquiátricos menores. $\mathrm{O}$ abuso psicológico foi investigado a partir de situações como estas: ser humilhado pelos pais ou responsáveis, ter suas qualidades reduzidas por pessoas significativas, sofrer desvalorização de suas capacidades, vontades e emoções, além de padecer por cobrança excessiva. Os autores mostraram que as consequências que surgiram das práticas abusivas 
prejudicaram o desenvolvimento dos processos psicológicos básicos, como a autoestima, a autodeterminação e a capacidade de resiliência, o que, consequentemente, pode resultar em riscos para o desenvolvimento social do adolescente na vida adulta (AVANCI et al., 2007).

O estudo realizado por DiClemente et al. (2001) mostra que as ameaças à saúde do adolescente são primariamente consequências de seus próprios comportamentos de risco, os quais são influenciados pelas práticas parentais. Os autores (DICLEMENTE et al., 2001) investigaram a relação entre a percepção de pouca monitoria parental de 522 adolescentes entre 14 e 18 anos, do sexo feminino, e a associação entre infecção por doenças sexualmente transmissíveis - DSTs -, comportamentos sexuais de risco - ter vários parceiros -, uso de maconha, consumo de álcool, comportamento antissocial e violência.

As adolescentes que relataram ter recebido menos monitoria parental foram as que declararam ter usado menos preservativos durante seus atos sexuais recentes. Entre elas havia também as que não usaram nenhum tipo de contraceptivo durante as últimas cinco relações sexuais (DICLEMENTE et al., 2001).

A percepção de que as adolescentes receberam menos monitoria parental foi associada com frequência aos relatos de múltiplos parceiros sexuais nos últimos seis meses e à crença de que os parceiros tinham outras parceiras sexuais concorrentes. O uso da maconha no passado e atualmente também foi associado à percepção de pouca monitoria parental. As adolescentes que perceberam ter recebido menos monitoria parental também foram as que mais relataram ter sido detidas pela polícia. Além disso, aquelas que reportaram à menor monitoria parental foram as que mais receberam confirmação de que tinham uma doença sexualmente transmissível - DST (DICLEMENTE et al., 2001).

Os achados dessa pesquisa confirmam, portanto, a prevalência de comportamentos de risco entre adolescentes com menos monitoria parental (DICLEMENTE et al., 2001). O estudo de Romer et al. (1997) também apoia os resultados daquele estudo. Ambos afirmam que, apesar dos comportamentos sexuais de risco aumentarem com o avançar da idade, os adolescentes que foram muito bem supervisionados e monitorados pelos pais apresentaram comportamentos preventivos. Entre eles está o início tardio da vida sexual e o uso da camisinha, ao contrário dos jovens menos monitorados.

De modo geral, os estudos acima citados, que buscam relacionar as ações parentais ao comportamento do adolescente, são unânimes quanto à importância da monitoria parental na prevenção de problemas de comportamento (SALVO; SILVARES; TONI, 2005; BORAWSKI et al., 2003; DICLEMENTE et al., 2001; DISHION; MCMAHON, 1998; FLETCHER et al., 2004; GOMIDE, 2003, 2004, 2006; STATTIN; KERR, 2000; PETTI et 
$a l .$, 2001). Eles são unânimes também ao mostrarem os benefícios que a comunicação aberta, não punitiva, oferece. A comunicação é vista, por isso, como uma forma saudável de controle do comportamento do adolescente (STATTIN; KERR, 2000; PETTIT et al, 2001).

Além das informações apresentadas, os estudos confirmam também a relação entre o suporte parental e as melhorias da percepção do adolescente sobre seus pais e sobre si mesmo (MCGUE et al., 2005; PLUNKET et al., 2007). As pesquisas mostraram que aqueles pais que utilizaram práticas autoritárias enfrentaram dificuldades associadas ao desenvolvimento da autonomia do adolescente (LUYCKX et al., 2007; SOENENS et al.,2005; REICHERT; WAGNER, 2007; PACHECO; SILVEIRA; SCHNEIDER, 2008). Os estudos apontaram ainda que o excesso de práticas coercitivas gerou problemas de saúde nos adolescentes (AVANCI et al., 2007; DICLEMENTE et al., 2001; ROMER et al., 1997).

Fora o diagnóstico de que as práticas parentais estão associadas aos comportamentos do adolescente, sejam eles habilidosos ou problemáticos, faz-se necessária a descrição mais acurada do que são os estilos e as práticas parentais. É importante mostrar também quais as consequências de determinadas práticas ou estilos parentais sobre o comportamento dos filhos. 


\subsection{ESTILOS E PRÁTICAS PARENTAIS}

A área de estilos parentais vem sendo pesquisada por autores internacionais (BAUMRIND, 1966, 1996; MACCOBY; MARTIN, 1983; PATTERSON; REID; DISHION, 1992; STANTIN; KERR, 2000; PETTI et al., 2001; FLETCHER et al., 2004; BORAWSKI et al., 2003; MCGUE et al., 2005; PLUNKETT et al., 2007; LUYCKX et al., 2007; SOENENS et al., 2005; HA et al., 2009; SHELTON; HAROLD, 2008) e nacionais (GOMIDE, 2003, 2004, 2006; BOLSONI-SILVA, 2002, 2003, 2008, 2009; SALVO; SILVARES; TONI, 2005; REPPOLD et al., 2002; CIA; PAMPLIN; DEL PRETTE, 2006; BOLSONI-SILVA; MARTURANO, 2002; TEIXEIRA; OLIVEIRA; WOTTRICH, 2006; AVANCI et al., 2007). Os estudos sobre as relações familiares têm se voltado para a identificação e a descrição das crenças e dos valores parentais no subsídio das ações, das práticas educativas e dos estilos como um conjunto de atitudes voltadas para os filhos (REPPOLD et al., 2002).

As publicações científicas pioneiras sobre estilos parentais foram realizadas por Baumrind (1966, 1996). Ela desenvolveu o primeiro sistema de categorização e classificação dos estilos parentais a partir de características do comportamento paterno e materno, bem como os efeitos sobre o comportamento dos filhos. De acordo com o protótipo de controle parental de Baumrind (1966), os estilos são classificados em autoritário, autoritativo e permissivo.

Os pais considerados autoritários são aqueles que avaliam e controlam o comportamento do filho de forma predominantemente coercitiva e punitiva. Eles privilegiam o excesso de regras, apresentam crenças e normas rígidas e inquestionáveis, restringindo o desenvolvimento da autonomia do adolescente. Os pais autoritativos, ao mesmo tempo em que se mostram afetivos e apoiam seu filho emocionalmente, conseguem estabelecer regras e limites apropriados à fase de desenvolvimento do filho, apresentam expectativas razoáveis e comunicam-se estimulando a independência. Os pais permissivos são descritos como não punitivos, calorosos, mas que não estabelecem regras e limites necessários para o filho. Eles o deixam livre para agir como quiser e para tomar decisões para as quais ainda não possui maturidade (BAUMRIND, 1966).

Em meados dos anos 80, Maccoby e Martin (1983), influenciados pelos estudos de Baumrind (1966), propuseram a tipologia de estilos parentais baseada em duas dimensões: responsividade e exigência. A responsividade foi definida como a transmissão simultânea de afeto, comunicação positiva e suporte emocional ao filho. A exigência, por sua vez, envolve 
atitudes de supervisão e controle do comportamento da criança, além do estabelecimento de regras e limites.

A partir do cruzamento das duas dimensões, Maccoby e Martin (1983) ampliaram o rol de estilos elaborados por Baumrind (1966). Adicionaram a negligência, além do autoritário, autoritativo e indulgente (permissivo). O estilo autoritário, como proposto por Baumrind (1966), apresenta altos índices de exigência e baixos de responsividade, isto é, controla demasiadamente o comportamento da criança e não oferece suporte emocional. $\mathrm{O}$ estilo autoritativo é composto por altos níveis de responsividade e exigência, além de ser afetivo e disciplinador. Quanto ao estilo autoritativo, Maccoby e Martin (1983) reafirmam as idéias propostas por Baumrind (1966) de que as famílias autoritativas conseguem modelar o comportamento dos filhos de forma disciplinadora, mas não intrusiva, ao mesmo tempo em que os pais estimulam a autonomia do filho através do respeito pelas opiniões, decisões e interesses da criança, considerando a sua individualidade (REPPOLD et al., 2002).

O estilo negligente, proposto por Maccoby e Martin (1983), não apresenta nem altos índices de responsividade nem de exigência. Esse estilo não está atento às necessidades básicas da criança. Pais negligentes são pouco envolvidos na criação do filho, não demonstram interesse pelas atividades, pela vida da criança e nem afeto (REPPOLD et al., 2002). O estilo indulgente é aquele em que os pais manifestam alta frequência de responsividade e baixa de exigência, como fazem os pais permissivos do modelo proposto por Baumrind (1966).

A consistência do modelo de estilo parental, proposto por Baumrind (1966), trouxe uma oportunidade para o desenvolvimento de diversas outras pesquisas atuais que seguem a mesma perspectiva. $\mathrm{O}$ estilo de Baumrind contribuiu também com outros estudos que buscam a descrição minuciosa das práticas parentais e suas consequências sobre o comportamento dos filhos (GOMIDE, 1998, 2003, 2006; PATTERSON; REID; DISHION, 1992; BOLSONISILVA, 2003, 2008, 2009).

O estudo de Gomide (2003, 2004, 2006), também aborda os estilos parentais, mas diferentemente dos modelos apresentados até então, busca descrever operacionalmente as práticas parentais e, a partir daí, a identificação de suas combinações que culminarão em estilos. A autora elegeu determinadas ações parentais, organizou-as e as estruturou sob a classificação de sete práticas parentais. A proposta da autora apresenta a descrição dos comportamentos presentes em cada prática parental, bem como as possíveis consequências na relação entre pais e filhos e a probabilidade de que o adolescente desenvolva ou não 
problemas de comportamento. Essa probabilidade pode ser medida a partir da detecção da frequência e do uso de determinadas práticas em detrimento de outras.

A proposição de Gomide (1998, 2003, 2006) busca relacionar quais práticas parentais podem exercer influência sobre o desenvolvimento de problemas de comportamento no adolescente, em especial as que oferecem risco de comportamento antissocial. Para tanto a autora elegeu sete práticas educativas adotadas pelos pais, e a partir da frequência e intensidade de uso dessas práticas, obtém-se o estilo de risco ou não risco para problemas de comportamento $^{10}$. As práticas educativas foram classificadas como estimuladoras de comportamentos pró-sociais dos filhos, denominadas práticas positivas (monitoria positiva e comportamento moral), e aquelas que possibilitam a ocorrência de problemas de comportamento são as práticas negativas (disciplina relaxada, punição inconsistente, monitoria negativa, abuso físico e negligência). Considerando-se a frequência e a intensidade com que os pais utilizam as estratégias educativas, essas práticas poderão influenciar tanto no desenvolvimento de condutas pró-sociais quanto nas antissociais.

O comportamento antissocial é definido por Gomide (2003) como aquele prejudicial a si ou às demais pessoas. Como exemplo de transgressão social tem-se mentiras, atos de vandalismo, uso de substâncias ilícitas, comportamento agressivo e delitos leves ou graves. Já o comportamento pró-social envolve as habilidades sociais empáticas como comportamento altruísta, solidário e generoso (PRUST; GOMIDE, 2007).

Entre as práticas positivas, os pais que fazem uso da monitoria positiva estabelecem regras adequadas, demonstram carinho e afeição por seus filhos, sabem em quais momentos devem estar atentos e estabelecer limites aos comportamentos emitidos pelos filhos, distribuem privilégios de forma apropriada, acompanham e supervisionam as atividades escolares e o lazer demonstrando confiar no adolescente (GOMIDE, 2003, 2004, 2006). A autora apoia a definição de monitoria proposta por Dishion e McMahon (1998) e Snyder e Patterson (1987). Segundo Gomide (2004), os pais devem orientar os adolescentes sobre que locais podem frequentar, quais os momentos adequados para sair de casa, qual o momento em que devem retornar aos seus lares e quais as diferentes consequências para o cumprimento ou o não cumprimento das regras estabelecidas. Esses métodos se modificam de acordo com a

\footnotetext{
${ }^{10}$ No estudo original de Gomide (2003, 2006), a autora utiliza o termo antissocial. No presente estudo, optou-se pela expressão problemas de comportamento com base em Bolsoni-Silva e Del Prette (2003). Estes definem o comportamento como funcional e o relacionam às contingências de surgimento e à manutenção dos problemas. Esses problemas poderão acarretar déficits e/ou excessos comportamentais que dificultam o acesso da criança a novas contingências de reforçamento e a aquisição de repertórios relevantes de aprendizagem. Rosales-Ruiz e Baer (1997), que definem esses repertórios como saltos (cusps), referem-se às mudanças comportamentais que ocorrem no decorrer do processo de desenvolvimento como uma consequência da interação organismo-ambiente.
} 
etapa de desenvolvimento do filho, mas a função é sempre a mesma: facilitar o conhecimento dos pais sobre as atividades dos jovens, orientá-los e também comunicar o interesse dos pais pela vida do adolescente (GOMIDE, 2003, 2004, 2006).

Gomide (2003, 2004) destaca que é importante para os pais estimularem a conversação com os filhos através da audiência compreensiva, da demonstração de interesse pelas atividades e opiniões dos filhos, concomitantemente com a demonstração de afeto e confiança no filho. A monitoria parental inclui tanto a supervisão do jovem por um pai e/ou responsável quanto à comunicação entre pais e filhos, como propõem Stattin e Kerr (2000).

A monitoria positiva, como o próprio termo relata, é voltada para os aspectos positivos do comportamento do adolescente. Dessa forma possibilita-se a modelagem ${ }^{11}$ do comportamento pró-social dos adolescentes, predominantemente através do reforçamento positivo. A punição da monitoria positiva apresenta o intuito educativo de diminuição dos comportamentos problemáticos e não pretende ocasionar reações emocionais intensas geradas pela punição excessiva, mas, sim, pretende levar à compreensão de que determinados comportamentos trazem prejuízos para o jovem e para seu meio social. A orientação inicial pode ser esta: apontar para o adolescente qual comportamento foi inadequado, estimular a reflexão das consequências daquele comportamento para ele e para as pessoas ao seu redor, solicitar que o adolescente pense em alternativas para reparação dos danos e sua aplicação. Esses procedimentos possibilitam ao adolescente a aceitação de seus erros, a manutenção da sua auto-estima e o desenvolvimento do comportamento de solução de problemas, aspectos inibidores de problemas de comportamento (GOMIDE, 2004).

A prática educativa positiva, denominada comportamento moral, propõe que, pela modelação $^{12}$ (BANDURA, 1979) e modelagem, os pais transmitam valores como justiça, responsabilidade, apreciação do trabalho, generosidade, distinção entre o certo e o errado, reconhecimento e reparação dos próprios erros. Por meio da observação do comportamento parental e da vivência em relação aos comportamentos morais emitidos por seus pais, os filhos poderão aprender a se comportar de forma empática (GOMIDE, 2003, 2004, 2006). Para o desenvolvimento da empatia na criança, os pais devem aproveitar situações para que seus filhos aprendam. Nesse sentido, Hoffman (1994) considera essencial que os pais ofertem segurança e oportunidades de considerar as necessidades e o bem estar alheio, estimulando o

\footnotetext{
11 Moreira e Medeiros (2007) citam que os comportamentos novos que se aprende surgem a partir de comportamentos já existentes. Com a modelagem, os pais reforçam diferencialmente comportamentos emitidos pelos filhos a partir de aproximações sucessivas do comportamento-alvo.

${ }^{12} \mathrm{O}$ modelo de aprendizagem social desenvolvido por Bandura (1979) propõe a aprendizagem por modelação advinda da observação de outros modelos de comportamentos.
} 
desenvolvimento da empatia no filho, ou seja, a capacidade de colocar-se no lugar do outro para compreender as razões da outra pessoa. Eis, portanto, um fator inibidor de problemas de comportamento.

Os pais que apresentam comportamento moral possibilitam o desenvolvimento de sentimentos de empatia, vergonha e culpa (não excessivos). Esses pais auxiliam os filhos a discriminarem aqueles comportamentos que trazem prejuízos a si e ao outro e a evitá-los, buscando assim ensinar a reparar os danos advindos de comportamentos indesejáveis (GOMIDE, 2004).

Loos, Ferreira e Vasconcelos (1999) apontaram para um papel fundamental dos pais, o de apresentar desde cedo as consequências aos atos transgressores dos filhos. Tal ação parental possibilita o desenvolvimento de sentimentos de culpa após as transgressões, o que indica o desenvolvimento do comportamento moral.

Gomide (2004) também afirma que os pais devem permitir que os filhos percebam as consequências negativas de seus atos, além de incentivá-los a refletir sobre as mesmas para que não venham a cometê-las novamente. É necessário também que os pais ajudem seus filhos a repararem os danos causados pelos atos inadequados, permitindo a formação dos valores morais e o desenvolvimento da empatia. Para Falcone (2000) a empatia é uma habilidade social composta por capacidade acurada de compreensão da perspectiva e dos sentimentos do outro, sentimentos de compaixão e preocupação com a outra pessoa e manifestações verbais ou não verbais de compreensão dos estados internos do outro.

Quando os pais não cumprem as regras estabelecidas com seus filhos, estão adotando a prática negativa de disciplina relaxada que consiste na "quebra" dos acordos préestabelecidos anteriormente. Segundo Gomide (2004), na disciplina relaxada, os pais impõem certas regras aos filhos, os ameaçam caso não as cumpram, mas, ao se confrontarem com os comportamentos opositores de seus filhos "quebram" o pacto combinado, omitindo-se. Pesquisadores que investigam as influências sociais sobre o desenvolvimento de problemas de comportamento argumentam que as crianças com comportamentos agressivos e opositores, criadas em ambientes em que as práticas parentais são inconsistentes, estão em situação de risco para o desenvolvimento de comportamentos infratores durante a adolescência (PATTERSON; REID; DISHION, 1992).

Quando os pais punem ou reforçam atitudes de seus filhos em função de seu bom ou mau humor, estão utilizando a punição inconsistente (GOMIDE, 2003). Ela se baseia na educação realizada a partir das emoções parentais e não pelas manifestações de comportamento do adolescente. Em consequência, o filho aprende a discriminar o estado de 
humor dos pais como estímulo antecedente para a emissão, ou não, de determinados comportamentos, dificultando a aprendizagem da discriminação de qual comportamento é certo e qual é errado. Para a análise do comportamento, a convenção social do que é certo e do que é errado geralmente refere-se, respectivamente, a reforços e punições de comportamento (BAUM, 1999).

No caso dos filhos, eles não são estimulados a discriminar quais comportamentos devem ser mantidos e quais eliminados de seu repertório. Para Gomide (2004), tal prática desencadeia enorme instabilidade emocional nos filhos, porque não sabem que comportamentos devem usar para agradar os pais e as pessoas de seu convívio social, o que gera ansiedade e agressividade. Em consequência, aumenta a probabilidade dos pais perderem a autoridade e a confiança de seus filhos e destes serem rejeitados nas relações entre pares, pelo fato de não saberem como se comportar nos ambientes sociais.

A monitoria negativa ou estressante ocorre quando os pais fiscalizam e vigiam seus filhos a partir da alta frequência de instruções repetitivas, criando, dessa forma, um ambiente familiar estressante e hostil (GOMIDE, 2003). Os pais, ao agirem com desconfiança e fiscalização (punitiva), ensinam seus filhos a agir da mesma maneira com as demais pessoas. Além disso, quando promovem um ambiente punitivo, transmitem a mensagem de que seus filhos não possuem habilidades suficientes para enfrentar as situações de suas vidas. Esse processo restringe o desenvolvimento das habilidades sociais dos filhos, tornando-os mais dependentes, ao mesmo tempo que estimula comportamentos de fuga e esquiva na sua relação com os pais.

Pettit et al. (2001) diferenciam o controle comportamental do controle psicológico. O comportamental diz respeito às ações educativas de orientação do comportamento do filho, como, por exemplo, a aplicação de limites. E o psicológico é realizado a partir da manipulação emocional e dos esforços parentais para impedir que o filho tome decisões por conta própria, o que inibe e/ou impede o desenvolvimento de autonomia dele, já que ele se mantém emocionalmente dependente de seus pais. Os pais, dessa forma, dificultam o desenvolvimento da autoconfiança do adolescente e contribuem para o desenvolvimento de sentimentos de angústia e inadequação. Sobre o assunto, como destacam Patterson, Reid e Dishion (1992), os modelos de controle psicológico parental trazem consequências negativas aos jovens, como a união a pares antissociais e a busca de aceitação para suas ideias e ações.

O abuso físico (GOMIDE, 2003, 2004) ocorre quando os pais utilizam punições corporais intensas e/ou frequentes, o que representa um ato de mau-trato ao filho. Gomide (2003) distingue a punição corporal de abuso físico. Aquela é uma ação causada por força 
física cujo objetivo é punir um comportamento infantil, e este, o abuso físico, caracteriza-se por atos que machucam o filho através da aplicação de força física intensa e/ou associada a palavras humilhantes e demonstração de raiva, atingindo o ser e não o comportamento do filho. Ambas são práticas punitivas desaconselhadas por Gomide (2003, p. 32): “A punição corporal e o abuso físico são dois pontos em contínuo, sendo que se a punição corporal for administrada muito severa ou freqüentemente, ela atravessa para a linha do abuso físico". A autora atenta, por isso, para os riscos de se utilizar a punição física e esta acabar se tornando abusiva e prejudicial ao desenvolvimento saudável do filho.

A negligência ocorre quando os pais não estão atentos às necessidades de seus filhos, ausentam-se das responsabilidades, omitem-se de auxiliarem seus filhos ou simplesmente quando há interação familiar sem afeto, sem amor (GOMIDE, 2004). Ela pode ocorrer também em vários níveis e, dependendo desse nível, pode ser difícil a detecção.

Há casos em que os pais presenteiam seus filhos, contratam profissionais para lhes dar atenção, escolhem boas escolas, mas deixam de lado a interação afetiva e a comunicação, provocando a situação caracterizada como negligência afetiva. Há outros casos em que os pais nem cuidam do bem-estar físico dos filhos nem os orientam quanto à alimentação, higiene e estudos. Tanto a negligência quanto o abuso físico e o psicológico são consideradas práticas abusivas, de modo que frequentemente são associadas a problemas de comportamento mais severos em adolescentes, como a agressividade e a delinquência (GOMIDE, 2003, 2004, 2006).

Os estudos de Gomide $(2003,2006)$ são importantes por possibilitarem a identificação dos fatores de risco ou não risco para problemas de comportamento em adolescentes a partir das práticas parentais. Em outras palavras, esses estudos avaliam se as práticas parentais maternas e paternas e, do ponto de vista do adolescente, possibilitam a ocorrência de problemas em seu comportamento. Nesse sentido, a proposta da autora trouxe avanços consideráveis, pois facilitou a identificação de famílias cujas práticas parentais são de risco, ou não, para o desenvolvimento de problemas de comportamento nos filhos.

Com intuito de investigar mais do que a influência das práticas parentais sobre o comportamento do adolescente, como apresentado até o momento, os estudos atuais também buscam identificar as análises funcionais das relações entre pais e filhos (BOLSONI-SILVA, 2003, 2008, 2009). 


\subsection{AS CONTRIBUIÇÕES DA ANÁLISE DO COMPORTAMENTO PARA A RELAÇÃO ENTRE PAIS E FILHOS}

Com a intenção de aprofundar a análise funcional da relação entre pais e filhos, BolsoniSilva $(2002,2003,2008,2009)$ desenvolveu estudos sobre as Habilidades Sociais Educativas Parentais - HSE-P - que conceituou como práticas parentais voltadas à estimulação das habilidades sociais do filho (BOLSONI-SILVA, 2003; BOLSONI-SILVA; MARTURANO, 2002). A proposta baseia-se na teoria behaviorista radical (SKINNER, 1998) e na área de treinamento em habilidades sociais (DEL PRETTE; DEL PRETTE, 1999).

O behaviorismo radical, ou a análise do comportamento, considera o comportamento humano como um conjunto de interações entre o organismo e o seu ambiente, determinadas por fatores filogenéticos, ontogenéticos e culturais. A filogênese diz respeito às interações determinadas por herança genética, a ontogênese refere-se às interações determinadas por variáveis presentes na história de aprendizagem do indivíduo e a cultura envolve determinadas práticas sociais. Os três fatores determinantes do comportamento humano estão sob efeito da seleção por consequências (SKINNER, 1981).

Para Skinner (1998), o estudo do comportamento envolve a investigação e a descrição das relações funcionais e não somente a busca da causa e do efeito. Para o behaviorismo radical, as condições ou eventos que afetam o comportamento, de forma demonstrável, devem ser considerados, bem como os acontecimentos do mundo privado. Os sentimentos e pensamentos não podem ser negligenciados como fonte de informação, mas devem ser examinados com cautela, questionando a sua natureza e a fidedignidade (SKINNER, 1974). Buscar a explicação do comportamento no interior do organismo é incompleto e pode dificultar a detecção das variáveis que estão no ambiente imediato e na história ambiental. Segundo o autor (1998, p. 33), "Estas variáveis independentes são de várias espécies e suas relações com o comportamento são quase sempre sutis e complexas, mas não se pode esperar uma explicação adequada do comportamento sem analisá-las".

O comportamento humano advém de um encadeamento composto por três instâncias: a operação efetuada sobre o organismo (estímulo), o comportamento e as consequências. A primeira e a terceira são variáveis. Elas são definidas como as variáveis externas, das quais o comportamento é função, que possibilitam a análise funcional do comportamento (SKINNER, 1998). Dessa forma, o ambiente apresenta estímulos que antecedem o comportamento. Este comportamento provoca consequências que determinarão a sua probabilidade de ocorrência 
no futuro. O aumento das chances de ocorrência do comportamento se dá quando há contingências de reforço, bem como a diminuição ocorre quando há contingências predominantemente punitivas.

Ao aplicar esse modelo de análise à relação entre pais e filhos, como proposto por Bolsoni-Silva (2003, 2008, 2009), pretende-se investigar as situações em que se dão as interações (estímulos antecedentes); as respostas comportamentais, isto é, os comportamentos emitidos pelos pais e pelos filhos e, também, as consequências, ou seja, identificar as práticas parentais que reforçam ou punem comportamentos emitidos pelos filhos e vice-versa.

Tendo em vista que a relação entre pais e filhos é permeada pelo ambiente social, faz-se necessário destacar as influências dos estímulos ambientais sociais. Para Skinner (1998), o comportamento social ocorre quando duas ou mais pessoas se relacionam. Mais especificamente, quando interagem em um ambiente em comum que, no entanto, é afetado também por outras contingências (situações) ambientais e não somente as sociais. Isso quer dizer que outras condições, como, por exemplo, dor, fome, frio, calor, sede, entre outras, podem afetar as interações sociais.

Para a análise das interações sociais, devem ser consideradas as contingências que afetam as mesmas, isto é, os estímulos antecedentes aos comportamentos que podem ser ações emitidas pelos pais, pelos filhos ou mesmo outros estímulos que não são comportamentos.

As consequências dessas ações parentais ou filiais, provavelmente, irão retroagir sobre as ações futuras dos pais e dos filhos. As relações presentes nesse processo são denominadas contingências entrelaçadas (SKINNER, 1998) que, aplicadas à interação entre pais e filhos, implicam em comportamentos emitidos pelos pais e pelos filhos que agem como estímulos para o comportamento do outro, seja um comportamento antecedente seja um consequente. Por exemplo, o caso de uma mãe que fala em tom agressivo com seu filho, isto é, emite um estímulo que antecede o comportamento do filho. Como resposta ao estímulo, recebe deste gritos. A reação de gritar do filho, que foi consequente ao comportamento materno, torna-se um estímulo antecedente ao comportamento da mãe de falar para o filho ir para o quarto, e assim por diante.

Esse entrelaçamento de comportamentos não é fácil de detectar por completo, pois nem sempre eles são discriminados pelos atores das interações sociais (SKINNER, 1998). No estudo mencionado, nem sempre as mães e os filhos conseguem discriminar o que controla os seus comportamentos, já que, além de suas interações, podem ser diversas as condições que afetam os comportamentos de ambos. Exemplos dessas condições que afetam a conduta têmse na situação sócio-econômica, nas regras parentais e/ou culturais que podem influenciar os 
comportamentos parentais e filiais, nas ações passadas dos pais que agem sobre o comportamento atual dos filhos e vice-versa.

Sobre as interações sociais, também é necessário destacar a importância dos reforçadores que, para serem considerados sociais, requerem a presença de outra pessoa. Os reforçadores podem ser vistos quando os pais conversam, elogiam e abraçam os seus filhos, ou mesmo quando a mãe reforça o comportamento de birra do filho. Skinner (1998) afirma que há os reforçadores positivos sociais generalizados, entre os quais estão a atenção, a aprovação, a afeição e a submissão, e os reforçadores negativos, que são a desaprovação, os insultos e o desprezo. Sob efeito dos reforçadores positivos, os filhos mantêm ou aumentam a frequência de conversar, elogiar, agradar, cooperar com os pais; sob a ação de reforçadores negativos, os filhos aumentam a frequência de comportamentos para fugir ou escapar de desaprovações ou humilhações.

No ambiente social, os reforçadores podem variar, pois dependem das condições que afetam o agente reforçador (SKINNER, 1998). Na relação entre pais e filhos, pode-se dizer que tanto os pais quanto os filhos podem agir como agentes reforçadores. Por exemplo: a mãe pode reforçar um comportamento emitido pelo filho ao elogiá-lo; o filho pode aumentar a probabilidade de que a mãe venha a elogiá-lo novamente, por isso tenta agradá-la, ou mesmo o comportamento do jovem pode ser generalizado ou estendido para outras situações semelhantes, nas quais ele pode vir a se comportar tentando obter reforçadores sociais na interação com outras pessoas.

Andery, Micheletto e Sério (2005) afirmam que as condições que afetam o agente reforçador serão determinantes para o ritmo da mudança da contingência. Eles dizem que “[...] é do comportamento promovido pelas contingências que se originam as novas condições de exigência do agente reforçador, o que, por sua vez, conduz à mudança, por parte deste agente, das exigências estabelecidas para reforçamento" (ANDERY; MICHELETTO; SÉRIO, 2005, p. 156).

Transpondo o conhecimento dos autores citados para a relação entre mães e filhos, citase o exemplo da mãe que apresenta uma regra ao filho. Dependendo do comportamento deste, a mãe apresentará diferentes reações: se ele a obedecer, ela poderá reforçar a obediência com atenção social; se ele não a obedecer, ela poderá deixar de reforçar, retirando a atenção. Assim será possível perceber a mudança de contingências influenciadas pelos estímulos antecedentes, no caso em que o filho obedece, ou não. Os estímulos antecedentes, que afetam o comportamento dos agentes reforçadores, no entanto, não são tão fáceis de ser detectados, 
principalmente quando se trata de estímulos não presentes na situação imediata (SKINNER, 1998).

As condições que afetam os agentes reforçadores podem ser as mais variadas. Tudo depende do momento atual do indivíduo quando interage com o outro. Depende também da sua história e das suas experiências anteriores, que são influenciadas pelo ambiente cultural. A cultura determina os padrões de comportamento de uma comunidade, dos quais alguns são reforçados e outros não (SKINNER, 1998). A prática cultural é formada a partir do comportamento social, que é mais ampla por envolver a transmissão de comportamentos operantes de uma geração para outra (ANDERY; MICHELETTO; SÉRIO, 2005). Skinner (1998) afirma ser mais fácil identificar as contingências observadas no ambiente social do que explicar as razões dessas contingências culturais. Nas palavras do autor (p. 452), "Algumas delas (contingências culturais) são arranjadas por razões que não têm conexão com o efeito dos usos e costumes no grupo" (SKINNER, 1998, p. 452).

Segundo Andery, Micheletto e Sério (2005), é difícil identificar e descrever todas as contingências culturais envolvidas nas relações estabelecidas para o reforço dos comportamentos em dada cultura. O comportamento influenciado pela cultura é considerado complexo, pois envolve relações comportamentais entrelaçadas (SKINNER, 1998). Nesse sentido, ao estudar as relações entre mães e filhos, nem sempre é possível identificar as contingências culturais presentes nessas interações, É mais fácil acessar as contingências entrelaçadas presentes no ambiente social, isto é, presentes nas interações entre as mães e seus filhos. Essas interações podem ser observadas e analisadas por meio da contingência de três termos, que permite a análise funcional dessa interação.

Dentro desse contexto, a proposta de Bolsoni-Silva (2003, 2008, 2009) pretende, por meio da identificação dos comportamentos emitidos pelas mães e pelos filhos, realizar a análise funcional das contingências entrelaçadas presentes na relação entre pais e filhos. Para realizar tal procedimento, a autora buscou variáveis organizadoras do comportamento social nas categorias de análise do modelo de habilidades sociais (DEL PRETTE, 1999; DEL PRETTE, 2001), aplicadas às interações estabelecidas entre pais e filhos (BOLSONI-SILVA, 2003).

As habilidades sociais que os pais utilizam com o intuito educativo são denominadas Habilidades Sociais Educativas Parentais (BOLSONI-SILVA, 2003) e equivalem a um conjunto de habilidades sociais que os pais aplicam na prática educativa dos filhos. Essas habilidades referem-se às práticas parentais voltadas ao estímulo e ao desenvolvimento das habilidades sociais no adolescente e permitem a transmissão de padrões, valores e condutas 
que possibilitam a socialização do adolescente e a competência em interações sociais (BOLSONI-SILVA, 2003; BOLSONI-SILVA; MARTURANO, 2006). Na interação entre pais e filhos, as habilidades parentais são essenciais ao desenvolvimento de habilidades sociais e/ou problemas de comportamento dos jovens (BOLSONI-SILVA E MARTURANO, 2007).

Para a categorização das habilidades sociais educativas parentais, Bolsoni-Silva (2003) baseou-se na classificação das habilidades sociais de Del Prette e Del Prette (2001), a partir da qual selecionou as seguintes habilidades: (a) habilidade social de comunicação, a qual envolve fazer e responder perguntas, pedir e dar feedback nas relações sociais, iniciar, manter e encerrar conversação; (b) habilidade social assertiva de enfrentamento, a qual envolve manifestar opinião, concordar e discordar; (c) habilidade de expressão de sentimentos que engloba expressar raiva, expressar sentimentos positivos e demonstrar apoio ao outro.

Após a emissão do comportamento social de pais ou filhos surtirão consequências ou efeitos sobre o ambiente que, ao serem avaliados, podem ser classificados como habilidosos, ou não. Essa avaliação é denominada pelos estudiosos das habilidades sociais de competência social (DEL PRETTE; DEL PRETTE, 2001).

Del Prette e Del Prette (2008) citam a importância de se levar em consideração a funcionalidade do comportamento para poder classificá-lo como habilidoso, ou não. Em outras palavras, faz-se necessário considerar a relação entre as instâncias de respostas observáveis, verificando os antecedentes (estímulos discriminativos) e consequentes (observados ou inferidos) relacionados ao comportamento. É importante, por isso, destacar os diferentes contextos de participação das pessoas. Elas irão contribuir para a aprendizagem ou não de habilidades sociais, em especial as experiências advindas da relação com os pais que podem ou não estimular as habilidades sociais dos filhos (BOLSONI-SILVA, 2003, 2008, 2009).

Estudos (BOLSONI-SILVA, 2003, 2008; DEL PRETTE; DEL PRETTE, 2001; ARÓN; MILICIC, 1994; GOMIDE, 2003) propõem a influência da família sobre o desenvolvimento das habilidades sociais. "O estilo familiar, os padrões de recompensa e punição, o sistema de crenças e os valores são elementos que têm um impacto importante no desenvolvimento das habilidades sociais" (ARÓN; MILICIC, 1994, p. 26).

Para Bolsoni-Silva e Marturano (2002), a área teórico-prática de treinamento das habilidades sociais - THS - é enriquecedora para a compreensão das variáveis funcionais da relação entre pais e filhos e das práticas parentais. Essas autoras citam seis aspectos importantes para a avaliação das práticas parentais: (a) o desempenho interpessoal e as 
autorregras parentais; (b) a compreensão de si e do contexto que pode interferir na relação positiva ou negativa dos filhos; (c) a assertividade como essencial para dialogar com o adolescente; (d) a aprendizagem social como fonte de benefício para toda a família; (e) a importância da leitura do ambiente social parental que pode favorecer a aprendizagem desta habilidade por parte dos filhos; (f) a expressão de sentimentos positivos, de elogios e de afeto como primordial para a formação da autoestima e do autoconceito do filho.

Os aspectos citados são congruentes com os encontrados em diversos outros estudos sobre práticas parentais, citados anteriormente (BAUMRIND, 1966, 1996; MACCOBY; MARTIN, 1983; PATTERSON; REID; DISHION, 1992; STANTIN; KERR, 2000; PETTI $e t$ al., 2001; FLETCHER et al., 2004; BORAWSKI et al., 2003; MCGUE et al., 2005; PLUNKETT et al., 2007; LUYCKX et al., 2007; SOENENS et al., 2005; HA et al., 2009; SHELTON; HAROLD, 2008; GOMIDE, 2003, 2004, 2006; BOLSONI-SILVA, 2003, 2008, 2009; REPPOLD et al., 2002; CIA; PAMPLIN; DEL PRETTE, 2006; TEIXEIRA; OLIVEIRA; WOTTRICH, 2006; AVANCI et al., 2007).

As habilidades sociais educativas parentais que previnem problemas de comportamento são compostas por categorias comportamentais amplas que envolvem a comunicação, a expressão de sentimentos, o enfrentamento e o estabelecimento de limites por parte dos pais (BOLSONI-SILVA, 2003, 2008, 2009). O repertório dos pais pode ser investigado e classificado como habilidoso quando as habilidades sociais educativas parentais citadas ocorrem com frequência e em situações adequadas para tal. Será classificado como não habilidoso quando há ausência ou pouca frequência de habilidades sociais educativas. O repertório dos filhos também pode ser avaliado e classificado como habilidoso, ou não, o que depende de suas ações nas interações familiares.

A comunicação parental envolve comportamentos verbais de pais, mães ou cuidadores que iniciam e mantêm a conversação, fazem perguntas e conversam sobre sexualidade (BOLSONI-SILVA, 2008). Conforme enfatizado por autores da área de habilidades sociais (DEL PRETTE; DEL PRETTE, 2001; CABALLO, 2003), a comunicação é fundamental para o convívio em sociedade. Sendo assim, é de extrema importância que os pais conversem e dialoguem com seus filhos, estimulando neles o repertório inicial para o desenvolvimento posterior de outras habilidades sociais (SILVA, 2000).

Bolsoni-Silva (2003, 2009) aponta para a importância de se detectar a forma de manifestação das interações familiares em relação à comunicação. Em outras palavras, essa autora valoriza a identificação das ocasiões em que os pais conversam com seus filhos, chamando a atenção para os assuntos e a forma com que os filhos respondem às interações. 
Stanttin e Kerr (2000) afirmam que a comunicação entre pais e filhos é o principal instrumento de prevenção de problemas de comportamento na adolescência, de modo que a comunicação está associada ao controle parental não coercitivo. Para os autores, o controle e a vigilância parental são importantes, mas não devem excessivos, de acordo com as pesquisas sobre coerção e suas implicações para os filhos (SIDMAN, 2001; GOMIDE, 2003; BOLSONI-SILVA, 2003), já que atentam para os efeitos colaterais da utilização excessiva da punição sobre o desenvolvimento humano. Em função disso, é essencial investigar os métodos que os pais utilizam para controlar o comportamento do adolescente. Stattin e Kerr (2000) propõem, por isso, que os pais procurem conhecer seus filhos, o que se dá de três maneiras: revelação do filho, solicitação parental e controle parental.

A revelação do adolescente ocorre quando ele fala e conta aos pais espontaneamente sobre si (STATTIN; KERR, 2000). O adolescente deve ser estimulado a fazer isso a partir da audiência não punitiva, da aceitação da opinião do filho e da expressão de afeto à sua família desde cedo (BOLSONI-SILVA, 2003, 2008; GOMIDE, 2003, 2006). Levar os filhos à busca da conversa com seus pais é uma dica importante, visto que essa relação está pautada em contingências reforçadoras positivas (BOLSONI-SILVA; MARTURANO, 2006). Quanto ao comportamento dos pais de somente conversar com seus filhos quando há problemas de comportamento, pode ser uma amostra de que há problemas de comunicação familiar, o que configura a predominância de contingências coercitivas.

As solicitações parentais ocorrem quando os pais fazem perguntas aos filhos e aos seus amigos sobre suas atividades e seu dia a dia. A habilidade social educativa parental é, por isso, definida por Bolsoni-Silva $(2003,2008)$ como a habilidade de comunicação que visa a realização de perguntas sobre a vida do filho.

A partir do controle parental, os pais podem estipular regras sobre as atividades, os locais, os horários e as companhias do adolescente, mostrando-lhe as consequências que resultam de seu comportamento. Essa proposta está em consonância com as habilidades sociais educativas parentais de comunicação e estabelecimento de limites (BOLSONI-SILVA, 2008). A habilidade de comunicação enfatiza a importância dos pais conversarem com os filhos atentamente sobre temas diversos, e a habilidade para estabelecer limites orienta os filhos ao cumprimento de regras.

Fletcher, Steinberg e Williams-Wheeler (2004) afirmam que a revelação espontânea por parte do adolescente é influenciada pelo comportamento parental. Em outras palavras, quando os filhos são estimulados a conversar com seus pais desde cedo, aqueles tendem a se comunicar espontaneamente com estes e, consequentemente, os pais vão conhecer a vida do 
filho, o que aumenta a possibilidade de orientação não coercitiva. Há menos incidência de problemas de comportamento do adolescente quando os pais apresentam grande conhecimento sobre as atividades dele (STANTTIN; KERR, 2000).

Como destacado por Bolsoni-Silva e Marturano (2006), faz-se necessário que os pais tenham momentos de comunicação atenciosa e não punitiva com os filhos. Dessa forma, aumenta-se a possibilidade de diálogo na família e dá-se oportunidade ao filho para contar sobre sua vida, isto é, o adolescente oferece aos pais a oportunidade de orientação e estes recebem maior probabilidade de serem ouvidos. A forma como os filhos reagem nos momentos de comunicação é um indicativo para verificar se os filhos estão agindo de forma habilidosa. Nesse caso, mostrarão disponibilidade e interesse. Por outro lado, quando os adolescentes estão com problemas na comunicação, agem de forma desinteressada, afastam-se dos pais e/ou mudam de assunto (BOLSONI-SILVA, 2003, 2008).

Um estudo brasileiro, desenvolvido por Cia, Pamplin e Del Prette (2006), investigou a correlação da comunicação entre pais e filhos e as habilidades sociais dos filhos. Foi encontrada uma associação positiva entre altos escores de comunicação de pais e filhos e a competência social destes. A pesquisa concluiu que a comunicação entre eles é uma variável estimuladora do desenvolvimento do repertório habilidoso, o que respalda a afirmação de Bolsoni-Silva e Marturano (2002) de que a ação dos pais é um modelo de comportamento para os jovens. Em outras palavras, os pais que se comunicam com seus filhos de forma habilidosa lhes proporcionam o estímulo para que também façam uso dessa habilidade em suas interações sociais.

Referente à comunicação voltada para a sexualidade, Bolsoni-Silva (2003) considera a conversa sobre sexo um comportamento habilidoso quando os pais atentam para as dúvidas e o comportamento dos filhos, bem como quando aqueles respondem a estes com a verdade. A comunicação sobre sexualidade não está alienada aos demais temas. Ela é influenciada, na verdade, pelo estilo familiar de comunicação em geral (DIAS; GOMES, 1999).

O tema em questão, no entanto, é envolvido por mitos, tabus e preconceitos de ordem cultural que acabam dificultando as orientações que os pais precisam dar aos filhos (SILVARES, 2002). Segundo essa autora, a informação sobre esse assunto torna o adolescente mais preparado para tomar decisões em relação ao seu comportamento sexual. Além disso, o adolescente que recebe orientação tende a iniciar as atividades sexuais mais tardiamente (ROMER et al., 1997).

A importância da habilidade social educativa parental de comunicação, eleita pelo estudo de Bolsoni-Silva (2003, 2008, 2009), está em consonância com as propostas citadas 
(STANTTIN; KERR， 2000; GOMIDE， 2003， 2006; FLETCHER; STEINBERG; WILLIAMS-WHEELER, 2004; CIA; PAMPLIN; DEL PRETTE, 2006). A comunicação entre pais e filhos estimula a proximidade da família, aumentando o conhecimento dos pais sobre a vida dos filhos e a habilidade de comunicação dos jovens. Consequentemente, diminui-se a probabilidade de problemas de comportamento do adolescente.

A habilidade social educativa parental de expressão de sentimentos e enfrentamento é, conforme Bolsoni-Silva (2008), uma referência aos comportamentos verbais dos cuidadores para a expressão dos sentimentos. Quando o indivíduo exprime seus sentimentos, ele o faz de modo positivo e negativo e, com o enfrentamento, ele emite opiniões e demonstra o carinho.

A expressividade emocional honesta e contextualizada previne problemas de comportamento, pois, os pais, ao expressarem seus sentimentos, possivelmente estão ensinando a seus filhos os comportamentos esperados para aquele ambiente e talvez para a sociedade em geral (BOLSONI-SILVA; MARTURANO, 2002). Os pais agem como modelo de comportamento aos filhos e, por isso, devem incentivá-los a ser assertivos na expressão dos sentimentos, das opiniões e das críticas.

Autores da área de treinamento em habilidades sociais (DEL PRETTE; DEL PRETTE, 2005) valorizam a honestidade e a assertividade na expressão de sentimentos para que haja congruência entre as ações, os sentimentos e os princípios. Eles destacam que o indivíduo que vive num ambiente punidor da expressão emocional pode aprender a disfarçar, evitar situações emocionais, o que talvez traga dificuldades de interação afetiva. Esses autores também defendem que os pais e/ou responsáveis auxiliem seus filhos a reconhecer e nomear as emoções, a conversar sobre elas, a expressar sentimentos positivos e negativos de forma adequada, a lidar com a emoção positiva e negativa (medo, raiva, vergonha), a tolerar frustrações e a adquirir bom humor para lidar com as emoções.

Para expressar adequadamente os sentimentos, os pais precisam discriminar quais dos comportamentos dos filhos são adequados e inadequados. Esses pais precisam identificar também os próprios sentimentos para não punir ou reforçar o comportamento do adolescente de acordo com as suas emoções (BOLSONI-SILVA, 2008; GOMIDE, 2004, 2006). Os pais devem, em outras palavras, expressar sentimentos contingentes às situações vivenciadas na relação com o adolescente. Eles devem refletir sobre a forma e o momento de expressar sentimentos positivos e negativos. Esses sentimentos devem ser levados em consideração na análise funcional do comportamento dos pais e dos filhos.

Os pais devem ficar atentos à ocorrência de comportamentos habilidosos dos filhos. Nesse sentido, a família deve expressar sentimentos positivos como, por exemplo, elogiar e 
expressar agrado, o que, consequentemente, aumentará a probabilidade da aquisição do repertório habilidoso (BOLSONI-SILVA, 2003, 2009). Gomide (2004) afirma que os pais devem transmitir ao filho que ele é importante, amado, capaz e encontrar as melhores formas para demonstrar o real interesse pela vida do adolescente.

Bolsoni-Silva (2003) e Gomide (2003) destacam para a importância da criação de contingências positivas preventivas para os problemas de comportamento. Sidman (2001), por sua vez, valoriza os reforçadores positivos contingentes a atitudes pró-sociais dos filhos. Este autor, no entanto, alerta os pais para não desenvolverem o amor condicional, isto é, aquele em que o filho sente a necessidade de fazer algo especial para obter o amor dos pais. $\mathrm{O}$ sentimento deixa de ser um reforçador positivo e torna-se negativo. Para que isso não venha a acontecer, é importante que os pais mantenham as contingências positivas de proteção e afeto em qualquer circunstância.

Para que a expressão de sentimentos negativos seja habilidosa, isto é, seja uma oportunidade de aprendizagem para a família, os pais precisam apontar o comportamento inadequado ao adolescente e mostrar as alternativas a este (BOLSONI-SILVA; MARTURANO, 2002). Diante de comportamentos não desejáveis, os pais devem auxiliar o filho a realizar a autocrítica, permitindo que ele perceba as consequências do próprio comportamento para que as evite no futuro e encontre formas de reparar o dano (GOMIDE, 2004). Os pais devem especificar o comportamento inadequado, dizer o que sentiram, avaliando o contexto. Além disso, devem auxiliar o adolescente a encontrar alternativas, sem fazer uso de agressões verbais, ameaças e acusações (BOLSONI-SILVA, 2003). Os pais devem punir os comportamentos inadequados sem jamais produzir dano ao ser, isto é, sem ameaçar a retirada de afeto ou proteção parental (GOMIDE, 2004).

Deve-se levar em consideração que os pais podem apresentar dificuldades para discriminar as contingências em ação, os seus próprios comportamentos e sentimentos. Em função disso, Bolsoni-Silva (2009) aponta que pode faltar autoconhecimento ${ }^{13}$ aos pais, o que pode levá-los a ter pouca habilidade na expressão de sentimentos positivos e negativos. A reação pouco habilidosa dos filhos é mais provável quando os pais também não sabem ao certo quando e como expressar sentimentos positivos e negativos. Em consonância com a proposta, Weber (2007) destaca que é importante os pais primeiramente conhecerem o seu próprio comportamento para depois poderem ensinar e prevenir comportamentos

\footnotetext{
${ }^{13}$ Para a análise do comportamento, o autoconhecimento ocorre quando o indivíduo discrimina suas ações e as variáveis controladoras do seu comportamento (SKINNER, 1998).
} 
inadequados. A autora diz também que dificilmente os pais conseguirão a consistência nas práticas educativas sem o autoconhecimento.

A habilidade social educativa de expressar opiniões envolve comportamentos como manifestar opinião concordante ou discordante em relação ao comportamento do filho de forma sincera, adequada ao contexto e assertiva, respeitando a opinião da outra pessoa, mesmo que seja discordante (BOLSONI-SILVA, 2008). É importante verificar de que forma os pais expressam suas opiniões e como os adolescentes reagem, isto é, se os genitores o fazem mostrando o que pensam e sentem e se os filhos reagem de forma habilidosa ou, ainda, de forma não habilidosa passiva ou não habilidosa ativa.

Quanto às ações mencionadas, a habilidosa fundamenta-se em comportamentos que estimulam as habilidades do adolescente. Essas condutas incentivam o adolescente a expressar sua opinião por meio de audiência compreensiva. A reação não habilidosa passiva, por sua vez, é a punição negativa do comportamento do filho. Essa reação é caracterizada por ações passivas, como, por exemplo, não demonstrar interesse pelo filho e ignorar quando o adolescente expressa o que pensa e sente. Já a reação não habilidosa ativa é a punição positiva do comportamento do filho. Por exemplo, cita-se a crítica de forma agressiva, o grito, o xingamento e a não aceitação de que o filho pense de forma diferente.

O estudo de Alberti e Emmons (2008) aponta alguns comportamentos assertivos de enfrentamento importantes para a competência social. Eles podem ser aplicados a favor das habilidades sociais educativas parentais. São eles: (a) defender os próprios interesses e opiniões respeitando o outro, (b) saber negar pedidos e estabelecer limites de tempo e de energia disponível e (c) reagir a críticas e a censuras de forma autocontrolada.

Os autores anteriormente mencionados destacam as habilidades de exercer os próprios interesses sem desconsiderar os dos outros. Bolsoni-Silva e Marturano (2002) também defendem isso na relação entre pais e filhos. Elas motivam falar aos filhos o que se pensa e se sente de forma contextualizada, ouvir respeitosamente a opinião dos filhos, levar em consideração a fase de desenvolvimento do filho (contexto) e criticar somente o necessário para que a relação não se torne excessivamente punitiva. Os pais que punem excessivamente as opiniões dos filhos podem aumentar a probabilidade da supressão desse comportamento destes e vice-versa.

A demonstração de carinho, habilidade social educativa parental que faz parte da categoria expressão de sentimentos e enfrentamento, consiste na emissão de comportamentos verbais e/ou não verbais de agrado aos filhos. Entre esses comportamentos estão beijar, abraçar, elogiar e ajudar o filho na resolução de problemas (BOLSONI-SILVA, 2009). 
A expressão de afeto vem sendo caracterizada pelas mais diversas pesquisas (GOMIDE, 2003, 2004; OTTA, 1994) como variável preventiva dos problemas de comportamento, já que transmite ao filho a sensação de ser amado e aceito, inibindo problemas como a agressividade, a insegurança, a instabilidade e a vulnerabilidade. Baumrind (1966) já afirmava a importância do calor e do afeto para o bem-estar dos filhos. Maccoby e Martin (1983), por sua vez, destacaram o apoio emocional para haver responsividade parental.

Para que os filhos confiem em seus pais, é necessário que eles se sintam aceitos (GOMIDE, 2004). Os jovens que se sentem amados e benquistos depositarão maior confiança em seus pais e, consequentemente, será mais fácil para estes dar-lhes a devida orientação (STATTIN; KERR, 2000). A demonstração de carinho, por isso, permite relações familiares agradáveis. É por isso que o contato com a pele, o abraço, o beijo e o olhar carinhoso são considerados inibidores do desenvolvimento do comportamento agressivo (GOMIDE, 2003; MONTAGU, 1978; OTTA, 1994). A falta de afeto, como apontam diversos estudos, está associada a problemas de comportamento e caracterizada como negligência emocional (GOMIDE, 2003; WEBER et al., 2002).

Na proposta de Habilidades Sociais Educativas Parentais (BOLSONI-SILVA, 2008), o estabelecimento de limites está relacionado ao comportamento verbal de pais, mães ou cuidadores. Eles devem, portanto, identificar as razões pelas quais se estabelece limites, identificar comportamentos que consideram apropriados aos filhos (socialmente habilidosos), identificar comportamentos que não consideram apropriados aos filhos, cumprir promessas, conversar com o cônjuge para estabelecer uma concordância nas práticas educativas, identificar os próprios "erros" e identificar ocasiões e comportamentos que justificam o estabelecimento de limites.

$\mathrm{O}$ estabelecimento de regras e limites como fundamental para o desenvolvimento saudável do filho é apoiado pela literatura internacional (DISHION; MCMAHON, 1998; PATTERSON; REID; DISHION, 1992) e nacional (BOLSONI-SILVA, 2003， 2008; GOMIDE, 2003, 2006). Para muitos autores, porém, esse assunto é chamado de monitoria parental (DISHION; MCMAHON, 1998; PATTERSON; REID; DISHION, 1992; GOMIDE, 2003).

Todo agente educativo tem a responsabilidade de guiar, corrigir e socializar seu educando a partir de comportamentos apropriados. Essas ações dos adultos são denominadas de orientação e disciplina (BARAKAT; CLARK, 2001). Nesse sentido, os autores propõem estratégias de prevenção dos problemas de comportamento na adolescência. Eles dizem que aos pais cabe definir e estabelecer regras consistentes; estabelecer consequências para o não 
cumprimento das regras que não sejam depreciadoras do filho; encorajar o autocontrole, provendo escolhas significativas para o educando e, ainda, focar os comportamentos desejáveis, ao invés dos que devem ser evitados.

A proposta mencionada vai ao encontro da teoria de Bolsoni-Silva $(2003,2008)$ sobre a importância do reforçamento positivo contingente aos comportamentos pró-sociais e da punição comedida contingente aos comportamentos problemáticos. É necessário, no entanto, manter a consistência na aplicação de consequências para o cumprimento ou descumprimento de regras anteriormente estabelecidas (BOLSONI-SILVA, 2003, 2008, 2009).

Para Bolsoni-Silva, Del Prette e Oishi (2003), o estabelecimento de limites é necessário nas situações em que o filho e/ou outras pessoas correm risco de segurança, quando há danos materiais de terceiros e/ou dos próprios. Nesses casos, os pais precisam ser consistentes em suas ações. Eles precisam, na verdade, saber como e em que situação é necessário dizer não e não ceder às pressões dos filhos. Ao mesmo tempo, aqueles precisam se manter atentos para elogiar comportamentos adequados, prevenindo, assim, os inadequados.

Para que os pais consigam agir de forma consistente, Bolsoni-Silva (2003) destaca para a importância da discriminação parental sobre o que é considerado certo e errado, sobre a razão e a situação em que se deve aplicar limites, bem como sobre o comportamento parental usado para estabelecer limites. Os pais devem também explicar aos filhos porque tal comportamento deve ser evitado, quais as consequências desse mesmo comportamento para si próprio e para as demais pessoas (BOLSONI-SILVA, 2003, 2008).

O estudo de Fletcher, Steinberg e Williams-Wheeller (2004) vai ao encontro da teoria de Bolsoni-Silva $(2003,2008)$ ao mostrar que adolescentes são menos propensos ao uso de substâncias quando seus pais, além de calorosos e envolvidos em suas vidas, proveem-se de níveis adequados de controle sobre as atividades do adolescente. Mais especificamente, os pais que se comunicam com seus filhos, os monitoram, estabelecem regras e as cumprem apresentam maior conhecimento e controle sobre o comportamento deles.

Observa-se uma inter-relação entre as diversas habilidades sociais educativas parentais, que são definidas e descritas separadamente, porém, exercem influência mútua sobre o comportamento do filho. Os pais que se comunicam habilidosamente com seus filhos provavelmente sabem mais sobre ele. Consequentemente, os mentores têm maior liberdade para fazer perguntas sobre a vida do filho, facilitando o estabelecimento de limites que poderá ser menos coercitivo. Dessa forma, pode aumentar a probabilidade de que o jovem aceite as orientações dadas pelos pais. 
O comportamento de cumprir promessas, item que faz parte da categoria estabelecimento de limites (BOLSONI-SILVA, 2008), faz com que os filhos confiem em seus pais. Se fosse ao contrário, eles se sentiriam enganados e promoveriam prejuízo à relação (SILVA, 2000). Ao prometer e não cumprir, além de decepcionar os jovens agindo de uma forma inconsistente, os pais podem estar ensinando os filhos a não confiar neles (BOLSONISILVA, 2000).

Em consonância com Bolsoni-Silva (2008), Gomide (2004) afirma que os pais, quando estabelecem acordos ou regras e não as cumprem, podem dar margem à aprendizagem de comportamentos disruptivos. Os filhos, nesses casos, podem combinar coisas e não cumprir, não se engajar em suas atividades e responsabilidades, inventar mentiras e apresentar reações desafiadoras e opositoras. Há oportunidades também para o surgimento de comportamentos reativos, como os sentimentos de raiva, tristeza e decepção em relação aos pais. Estes agem como modelo de comportamento para os filhos e, quando envolvidos em comportamentos como mentiras e desvios de conduta, podem influenciar seus filhos a ter comportamentos semelhantes (MARINHO, 2001, 2003).

A categoria estabelecimento de limites também envolve o comportamento dos pais na identificação de seus próprios erros na relação com os filhos (BOLSONI-SILVA, 2003, 2008, 2009). Nas relações humanas em geral, admitir falhas, erros e pedir desculpas não é um comportamento fácil de ser praticado, pois provoca diminuição, mesmo que momentânea, da auto- estima. É por isso considerado como uma habilidade social de enfrentamento com a qual se permite diminuir ressentimentos e superar as divergências (DEL PRETTE; DEL PRETTE, 2001).

Para Del Prette e Del Prette (2003, p. 145) “a classe de habilidades de perdão/ reparação envolve: solicitar perdão; reparar a falta cometida e perdoar ou desculpar". Para admitir seus erros, a pessoa deve reconhecê-los e propor-se a repará-los. O perdão não envolve promessas, nem exige a demonstração de submissão, mas, sim, exige assertividade, tolerância, empatia e reconhecimento das próprias limitações.

A habilidade dos pais para pedir desculpas é considerada essencial na aprendizagem desse comportamento do filho e é realizada, principalmente, por modelação (BOLSONISILVA, 2003). Apesar de sua importância, Silva (2000) diagnosticou que os pais têm receio de admitir seus erros diante dos filhos e de ensiná-los a pedir desculpas, de modo que acabam utilizando meios punitivos. Segundo Ross (1979), os pais, na tentativa de deter o comportamento inadequado, retêm reforço positivo ou proporcionam estímulos aversivos. 
Mesmo assim, o comportamento indesejado persiste, promovendo a manutenção do mesmo e tornando o comportamento paradoxal à visão dos pais.

Em coerência à proposta de Bolsoni-Silva (2003, 2008, 2009), estudiosos do comportamento moral (LEWIS, 1993; LA TAILLE, 2002) afirmam que quando uma pessoa avalia o seu comportamento como negativo, pode aliviar tal sentimento no momento em que o repara. Nesse sentido, La Taille (2002) cita duas formas de reparação pró-sociais e complementares: a confissão e a reparação. Em outras palavras, uma pessoa conta para a outra a ação que gerou culpa e pede perdão. Dessa forma, esta pessoa pode aliviar ou retirar a culpa de quem cometeu o suposto mau comportamento.

Toda pessoa que sente culpa em relação a um mau comportamento cometido contra o outro deve alimentar algum sentimento de compaixão em relação a este. Dessa forma, quando uma pessoa julga que não foi suficientemente generosa com a outra, pode sentir culpa. Evidencia-se, assim, a relação entre o sentimento de culpa e o afeto positivo em relação às demais pessoas (LA TAILLE, 2002).

A habilidade social educativa parental de entendimento do casal também é essencial para estabelecer limites consistentes. Os pais podem concordar, ou não, com as convicções que consideram essenciais na formação do filho, mas podem também discordar e conversar sobre o tema na ausência ou na presença do adolescente (SILVA, 2000). O entendimento conjugal previne os problemas de comportamento do adolescente quando os pais apresentam valores e virtudes semelhantes de como educar um filho e quando conversam sobre as diferenças na ausência do filho. Importante lembrar que ambos devem sempre respeitar a opinião e a autoridade do cônjuge perante o filho (BOLSONI-SILVA, 2003, 2008, 2009).

Em concordância com a Bolsoni-Silva (2003, 2008, 2009), outros estudos demonstram que as divergências de opiniões parentais sobre os comportamentos adequados e inadequados em relação à educação do filho podem confundir o adolescente de como ele deve se comportar. Além disso, essas divergências podem influenciá-lo a ter um comportamento chantagista e manipulador com seus pais (GOMIDE, 2003). Segundo Weber, Salvador e Brandenburg (2006), as divergências entre o casal podem, portanto, tornar as regras inconsistentes.

Para Ha et al. (2009), a baixa qualidade do entendimento do casal influencia o surgimento de problemas de comportamento internalizantes no filho. É o caso da depressão, da solidão e da baixa autoestima do jovem. Já a qualidade positiva da relação do casal está associada ao menor uso do controle psicológico parental, ao maior controle do comportamento do filho e ao maior suporte ao filho. Em outras palavras, quando os pais 
concordam quanto aos comportamentos que consideram adequados aos filhos, é mais fácil obter a coerência na educação do adolescente. A mensagem transmitida a ele é mais clara e consistente; logo, os pais não precisam utilizar de coerção para controlar o comportamento do filho.

Outro estudo aponta para as relações conflituosas entre o casal associados aos problemas de comportamento dos filhos (SHELTON; HAROLD, 2008). Os conflitos são sentidos por estes como uma rejeição, já que a hostilidade presente nas brigas e nos desentendimentos é transmitida ao jovem. Os autores dizem também que os conflitos entre o casal podem estar associados à depressão materna e paterna, considerada fator de risco para problemas de comportamento internalizantes e externalizantes no adolescente.

A proposta de Bolsoni-Silva (2008) busca a avaliação da funcionalidade dos comportamentos emitidos pelos pais e filhos. Nesse sentido, pretende-se analisar as situações antecedentes e/ou consequentes às respostas dos pais/cuidadores em relação ao comportamento dos filhos. A análise parte do relato verbal de pais/cuidadores diante de comportamentos relacionados à comunicação, expressão de sentimentos/enfrentamento e estabelecimento de limites desses pais/cuidadores.

Em relação à qualificação das habilidades sociais educativas em geral, são considerados habilidosos os pais com as seguintes qualidades: que se comunicam de forma assertiva e atenciosa; que fazem perguntas e ouvem seus filhos atentamente em ocasiões oportunas; que expressam sentimentos positivos exaltando a importância do adolescente; expressam sentimentos negativos de forma assertiva e convenientes a situações ou comportamentos inadequados do adolescente; que expressam opiniões em situações adequadas, respeitando as opiniões alheias e as discordâncias; que fazem carinho; que conseguem estabelecer limites coerentes a situações e à idade do filho sem utilizar ameaças e chantagens e os pais que conseguem dialogar de forma assertiva e agir de forma consistente (BOLSONI-SILVA, 2008).

Os pais que com grande frequência utilizam práticas como a ameaça de punição física e psicológica, as chantagens emocionais e as agressões físicas podem ser classificados como não habilidosos ativos. Já aqueles que agem de forma mais passiva e negligente às necessidades do adolescente, ou seja, são pouco comunicativos, pouco expressam sentimentos positivos, expressam sentimentos negativos agressivamente, não estabelecem limites e não conversam com o filho, podem ser considerados não habilidosos passivos (BOLSONISILVA, 2008). 
A partir dessa análise, o comportamento dos filhos também pode ser investigado e classificado em habilidoso ou não habilidoso. Habilidoso é aquele filho que se dispõe e coopera com a comunicação e resolução de problemas; aquele que expressa suas preferências, emite críticas construtivas, expressa carinho e empatia. Não habilidoso é o filho que enfrenta dificuldades de interação social, como a falta de assertividade, a agressividade, a pouca emissão de carinho e de disponibilidade; que tem atitudes problemáticas de comportamento, que podem ser classificadas em internalizantes e externalizantes.

A proposta desenvolvida por Bolsoni-Silva (2000, 2003, 2008, 2009) é, com base nas informações apresentadas, inovadora, já que busca detectar as contingências entrelaçadas presentes nas relações entre pais filhos. É inovadora também porque avalia os comportamentos dos pais e dos filhos, classificando-os como habilidosos ou não habilidosos.

$\mathrm{O}$ assunto é novidade porque as pesquisas até então estavam mais voltadas à detecção e à descrição de práticas e estilos parentais influenciadores do comportamento do filho. A pesquisa de Bolsoni-Silva (2000) veio para destacar a bidirecionalidade das relações, a detecção de seus entrelaçamentos e as consequências para pais e filhos, possibilitando um estudo minucioso dos comportamentos parentais e filiais. 


\subsection{HIPÓTESES E PERGUNTAS DA PESQUISA}

Com base nas informações expostas no referencial teórico, o presente estudo apresenta a hipótese de que nas interações entre mães e filhos do grupo de risco haverá menor incidência de habilidades sociais educativas e maior ocorrência de práticas negativas por parte das mães. E provavelmente seus filhos apresentarão maior frequência de problemas de comportamento e menor, de habilidades sociais nas interações com suas mães. Por outro lado, a hipótese é contrária para as mães de não risco, pois se supõe que elas apresentarão mais habilidades sociais educativas, e seus filhos, menos problemas de comportamento e mais habilidades sociais em suas interações.

O estudo pretende, por isso, responder às seguintes questões: (a) quais são as semelhanças e as diferenças entre as habilidades sociais educativas maternas dos grupos de risco e não-risco? (b) quais são as semelhanças e as diferenças apresentadas pelos grupos no que se refere às situações de contexto familiar? (c) quais são as semelhanças e as diferenças apresentadas pelos grupos em relação ao uso de práticas negativas? (d) há relações funcionais entre as HSE-P maternas e as habilidades sociais dos filhos em ambos os grupos? (e) há relações funcionais entre as práticas negativas e os problemas de comportamento dos filhos em ambos os grupos? (f) pode haver relação entre as habilidades sociais maternas, as práticas negativas e os diagnósticos a respeito do comportamento dos filhos? 


\section{OBJETIVO GERAL}

A partir do estilo materno de risco e não risco para problemas de comportamento em adolescentes, obtido pelo Inventário de Estilo Parental - IEP -, a presente pesquisa busca descrever o perfil de interações sociais estabelecidas entre mães e filhos adolescentes, utilizando como instrumento a análise funcional do comportamento.

\subsection{OBJETIVOS ESPECÍFICOS}

Identificar o estilo e as práticas educativas maternas a partir dos relatos de filhos.

Descrever, correlacionar e comparar as habilidades sociais educativas de mães com estilo de risco e não risco para problemas de comportamento de adolescentes.

Descrever, correlacionar e comparar as práticas negativas de mães com estilo de risco e não risco para problemas de comportamento de adolescentes.

Descrever, correlacionar e comparar as variáveis contextuais das interações de mães com estilo de risco e não risco para problemas de comportamento de adolescentes.

Descrever, correlacionar e comparar as habilidades sociais e os problemas de comportamento de adolescentes dos grupos de risco e não risco.

Investigar a relação entre as habilidades sociais educativas maternas e as habilidades sociais de adolescentes dos grupos de risco e não risco.

Investigar a relação entre as habilidades sociais educativas maternas e os problemas de comportamento de adolescentes dos grupos de risco e não risco.

Verificar a relação entre o estilo materno, as práticas educativas maternas e as habilidades sociais educativas das mães dos grupos de risco e não risco para problemas de comportamento de adolescentes.

Investigar e comparar as classificações diagnósticas dos adolescentes dos grupos de risco e não risco.

Verificar a relação entre as habilidades sociais e os problemas de comportamento com as classificações diagnósticas dos adolescentes dos grupos de risco e não risco. 


\section{MÉTODO}

\subsection{PARTICIPANTES}

Participaram deste estudo 24 mães e seus filhos adolescentes de ambos os sexos, com idades entre 12 e 16 anos, de $7^{\mathrm{a}}$. e $8^{\mathrm{a}}$. séries de um colégio estadual de uma capital da região sul do país. Dentre as mães, 14 foram classificadas como apresentando práticas de risco para problemas de comportamento em adolescentes e 10 de não risco, segundo o Inventário de Estilo Parental Materno - IEP (GOMIDE, 2006). A amostra de adolescentes foi composta por 10 meninos e 14 meninas no total, dos quais seis meninos e oito meninas fizeram parte do grupo de risco e quatro meninos e seis meninas do grupo de não risco para problemas de comportamento.

\subsubsection{DADOS DEMOGRÁFICOS DOS PARTICIPANTES}

Foram coletados os dados demográficos das famílias, através do Roteiro de Entrevista de Habilidades Sociais Educativas Parentais- RE-HSE-P (BOLSONI-SILVA, 2007) aplicados nas mães. Este instrumento investigou: (a) a idade das mães; (b) a idade dos adolescentes; (c) a renda familiar mensal; (d) o estado civil das mães; (e) a escolaridade das mães; (f) a profissão ou ocupação das mães; (g) o fato da mãe trabalhar fora de casa; (h) a jornada de trabalho das mães; (i) o vínculo empregatício das mães; (j) se os filhos moravam com seus pais, seus padrastos, seus pais adotivos ou se os pais eram ausentes na vida de seus filhos.

A análise dos dados demográficos foi realizada através do teste estatístico Crosstabs. Os resultados obtidos pelo teste indicaram a não existência de diferenças estatísticas de todos os dados demográficos avaliados na comparação entre os grupos de risco e não risco para problemas de comportamento em adolescentes. O que permite dizer que os grupos de risco e de não risco são equivalentes em relação às variáveis demográficas e que, portanto, no caso deste estudo as diferenças encontradas nas comparações entre os grupos não podem ser atribuídas a elas. Os dados demográficos são apresentados a seguir:

A idade das mães variou de 30 a 58 anos como pode ser visualizado na Tabela 1: 
Tabela 1- Idades das mães no grupo de risco e de não risco para problemas de comportamento em adolescentes.

\begin{tabular}{lllll}
\hline Idade das mães & Idade & Grupo de risco & Grupo de não risco & Total \\
\cline { 2 - 5 } & 58 & 1 & 0 & 1 \\
& 50 & 1 & 1 & 2 \\
& 46 & 0 & 1 & 1 \\
& 42 & 0 & 1 & 1 \\
& 40 & 1 & 3 & 4 \\
& 39 & 1 & 1 & 2 \\
& 38 & 1 & 0 & 1 \\
& 37 & 0 & 2 & 2 \\
& 36 & 3 & 0 & 3 \\
& 34 & 1 & 0 & 1 \\
Total & 33 & 2 & 0 & 2 \\
& 32 & 1 & 0 & 1 \\
& 31 & 1 & 1 & 2 \\
& 30 & 1 & 0 & 1 \\
& & 14 & 10 & 24 \\
\hline
\end{tabular}

Entre a faixa etária de 30 a 35 anos participaram sete mães, dos 36 aos 40 anos participaram 12 mães, dos 41 aos 45 anos havia uma mãe, dos 46 aos 50 anos participaram três mães e dos 51 anos em diante, houve uma participante. A faixa etária de 30 a 35 anos abrangeu seis participantes do grupo de risco e uma do grupo de não risco para problemas de comportamento no adolescente. A faixa etária de 36 a 40 anos foi composta por seis participantes do grupo de risco e seis do grupo de não risco. A faixa etária de 41 a 45 anos teve uma participante do grupo de não risco. Dos 46 aos 50 anos houve duas participantes do grupo de não risco e uma do grupo de risco. Dos 51 anos em diante participou uma mãe de 58 anos de idade pertencente ao grupo de risco.

A idade dos adolescentes participantes variou dos 12 aos 16 anos de idade, como apresentado na tabela a seguir:

Tabela 2 - Idades dos adolescentes no grupo de risco e de não risco para problemas de comportamento em adolescentes.

\begin{tabular}{lllll}
\hline Idade dos adolescentes & Idade & Grupo de risco & Grupo de não risco & Total \\
\cline { 2 - 5 } & 16 & 3 & 0 & 3 \\
& 15 & 1 & 2 & 3 \\
& 14 & 5 & 5 & 10 \\
& 13 & 5 & 2 & 7 \\
Total & 12 & 0 & 1 & 1 \\
\hline
\end{tabular}

A amostra contou com um participante de 12 anos, sete de13 anos de idade, dez de 14 anos, três de 15 anos e três de 16 anos. Aos doze anos de idade havia um participante do grupo de não risco para problemas de comportamento, aos treze anos de idade havia cinco de risco e dois de não risco, aos quatorze anos de idade havia cinco participantes de risco e cinco de não risco, aos quinze anos de idade havia um de risco e dois de não risco e aos dezesseis anos de idade havia três participantes de risco. 
A renda mensal das participantes variou de 600 reais a 4500 reais, na época da coleta de dados (2008) o valor do salário mínimo era de $\mathrm{R} \$ 415,00$. Portanto a renda mensal das participantes variou, aproximadamente, de um salário mínimo e meio a 11 salários mínimos, como pode ser visualizado, mais detalhadamente, na Tabela 3:

Tabela 3 - Renda familiar mensal, em salários mínimos e valor em reais, no grupo de risco e de não risco para problemas de comportamento em adolescentes.

\begin{tabular}{|c|c|c|c|c|}
\hline \multirow{5}{*}{$\begin{array}{l}\text { Renda } \\
\text { familiar }\end{array}$} & Faixa de renda & Grupo de risco & Grupo de não risco & Total \\
\hline & $\begin{array}{l}\text { Acima de } 7,4 \text { salários mínimos } \\
\text { (acima de } 3100 \text { reais) }\end{array}$ & 2 & 2 & 4 \\
\hline & $\begin{array}{l}5 \text { a } 7,2 \text { salários mínimos }(2100 \text { a } \\
3000 \text { reais })\end{array}$ & 4 & 5 & 9 \\
\hline & $\begin{array}{l}2,6 \text { a } 4,8 \text { salários mínimos (1100 a } \\
2000 \text { reais) }\end{array}$ & 6 & 2 & 8 \\
\hline & $\begin{array}{l}1,4 \text { a } 2,4 \text { salários mínimos }(600 \text { a } \\
1000 \text { reais })\end{array}$ & 2 & 1 & 3 \\
\hline Total & & 14 & 10 & 24 \\
\hline
\end{tabular}

Três famílias apresentaram renda de 1,4 a 2,4 salários mínimos mensais, oito de 2,6 a 4,8 salários mínimos mensais, nove de 5 a 7,2 salários mínimos mensais e quatro renda acima de 7,4 salários mínimos mensais. Da faixa de renda de 1,4 a 2,4 salários mínimos mensais houve duas participantes do grupo de risco e uma de não risco. Da faixa de renda de 2,6 a 4,8 salários mínimos mensais participaram seis mães do grupo de risco e duas de não risco. Da faixa de renda de 5 a 7,2 salários mínimos mensais, quatro eram do grupo de risco e cinco do grupo de não risco. Acima de 7,4 salários mínimos mensais, havia duas participantes do grupo de risco e duas do grupo de não risco.

Em relação ao estado civil as mães foram classificadas em solteiras, casadas, casadas pela segunda vez e envolvidas em relacionamento conjugal sem legalização. A Tabela 4 apresenta a distribuição das mães de acordo com o estado civil:

Tabela 4 - Estado civil das mães no grupo de risco e de não risco para problemas de comportamento em adolescentes.

\begin{tabular}{llll}
\hline Estado civil & Grupo de risco & Grupo de não risco & Total \\
\hline Solteira & 1 & 2 & 3 \\
Casada & 9 & 8 & 17 \\
Casada pela segunda vez & 2 & 0 & 2 \\
Relacionamento conjugal sem legalização & 2 & 0 & 2 \\
Total & 14 & 10 & 24 \\
\hline
\end{tabular}

Sobre o estado civil, três mães eram solteiras, 17 casadas pela primeira vez, duas casadas pela segunda vez, e duas envolvidas em relacionamento conjugal sem legalização. $\mathrm{O}$ grupo de risco foi composto por uma participante solteira, nove casadas pela primeira vez, duas casadas pela segunda vez, duas envolvidas em relacionamento conjugal sem legalização. Das mães do grupo de não risco, duas eram solteiras e oito casadas pela primeira vez. 
A escolaridade das mães foi classificada em ensino fundamental incompleto (FI), fundamental completo (FC), ensino médio incompleto (MI), médio completo (MC), ensino superior incompleto (SI) e superior completo (SC), como apresentado na Tabela 5:

Tabela 5 - Escolaridade das mães no grupo de risco e de não risco para problemas de comportamento em adolescentes.

\begin{tabular}{|c|c|c|c|c|}
\hline \multirow{7}{*}{$\begin{array}{l}\text { Escolaridade das } \\
\text { mães }\end{array}$} & Ensino & Grupo de risco & Grupo de não risco & Total \\
\hline & FI & 4 & 1 & 5 \\
\hline & $\mathrm{FC}$ & 0 & 0 & 0 \\
\hline & MI & 0 & 2 & 2 \\
\hline & $\mathrm{MC}$ & 7 & 4 & 11 \\
\hline & SI & 3 & 1 & 4 \\
\hline & $\mathrm{SC}$ & 0 & 2 & 2 \\
\hline Total & & 14 & 10 & 24 \\
\hline
\end{tabular}

Quanto à escolaridade a maior parte das mães participantes completou o ensino médio (11), duas apresentaram ensino superior completo, quatro ensino superior incompleto, duas ensino médio incompleto e cinco fundamental incompleto. Das quais quatro mães com ensino fundamental incompleto faziam parte do grupo de risco e uma do grupo de não risco. As duas participantes com ensino médio incompleto fizeram parte do grupo de não risco. Sete participantes com ensino médio completo pertenciam ao grupo de risco e quatro ao de não risco. Três mães de ensino superior incompleto faziam parte da amostra de risco e uma mãe ao grupo de não risco. As duas mães que apresentaram a escolaridade de ensino superior completo estavam no grupo de não risco.

As mães apresentaram diversas profissões e ocupações listadas na Tabela 6:

Tabela 6 - Ocupações ou profissões das mães do grupo de risco e de não risco para problemas de comportamento.

\begin{tabular}{llll}
\hline Ocupação/ Profissão & Grupo de risco & Grupo de não risco & Total \\
\hline Estudante & 1 & 0 & 1 \\
Dona de casa & 4 & 1 & 5 \\
Passadeira em lavanderia & 1 & 0 & 1 \\
Autônoma & 1 & 1 & 2 \\
Serviços administrativos & 2 & 2 & 4 \\
Comércio, vendedora & 1 & 1 & 2 \\
Professora & 0 & 1 & 1 \\
Empregada doméstica & 2 & 1 & 3 \\
Enfermeira formada & 0 & 1 & 1 \\
Técnica em enfermagem & 1 & 0 & 1 \\
Aposentada & 0 & 1 & 1 \\
Manicure & 1 & 1 & 2 \\
Total & 14 & 10 & 24 \\
\hline
\end{tabular}

Das profissões e ocupações relatadas pelas mães, havia uma estudante de pedagogia, cinco donas de casa, uma passadeira em lavanderia, duas mães autônomas que tinham negócio próprio, quatro mães trabalhavam com serviço administrativo, duas vendedoras, uma mãe era professora de ensino fundamental, três mães trabalhavam como empregadas domésticas, uma 
atuava como enfermeira e outra como técnica em enfermagem, duas manicures e uma mãe aposentada.

O grupo de risco foi composto por quatro donas de casa, uma passadeira em lavanderia, uma autônoma, duas que atuavam em serviços administrativos, uma vendedora, duas empregadas domésticas, uma técnica em enfermagem e uma manicure. O grupo de não risco foi composto por uma dona de casa, uma autônoma, duas que atuavam em serviços administrativos, uma vendedora, uma professora, uma empregada doméstica, uma enfermeira, uma aposentada e uma manicure.

Foi investigado se as mães trabalhavam fora de casa ou não, como apresentado pela Tabela 7:

Tabela 7 - Características em relação ao serviço, externo ou do lar, das mães do grupo de risco e de não risco para problemas de comportamento em adolescentes.

\begin{tabular}{llll}
\hline & Grupo de risco & Grupo de não risco & Total \\
\hline Não trabalha fora & 5 & 1 & 6 \\
Trabalha fora & 9 & 8 & 17 \\
Aposentada & 0 & 1 & 1 \\
Total & 14 & 10 & 24 \\
\hline
\end{tabular}

Das mães participantes 17 trabalhavam fora, seis não trabalhavam fora e uma estava aposentada. No grupo de risco havia nove mães que trabalhavam fora e cinco que não trabalhavam fora. No grupo de não risco oito mães trabalhavam fora, uma não trabalhava fora e uma estava aposentada.

O horário ou jornada de trabalho das mães também foi investigado, como mostra a Tabela 8:

Tabela 8 - Horário ou jornada de serviço materno do grupo de risco e de não risco para problemas de comportamento em adolescentes.

\begin{tabular}{llll}
\hline Horário de trabalho das mães & Grupo de risco & Grupo de não risco & Total \\
\hline Não Trabalha fora & 5 & 1 & 6 \\
Dia todo & 7 & 5 & 12 \\
Meio período & 1 & 1 & 2 \\
Variado & 1 & 2 & 3 \\
Aposentada & 0 & 1 & 1 \\
Total & 14 & 10 & 24 \\
\hline
\end{tabular}

Das mães que trabalhavam fora, doze trabalhavam o dia todo, duas meio período e três trabalhavam em horários variados. Do grupo de risco, sete trabalhavam o dia todo, uma trabalhava meio período e uma trabalhava em horários variados. Do grupo de não risco, cinco trabalhavam o dia todo, uma trabalhava meio período e duas mães trabalhavam em horários variados.

Foi investigado também o vínculo empregatício das mães que trabalhavam fora, algumas tinham vínculo empregatício formal, outras não, como exposto na Tabela 9: 
Tabela 9 - Vínculo empregatício das mães do grupo de risco e de não risco para problemas de comportamento em adolescentes.

\begin{tabular}{llll}
\hline Empregada com registro em carteira de trabalho & Grupo de risco & Grupo de não risco & Total \\
\hline Não & 4 & 6 & 10 \\
Sim & 5 & 3 & 8 \\
Não trabalha fora & 5 & 1 & 6 \\
Total & 14 & 10 & 24 \\
\hline
\end{tabular}

Das mães que trabalhavam fora, somente oito mães eram empregadas com registro em carteira de trabalho e dez não eram empregadas formalmente, eram prestadoras de serviços. Dado o qual chamou a atenção foi que a maioria das mães trabalhava fora, mas não tinha vínculo empregatício formal.

Dentre os participantes adolescentes, alguns moravam com os pais biológicos, outros com seus padrastos, outros não tinham convívio com seus pais, os quais foram classificados como pais ausentes, e um adolescente tinha pai adotivo, como pode ser visualizado na Tabela 10:

Tabela 10 - Características paternas do grupo de risco e de não risco para problemas de comportamento em adolescentes.

\begin{tabular}{llll}
\hline Paternidade & Grupo de risco & Grupo de não risco & Total \\
\hline Pai & 10 & 7 & 17 \\
Padrasto & 3 & 0 & 3 \\
Pai ausente & 1 & 2 & 3 \\
Pai adotivo & 0 & 1 & 1 \\
Total & 14 & 10 & 24 \\
\hline
\end{tabular}

A maior parte dos adolescentes (17) morava com seus pais biológicos, três com padrastos, três cujos pais eram ausentes e um participante vivia com seu pai adotivo. Dentre o grupo de risco, 10 adolescentes moravam com pais biológicos, três com padrastos e um participante tinha pai ausente. No grupo de não risco, sete adolescentes moravam com seus pais biológicos, dois tinham pais ausentes e um participante tinha pai adotivo.

\subsubsection{CRITÉRIOS PARA A SELEÇÃO DOS PARTICIPANTES}

A aplicação do Inventário de Estilo Parental Materno foi responsável pela seleção da amostra de risco e não risco para problemas de comportamento do adolescente deste trabalho, isto é, diferenciou as mães que apresentaram práticas de risco das mães que apresentaram práticas de não risco para problemas de comportamento do adolescente.

Para comparação entre os grupos dos resultados obtidos pela aplicação do IEP, foram calculadas as médias da frequência de cada prática educativa materna e as médias da 
frequência do índice de estilo materno. Para verificar as diferenças estatísticas entre os grupos foi aplicado o teste Mann-Whitney, como pode ser visto na Tabela a seguir:

Tabela 11 - Médias das frequências das práticas maternas e do índice de estilo materno avaliados pelo IEP e aplicação do teste Mann-Whitney para comparação entre os grupos de risco e não risco para problemas de comportamento do adolescente.

\begin{tabular}{llll}
\hline IEP & Grupo risco & Grupo não risco & Valor \\
\hline & Médias (desvio padrão) & Médias (desvio padrão) & $\mathrm{P}$ \\
Monitoria positiva materna & $6,93(1,73)$ & $11,4(0,70)$ & 0,000 \\
Comportamento moral materno & $6,29(3,00)$ & $11(1,25)$ & 0,000 \\
Punição inconsistente materna & $5,71(2,20)$ & $1,5(1,43)$ & 0,000 \\
Negligência materna & $5,29(2,81)$ & $0,30(0,48)$ & 0,000 \\
Disciplina relaxada materna & $4,93(2,76)$ & $1,20(1,23)$ & 0,000 \\
Monitoria negativa materna & $8,00(2,39)$ & $4,20(1,23)$ & 0,001 \\
Abuso físico materno & $4,64(, 27)$ & $0,40(0,52)$ & 0,000 \\
Índice de estilo materno (IEP) & $-15,29(6,47)$ & $14,80(2,53)$ & 0,000 \\
\hline
\end{tabular}

A partir da Tabela 11, nota-se a existência de diferenças estatísticas significativas ( $\leq$ 0,05) para todas as práticas maternas avaliadas pelo IEP na comparação entre os grupos de risco e não risco, inclusive para o índice de estilo materno. Esses dados apontam que os grupos apresentam diferenças significativas em relação à frequência de práticas positivas e negativas, bem como diferença do índice de estilo materno, variável que promoveu a classificação dos grupos em risco e não risco para problemas de comportamento do adolescente.

Em relação ao índice de estilo materno, as mães do grupo de risco apresentam maior incidência de estilos negativos (média iep risco $=-15,29$ / média iep não risco $=14,8$ e $p$ $=0,00$ ), sendo que quanto mais negativo, maior a incidência de práticas de risco para problemas de comportamento do filho. No que diz respeito às práticas educativas, de forma geral, observa-se que as mães do grupo de risco apresentam maior frequência de todas as práticas negativas e menor de todas as positivas, bem como no grupo de mães de não risco há maior incidência de práticas positivas e menor de práticas negativas.

Quanto às práticas positivas, a monitoria positiva apresenta maiores índices de frequência no grupo de não risco (média risco $=6,9$ / média não risco $=11,4$ ), com diferença estatística significativa $(\mathrm{p}=0,00)$, em relação ao grupo de risco. O comportamento moral também é mais frequente no grupo de não risco (média risco $=6,2$ / média não risco $=11$ ) que no grupo de risco, com diferença estatística relevante $(\mathrm{p}=0,00)$.

Todas as práticas negativas são mais frequentes no grupo de risco para problemas de comportamento do adolescente, com diferenças estatísticas significantes entre os grupos. A prática de punição inconsistente apresenta maior frequência no grupo de risco (média $=5,71$ ) 
que no de não risco (média $=1,5)$, com diferença estatística significante $(\mathrm{p}=0,00)$. A prática de negligência apresenta média de 5,29 no grupo de risco e 0,3 no de não risco, havendo diferença estatística significativa $(\mathrm{p}=0,00)$. A disciplina relaxada apresenta frequência média no grupo de risco de 4,93 e 1,2 no grupo de não risco, apresentando diferença estatística significativa $(\mathrm{p}=0,00)$. A monitoria negativa obteve média 8 no grupo de risco e 4,2 no grupo de não risco, com diferença estatística relevante $(\mathrm{p}=0,01)$. $\mathrm{O}$ abuso físico apresenta média de 4,64 no grupo de risco e média 0,4 no grupo de não risco, sendo uma diferença estatística significante entre os grupos $(\mathrm{p}=0,00)$.

A busca de correlações entre as variáveis do IEP foi realizada através da aplicação do teste Spearman, o qual possibilita verificar se há diferenças entre a frequência de práticas maternas dentro de cada grupo. A Tabela 12 apresenta os resultados dessa análise para todas as práticas educativas maternas, bem como para o índice de estilo materno, no grupo de risco para problemas de comportamento do adolescente.

Tabela 12 - Correlação Spearman das práticas educativas maternas e do índice de estilo materno, obtidos através do IEP, no grupo de risco para problemas de comportamento do adolescente.

\begin{tabular}{|c|c|c|c|c|c|c|c|c|}
\hline $\begin{array}{l}\text { Correlação } \\
\text { Spearman }\end{array}$ & $\begin{array}{l}\text { Monitoria } \\
\text { positiva }\end{array}$ & $\begin{array}{l}\text { Comportamento } \\
\text { moral }\end{array}$ & $\begin{array}{l}\text { Punição } \\
\text { inconsistente }\end{array}$ & Negligência & $\begin{array}{l}\text { Disciplina } \\
\text { relaxada }\end{array}$ & $\begin{array}{l}\text { Monitoria } \\
\text { negativa }\end{array}$ & $\begin{array}{l}\text { Abuso } \\
\text { físico }\end{array}$ & $\begin{array}{l}\text { IEP } \\
\text { Materno }\end{array}$ \\
\hline $\begin{array}{l}\text { Monitoria } \\
\text { positiva }\end{array}$ & - & - & - & - & - & - & - & - \\
\hline $\begin{array}{l}\text { Comportamento } \\
\text { moral }\end{array}$ & - & - & - & - & - & - & - & - \\
\hline $\begin{array}{l}\text { Punição } \\
\text { inconsistente }\end{array}$ & - & - & - & - & - & - & - &,$- 598^{*}$ \\
\hline Negligência & - & - & - & - & - & - & - &,$- 593 *$ \\
\hline $\begin{array}{l}\text { Disciplina } \\
\text { relaxada }\end{array}$ & - & - & - & - & - & - & - & - \\
\hline $\begin{array}{l}\text { Monitoria } \\
\text { negativa }\end{array}$ & - & - & - & - & - & - & - & - \\
\hline Abuso físico & - & - & - & - & - & - & - & - \\
\hline $\begin{array}{l}\text { Índice de estilo } \\
\text { materno (IEP) }\end{array}$ & - & - &,$- 598^{*}$ &,$- 593^{*}$ & - & - & - & - \\
\hline
\end{tabular}

Legenda: Os números com asterisco representam os valores que apontam para correlações, os demais itens não apresentaram correlações.

Os resultados da Correlação Spearman obtidos com o grupo de risco para problemas de comportamento do adolescente, apresentados na Tabela 12, mostram que o Índice de estilo materno (IEP) obteve correlações negativas com a punição inconsistente e com a negligência. Isto é, quanto maior a frequência de práticas negativas como a punição inconsistente e a negligência, menores os índices de estilo materno. $\mathrm{O}$ que faz sentido visto que quanto maior a 
incidência de práticas negativas, menor é o índice de estilo materno, e quanto mais negativo é o IEP, maior o risco para problemas de comportamento do filho.

As correlações entre as práticas do grupo de não risco para problemas de comportamento do adolescente foram obtidas através da aplicação do mesmo teste. A Tabela 13 apresenta os resultados da correlação Spearman para todas as práticas educativas maternas, bem como para o índice de estilo materno, no grupo de não risco para problemas de comportamento do adolescente.

Tabela 13 - Correlação Spearman das práticas educativas maternas e do índice de estilo materno, obtidos através do IEP, no grupo de não risco para problemas de comportamento do adolescente.

\begin{tabular}{|c|c|c|c|c|c|c|c|c|}
\hline $\begin{array}{l}\text { Correlação } \\
\text { Spearman }\end{array}$ & $\begin{array}{l}\text { Monitoria } \\
\text { positiva }\end{array}$ & $\begin{array}{l}\text { Comportamento } \\
\text { moral }\end{array}$ & $\begin{array}{l}\text { Punição } \\
\text { inconsistente }\end{array}$ & Negligência & $\begin{array}{l}\text { Disciplina } \\
\text { relaxada }\end{array}$ & $\begin{array}{l}\text { Monitoria } \\
\text { negativa }\end{array}$ & $\begin{array}{l}\text { Abuso } \\
\text { físico }\end{array}$ & $\begin{array}{l}\text { IEP } \\
\text { Materno }\end{array}$ \\
\hline $\begin{array}{l}\text { Monitoria } \\
\text { positiva }\end{array}$ & - & - & - & - & - & - & - & - \\
\hline $\begin{array}{l}\text { Comportamento } \\
\text { moral }\end{array}$ & - & - & - & - &, $638 *$ & ,639* & - & - \\
\hline $\begin{array}{l}\text { Punição } \\
\text { inconsistente }\end{array}$ & - & - & - & - & - & - & - &,$- 762^{*}$ \\
\hline Negligência & - & - & - & - & - & - & - & - \\
\hline $\begin{array}{l}\text { Disciplina } \\
\text { relaxada }\end{array}$ & - & ,638* & - & - & - &, $820 * *$ & - &,$- 656^{*}$ \\
\hline Monitoria neg. & - & ,639* & - & - &, $820 * *$ & 1,000 & - &,$- 635^{*}$ \\
\hline Abuso físico & - & - & - & - & - & - & - & - \\
\hline $\begin{array}{l}\text { Índice de estilo } \\
\text { materno (IEP) }\end{array}$ & - & - &,$- 762 *$ & - &,$- 656^{*}$ &,$- 635^{*}$ & - & - \\
\hline
\end{tabular}

Legenda: Os números com asterisco representam os valores que apontam para correlações, os demais itens não apresentaram correlações.

As correlações obtidas com o grupo de não risco, apresentadas na Tabela 13, apontam para o índice de estilo materno (IEP) correlacionado negativamente às práticas negativas de punição inconsistente, disciplina relaxada e monitoria negativa. O que permite dizer que quanto maior o índice de estilo materno, menor a frequência das práticas negativas de punição inconsistente, disciplina relaxada e monitoria negativa. Sobre as práticas maternas são apontadas correlações negativas entre a prática positiva de comportamento moral e as práticas negativas disciplina relaxada e monitoria negativa. $O$ que significa que as mães que transmitem valores através do comportamento moral, com pouca frequência utilizam da disciplina relaxada e da monitoria negativa. Correlação negativa foi encontrada entre as práticas negativas disciplina relaxada e monitoria negativa. $\mathrm{O}$ que permite afirmar que no grupo de não risco, as mães que utilizam da disciplina relaxada, isto é, colocam regras e não 
as cumprem, não fazem uso da monitoria estressante caracterizada pelo excesso de fiscalizações.

De forma geral, os dados obtidos pelo IEP mostraram que houve maior frequência de práticas positivas no grupo de não risco e pouca freqüência de práticas negativas no mesmo grupo. Entre as mães do grupo de risco houve maior freqüência de práticas negativas e pouca frequência de práticas positivas. As correlações mostraram que as ações das mães do grupo de não risco são mais consistentes que as das mães do grupo de risco.

As análises acima descritas evidenciam as características que diferenciam os grupos e que permitem classificá-los como de risco e de não risco, o que norteará todas as análises subseqüentes para responder as perguntas do presente estudo.

\subsection{LOCAL}

A coleta de dados com os adolescentes foi realizada em sala de aula coletiva. E as mães foram entrevistadas individualmente na sala de apoio pedagógico da escola estadual.

\subsection{INSTRUMENTOS}

Foram utilizados três instrumentos para coleta de dados, dentre eles:

a) Inventário de Estilo Parental Materno- IEP (GOMIDE, 2006): formato do inventário para filhos que respondem sobre os comportamentos maternos. Este instrumento foi utilizado com o intuito de selecionar os grupos de risco e de não risco para problemas de comportamento dos filhos.

O IEP é composto por questões sobre as práticas educativas positivas (comportamento moral e monitoria positiva) e sobre as práticas negativas (monitoria negativa, disciplina relaxada, negligência, abuso físico e punição inconsistente). Contém 42 questões, sendo seis questões acerca de cada prática educativa materna. As respostas são dispostas em escala likert: sempre (2), às vezes (1) ou nunca (0). O índice de estilo parental é obtido pela soma das práticas positivas subtraída da soma das negativas, calculado na folha de resposta do inventário. O índice de estilo parental negativo é indicador da prevalência de práticas 
negativas as quais se sobrepõem as positivas. $\mathrm{O}$ índice de estilo parental materno menor ou igual a -2 é classificado como estilo materno de risco para problemas de comportamento do filho. O índice de estilo parental materno maior ou igual a 11 é considerado como estilo materno de não risco para problemas de comportamento do filho, isto é, indica forte presença de práticas positivas, as quais são promotoras do comportamento pró-social dos filhos e preventivas de problemas de comportamento dos mesmos. Os índices de estilo materno medianos, maiores que -2 e menores que 11 , são considerados regulares. O IEP permite o diagnóstico de famílias de risco ou não risco social.

b) Roteiro de Entrevista de Habilidades Sociais Educativas Parentais- RE-HSE-P (BOLSONI-SILVA, 2009): entrevista na qual as mães respondem questões acerca dos seus antecedentes comportamentais, dos seus comportamentos, das consequiências de suas atitudes para com o seu filho e das reações comportamentais dos filhos. Este instrumento foi selecionado, principalmente, por permitir a análise funcional das interações entre mães e filhos.

O RE-HSE-P contém ao total 70 itens, dentre eles o registro de dados demográficos da família e possui alpha de 0,846. Com a ressalva de que este instrumento foi validado para mães e pais de pré-escolares, sendo este o primeiro trabalho a utilizá-lo com mães de adolescentes. O RE-HSE-P avalia a ocorrência de habilidades sociais aplicáveis às práticas educativas, em escalas likert com três alternativas: nunca ou quase nunca (0), algumas vezes (1), freqüentemente (2), organizadas em frequência positiva (soma de duas perguntas concordância parental e conversa sobre sexualidade) e frequência negativa (comportamento que os pais desaprovam, expressa sentimento negativo, dificuldade em cumprir promessas). Perguntas abertas acerca de 12 Habilidades Sociais Educativas Parentais (HSE-P) focalizam aspectos específicos das interações pais-filhos, abrangendo não somente as HSE-P, mas também práticas educativas negativas, problemas de comportamento infanto-juvenis e habilidades sociais de crianças e adolescentes. $\mathrm{O}$ instrumento possui dois fatores: características positivas da interação (total positivo, habilidades sociais educativas, variáveis de contexto, frequência positiva e habilidades sociais dos filhos) e características negativas da interação (total negativo, práticas negativas, frequência negativa e problemas de comportamento dos filhos). A descrição detalhada das categorias de análise do RE-HSE-P está em anexo (Anexo A).

c) Checklist do comportamento de crianças e adolescentes, de 6 a 18 anos, para paisChild Behavior Checklist- CBCL (ACHENBACH, 1991): inventário respondido pelas mães em relação aos comportamentos emitidos pelos filhos. Este foi utilizado para obtenção do 
diagnóstico sobre o comportamento do adolescente e, para verificar se os dados sobre o comportamento do adolescente, identificados pelo RE-HSE-P, são confirmados pelo CBCL.

A versão traduzida do CBCL foi cedida pela Profa. Dra. Edwiges Silvares, da USP de São Paulo, a qual possui os direitos autorais da ASEBA (Achenbach System of Empirically Based Assessment) no Brasil; o software $A D M$ de avaliação também foi importado com a autorização da mesma. O CBCL permite agrupar os resultados em dois âmbitos: competência social e problemas de comportamento. A competência social é agrupada em 3 escalas: atividade, sociabilidade e escolaridade, sendo que a soma dos escores brutos das três escalas fornece o escore final de competência social. Os problemas de comportamento, por sua vez, são agrupados nas escalas internalização e externalização. A escala de internalização se subdivide em retraimento, queixas somáticas, ansiedade e depressão; já a escala de externalização em comportamento delinquente e comportamento agressivo. Há ainda as subescalas de problemas com o contato social, problemas com o pensamento e problemas de atenção. A soma da pontuação bruta obtida por todas as sub-escalas leva ao escore de distúrbio total comportamental. $\mathrm{O}$ instrumento permite a classificação do repertório comportamental infanto-juvenil em clínico, borderline e não clínico. A amostra clínica é composta por participantes que apresentam distúrbios de comportamento já instaurados (escore bruto acima do percentil 98); a borderline por adolescentes com problemas de comportamento, os quais são de risco para o desenvolvimento de distúrbios (escore acima do percentil 92 e menor que 98); e o grupo não clínico apresenta repertório comportamental considerado competente no meio social, podendo haver alguns problemas de comportamento, mas a sua frequência e a composição de comportamentos não são considerados de risco para distúrbios delinquentes e agressivos (externalizantes) ou depressivos e ansiosos (internalizantes).

\subsection{PROCEDIMENTOS PARA A COLETA DE DADOS}

a) Foi realizado o contato com a Secretaria de Estado da Educação do Paraná (SEED) através da carta de apresentação do projeto desta pesquisa. Esta continha a explicação dos procedimentos deste trabalho e solicitava a autorização da SEED para a aplicação dos instrumentos descritos em estudantes, de 11 a 18 anos de idade, e em suas respectivas mães. (Apêndice A). Também foi entregue para a SEED a carta de aprovação deste projeto emitida 
pelo Comitê de Ética em Pesquisa da Faculdade de Ciências da UNESP de Bauru (Apêndice B). A Secretaria de Estado da Educação do Paraná (SEED) autorizou a realização desta pesquisa (Apêndice C).

b) Realizou-se o contato com os diretores de diversas escolas da cidade para solicitar a permissão para a realização desta pesquisa (Apêndice D). Após o aceite de um diretor de uma escola estadual, partiu-se para os procedimentos de coleta de dados.

c) O primeiro passo foi enviar uma carta para as mães, pais ou responsáveis solicitando a autorização para que os filhos respondessem ao Inventário de Estilo Parental Materno (GOMIDE, 2006) em sala de aula (Apêndice E). Os alunos autorizados foram convidados a responder ao Inventário, cada participante recebeu uma carta de informação sobre a pesquisa (Apêndice F), perfazendo um total de 294 adolescentes. Dos 294 adolescentes autorizados, 276 responderam ao Inventário de Estilo Parental Materno individualmente, em sala de aula coletiva. Este procedimento possibilitou iniciar a pesquisa a partir dos relatos dos adolescentes sobre as práticas educativas maternas e, principalmente, detectar os estilos maternos de risco e não risco para problemas de comportamento do adolescente.

d) Os 276 Inventários de Estilos Parentais Maternos foram tabulados. Os resultados mostraram que 144 mães apresentaram índices negativos, os quais indicam a prevalência das práticas maternas de risco para problemas de comportamento dos filhos, e 24 mães apresentaram índices positivos, indicativos da prevalência das práticas maternas de não risco para problemas de comportamento dos adolescentes ${ }^{14}$. Também foram detectados os resultados medianos, nos quais 43 mães apresentaram estilos medianos acima da média e 65 estilos medianos abaixo da média. O que significa que essas mães apresentaram práticas educativas que não são consideradas de extremo risco (estilo mediano abaixo da média) e nem de excelência para o não risco (estilo mediano acima da média). As mães de estilos medianos não participaram deste trabalho, foram selecionadas para este estudo, as mães com estilo de risco e as com estilo de não risco para problemas de comportamento do adolescente, pelo fato de representarem os extremos necessários para esta pesquisa.

e) Das 144 mães com estilo de risco e 24 com estilo de não risco para problemas de comportamento no adolescente, foram selecionadas 48 mães, sendo 24 de risco e 24 de não

\footnotetext{
${ }^{14}$ Tais resultados indicam a necessidade de intervenções voltadas para a relação entre mães e filhos. Tendo em vista que 144 adolescentes perceberam suas mães como utilizando práticas de risco, o que representa $52 \%$ da população que respondeu ao inventário de estilo materno. E somente 24 adolescentes perceberam suas mães como utilizando as práticas positivas, isto é, somente $9 \%$ teve uma percepção mais positiva sobre as práticas maternas.
} 
risco. Portanto, foram selecionadas as mães que foram relatadas pelos filhos como apresentando estilo materno de risco e as mães que foram relatadas pelos filhos como tendo estilo de não risco (estilo parental ótimo), os dois extremos. A pesquisadora entrou em contato com as mães via telefone para convidá-las a participar da segunda fase da pesquisa, das quais 14 mães classificadas como tendo estilo de risco e 10 mães de não risco compareceram às entrevistas.

f) Na segunda fase desta pesquisa, as 24 mães, que aceitaram participar do estudo, receberam esclarecimentos sobre os objetivos da pesquisa e assinaram um Termo de Consentimento Livre e Esclarecido (Apêndice G). Em seguida, responderam ao Roteiro de Entrevista de Habilidades Sociais Educativas Parentais- RE-HSE-P e ao Child Behavior Checklist de 6 a 18 anos- CBCL.

\subsection{PROCEDIMENTOS PARA O TRATAMENTO E PARA A ANÁLISE DE DADOS}

Os dados referentes à aplicação do Inventário de Estilo Parental Materno- IEP-, instrumento que selecionou a amostra de risco e não risco, foram tabulados manualmente para a folha de resposta conforme instrução (GOMIDE, 2006). Transferidos para o programa estatístico SPSS10 for windows e para o programa excel. Para comparação entre os grupos dos resultados obtidos pela aplicação do IEP, foi necessário: (a) calcular a média da frequência de cada prática educativa; (b) calcular a média da frequência dos índices de estilo materno; (c) aplicar o teste Mann-Whitney para verificar se haviam diferenças entre as médias da frequência das práticas e dos estilos maternos utilizados pelos grupos de risco e não risco, o que permitiu a comparação entre os grupos. Foram considerados os resultados a partir de $5 \%$ de significância. A busca de correlações entre as variáveis do IEP para cada grupo (risco e não risco) foi realizada através da aplicação do teste Spearman do programa SPSS 10 for Windows, o qual viabilizou a identificação da existência ou não de diferenças internas dentro de cada grupo.

Os dados obtidos por meio da aplicação do Roteiro de Entrevista de Habilidades Sociais Educativas Parentais- RE-HSE-P- foram computados em planilha do programa Excel e organizados conforme as instruções de Bolsoni-Silva (2009). Foram calculadas as médias das áreas avaliadas pelo RE-HSE-P através do programa Excel. A comparação entre os grupos referente às habilidades sociais educativas maternas, às práticas negativas maternas, às 
variáveis de contexto, às habilidades sociais e aos problemas de comportamento do adolescente, foi realizada através do teste $U$ de Mann-Whitney, do programa de estatística SPSS for Windows. Foram considerados os resultados a partir de 5\% de significância. Adicionalmente, foram conduzidas análises qualitativas referentes à comunicação, à expressão de sentimentos e enfrentamento e ao estabelecimento de limites, o que facilitou a identificação de contingências em operação. Para análise dos dados demográficos foi utilizado o teste Cross-tabs, para verificar se haviam diferenças demográficas entre os grupos. A busca de correlações entre as variáveis do RE-HSE-P para cada grupo (risco e não risco) foi realizada através da aplicação do teste Spearman do programa SPSS 10 for Windows.

Para análise dos dados referentes ao Child Behavior Checklist -CBCL(ACHENBACH, 1991), estes foram computados para o programa ADM. Este programa permite a classificação geral de cada participante como clínico, borderline ou não clínico. As médias obtidas foram transferidas para o programa excel e para o programa estatístico SPSS for Windows, no qual foi aplicado o teste Mann-Whitney para comparação dos resultados do grupo de risco e não risco para problemas de comportamento no adolescente. 


\section{RESULTADOS}

A seção de resultados apresenta-se na seguinte seqüência: (a) Comparação dos resultados do grupo de risco e não de risco para as categorias do Roteiro de Entrevista de Habilidades Sociais Educativas Parentais (RE-HSE-P); (b) Apresentação da análise qualitativa do RE-HSE-P; (c) Correlação das Habilidades Sociais Educativas Maternas de cada grupo; (d) Apresentação das classificações diagnósticas obtidas através do Child Behavior Check List (CBCL) e comparação destes resultados entre os grupos.

A comparação das médias obtidas nas categorias do RE-HSE-P, entre os grupos de mães de risco e de não risco para problemas de comportamento do adolescente, foi realizada através do teste Mann Whitney, como apresentado na Tabela 14:

Tabela 14 - Médias das categorias do RE-HSE-P e aplicação do teste Mann-Whitney para comparação entre o grupo de risco e de não risco para problemas de comportamento do adolescente.

\begin{tabular}{|c|c|c|c|}
\hline \multirow[t]{2}{*}{ RE-HSE-P } & Grupo risco & Grupo não risco & Valor \\
\hline & Médias (desvio padrão) & Médias (desvio padrão) & $\mathrm{p}$ \\
\hline $\begin{array}{l}\text { Habilidades sociais educativas maternas } \\
\text { (HSEP) }\end{array}$ & $4,21(2,45)$ & $13,40(4,62)$ & 0,000 \\
\hline Práticas negativas maternas & $9,35(6,08)$ & $1,3(1,05)$ & 0,000 \\
\hline Contexto & $8,42(3,89)$ & $16,7(5,88)$ & 0,001 \\
\hline Frequência práticas positivas maternas & $1,42(0,85)$ & $2,1(1,28)$ & - \\
\hline Frequências práticas negativas maternas & $3,5(1,5)$ & $2,2(0,91)$ & 0,015 \\
\hline Total práticas positivas maternas & $18,5(7,11)$ & $46,7(14,03)$ & 0,000 \\
\hline Total práticas negativas maternas & $22,14(10,84)$ & $4,5(2,41)$ & 0,000 \\
\hline Habilidades sociais dos filhos & $4,42(2,62)$ & $14,5(5,31)$ & 0,000 \\
\hline Problemas de comportamento dos filhos & $9,29(5,01)$ & $1,00(1,33)$ & 0,000 \\
\hline
\end{tabular}

$\mathrm{Na}$ comparação entre as mães dos grupos de risco e não risco para problemas de comportamento do adolescente, conforme mostra a Tabela 14, há diferenças estatísticas significativas na maior parte das áreas analisadas pelo RE-HSE-P. Com exceção da variável "frequência de práticas positivas maternas" que não apresenta diferença estatística significativa entre os grupos $(\mathrm{p}=0,08)$, apesar do grupo de não risco apresentar maior frequência destas práticas. Com relação às habilidades sociais educativas (HSEP), as mães do grupo de não risco apresentam maior frequência de HSEP que as do grupo de risco, com diferença estatística relevante $(\mathrm{p}=0,00)$. As práticas negativas são mais frequentes nas mães do grupo de risco (média $=9,35$ ) que nas mães do grupo de não risco (média $=1,3$ ), com diferença estatística significativa $(\mathrm{p}=0,00)$. As situações de contexto, que representam as ocasiões de interação entre mães e filhos, são mais frequentes entre o grupo de não risco (média $=16,7)$ que no grupo de risco (média $=8,42)$, com diferença estatística significativa $(\mathrm{p}=$ 
0,00). A frequência de práticas negativas maternas apresenta diferença estatística significativa na comparação entre os grupos $(\mathrm{p}=0,015)$, o grupo de mães de risco apresenta maior frequência de práticas negativas que o grupo de mães de não risco. Quanto ao total de práticas positivas e negativas, há diferenças estatísticas significantes entre os grupos. Dentre as práticas positivas, as mães do grupo de risco apresentam menor frequência (média = 18,5) em relação às mães do grupo de não risco (média $=46,7$ ), dentre as práticas negativas as mães do grupo de risco apresentam índices mais altos $($ média $=22,14)$ que as mães do grupo de não risco (média $=4,5)$.

No que diz respeito ao comportamento dos filhos, as habilidades sociais (HS) dos adolescentes do grupo de risco (média $=14,5$ ) são menos frequentes que dos filhos do grupo de não risco (média $=4,42)$, com diferença estatística significativa $(\mathrm{p}=0,00)$. E os problemas de comportamento dos filhos do grupo de risco são mais frequentes (média $=9,29$ ) que no grupo de não risco (média $=1,00)$, com diferença estatística significativa $(\mathrm{p}=0,00)$.

As análises qualitativas dos resultados obtidos através do RE-HSE-P estão organizadas na seguinte sequiência: a) Classificação em habilidoso ou não habilidososo, no que se refere às habilidades sociais educativas maternas, ao total de práticas educativas positivas maternas e às habilidades sociais dos filhos; b) Análise comparativa entre os grupos de risco e de não risco sobre as categorias do RE-HSE-P, as quais envolvem comunicação, expressão de sentimentos e enfrentamento, estabelecimento de limites e a habilidade de entendimento conjugal; c) As análises gerais obtidas pelo RE-HSE-P.

As médias das habilidades sociais educativas maternas (HSE-P) possibilitam a classificação do comportamento materno em habilidoso ou não habilidoso, bem como a classificação dos comportamentos dos filhos. Para tanto a Tabela 15 disponibiliza os dados referentes às médias obtidas pelos grupos.

Tabela 15 - Comparação das médias de habilidades sociais educativas maternas, do total de práticas positivas maternas e das habilidades sociais dos filhos entre os grupos de risco e não risco para problemas de comportamento do adolescente.

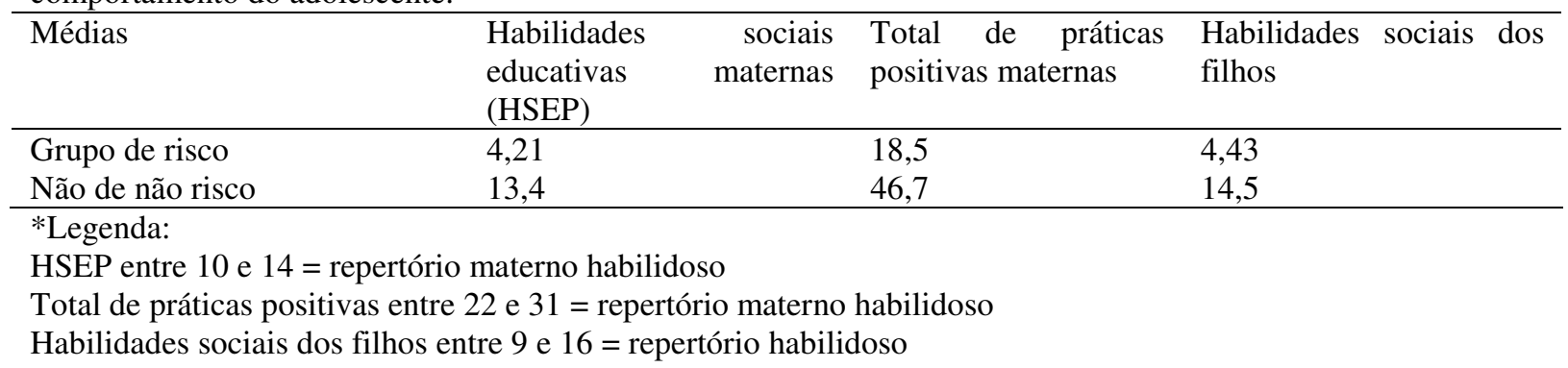

Observando a Tabela 15, nota-se que as mães do grupo de não risco apresentam médias mais altas de habilidades sociais educativas (HSE-P) sendo classificadas como 
habilidosas socialmente. Já as médias referentes às HSE-P das mães do grupo de risco são mais baixas, sendo consideradas não habilidosas. Quanto ao total de práticas positivas maternas estas são mais frequentes no grupo de não risco, sendo a média deste grupo caracterizada como habilidosa e a média do grupo de risco como não habilidosa. Quanto às habilidades sociais dos filhos, os adolescentes do grupo de não risco apresentam média mais alta $(14,5)$, podendo classificá-los como habilidosos. Já os adolescentes do grupo de risco apresentam médias mais baixas, características do repertório não habilidoso.

Com relação à frequência dos participantes classificados como habilidosos ou não habilidosos, nos quesitos explanados anteriormente, a Tabela 16 expõe os resultados obtidos:

Tabela 16 - Frequência da classificação referente às habilidades sociais educativas maternas, ao total de práticas positivas e às habilidades sociais dos filhos dos grupos de risco e não risco para problemas de comportamento do adolescente.

\begin{tabular}{llll}
\hline Participantes & $\begin{array}{l}\text { Habilidades sociais educativas } \\
\text { maternas (HSE-P) }\end{array}$ & Total de práticas positivas & $\begin{array}{l}\text { Habilidades } \\
\text { filhos (HS) }\end{array}$ \\
\hline Grupo de risco & 0 habilidosos & 8 positivas & 1 habilidoso \\
& 14 não habilidosos & 6 abaixo do limiar & 13 não habilidosos \\
Grupo de não risco & 8 habilidosos & 9 positivas & 9 habilidosos \\
& 2 não habilidosos & 1 abaixo do limiar & 1 não habilidoso \\
\hline
\end{tabular}

A partir da Tabela 16 se pode observar que nenhuma mãe da amostra de risco é classificada como habilidosa no quesito habilidades sociais educativas maternas (HSE-P), isto é, as mães da amostra de risco não se mostram habilidosas socialmente nos aspectos avaliados pelo RE-HSE-P. Entre a população de não risco, oito mães são classificadas como habilidosas, isto é, apresentam habilidades sociais educativas, e duas como não habilidosas, não apresentam habilidades sociais educativas suficientes.

Com relação ao total de práticas positivas, oito mães da amostra de risco apresentam práticas positivas e seis mães apresentam práticas positivas abaixo do limiar para serem classificadas como habilidosas. No grupo de não risco, nove mães apresentam práticas positivas e uma apresenta práticas positivas abaixo do limiar.

No que diz respeito às habilidades sociais dos filhos, somente um adolescente da amostra de risco é classificado como habilidoso. Já no grupo de não risco, nove participantes são caracterizados como habilidosos e somente um não habilidoso.

As análises qualitativas das categorias relativas ao RE-HSE-P envolvem comunicação, expressão de sentimentos e enfrentamento, estabelecimento de limites e a habilidade de entendimento conjugal referentes às práticas educativas. São apresentadas as comparações entre o grupo de risco e não risco para problemas de comportamento, através da explanação de cada uma das categorias específicas, as quais contem subcategorias. 
A categoria comunicação envolve as subcategorias conversa com o filho, faz perguntas gerais e faz perguntas de sexualidade. Quanto à subcategoria conversa com o filho, os dados estão apresentados, de forma geral, na Figura 1:

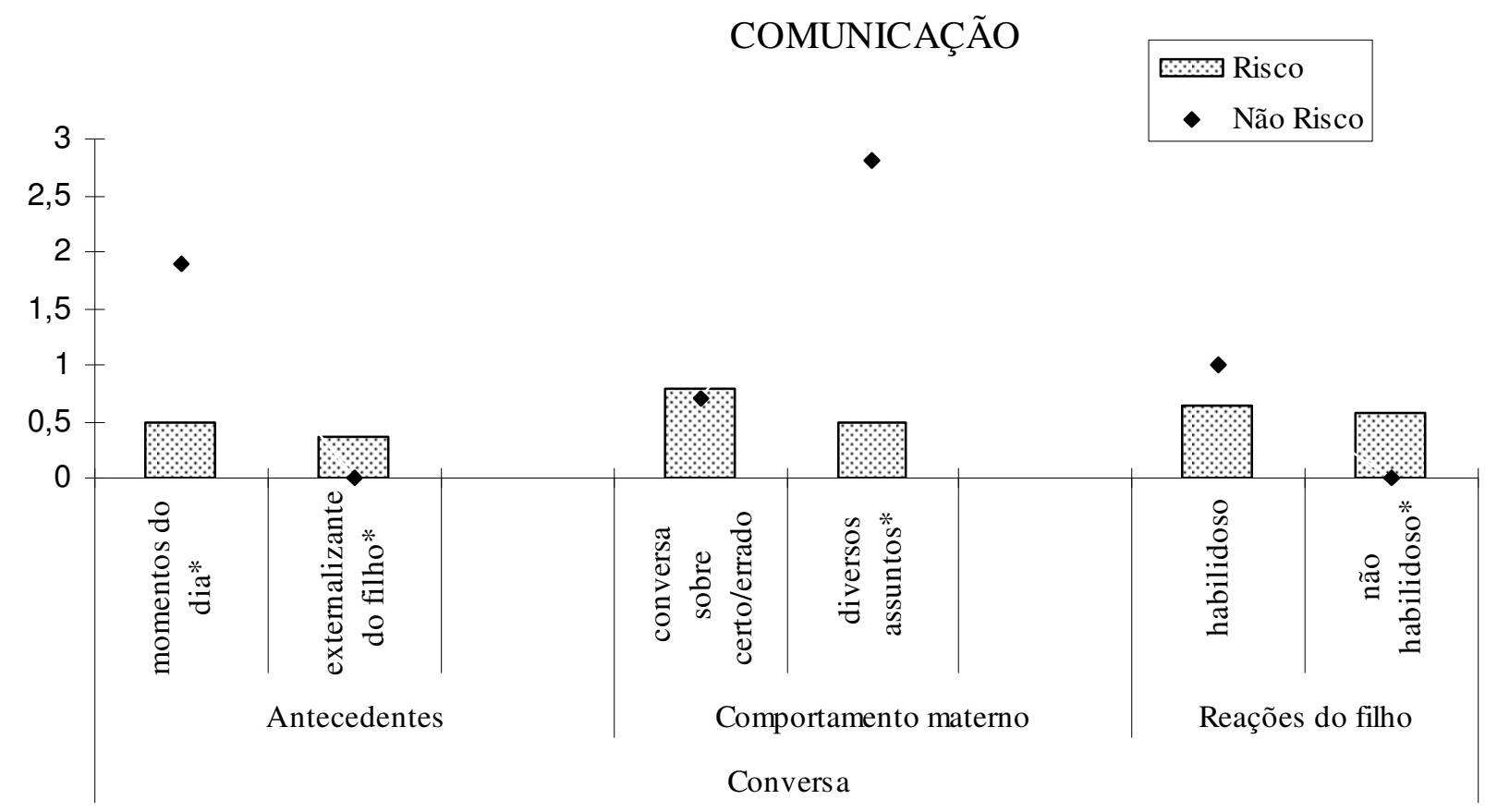

Figura 1 - Comparação entre amostra de risco e não risco sobre a frequência da subcategoria conversa com o filho, das Habilidades Sociais Educativas Parentais (HSE-P) de comunicação. As diferenças estatísticas significantes estão representadas pelos asteriscos *.

A comparação da subcategoria conversa, entre amostra de risco e não risco (Figura 1), mostra que os momentos para conversas entre mães de não risco e seus filhos ocorrem com maior frequência em diferentes momentos do dia e sobre diferentes assuntos, situações em que foram detectadas diferenças estatísticas significativas (média risco $=0,5$ / média não risco $=1,9$ e p=0,013 e média risco $=0,5$ / média não risco $=2,8$ e p $=0,00$, respectivamente).

As mães da amostra de não risco apresentam mais habilidades sociais de comunicação, pelo fato de conversarem mais em diversos momentos e com maior variedade de temas. Já as mães do grupo de risco conversam com maior frequência diante de problemas externalizantes dos filhos, o que não ocorre com as mães do grupo de não risco (média risco $=0,36$ / média não risco $=0$ e $\mathrm{p}=0,03$ ). Dado o qual pode sinalizar o fato das mães do grupo de risco provavelmente darem atenção demasiada aos problemas de comportamento, o que pode reforçar e promover a manutenção dos mesmos, visto que os adolescentes desta amostra apresentam maior frequência de problemas de comportamento (média risco $=0,57$ /média não risco $=0$ e $p=0,02)$. 
Não houve diferenças estatísticas significantes na comparação das habilidades sociais dos adolescentes de ambos os grupos em situações de conversa (média risco $=0,64$ / média não risco $=1$ e $\mathrm{p}=0,17$ ) e nem sobre o comportamento materno de conversar sobre o que é certo e o que é errado (média risco $=0,79$ /média não risco $=0,7 / \mathrm{p}=0,82$ ).

Para aprofundar a análise dos comportamentos encontrados na subcategoria conversa, a Tabela 17 apresenta a descrição e a frequência dos comportamentos emitidos pelas mães e filhos, de ambos os grupos, no que se refere a conversar.

Tabela 17 - Descrição e frequência dos comportamentos apresentados pelas mães e filhos de ambos os grupos na subcategoria conversa com o filho.

\begin{tabular}{|c|c|c|c|c|c|}
\hline Conversa & & Risco & Frequência & Não risco & Frequência \\
\hline \multirow{4}{*}{$\begin{array}{l}\text { Antecedente do } \\
\text { comportamento } \\
\text { materno }\end{array}$} & \multirow{4}{*}{$\begin{array}{l}\text { Problema } \\
\text { (Conversa } \\
\text { diante de } \\
\text { problemas } \\
\text { externalizantes } \\
\text { dos filhos) }\end{array}$} & Filho mente & 2 & & \\
\hline & & Filho fica muito & 1 & & \\
\hline & & Não faz a lição & 1 & & \\
\hline & & $\begin{array}{l}\text { Fica trancado no } \\
\text { quarto }\end{array}$ & 1 & & \\
\hline \multirow{8}{*}{$\begin{array}{l}\text { Contingências } \\
\text { em que ocorrem } \\
\text { os } \\
\text { comportamentos } \\
\text { maternos }\end{array}$} & \multirow{8}{*}{$\begin{array}{l}\text { Contexto } \\
\text { (Momentos do dia) }\end{array}$} & Sempre & 1 & Sempre & 6 \\
\hline & & À noite & 1 & $\begin{array}{l}\text { Frente a } \\
\text { perguntas }\end{array}$ & 2 \\
\hline & & Ao assistirem TV & 2 & Ao & 2 \\
\hline & & & & $\begin{array}{l}\text { assistirem } \\
\text { TV }\end{array}$ & \\
\hline & & Refeição & 1 & Refeição & 2 \\
\hline & & Pedidos & 1 & $\begin{array}{l}\text { No } \\
\text { caminho } \\
\text { para escola }\end{array}$ & 2 \\
\hline & & & & & 2 \\
\hline & & & & $\begin{array}{l}\text { Em } \\
\text { passeios }\end{array}$ & 1 \\
\hline \multirow{15}{*}{$\begin{array}{l}\text { Comportamento } \\
\text { materno } \\
\text { (Sobre o que as } \\
\text { mães } \\
\text { conversam) }\end{array}$} & \multirow[t]{5}{*}{$\begin{array}{l}\text { Contexto } \\
\text { (Concepções de } \\
\text { certo e errado) }\end{array}$} & $\begin{array}{l}\text { Concepções de certo e } \\
\text { errado }\end{array}$ & 6 & $\begin{array}{l}\text { Concepções } \\
\text { de certo e } \\
\text { errado }\end{array}$ & 7 \\
\hline & & Mentiras & 1 & & \\
\hline & & $\begin{array}{l}\text { Sobre o } \\
\text { comportamento do } \\
\text { filho }\end{array}$ & 1 & & \\
\hline & & Drogas & 1 & & \\
\hline & & Escola & 1 & & \\
\hline & \multirow[t]{10}{*}{ Contexto (temas) } & Horários para acordar & 1 & Amizades & 6 \\
\hline & & Drogas & 1 & Escola & 10 \\
\hline & & Finanças & 1 & $\begin{array}{l}\text { Futuro } \\
\text { profissional }\end{array}$ & 7 \\
\hline & & Namoro & 2 & $\mathrm{TV}$ & 2 \\
\hline & & Serviços/ profissão & 1 & $\begin{array}{l}\text { Brincadeira } \\
\mathrm{S}\end{array}$ & 1 \\
\hline & & Sair à noite & 1 & Namoro & 1 \\
\hline & & & & $\begin{array}{l}\text { Novas } \\
\text { tecnologias }\end{array}$ & 1 \\
\hline & & & & Orkut & 1 \\
\hline & & & & Respeito & 1 \\
\hline & & & & Religião & 1 \\
\hline
\end{tabular}




\begin{tabular}{|c|c|c|c|c|c|}
\hline & & & & $\begin{array}{l}\text { Sexualidad } \\
\text { e }\end{array}$ & 1 \\
\hline \multirow[t]{7}{*}{$\begin{array}{l}\text { Conseqüência } \\
\text { (Reação dos } \\
\text { filhos) }\end{array}$} & $\begin{array}{l}\text { Problema do filho } \\
\text { (reação agressiva) }\end{array}$ & $\begin{array}{l}\text { Agressivo } \\
\text { verbalmente, não } \\
\text { aceita }\end{array}$ & 2 & & \\
\hline & & $\begin{array}{l}\text { Não demonstra } \\
\text { interesse }\end{array}$ & 1 & & \\
\hline & & Muda de assunto & 1 & & \\
\hline & $\begin{array}{l}\text { Problema do filho } \\
\text { (reação apática) }\end{array}$ & Não fala nada & 2 & $\begin{array}{l}\text { Não fala } \\
\text { nada }\end{array}$ & 1 \\
\hline & HS dos filhos & Justifica & 1 & $\begin{array}{l}\text { Fala de } \\
\text { novos } \\
\text { assuntos }\end{array}$ & 1 \\
\hline & & $\begin{array}{l}\text { Conversa mostrando } \\
\text { interesse }\end{array}$ & 8 & $\begin{array}{l}\text { Conversa } \\
\text { mostrando } \\
\text { interesse }\end{array}$ & 9 \\
\hline & & & & $\begin{array}{l}\text { Conversa e } \\
\text { dá } \\
\text { conselhos }\end{array}$ & 1 \\
\hline
\end{tabular}

Conforme a Tabela 17, as mães do grupo de risco conversam diante de problemas externalizantes como mentiras por parte dos filhos, irritabilidade dos mesmos e pelo fato dos adolescentes não terem feito a lição escolar, o que não acontece no grupo de não risco. Como citado anteriormente, esta interação no grupo de risco pode estar relacionada aos comportamentos problemáticos dos filhos de não aceitar o que a mãe fala, reagir de forma agressiva, conversar sem demonstrar interesse ou não falar nada.

Os assuntos conversados pelas mães do grupo de não risco são mais diversificados como amizades, escola, futuro profissional, programas de televisão, brincadeiras, namoro, orkut, tecnologias, respeito, religião e sexualidade, conforme mostra a Tabela 17. Já no grupo de risco, apesar das mães conversarem sobre assuntos diversos, isto ocorre com menor frequência, e há a maior incidência de conversar diante de problemas de comportamento externalizantes dos filhos.

Conversar sobre concepções de certo errado obteve a mesma frequência em ambos os grupos, mas no grupo de risco as mães citam os externalizantes dos quais se queixaram anteriormente como mentiras, drogas, problemas na escola e problemas de comportamento do filho.

Os filhos do grupo de não risco mostram-se habilidosos através de comportamentos como conversar mostrando interesse, dar conselhos para as mães e falar de novos assuntos. Os adolescentes do grupo de risco também possuem habilidades sociais, como conversar e justificar o seu ponto de vista, mas adicionalmente apresentam problemas de comportamento detectados pelas mães, o que não ocorre nos adolescentes do grupo de não risco. 
Quanto à subcategoria faz perguntas, os dados estão apresentados de forma geral na Figura 2.

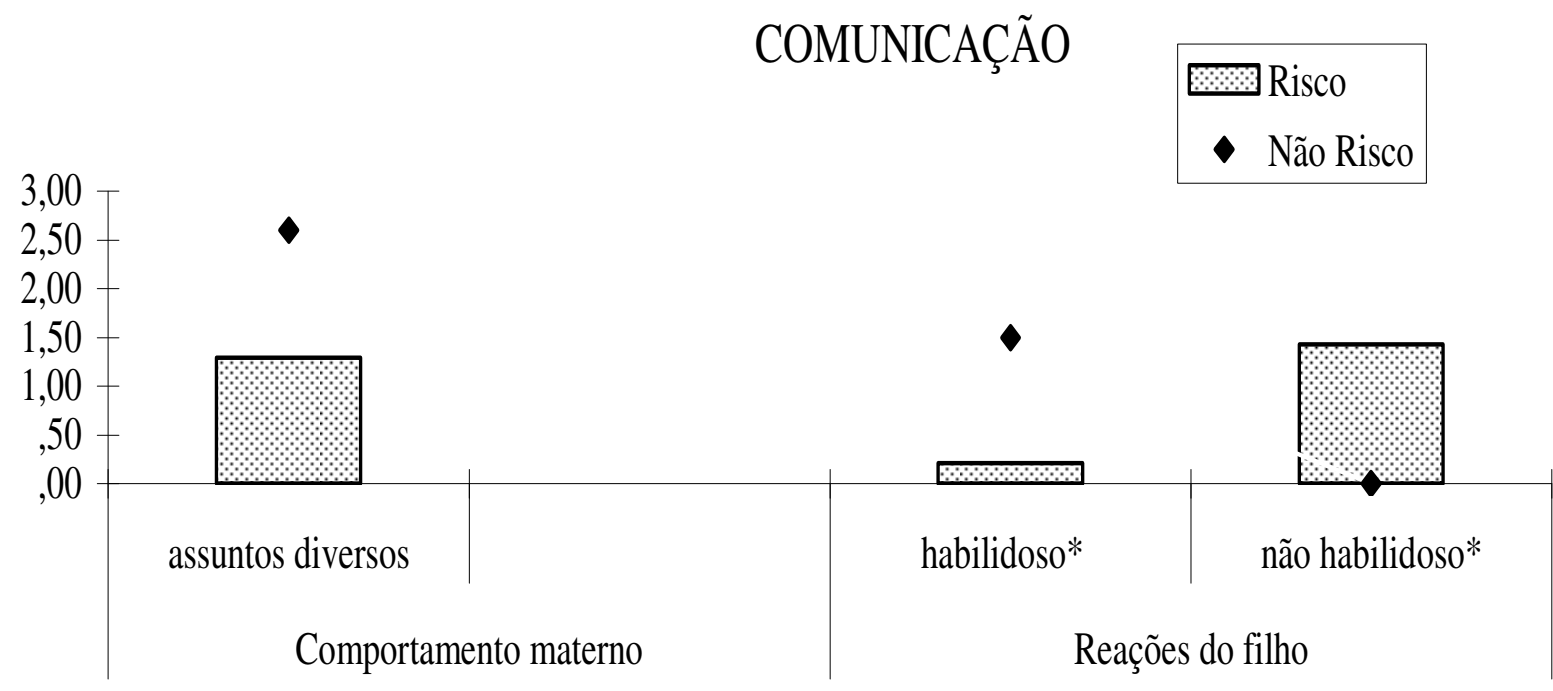

Faz perguntas

Figura 2 - Comparação entre amostra de risco e não risco sobre a frequência da subcategoria faz perguntas, das Habilidades Sociais Educativas Parentais (HSE-P) de comunicação. As diferenças estatísticas significantes estão representadas pelos asteriscos *.

Na subcategoria faz perguntas há diferenças significativas entre os grupos, como pode ser visto na Figura 2. Os adolescentes de não risco apresentam maior frequência de habilidades sociais (média risco $=0,21 /$ média não risco $=1,5$ e $p=0,00$ ) e ausência de problemas de comportamento (média risco $=1,43$ / média não risco $=0$ e p=0,00), sugerindo que os filhos do grupo de não risco incentivam as mães a perguntarem; diferentemente dos adolescentes do grupo de risco que apresentam menor incidência de habilidades sociais e maior de problemas de comportamento. Em relação aos temas das perguntas, isto é, assuntos sobre os quais as mães perguntam como obrigações, atividades do dia, família, os grupos não apresentam diferenças significativas (média risco $=1,29$ / média não risco $=2,6$ e p=0,12).

Para maior detalhamento dos comportamentos encontrados na subcategoria faz perguntas, foi elaborada a Tabela 18 contendo a descrição dos comportamentos emitidos pelas mães e filhos de ambos os grupos. 
Tabela 18 - Descrição e frequência dos comportamentos apresentados pelas mães e filhos de ambos os grupos na subcategoria faz perguntas.

\begin{tabular}{|c|c|c|c|c|c|}
\hline Faz perguntas & & Risco & Frequência & Não risco & Frequência \\
\hline \multirow{10}{*}{$\begin{array}{l}\text { Contingências } \\
\text { nas quais } \\
\text { ocorrem os } \\
\text { comportamentos } \\
\text { maternos de } \\
\text { fazer perguntas }\end{array}$} & \multirow[t]{10}{*}{ Contexto } & Atividades do dia & 3 & Atividades do dia & 6 \\
\hline & & Cigarro & 1 & Computador & 1 \\
\hline & & Drogas, maconha & 2 & Passeios & 1 \\
\hline & & Namoro, paquera & 2 & Namoro, paquera & 1 \\
\hline & & Obrigações escolares & 3 & Escola & 7 \\
\hline & & $\begin{array}{l}\text { Relacionamentos com } \\
\text { colegas }\end{array}$ & 6 & Relacionamentos com colegas & 7 \\
\hline & & Sexo & 1 & Relações com professores & 3 \\
\hline & & & & $\begin{array}{l}\text { Antes de perguntar, mãe } \\
\text { observa }\end{array}$ & 1 \\
\hline & & & & $\begin{array}{l}\text { Quando percebe que filha está } \\
\text { triste }\end{array}$ & 1 \\
\hline & & & & Filmes que filha viu & 1 \\
\hline \multirow{11}{*}{$\begin{array}{l}\text { Consequências } \\
\text { (reação dos } \\
\text { filhos) }\end{array}$} & \multirow{8}{*}{$\begin{array}{l}\text { Problema } \\
\text { dos } \\
\text { filhos }\end{array}$} & $\begin{array}{l}\text { Reage de forma agressiva, } \\
\text { grita }\end{array}$ & 2 & & \\
\hline & & Fica quieto, não fala nada & 5 & & \\
\hline & & Chora & 1 & & \\
\hline & & Nega & 1 & & \\
\hline & & Mente & 2 & & \\
\hline & & $\begin{array}{l}\text { Responde com pouco } \\
\text { interesse, diz não sei, ou diz } \\
\text { que está tudo certo. }\end{array}$ & 5 & & \\
\hline & & Muda de assunto & 3 & & \\
\hline & & $\begin{array}{l}\text { Não fala nada, pois sabe que } \\
\text { a mãe vai proibir }\end{array}$ & 1 & & \\
\hline & \multirow[t]{3}{*}{$\begin{array}{l}\text { HS dos } \\
\text { filhos }\end{array}$} & $\begin{array}{l}\text { Responde com interesse e } \\
\text { bom humor }\end{array}$ & 3 & $\begin{array}{l}\text { Responde com interesse e } \\
\text { bom humor }\end{array}$ & 8 \\
\hline & & & & Fala de outros assuntos & 4 \\
\hline & & & & Concorda & 1 \\
\hline
\end{tabular}

Quanto às contingências que influenciam o comportamento materno de fazer perguntas, nota-se que as mães do grupo de risco fazem mais perguntas relacionadas às preocupações com problemas de comportamento dos filhos, como pode ser visto na Tabela 18, quando as mães perguntam sobre drogas, maconha, cigarro, obrigações escolares e sexo; comportamento o qual não foi relatado pelas mães do grupo de não risco.

Os filhos do grupo de risco apresentam comportamentos problemáticos ao responderem perguntas maternas de forma agressiva, gritando, mentindo ou falando de forma desinteressada, mudando de assunto ou simplesmente não respondendo as perguntas feitas pelas mães. Os adolescentes do grupo de não risco além de não apresentarem tais problemas, apresentam habilidades sociais ao responderem as perguntas maternas com interesse, bom humor, acrescentando novos assuntos na conversação e concordando com as mães.

Quanto à subcategoria faz perguntas de sexualidade, os dados estão apresentados de forma geral na Figura 3. 


\section{COMUNICAÇÃO}

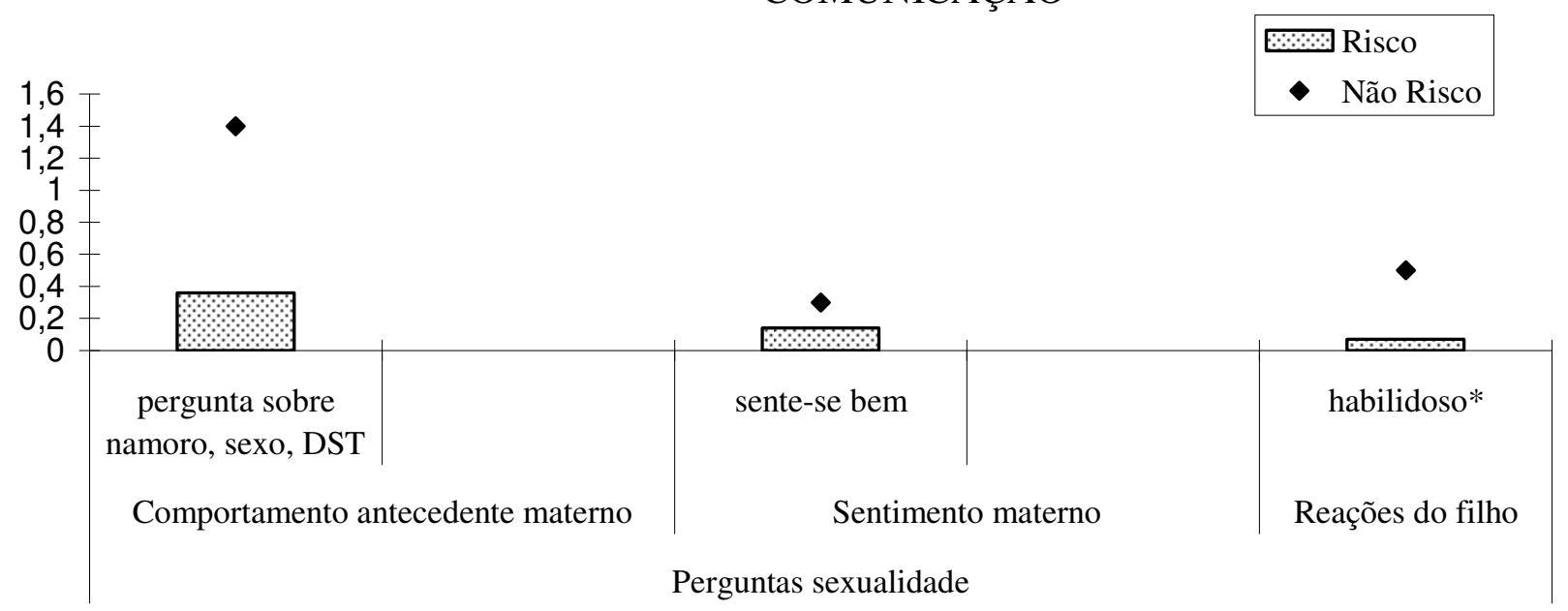

Figura 3 - Comparação entre amostra de risco e não risco sobre a frequência da subcategoria faz perguntas de sexualidade, das Habilidades Sociais Educativas Parentais (HSE-P) de comunicação. As diferenças estatísticas significantes estão representadas pelos asteriscos *.

Na subcategoria faz perguntas de sexualidade (Figura 3), os adolescentes da amostra de não risco agem de forma mais habilidosa para conversar sobre estes assuntos (média risco $=0,07 /$ média não risco $=0,5 \mathrm{e} \mathrm{p}=0,05)$, fazem mais perguntas sobre o tema que os adolescentes do grupo de risco.

Apesar das mães do grupo de não risco apresentarem maior frequência de comportamentos comunicativos sobre sexualidade, ambos os grupos apresentam frequência relativamente baixa de comunicação sobre o tema, sem diferença estatística significativa entre os grupos no que se refere a perguntas por parte das mães sobre namoro, DST, sexo (média risco $=0,36 /$ média não risco $=1,4$ e $\mathrm{p}=0,08$ ). Bem como foi pouco frequente às mães, de ambos os grupos, se sentirem bem ao falar sobre esse assunto (média risco $=0,14$ / média não risco $=0,3$ e $\mathrm{p}=0,36)$.

Para detalhamento dos comportamentos encontrados na subcategoria faz perguntas de sexualidade, foi elaborada a Tabela 19 contendo a descrição dos comportamentos emitidos pelas mães e filhos de ambos os grupos. 
Tabela 19 - Descrição e frequência dos comportamentos apresentados pelas mães e filhos de ambos os grupos na subcategoria faz perguntas de sexualidade.

\begin{tabular}{|c|c|c|c|c|c|}
\hline $\begin{array}{l}\text { Perguntas de } \\
\text { sexualidade }\end{array}$ & & Risco & Frequência & Não risco & Frequência \\
\hline $\begin{array}{l}\text { Antecedentes } \\
\text { maternos }\end{array}$ & HSE-P & Sente-se bem & 2 & Sente-se bem & 3 \\
\hline \multirow{7}{*}{$\begin{array}{l}\text { Contingências do } \\
\text { comportamento } \\
\text { materno }\end{array}$} & \multirow{7}{*}{$\begin{array}{l}\text { Contexto- } \\
\text { Assuntos } \\
\text { sobre os } \\
\text { quais mães } \\
\text { perguntam }\end{array}$} & Menstruação & 1 & Menstruação & 1 \\
\hline & & Corpo feminino & 1 & Casamento & 1 \\
\hline & & Namoro & 1 & Namoro & 4 \\
\hline & & Relação sexual & 1 & Relação sexual & 3 \\
\hline & & $\begin{array}{l}\text { Métodos de prevenção } \\
\text { (camisinha/ } \\
\text { anticoncepcional) }\end{array}$ & 1 & $\begin{array}{l}\text { Métodos de prevenção } \\
\text { (camisinha/ } \\
\text { anticoncepcional) }\end{array}$ & 2 \\
\hline & & & & Gestação & 2 \\
\hline & & & & Higiene & 1 \\
\hline \multirow{2}{*}{$\begin{array}{l}\text { Reação dos } \\
\text { filhos }\end{array}$} & \multirow{2}{*}{$\begin{array}{l}\text { HS do } \\
\text { filho }\end{array}$} & Faz novas perguntas & 1 & Faz novas perguntas & 4 \\
\hline & & & & Ouve atentamente & 1 \\
\hline
\end{tabular}

Conforme a Tabela 19, as mães de ambos os grupos com pouca frequência se sentem bem para falar sobre sexualidade. Os temas conversados em ambos os grupos envolvem temas semelhantes, como falar sobre menstruação, namoro, relação sexual e métodos de prevenção. E os filhos do grupo de não risco fazem mais perguntas sobre o assunto que os de risco.

A categoria expressão de sentimentos e enfrentamento é composta pela expressão de sentimentos negativos, positivos, opiniões e afeto através do carinho. No que diz respeito à subcategoria expressão de sentimentos negativos, os dados estão apresentados, de forma geral, na Figura 4. 


\section{EXPRESSÃO DE SENTIMENTOS E ENFRENTAMENTO}
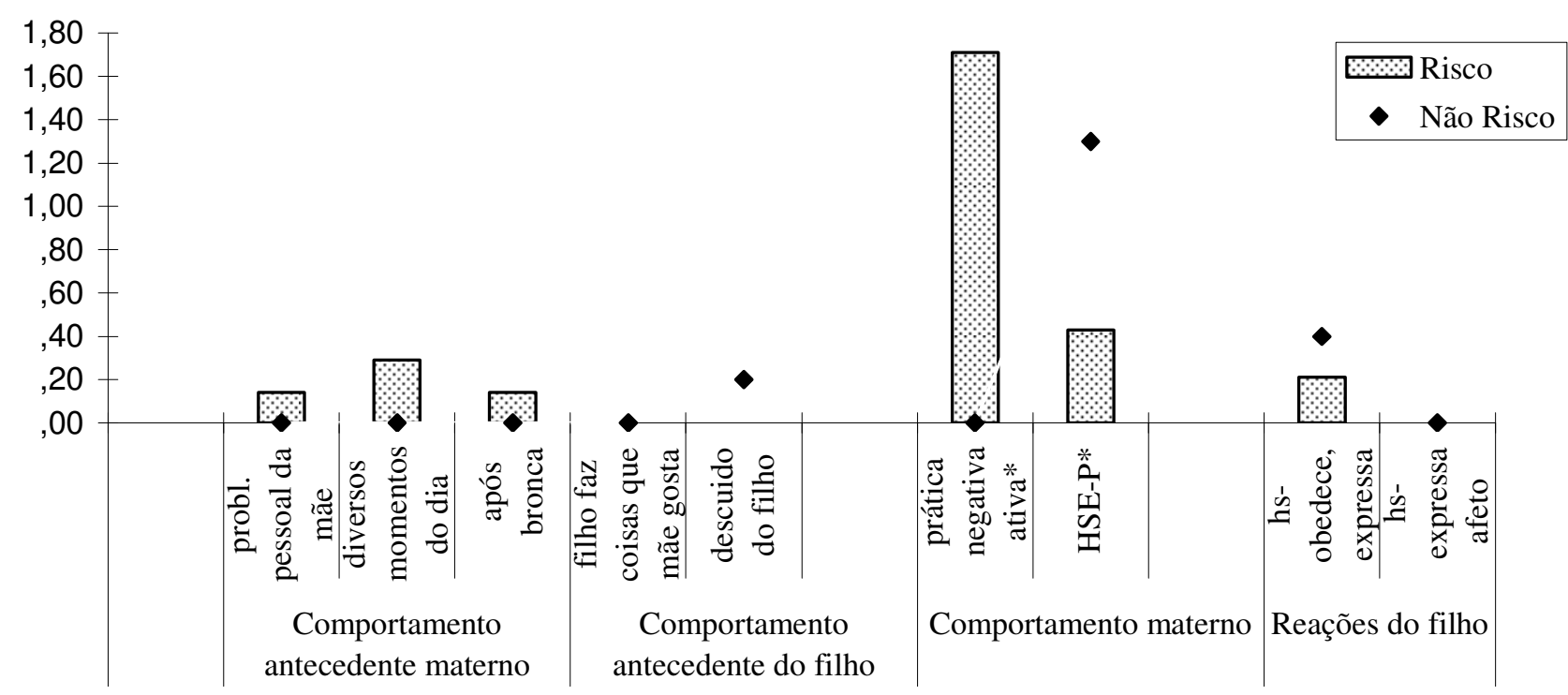

Expressão de sentimentos negativos

Figura 4 - Comparação entre amostra de risco e não risco sobre a frequência da subcategoria expressa sentimentos negativos, das Habilidades Sociais Educativas Parentais (HSE-P) de expressão de sentimentos e enfrentamento. As diferenças estatísticas significantes estão representadas pelos asteriscos *.

Como mostra a Figura 4, em relação ao comportamento materno para expressão de sentimentos negativos, as mães do grupo de risco apresentam maior frequência de práticas negativas ativas que as de não risco, as quais não apresentam práticas negativas (média risco $=1,71$ /média não risco $=0)$, com diferença significativa entre os grupos $(\mathrm{p}=0,02)$. As mães do grupo de não risco agem de forma mais habilidosa, falando e conversando para expressar sentimentos negativos, havendo diferença estatística entre os grupos em relação às habilidades sociais educativas maternas (média risco $=0,43$ / média não risco $=1,3$ e p=0,01).

Com relação aos antecedentes do comportamento materno relacionados ao próprio comportamento, a expressão de sentimentos negativos por problemas pessoais das mães foi nula na população de não risco e de baixa frequência na de risco, sem diferença significativa entre os grupos (média risco $=0,14 /$ média não risco $=0$ e $\mathrm{p}=0,22$ ). A expressão de sentimentos negativos maternos em diversos momentos do dia foi nula no grupo de não risco e de baixa frequência no de risco, sem diferença estatística significativa entre os grupos (média risco $=0,29$ / média não risco $=0$ e $\mathrm{p}=0,39$ ). As mães do grupo de não risco não expressam sentimentos negativos após as broncas, assim como as do grupo de risco fizeram com baixa frequência, sendo que a diferença entre os grupos não foi significativa (média risco $=0,14$ / média não risco $=0$ e $\mathrm{p}=0,22$ ). 
Sobre os antecedentes do comportamento materno relacionados ao comportamento dos filhos, a expressão de sentimentos negativos por descuido do filho com o ambiente foi nula no grupo de risco e de baixa frequência no grupo de não risco, sem diferença entre os grupos (média risco $=0 /$ média não risco $=0,2 \mathrm{e} \mathrm{p}=0,08$ ). $\mathrm{O}$ comportamento dos adolescentes de fazer coisas que as mães gostam em situações de expressão de sentimentos negativos das mães foi nula em ambos os grupos. As mães do grupo de não risco não expressam sentimentos negativos após as broncas, assim como as do grupo de risco fizeram com baixa frequência, sendo que a diferença entre os grupos não foi significativa (média risco $=0,14$ / média não risco $=0$ e $\mathrm{p}=0,22$ ).

As habilidades sociais dos adolescentes de obedecer, reivindicar seus direitos e explicar o seu ponto de vista após a expressão de sentimentos negativos por parte das mães, foram semelhantes para ambos os grupos, sem diferença estatística significante (média risco = 0,21 / média não risco $=0,4$ e p=0,38); a habilidade de expressar afeto para com a mãe após a expressão de sentimentos negativos das mães foi nula em ambos os grupos (média risco $=0$ / média não risco $=0$ e $\mathrm{p}=1$ ).

Para análise mais detalhada dos comportamentos encontrados na subcategoria expressão de sentimentos negativos foi elaborada a Tabela 20 contendo a descrição dos comportamentos emitidos pelas mães e pelos filhos de ambos os grupos.

Tabela 20 - Descrição e frequência dos comportamentos apresentados pelas mães e filhos de ambos os grupos na subcategoria expressa sentimentos negativos.

\begin{tabular}{|c|c|c|c|c|c|}
\hline \multicolumn{2}{|c|}{ Expressão de sentimentos negativos } & \multirow{2}{*}{$\begin{array}{l}\text { Risco } \\
\text { Ambiente } \\
\text { desarrumado }\end{array}$} & \multirow{2}{*}{$\begin{array}{l}\text { Frequência } \\
1\end{array}$} & \multirow{2}{*}{$\begin{array}{l}\text { Não risco } \\
\text { Ambiente } \\
\text { desarrumado }\end{array}$} & \multirow{2}{*}{$\frac{\text { Frequência }}{2}$} \\
\hline $\begin{array}{l}\text { Antecedentes } \\
\text { do }\end{array}$ & Problema dos filhos & & & & \\
\hline comportamento & Contexto & Não estuda & 3 & & \\
\hline materno & $\begin{array}{l}\text { (Situações na qual a } \\
\text { mãe expressa }\end{array}$ & $\begin{array}{l}\text { Para desligar } \\
\text { computador }\end{array}$ & 1 & & \\
\hline & sentimentos & Tomar banho & 1 & & \\
\hline & negativos) & $\begin{array}{l}\text { Dificuldades com } \\
\text { horários }\end{array}$ & 1 & & \\
\hline & $\begin{array}{l}\text { Prática negativa } \\
\text { materna }\end{array}$ & $\begin{array}{l}\text { Quando não obedece } \\
\text { as ordens }\end{array}$ & 1 & & \\
\hline $\begin{array}{l}\text { Comportamento } \\
\text { materno }\end{array}$ & Prática negativa & $\begin{array}{l}\text { Manda o filho se } \\
\text { ferrar }\end{array}$ & 1 & & \\
\hline & & Grita & 7 & & \\
\hline & & Bate & 4 & & \\
\hline & & Ameaça castigá-lo & 1 & & \\
\hline & & Ameaça batê-lo & 1 & & \\
\hline & & $\begin{array}{l}\text { Critica todos os pontos } \\
\text { negativos do filho }\end{array}$ & 2 & & \\
\hline & & Humilha o filho & 1 & & \\
\hline & & $\begin{array}{l}\text { Xinga o filho de } \\
\text { vagabundo, de mula }\end{array}$ & 2 & & \\
\hline & & $\begin{array}{l}\text { Filho não pode chegar } \\
\text { perto }\end{array}$ & 1 & & \\
\hline
\end{tabular}




\begin{tabular}{|c|c|c|c|c|c|}
\hline & & Quando estou nervosa & \multicolumn{3}{|l|}{5} \\
\hline & \multirow[t]{3}{*}{ HSE-P } & \multirow[t]{3}{*}{ Falando, conversando } & \multirow[t]{3}{*}{6} & $\begin{array}{l}\text { Falando, } \\
\text { conversando }\end{array}$ & 10 \\
\hline & & & & Explicando & 7 \\
\hline & & & & $\begin{array}{l}\text { Auxiliando o } \\
\text { filho a } \\
\text { analisar o } \\
\text { próprio } \\
\text { comportamen } \\
\text { to }\end{array}$ & 2 \\
\hline \multirow{3}{*}{$\begin{array}{l}\text { Comportamento } \\
\text { dos filhos }\end{array}$} & \multirow{3}{*}{ HS do filho } & Obedece & 1 & Obedece & 1 \\
\hline & & Escuta & 1 & $\begin{array}{l}\text { Explica o que } \\
\text { houve }\end{array}$ & 1 \\
\hline & & $\begin{array}{l}\text { Reivindica seus } \\
\text { direitos }\end{array}$ & 1 & $\begin{array}{l}\text { Reivindica } \\
\text { seus direitos }\end{array}$ & 2 \\
\hline
\end{tabular}

Conforme mostra a Tabela 20, nota-se que os antecedentes do comportamento materno para expressão de sentimentos negativos no grupo de risco são em grande frequência problemas de comportamento dos filhos, como o fato do filho não estudar, ter dificuldades com horários, a mãe ter que insistir para o filho tomar banho e o filho deixar os ambientes desarrumados, único item que também apareceu no grupo de não risco.

E para expressar o sentimento negativo, neste tipo de situação, as mães da amostra de risco agem de forma agressiva gritando, xingando, expressando todos os pontos negativos do filho, ameaçando de castigo ou de punição física e humilhando o adolescente; comportamentos classificados como prática negativa ativa. Comportamentos negativos ativos são ausentes na amostra de não risco, na qual as mães buscam conversar, explicar para o filho o porquê do desagrado, bem como algumas buscam estimular o filho a analisar as consequências do próprio comportamento. As mães do grupo de risco também relatam conversar neste tipo de interação, mas com menor frequência e, adicionalmente, agindo agressivamente.

Quanto à subcategoria expressão de sentimentos positivos, os dados estão apresentados, de forma geral, na Figura 5. 


\section{EXPRESSÃO DE SENTIMENTOS E ENFRENTAMENTO}

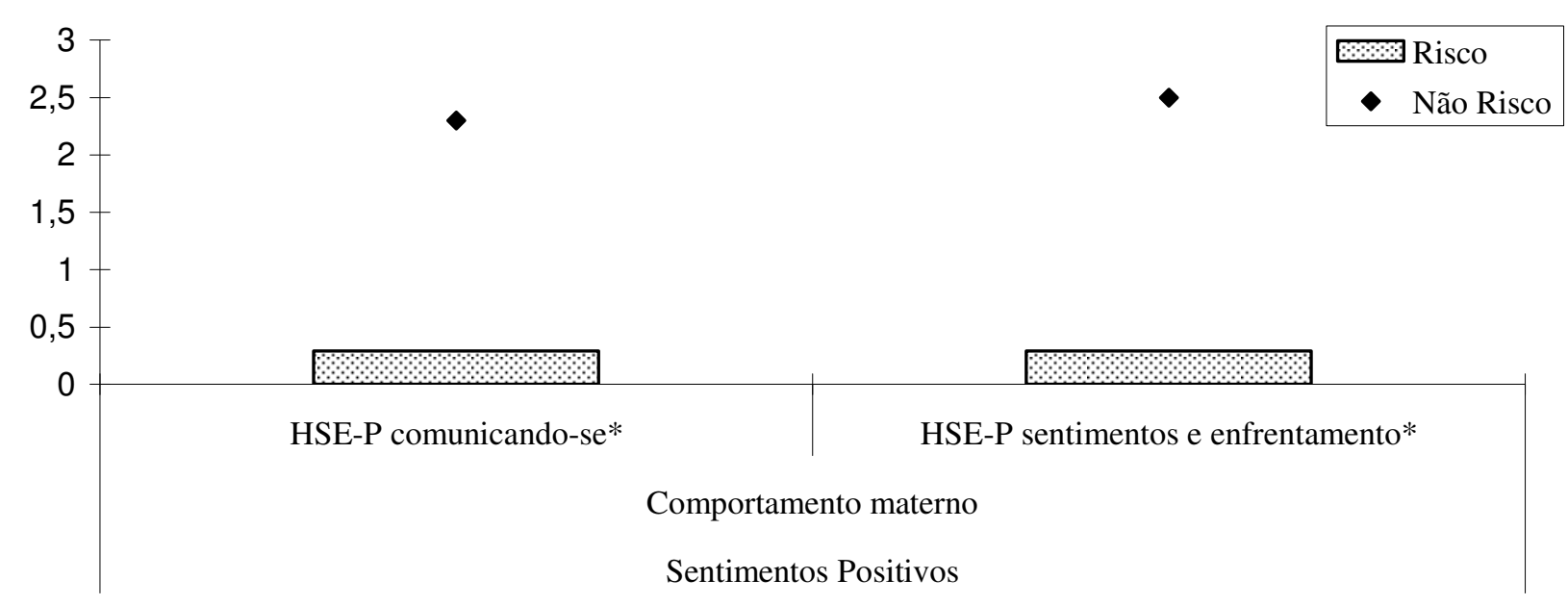

Figura 5 - Comparação entre amostra de risco e não risco sobre a frequência da subcategoria expressão de sentimentos positivos, das Habilidades Sociais Educativas Parentais (HSE-P) de expressão de sentimentos e enfrentamento. As diferenças estatísticas significantes estão representadas pelos asteriscos *.

A expressão de sentimentos positivos é mais presente no grupo de não risco que no de risco em todos os aspectos avaliados, conforme mostra a Figura 5. As mães de não risco expressam mais sentimentos positivos através da comunicação, prestando atenção, falando, conversando e elogiando seus filhos (média risco $=0,29 /$ média não risco $=2,3$ e p=0,00). Bem como as mães de não risco relatam agir de forma a agradar e fazer carinho (sentimentos e enfrentamento) com mais frequência que as de risco (média risco $=0,29$ / média não risco $=$ $2,3$ e $\mathrm{p}=0,00)$.

Para maior detalhamento dos comportamentos encontrados na subcategoria expressão de sentimentos positivos foi elaborada a Tabela 21, contendo a descrição dos comportamentos emitidos pelas mães e filhos de ambos os grupos.

Tabela 21 - Descrição e frequência dos comportamentos apresentados pelas mães e filhos de ambos os grupos na subcategoria expressa sentimentos positivos.

\begin{tabular}{|c|c|c|c|c|c|}
\hline \multicolumn{2}{|c|}{ Expressão de sentimentos positivos } & Risco & Frequência & Não risco & Frequência \\
\hline \multirow[t]{12}{*}{ Comportamento materno } & \multirow{8}{*}{$\begin{array}{l}\text { HSE-P } \\
\text { (Afeto- } \\
\text { expressão de } \\
\text { sentimentos e } \\
\text { enfrentamento) }\end{array}$} & Agradando & 1 & Agradando & 6 \\
\hline & & Fazendo carinho & 1 & Fazendo carinho & 3 \\
\hline & & Abraçando & 2 & Abraçando & 6 \\
\hline & & & & Elogiando & 6 \\
\hline & & & & Beijando & 3 \\
\hline & & & & Dando a mão & 1 \\
\hline & & & & Cuidando & 1 \\
\hline & & & & $\begin{array}{l}\text { Prestando } \\
\text { atenção }\end{array}$ & 1 \\
\hline & \multirow{4}{*}{$\begin{array}{l}\text { HSE-P } \\
\text { (Comunicação) }\end{array}$} & Falando & 6 & Falando & 7 \\
\hline & & & & Valorizando & 1 \\
\hline & & & & Brincando & 3 \\
\hline & & & & Passeando & 4 \\
\hline
\end{tabular}


Conforme a Tabela 21, a variabilidade e a frequência do comportamento materno no grupo de não risco para expressão de sentimentos positivos é maior, tanto na expressão de sentimentos e enfrentamento, quanto na comunicação. Através de comportamentos maternos como agradar, fazer carinho, abraçar, elogiar, beijar, dar as mãos, cuidar, prestar atenção no filho, falar, valorizar, brincar e passear. Tendo em vista que no grupo de risco os comportamentos são mais restritos e menos frequentes na expressão de sentimentos positivos.

Com relação à subcategoria expressão de opiniões, elaborou-se a Figura 6.

\section{EXPRESSÃO DE SENTIMENTOS E ENFRENTAMENTO}

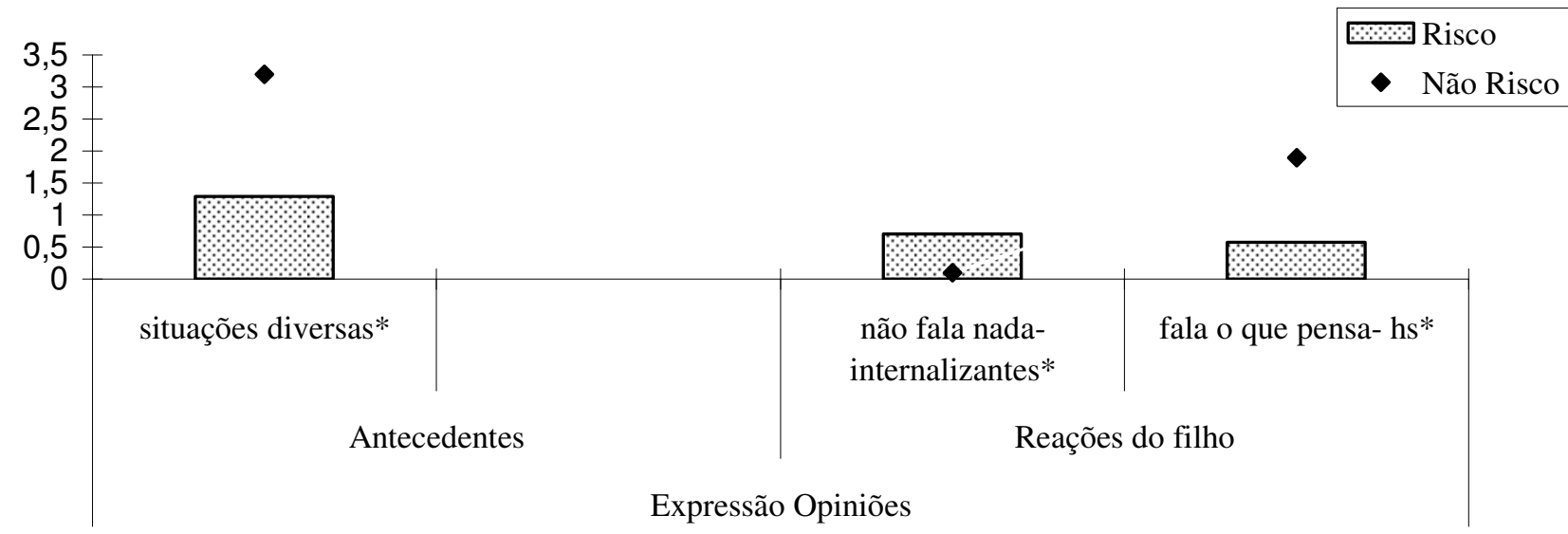

Figura 6 - Comparação entre amostra de risco e não risco sobre a frequência da subcategoria expressão de opiniões, das Habilidades Sociais Educativas Parentais (HSE-P) de expressão de sentimentos e enfrentamento. As diferenças estatísticas significantes estão representadas pelos asteriscos *.

$\mathrm{Na}$ expressão de opiniões, tanto as mães quanto os filhos da amostra de não risco apresentam maior frequência de habilidades sociais, como mostra a Figura 6. A expressão de opiniões em situações diversas é mais frequente entre as mães de não risco que entre as de risco (média risco $=1,29$ / média não risco $=3,2$ e $\mathrm{p}=0,00$ ). As reações dos filhos de não risco são mais habilidosas que entre os adolescentes do grupo de risco (média risco $=0,57$ / média não risco $=1,9$ e p $=0,00$ ), através da explicação do seu ponto de vista, da apresentação de bons argumentos e da obediência, mesmo na exposição de opiniões.

Os adolescentes do grupo de risco apresentam maior frequência de problemas internalizantes como: ouvir a opinião da mãe e não dizer nada ou não gostar (média risco = 0,7 / média não risco $=0,1$ e p=0,03).

Para análise dos comportamentos encontrados na subcategoria expressão de opiniões, foi elaborada a Tabela 22 contendo a descrição dos comportamentos emitidos pelas mães e filhos de ambos os grupos. 
Tabela 22 - Descrição e frequência dos comportamentos apresentados pelas mães e filhos de ambos os grupos na subcategoria expressão de opiniões.

\begin{tabular}{|c|c|c|c|c|c|}
\hline \multicolumn{2}{|c|}{ Expressão de opiniões } & Risco & Frequência & Não risco & Frequência \\
\hline \multirow{9}{*}{$\begin{array}{l}\text { Contingências- } \\
\text { temas de } \\
\text { assuntos na } \\
\text { expressão de } \\
\text { opiniões }\end{array}$} & \multirow[t]{9}{*}{ Contexto } & Discriminação racial & 1 & Relações com adultos & 2 \\
\hline & & Computador & 1 & Ao assistir TV & 3 \\
\hline & & Sobre o que é certo e errado & 3 & Sobre o que é certo e errado & 8 \\
\hline & & Relações com amigos & 7 & Relações com amigos & 7 \\
\hline & & Roupas & 2 & Roupas & 6 \\
\hline & & Estética & 1 & Drogas, bebidas & 1 \\
\hline & & Sexo & 1 & Riscos da vida & 1 \\
\hline & & Respeito ao próximo & 1 & & \\
\hline & & Trabalho & 1 & & \\
\hline \multirow{8}{*}{$\begin{array}{l}\text { Comportamentos } \\
\text { dos filhos } \\
\text { (reações) }\end{array}$} & \multirow{3}{*}{$\begin{array}{l}\text { HS dos } \\
\text { filhos }\end{array}$} & Ouve & 1 & Tem bons argumentos & 2 \\
\hline & & Concorda e obedece & 2 & Concorda e obedece & 5 \\
\hline & & Explica, expressa sua opinião & 4 & $\begin{array}{l}\text { Explica, expressa sua } \\
\text { opinião }\end{array}$ & 10 \\
\hline & \multirow{5}{*}{$\begin{array}{l}\text { Problema } \\
\text { dos } \\
\text { filhos }\end{array}$} & $\begin{array}{l}\text { Teimosa, não aceita a opinião da } \\
\text { mãe }\end{array}$ & 1 & & \\
\hline & & Não diz nada & 6 & \multirow[t]{4}{*}{ Não diz nada } & \multirow[t]{4}{*}{1} \\
\hline & & Muda de assunto & 1 & & \\
\hline & & Diz que não consegue & 1 & & \\
\hline & & Expressão de que não está nem aí & 1 & & \\
\hline
\end{tabular}

Os temas de referência para expressão de opiniões são os mais diversos em ambos os grupos, conforme mostra a Tabela 22. No entanto, as reações dos filhos do grupo de não risco são mais habilidosas ao explicar suas opiniões, concordar e apresentar bons argumentos, bem como não apresentam problemas de comportamento, os quais são detectados nos adolescentes do grupo de risco, os quais segundo as mães agem de forma teimosa, mudam de assunto, dão a entender que não se importam com a opinião da mãe, de forma a desprezar o comportamento materno.

No que diz respeito à expressão de carinho, a Figura 7 apresenta os resultados encontrados de forma geral. 


\section{EXPRESSÃO DE SENTIMENTOS E ENFRENTAMENTO}
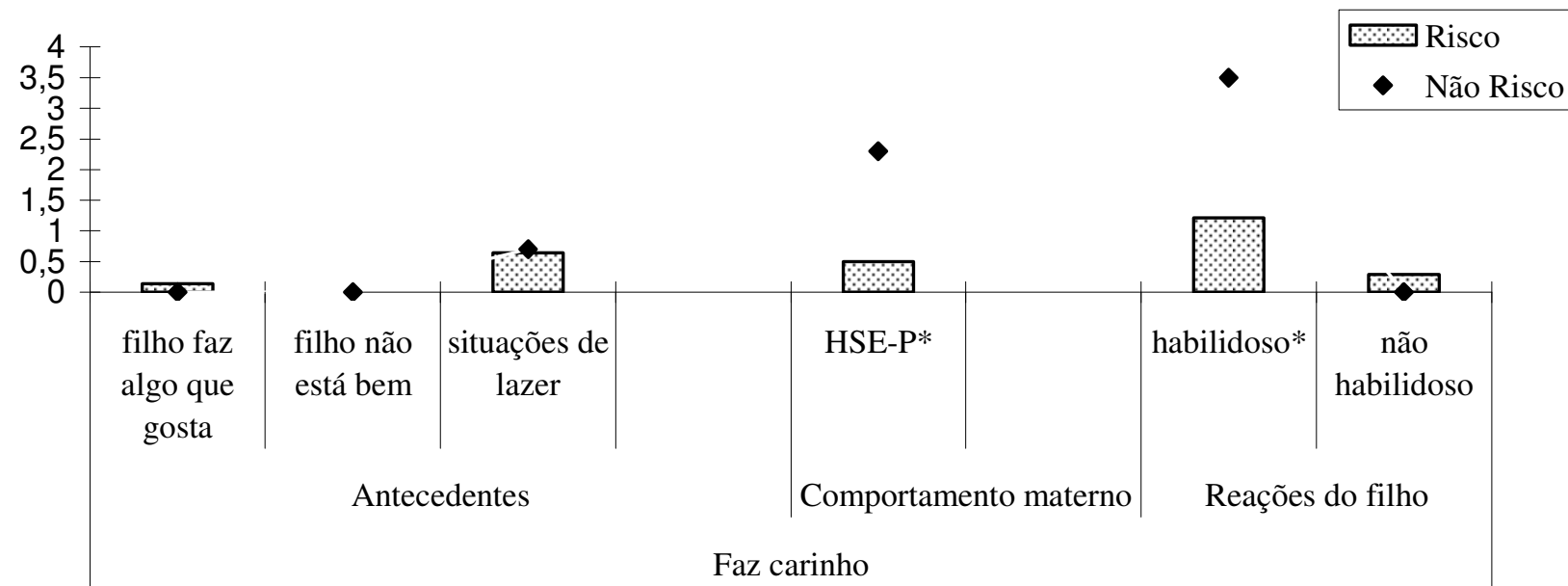

Figura 7 - Comparação entre amostra de risco e não risco sobre a frequência da subcategoria expressão de carinho, das Habilidades Sociais Educativas Parentais (HSE-P) de expressão de sentimentos e enfrentamento. As diferenças estatísticas significantes estão representadas pelos asteriscos *.

Sobre a habilidade de expressar carinho, tanto os adolescentes quanto as mães de não risco agem de forma mais afetuosa. De forma geral as mães de não risco agem habilidosamente tanto verbal quanto não verbalmente (HSE-P), dizendo que amam, abraçando, beijando os seus filhos com maior frequência que as de risco (média risco $=0,86$ / média não risco $=1,2$ e $\mathrm{p}=0,00)$. Assim como os adolescentes do grupo de não risco apresentam maior disponibilidade e cooperação (HS) que os do grupo de risco (média risco $=1,21$ /média não risco $=3,5$ e p=0,00).

O comportamento da mãe de fazer carinho quando o filho faz coisas que ela gosta ( média risco $=0,14$ / média não risco $=0$ e p $=0,22$ ), em situações de lazer (média risco $=0,64$ / média não risco $=0,7$ e $\mathrm{p}=0,71$ ) ou quando o filho não está bem (média risco $=0$ / média não risco $=0$ e $\mathrm{p}=1,00$ ) foram subcategorias que não apresentaram diferença estatística significativa na comparação entre os grupos. Assim como problemas de comportamento, isto é, reações não habilidosas dos filhos foram ausentes no grupo de não risco e pouco frequentes no grupo de risco (média risco $=0,29)$, sem diferença estatística entre os grupos $(\mathrm{p}=0,12)$.

Para análise detalhada dos comportamentos encontrados na subcategoria expressão de carinho, elaborou-se a Tabela 23 contendo a descrição dos comportamentos emitidos pelas mães e filhos de ambos os grupos. 
Tabela 23 - Descrição e frequência dos comportamentos apresentados pelas mães e filhos de ambos os grupos na subcategoria expressão de carinho.

\begin{tabular}{|c|c|c|c|c|c|}
\hline Faz carinho & & Risco & Frequência & Não risco & Frequência \\
\hline $\begin{array}{l}\text { Antecedentes do } \\
\text { comportamento materno }\end{array}$ & HS do filho & $\begin{array}{l}\text { Quando ele } \\
\text { age certo }\end{array}$ & 2 & & \\
\hline \multirow{4}{*}{$\begin{array}{l}\text { Contingências para } \\
\text { demonstração de carinho }\end{array}$} & \multirow{4}{*}{$\begin{array}{l}\text { Contexto no } \\
\text { qual as mães } \\
\text { demonstram } \\
\text { carinho }\end{array}$} & Ao ver TV & 1 & Ao ver TV & 1 \\
\hline & & $\begin{array}{l}\text { À noite, na } \\
\text { hora de } \\
\text { dormir }\end{array}$ & 4 & & \\
\hline & & $\begin{array}{l}\text { Sempre que } \\
\text { estão juntos }\end{array}$ & 2 & Sempre que estão juntos & 7 \\
\hline & & De manhã & 2 & De manhã & 1 \\
\hline \multirow{9}{*}{$\begin{array}{l}\text { Comportamento filho } \\
\text { (reação do filho) }\end{array}$} & \multirow[t]{6}{*}{ HS } & Retribui & 1 & Diz que ama, adora a mãe & 4 \\
\hline & & Beija & 1 & Beija & 7 \\
\hline & & Sorri & 3 & Sorri & 6 \\
\hline & & Abraça & 1 & Abraça & 2 \\
\hline & & & & Brinca & 1 \\
\hline & & & & Agradece & 4 \\
\hline & \multirow[t]{3}{*}{$\begin{array}{l}\text { Problema dos } \\
\text { filhos }\end{array}$} & $\begin{array}{l}\text { Evita, afasta- } \\
\text { se }\end{array}$ & 2 & & \\
\hline & & Tímida & 1 & & \\
\hline & & $\begin{array}{l}\text { Nega os } \\
\text { elogios }\end{array}$ & 1 & & \\
\hline \multirow[t]{9}{*}{ Reação das mães } & \multirow[t]{9}{*}{ HSE-P } & $\begin{array}{l}\text { Dança com o } \\
\text { filho }\end{array}$ & 1 & Brinca com a filha & 3 \\
\hline & & Toca o filho & 1 & Toca o filho & 5 \\
\hline & & Abraça & 7 & Abraça & 8 \\
\hline & & Beija & 2 & Beija & 2 \\
\hline & & Diz que ama & 2 & Diz que ama & 4 \\
\hline & & Pega no colo & 1 & Andam de mãos dadas & 2 \\
\hline & & $\begin{array}{l}\text { Apaga a luz } \\
\text { para dormir }\end{array}$ & 1 & Atende pedidos & 5 \\
\hline & & Elogia & 2 & Elogia & 6 \\
\hline & & & & Ajuda a filha & 1 \\
\hline
\end{tabular}

No que diz respeito aos antecedentes do comportamento materno para expressão de carinho, algumas mães do grupo de risco relataram que o filho precisa agir certo para que ela expresse afeto, conforme mostra a Tabela 23. As contingências para demonstração de carinho por parte das mães são semelhantes para ambos os grupos, ao demonstrarem carinho sempre, pela manhã, ao assistirem televisão ou à noite. As reações habilidosas dos filhos perante as demonstrações de carinho são mais frequentes no grupo de não risco através de comportamentos como dizer que ama e adora a mãe, sorrir, abraçar, beijar, brincar e agradecer a mãe, comportamentos que aparecem em menor frequência no grupo de risco.

Poucos adolescentes do grupo de risco apresentam problemas de comportamento como afastar-se, negar os elogios e agir de forma tímida na demonstração de carinho, o que não acontece no grupo de não risco. E as mães do grupo de não risco reagem com maior frequência habilidosamente nas demonstrações de afeto, apesar de ambos os grupos 
apresentarem topologias de comportamentos semelhantes, tais como brincar, tocar, abraçar, beijar, dizer que ama.

Quanto à categoria estabelecimento de limites, esta engloba estabelecer limites, identificar erros, fazer coisas que as mães gostam e fazer coisas que as mães não gostam.

Em relação à subcategoria estabelecer limites, a Figura 8 apresenta, de forma geral, os resultados encontrados.

\section{ESTABELECIMENTO DE LIMITES}

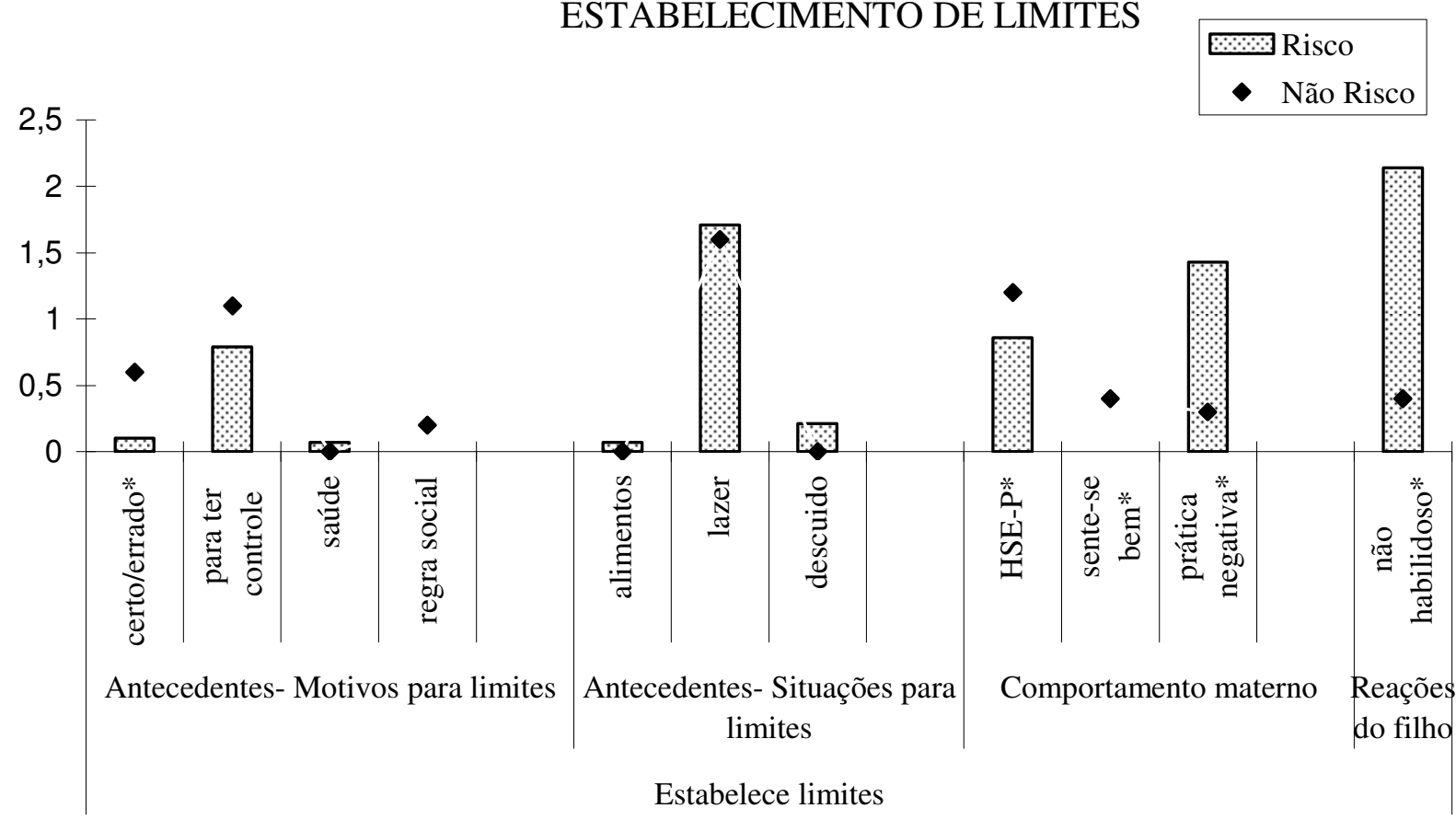

Figura 8 - Comparação entre amostra de risco e não risco sobre a frequência da subcategoria estabelecer limites, das Habilidades Sociais Educativas Parentais (HSE-P) de estabelecimento de limites. As diferenças estatísticas significantes estão representadas pelos asteriscos *.

Em estabelecimento de limites, como pode ser visto na Figura 8, as diferenças entre os grupos surgiram em relação ao motivo materno, para a aplicação de limites, em especial a apresentação das concepções de certo e errado aos filhos. Sendo mais frequente para o grupo de não risco impor limites para ensinar a distinção entre certo e errado (médias risco $=0,14$ / médias não risco $=0,6$ e $\mathrm{p}=0,02$ ) que no grupo de risco. As mães do grupo de não risco apresentam maior frequência de habilidades sociais educativas para estabelecimento de limites (média risco $=0,8$ / média não risco $=1,2$ e p $=0,01$ ) e sentem-se bem ao impor limites aos filhos (médias risco $=0$ / médias não risco $=0.4$ e p $=0,01$ ), o que não ocorre no grupo de risco.

As mães do grupo de risco apresentam maior frequência de práticas negativas passivas e ativas ao impor limites aos filhos (médias risco $=1,43$ / médias não risco $=0,3$ e p = 0,01). 
Assim como os filhos do grupo de risco apresentam maior incidência de problemas de comportamento ao receberem os limites por parte das mães (média risco $=2,14$ / não risco $=$ $0,4$ e $\mathrm{p}=0,00)$.

Os demais motivos maternos para aplicação de limites não apresentam diferenças significativas entre os grupos, como aplicação de limites por causa da saúde dos filhos (média risco $=0,07$ / média não risco $=0$ e p=0,39), para ter controle sobre o comportamento do filho (média risco $=0,79$ / média não risco $=1 \mathrm{e} p=0,06$ ) e por haver regras sociais em todas as esferas da vida (risco $=0$ / média não risco $=0,2$ e p $=0,08$ ).

A frequência para estabelecimento de limites em situações de lazer (horário para TV, vídeo-game, sair, brincadeiras, internet) é alta em ambos os grupos, mas sem diferença significativa (média risco $=1,71 /$ média não risco $=1,6$ e $\mathrm{p}=0,83$ ). Não há diferenças significativas entre os grupos com relação a estabelecer limites por causa da alimentação (média risco $=0,07 /$ média não risco $=0$ e $\mathrm{p}=0,39$ ) e descuido do filho com o ambiente e com as próprias coisas (média risco $=0,21$ / média não risco $=0$ e p=0,39).

Para análise dos comportamentos encontrados na subcategoria estabelecer limites, foi elaborada a Tabela 24 contendo a descrição dos comportamentos emitidos pelas mães e filhos de ambos os grupos. 
Tabela 24 - Descrição e frequência dos comportamentos apresentados pelas mães e filhos de ambos os grupos na subcategoria estabelecer limites.

\begin{tabular}{|c|c|c|c|c|c|}
\hline Estabelece limites & & Risco & Frequência & Não risco & Frequência \\
\hline \multirow[t]{16}{*}{$\begin{array}{l}\text { Antecedentes do } \\
\text { comportamento materno }\end{array}$} & \multirow[t]{6}{*}{$\begin{array}{l}\text { Razões- } \\
\text { Contexto }\end{array}$} & $\begin{array}{l}\text { Concepções de } \\
\text { certo e errado }\end{array}$ & 2 & Concepções de certo e errado & 6 \\
\hline & & $\begin{array}{l}\text { Controle do } \\
\text { comportamento }\end{array}$ & 7 & Controle do comportamento & 10 \\
\hline & & Responsabilidade & 2 & Responsabilidade & 6 \\
\hline & & & & Tudo há limites & 1 \\
\hline & & $\begin{array}{l}\text { Prevenção de } \\
\text { problemas }\end{array}$ & 1 & & \\
\hline & & Ensinar o certo & 2 & Ensinar o certo & 4 \\
\hline & \multirow{7}{*}{$\begin{array}{l}\text { Situações- } \\
\text { Contexto }\end{array}$} & Horários & 4 & Horários & 7 \\
\hline & & Televisão & 1 & Televisão & 3 \\
\hline & & Estudos & 5 & Estudos & 2 \\
\hline & & Computador & 4 & Computador & 3 \\
\hline & & Vídeo-game & 1 & & \\
\hline & & Saídas noturnas & 2 & & \\
\hline & & Alimentos & 1 & & \\
\hline & \multirow[t]{3}{*}{$\begin{array}{l}\text { Problemas } \\
\text { do filho }\end{array}$} & $\begin{array}{l}\text { Não arruma o } \\
\text { quarto }\end{array}$ & 1 & & \\
\hline & & Bagunça & 1 & & \\
\hline & & Barulho & 1 & & \\
\hline Sentimento materno & HSE-P & & & Sente-se bem & 3 \\
\hline \multirow[t]{9}{*}{ Comportamento materno } & \multirow[t]{3}{*}{ HSE-P } & Conversa & 9 & Conversa & 6 \\
\hline & & $\begin{array}{l}\text { Diz não com } \\
\text { explicação }\end{array}$ & 1 & Explica & 5 \\
\hline & & & & Pede mudança & 1 \\
\hline & \multirow{6}{*}{$\begin{array}{l}\text { Prática } \\
\text { negativa }\end{array}$} & Retira privilégios & 4 & Retira privilégios & 2 \\
\hline & & Grita & 4 & Ameaça retirar privilégios & 1 \\
\hline & & Ameaça & 3 & & \\
\hline & & Castigo & 1 & & \\
\hline & & Bate & 2 & & \\
\hline & & Xinga & 2 & & \\
\hline \multirow[t]{10}{*}{ Comportamento do filho } & \multirow{10}{*}{$\begin{array}{l}\text { Problemas } \\
\text { do filho }\end{array}$} & Fica triste & 1 & Fica triste & 1 \\
\hline & & Faz birras & 6 & & \\
\hline & & Fica brabo & 4 & & \\
\hline & & $\begin{array}{l}\text { Responde em } \\
\text { tom agressivo }\end{array}$ & 7 & & \\
\hline & & Fala palavrões & 1 & & \\
\hline & & Chora & 3 & Chora & 1 \\
\hline & & Não fala nada & 2 & & \\
\hline & & Desobedece & 1 & & \\
\hline & & $\begin{array}{l}\text { Faz as coisas } \\
\text { escondido }\end{array}$ & 1 & & \\
\hline & & Ignora & 3 & & \\
\hline
\end{tabular}

Os eventos descritos na Tabela 24 mostram que as mães do grupo de risco se atentam mais para os problemas de comportamento dos filhos, utilizam de maior frequência de práticas negativas como retirar privilégios, gritar, ameaçar, castigar, bater e xingar. Bem como 
os seus filhos apresentam maior frequência de problemas comportamentais como fazer birras, ficar brabo, responder em tom agressivo, falar palavrões, chorar, não falar nada, desobedecer, fazer coisas escondido e ignorar os limites dados pelas mães.

No grupo de não risco as mães dão mais importância para que o filho aprenda a distinguir o certo do errado, para tanto utilizam de práticas educativas positivas (HSE-P) como conversar, explicar o porquê do limite e pedir mudança de comportamento. Apesar de algumas mães deste grupo utilizarem a retiradas de privilégios e alguns filhos apresentarem comportamentos como ficar triste e chorar, isto ocorre em menor frequência.

Com relação à subcategoria identificar erros, a Figura 9 mostra os resultados encontrados.

\section{ESTABELECIMENTO DE LIMITES}
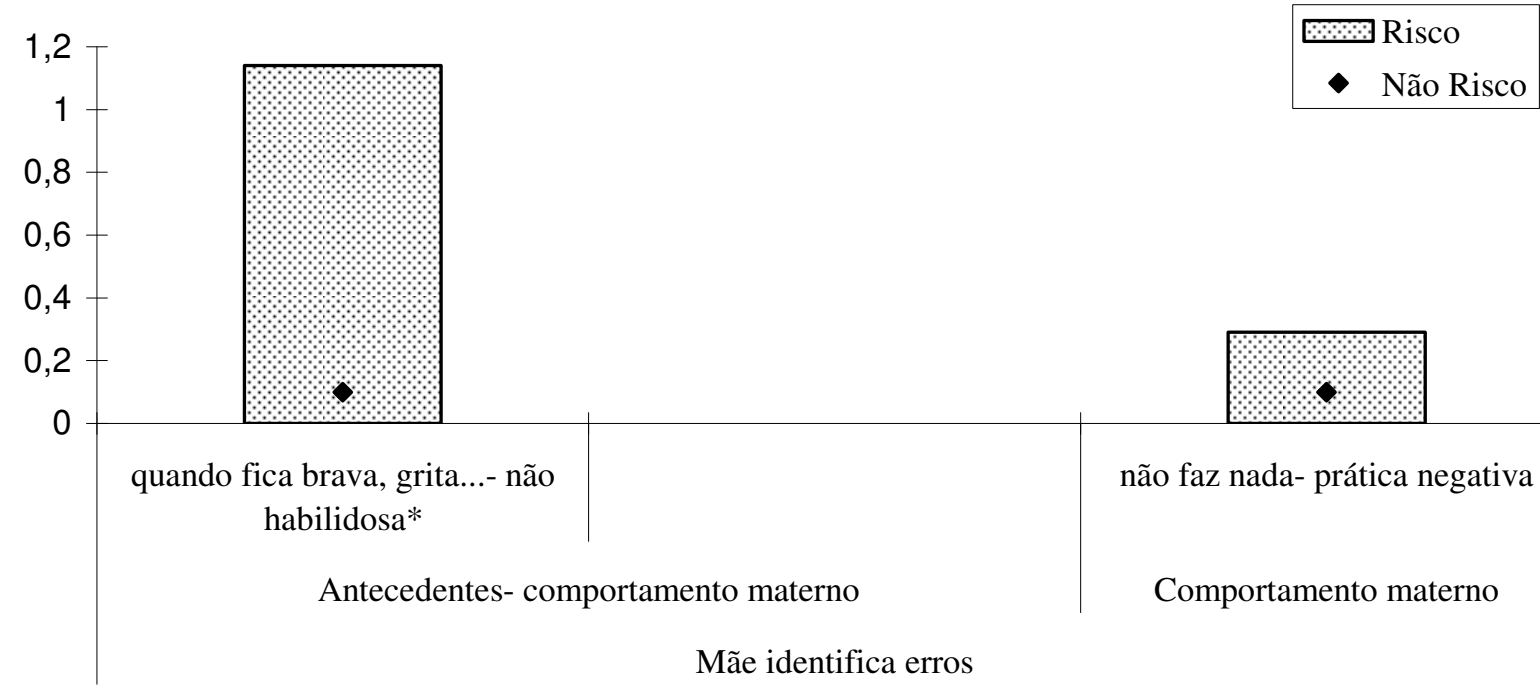

Mãe identifica erros

Figura 9 - Comparação entre amostra de risco e não risco sobre a frequência da subcategoria identificar erros, das Habilidades Sociais Educativas Parentais (HSE-P) de estabelecimento de limites. As diferenças estatísticas significantes estão representadas pelos asteriscos *.

Como mostra a Figura 9, a identificação de erros por parte das mães no que diz respeito à prática negativa ativa, na qual a mãe identifica que age ou agiu de forma inadequada quando fica brava, grita, discute, é mais frequente entre as mães do grupo de risco que as de não risco (média risco $=0,29$ / média não risco $=0,1$ e $\mathrm{p}=0,00$ ). Já a prática negativa passiva materna de identificar erros e não fazer nada, após a identificação de erros, foi pouco frequente em ambos os grupos, sem diferença estatística significativa (média risco = 0,29 /média não risco $=0,1$ e $\mathrm{p}=0,28$ ) 
Para análise mais detalhada dos comportamentos da subcategoria identificar erros foi elaborada a Tabela 25, contendo a descrição dos comportamentos emitidos pelas mães e filhos de ambos os grupos.

Tabela 25 - Descrição e frequência dos comportamentos apresentados pelas mães e filhos de ambos os grupos na subcategoria mãe identifica erros na educação do filho.

\begin{tabular}{|c|c|c|c|c|c|}
\hline Identifica erros & & Risco & Frequência & Não risco & Frequência \\
\hline \multirow{8}{*}{$\begin{array}{l}\text { Antecedentes do } \\
\text { comportamento } \\
\text { materno de } \\
\text { identificar os seus } \\
\text { erros na educação } \\
\text { do filho }\end{array}$} & \multirow{8}{*}{$\begin{array}{l}\text { Prática negativa } \\
\text { (Percebe que } \\
\text { errou quando...) }\end{array}$} & $\begin{array}{l}\text { Critica demais, pune } \\
\text { demais }\end{array}$ & 4 & \multirow[t]{8}{*}{ Quando fico brava } & \multirow[t]{8}{*}{1} \\
\hline & & Briga/ grita & 3 & & \\
\hline & & Xinga & 1 & & \\
\hline & & $\begin{array}{l}\text { Pede muitas coisas } \\
\text { para a filha }\end{array}$ & 1 & & \\
\hline & & $\begin{array}{l}\text { Não cumpre } \\
\text { promessas }\end{array}$ & 1 & & \\
\hline & & Bate & 2 & & \\
\hline & & Coloca de castigo & 1 & & \\
\hline & & Excesso de culpa & 1 & & \\
\hline \multirow{3}{*}{$\begin{array}{l}\text { Comportamento } \\
\text { materno }\end{array}$} & \multirow{3}{*}{$\begin{array}{l}\text { Prática negativa } \\
\text { (O que faz } \\
\text { quando percebe } \\
\text { que errou) }\end{array}$} & Briga & 1 & \multirow{3}{*}{ Não faz nada } & \multirow{3}{*}{1} \\
\hline & & Não faz nada & 2 & & \\
\hline & & $\begin{array}{l}\text { Fazer o que quer por } \\
\text { dó }\end{array}$ & 1 & & \\
\hline
\end{tabular}

A Tabela 25 mostra que as mães do grupo de risco de forma geral identificam mais erros em suas práticas educativas ao criticar demais, punir excessivamente, brigar, gritar, xingar, não cumprir promessas, bater, colocar de castigo e sentir excesso de culpa. Bem como essas mães ao detectarem tal prática, ao invés de repará-las, brigam mais com os filhos, não fazem nada ou fazem as vontades do filho por dó. Em oposição, o grupo de não risco quase não apresentou a identificação de práticas negativas na relação com os filhos.

Com relação à subcategoria faz coisas que a mãe gosta, a Figura 10 apresenta os resultados encontrados.

ESTABELECIMENTO DE LIMITES

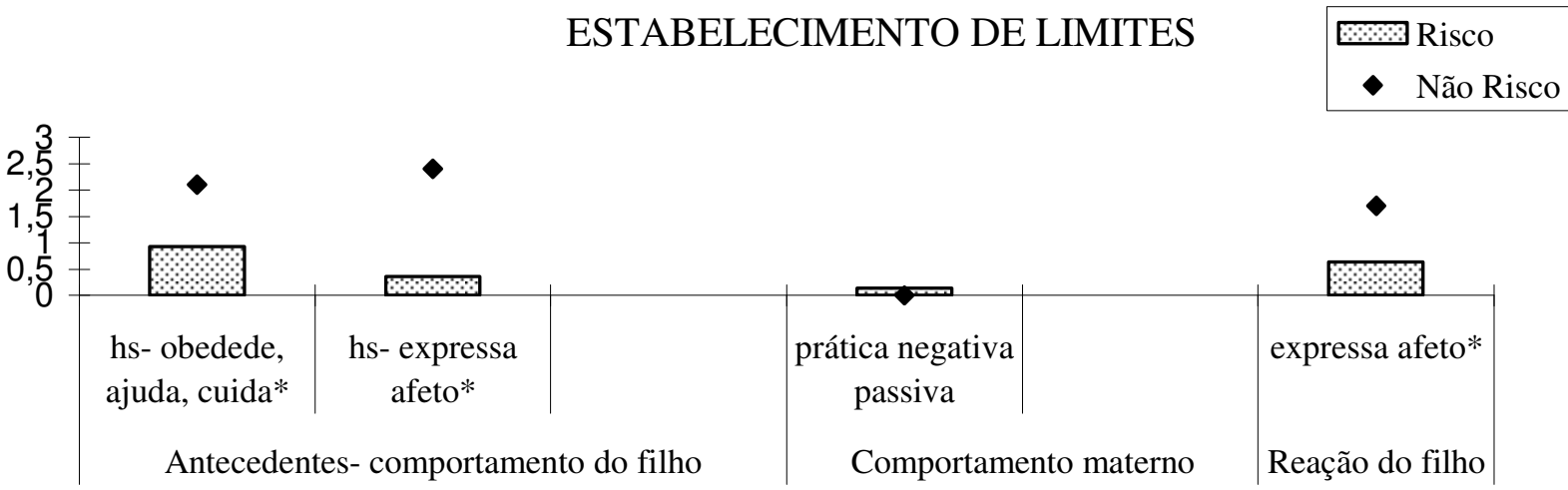

Filho faz coisas que a mãe gosta

Figura 10 - Comparação entre amostra de risco e não risco sobre a frequência da subcategoria faz coisas que a mãe gosta, das Habilidades Sociais Educativas Parentais (HSE-P) de estabelecimento de limites. As diferenças estatísticas significantes estão representadas pelos asteriscos *. 
Sobre fazer coisas que as mães gostam (Figura 10), os adolescentes do grupo de não risco mostram-se mais habilidosos obedecendo, ajudando, cooperando (média risco $=0,93$ / média não risco $=2,1$ e $\mathrm{p}=0,03$ ) e expressando afeto (média risco $=0,36$ / média não risco $=$ 2,4 e p=0,00), antes da emissão do comportamento materno. As mães de ambos os grupos apresentam pouca frequência de práticas negativas passivas neste tipo de interação (média risco $=0,14$ / média não risco $=0 \mathrm{e} \mathrm{p}=0,22)$. E a reação dos adolescentes do grupo de não risco após fazerem coisas que as mães gostam, novamente mostra-se mais habilidosa que no grupo de risco, com diferença estatística significativa (média risco $=0,64$ / média não risco $=$ $1,7$ e $\mathrm{p}=0,00)$.

Para análise mais detalhada dos comportamentos encontrados na subcategoria faz coisas que a mãe gosta foi elaborada a Tabela 26, contendo a descrição dos comportamentos emitidos pelas mães e filhos de ambos os grupos.

Tabela 26 - Descrição e frequência dos comportamentos apresentados pelas mães e filhos de ambos os grupos na subcategoria faz coisas que a mãe gosta.

\begin{tabular}{|c|c|c|c|c|c|}
\hline \multicolumn{2}{|c|}{ Filho faz coisas que a mãe gosta } & \multirow{2}{*}{$\begin{array}{l}\text { Risco } \\
\text { Amoroso }\end{array}$} & \multirow{2}{*}{$\frac{\text { Frequência }}{2}$} & \multirow{2}{*}{$\frac{\text { Não risco }}{\text { Amoroso }}$} & \multirow{2}{*}{$\frac{\text { Frequência }}{8}$} \\
\hline Comportamento do & HS do filho & & & & \\
\hline \multirow[t]{13}{*}{ filho } & (Afeto) & Carinhoso & 2 & Carinhoso & 2 \\
\hline & & Alegre & 1 & Alegre & 7 \\
\hline & & & & Responsável & 2 \\
\hline & & & & Empático & 3 \\
\hline & & & & Obediente & 1 \\
\hline & & & & Agrada a mãe & 2 \\
\hline & $\begin{array}{l}\text { HS do filho } \\
\text { (Disponibilidade) }\end{array}$ & $\begin{array}{l}\text { Procura ajudar- } \\
\text { limpar a casa, } \\
\text { cuidar dos } \\
\text { irmãos, do } \\
\text { cachorro }\end{array}$ & 8 & $\begin{array}{l}\text { Procura ajudar- } \\
\text { limpar a casa, } \\
\text { cuidar dos } \\
\text { irmãos, do } \\
\text { cachorro }\end{array}$ & 10 \\
\hline & & Estuda & 1 & Estuda & 4 \\
\hline & & Caprichosa & 1 & Obediente & 4 \\
\hline & & Cozinha & 3 & Educado & 4 \\
\hline & & & & Disposto & 1 \\
\hline & & & & Tem boas idéias & 1 \\
\hline & & & & Cuidadoso & 2 \\
\hline $\begin{array}{l}\text { Comportamento } \\
\text { materno }\end{array}$ & Prática negativa & Não faz nada & 2 & & \\
\hline \multirow{7}{*}{$\begin{array}{l}\text { Comportamento do } \\
\text { filho } \\
\text { (reação do filho) }\end{array}$} & HS do filho & Fica orgulhoso & 2 & Fica orgulhoso & 2 \\
\hline & & Sorri & 4 & Sorri & 7 \\
\hline & & Beija & 2 & Beija & 3 \\
\hline & & Abraça & 1 & Abraça & 2 \\
\hline & & $\begin{array}{l}\text { Chama a mãe } \\
\text { para comer o } \\
\text { que fez }\end{array}$ & 1 & $\begin{array}{l}\text { Diz que ama a } \\
\text { mãe }\end{array}$ & 1 \\
\hline & & & & $\begin{array}{l}\text { Diz coisas } \\
\text { legais para mae }\end{array}$ & 1 \\
\hline & & & & Agradece & 1 \\
\hline
\end{tabular}

Como pode ser visto na Tabela 26, os adolescentes do grupo de não risco apresentam maior frequência e variabilidade de comportamentos habilidosos afetivos tais como agir de 
forma amorosa, carinhosa, alegre, responsável, empática, obediente e agradável para com a mãe. Também apresentam maior frequência e diversidade de comportamentos de disponibilidade como procurar ajudar a limpar a casa, cuidar dos irmãos e do cachorro, estudar, obedecer, ter boas idéias, agir de forma cuidadosa e disponível.

Conseqüentemente ao comportamento do filho, somente duas mães do grupo de risco apresentaram a reação de não fazer nada após o filho ter feito coisas que ela gosta.

E a reação dos filhos perante o comportamento materno no grupo de não risco foi frequentemente positiva através de comportamentos como ficar orgulhoso, sorrir, beijar, abraçar, dizer que ama ou dizer coisas legais para a mãe e agradecer. No grupo de risco, os adolescentes também apresentaram reações habilidosas semelhantes, mas menos frequentes.

Sobre o fazer coisas que a mãe não gosta, a Figura 11 apresenta os resultados gerais encontrados.

ESTABELECIMENTO DE LIMITES

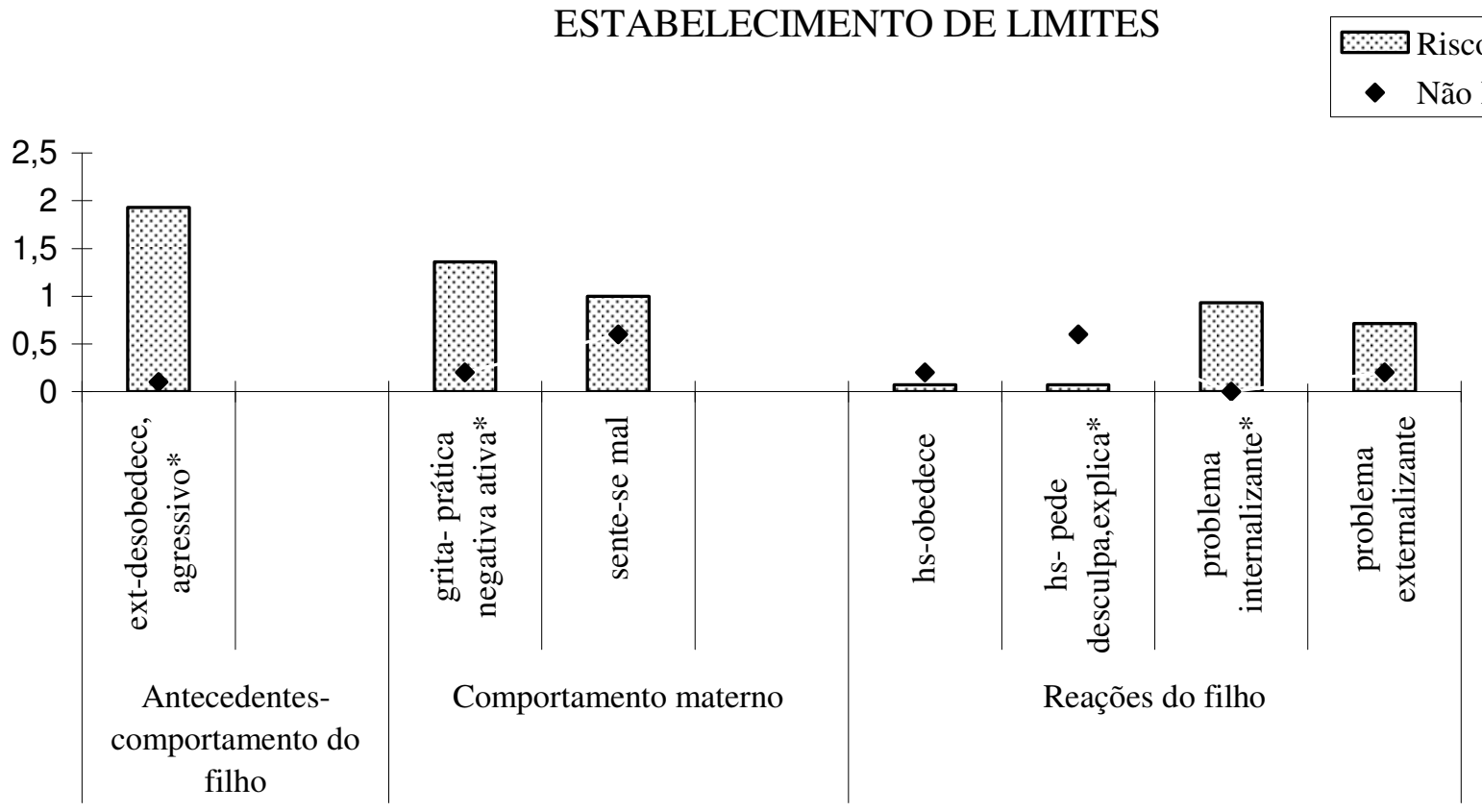

Filho faz coisas que a mãe não gosta

Figura 11 - Comparação entre amostra de risco e não risco sobre a frequência da subcategoria faz coisas que a mãe não gosta, das Habilidades Sociais Educativas Parentais (HSE-P) de estabelecimento de limites. As diferenças estatísticas significantes estão representadas pelos asteriscos *.

A subcategoria faz coisas que as mães não gostam apresenta diferenças estatísticas na comparação entre os grupos, conforme a Figura 11 mostra, apontando para presença mais frequente de práticas negativas maternas no grupo de risco, como gritar quando o filho faz algo que não gosta (média risco $=1,36 /$ média não risco $=0,2 \mathrm{e} p=0,00$ ). Houve maior incidência de problemas de comportamento externalizantes dos filhos do grupo de risco 
antecedentes do comportamento materno, como agressividade e desobediência (média risco = 1,93 / média não risco $=0,1$ e $\mathrm{p}=0,00$ ) e maior ocorrência de problemas internalizantes conseqüentes ao comportamento materno, como chorar e ficar triste, nos adolescentes do grupo de risco (média risco $=0,93 /$ média não risco $=0$ e p $=0,05$ ).

As mães de ambos os grupos se sentem mal quando os filhos fazem coisas que não gostam, sem diferença estatística entre os grupos (média risco $=1 /$ média não risco $=0,6$ e p $=$ 0,19). As reações dos filhos são mais habilidosas no sentido de pedir desculpas e explicar-se para as mães no grupo de não risco que no grupo de risco, com diferença estatística significativa (média risco $=0,07$ / média não risco $=0,6$ e p=0,04). A habilidade dos filhos de disponibilidade e cooperação é semelhante em ambos os grupos, sem diferença estatística significativa (média risco $=0,07 /$ média não risco $=0,2$ e $\mathrm{p}=0,35$ ). Quanto aos externalizantes, conseqüentes ao comportamento materno, como chorar, a ocorrência é semelhante em ambos os grupos, sem diferença estatística significativa (média risco $=0,7$ / média não risco $=0,2$ e p=0,11).

Os comportamentos específicos apresentados pelas mães e pelos filhos na subcategoria faz coisas que a mãe não gosta, estão apresentados na Tabela 27.

Tabela 27 - Descrição e frequência dos comportamentos apresentados pelas mães e filhos de ambos os grupos na subcategoria faz coisas que a mãe não gosta.

\begin{tabular}{|c|c|c|c|c|c|}
\hline \multicolumn{2}{|c|}{ Filho faz coisas que a mãe não gosta } & Risco & Frequência & Não risco & Frequência \\
\hline \multirow{12}{*}{$\begin{array}{l}\text { Antecedentes do } \\
\text { comportamento materno }\end{array}$} & \multirow{12}{*}{$\begin{array}{l}\text { Problemas do } \\
\text { filho }\end{array}$} & Briga & 3 & & \\
\hline & & Mente & 4 & & \\
\hline & & $\begin{array}{l}\text { Manipula, concorda } \\
\text { na frente, mas não } \\
\text { faz combinado }\end{array}$ & 1 & & \\
\hline & & Desobedece & 5 & & \\
\hline & & $\begin{array}{l}\text { Responde os mais } \\
\text { velhos }\end{array}$ & 1 & & \\
\hline & & Fuma & 2 & & \\
\hline & & Bebe & 2 & & \\
\hline & & Mata aulas & 2 & & \\
\hline & & Não estuda & 8 & & \\
\hline & & Reprovou & 1 & & \\
\hline & & $\begin{array}{l}\text { Deixa suas coisas } \\
\text { desorganizadas }\end{array}$ & 1 & & \\
\hline & & Faz xixi na cama & 1 & & \\
\hline \multirow[t]{8}{*}{ Comportamento materno } & \multirow{4}{*}{$\begin{array}{l}\text { Prática } \\
\text { negativa } \\
\text { (sentimento } \\
\text { materno) }\end{array}$} & Impotência & 1 & $\begin{array}{l}\text { Tristeza/ } \\
\text { desapontamento }\end{array}$ & 5 \\
\hline & & Raiva & 2 & & \\
\hline & & $\begin{array}{l}\text { Sente-se errada/ } \\
\text { culpada }\end{array}$ & 3 & & \\
\hline & & Passa mal & 1 & & \\
\hline & \multirow{4}{*}{$\begin{array}{l}\text { Prática } \\
\text { negativa ativa } \\
\text { (ação materna) }\end{array}$} & Ameaças & 1 & \multirow{4}{*}{ Briga } & \multirow{4}{*}{1} \\
\hline & & Briga & 9 & & \\
\hline & & Bate & 3 & & \\
\hline & & Grita & 1 & & \\
\hline
\end{tabular}




\begin{tabular}{|c|c|c|c|c|c|}
\hline & Xinga & 2 & \multirow{3}{*}{$\begin{array}{l}\text { Retira } \\
\text { privilégios }\end{array}$} & \multirow{3}{*}{1} \\
\hline & & Retira privilégios & 1 & & \\
\hline & & $\begin{array}{l}\text { Conversa, mas não } \\
\text { consegue colocar } \\
\text { limites }\end{array}$ & 1 & & \\
\hline \multirow[t]{16}{*}{$\begin{array}{l}\text { Comportamento dos filhos } \\
\text { (Reação dos filhos) }\end{array}$} & \multirow[t]{4}{*}{ HS dos filhos } & $\begin{array}{l}\text { Aceita, diz que vai } \\
\text { mudar }\end{array}$ & 1 & Aceita & 3 \\
\hline & & $\begin{array}{l}\text { Tenta explicar para a } \\
\text { mãe o porquê }\end{array}$ & 1 & $\begin{array}{l}\text { Tenta explicar } \\
\text { para a mãe o } \\
\text { porquê }\end{array}$ & 1 \\
\hline & & & & Pede desculpas & 2 \\
\hline & & & & $\begin{array}{l}\text { Fica } \\
\text { envergonhado }\end{array}$ & 2 \\
\hline & \multirow{4}{*}{$\begin{array}{l}\text { Problema de } \\
\text { comportamento } \\
\text { internalizante }\end{array}$} & Ignora & 1 & & \\
\hline & & Chora & 4 & & \\
\hline & & Fica quieto & 4 & Fica quieto & 1 \\
\hline & & $\begin{array}{l}\text { Concorda, } \\
\text { contrariado }\end{array}$ & 1 & & \\
\hline & \multirow{8}{*}{$\begin{array}{l}\text { Problema de } \\
\text { comportamento } \\
\text { externalizante }\end{array}$} & Enfrenta a mãe & 1 & \multirow[t]{8}{*}{$\begin{array}{l}\text { Às vezes, } \\
\text { persiste no erro }\end{array}$} & 1 \\
\hline & & Faz birras & 2 & & \\
\hline & & Mente & 4 & & \\
\hline & & Fica brabo & 1 & & \\
\hline & & $\begin{array}{l}\text { Responde de cara } \\
\text { feia }\end{array}$ & 2 & & \\
\hline & & Desobedece & 1 & & \\
\hline & & $\begin{array}{l}\text { Manipula, concorda } \\
\text { na frente, mas faz } \\
\text { tudo errado }\end{array}$ & 1 & & \\
\hline & & $\begin{array}{l}\text { Diz que não } \\
\text { consegue estudar }\end{array}$ & 1 & & \\
\hline
\end{tabular}

Os resultados apresentados na Tabela 27, referente ao fato do filho fazer coisas que a mãe não gosta, mostram que as mães do grupo de risco focam nos problemas de comportamento dos filhos tais como: brigar, mentir, manipular, desobedecer, responder de forma desrespeitosa os mais velhos, fumar, beber, não estudar, matar aulas, reprovar, deixar coisas desorganizadas, fazer xixi na cama. Tais problemas de comportamento dos filhos não foram detectados pelas mães do grupo de não risco.

As mães do grupo de risco, quando os filhos fazem coisas que elas não gostam, reagem utilizando práticas negativas ativas tais como ameaçar, brigar, bater, gritar, xingar, retirar privilégios e conversar sem colocar limites nos filhos. Já as mães do grupo de não risco, apesar de se sentirem mal, não fazem uso de práticas negativas ativas.

Os filhos do grupo de risco reagem a tais práticas negativas de forma problemática tanto de forma internalizante quanto externalizante. Através de comportamentos como ignorar, chorar, ficar quieto, concordar mesmo estando contrariado, enfrentar a mãe, fazer birras, mentir, ficar brabo, responder de cara feia, desobedecer, manipular e dizer que não 
consegue estudar. Os adolescentes do grupo de não risco apresentam mais habilidades sociais do que problemas de comportamento em situações nas quais fazem coisas que a mãe não gosta, tais como aceitar que fez algo que não foi legal, tentar explicar para a mãe o porquê do seu comportamento, ficar envergonhado e pedir desculpas.

A categoria entendimento conjugal envolve aspectos relacionados à concordância entre o casal sobre a educação do filho e sua influência sobre os mesmos, como apresentado na Figura 12:

ENTENDIMENTO CONJUGAL

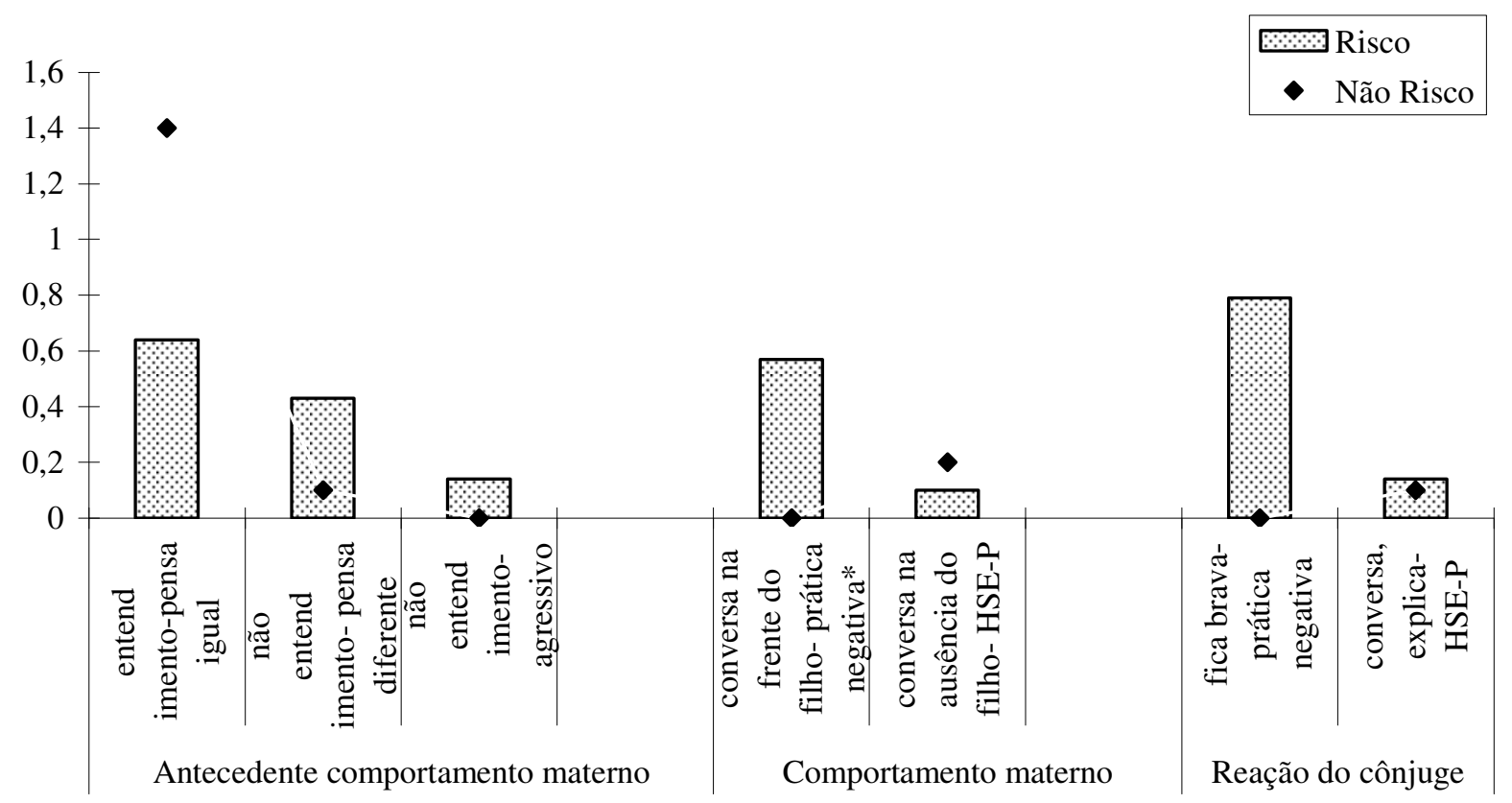

Figura 12 - Comparação entre amostra de risco e não risco sobre a frequência da HSEP entendimento conjugal. As diferenças estatísticas significantes estão representadas pelos asteriscos *.

Sobre o entendimento dos casais em relação à educação dos filhos (Figura 12), segundo o relato das mães, somente a prática negativa ativa conversar sobre dificuldades e brigar na frente do filho (prática negativa ativa) apresenta diferença entre os grupos. Sendo mais frequente entre as mães do grupo de risco falar com o cônjuge, na presença dos adolescentes, sobre comportamentos inadequados dos filhos (média risco $=0,79$ / média não risco $=0$ e $p=0,03)$, o que não houve entre as mães de não risco.

Os demais aspectos abordados foram semelhantes para ambos os grupos: o fato das mães e seus cônjuges terem pensamentos e crenças sobre educação similares (média risco = 0,64 / média não risco $=1,4$ e $\mathrm{p}=0,1$ ) foram mais frequentes em ambos os grupos do que pensar diferente sobre a forma de educar (média risco $=0,43 /$ média não risco $=0,1$ e $\mathrm{p}=$ 
0,15). O comportamento agressivo de um dos cônjuges foi nulo no grupo de não risco e pouco frequente no de risco (média risco $=0,14$ /média não risco $=0$ e $\mathrm{p}=0,22$ ).

A HSE-P conversar na ausência do filho foi pouco frequente em ambos os grupos (média risco $=0,14$ / média não risco $=0,1 \mathrm{e} \mathrm{p}=0,83$ ). A reação do casal após a conversa, HSE-P conversar e admitir erros, pedir desculpas para o cônjuge, não apresentou diferença significativa entre os grupos (média risco $=0,1 /$ média não risco $=0,2 \mathrm{e} \mathrm{p}=0,75$ ). $\mathrm{E}$ a reação não habilidosa das mães, de ficar brava após as conversas, também foi semelhante em ambos os grupos (média risco $=0,79 /$ média não risco $=0$ e $\mathrm{p}=0,07$ ), sem diferença estatística significativa.

Algumas dimensões do Roteiro de Entrevista de Habilidades Sociais Educativas Parentais (RE-HSE-P) são avaliadas para verificar as habilidades sociais educativas de forma mais abrangente pelo instrumento. As dimensões englobam expressão materna de sentimentos negativos, dificuldades das mães em cumprir promessas, concordância entre o casal, filhos fazem o que as mães não gostam e comportamento materno de fazer perguntas sobre sexualidade (Figura 13):

\section{HABILIDADES SOCIAIS EDUCATIVAS PARENTAIS- HSE-P}

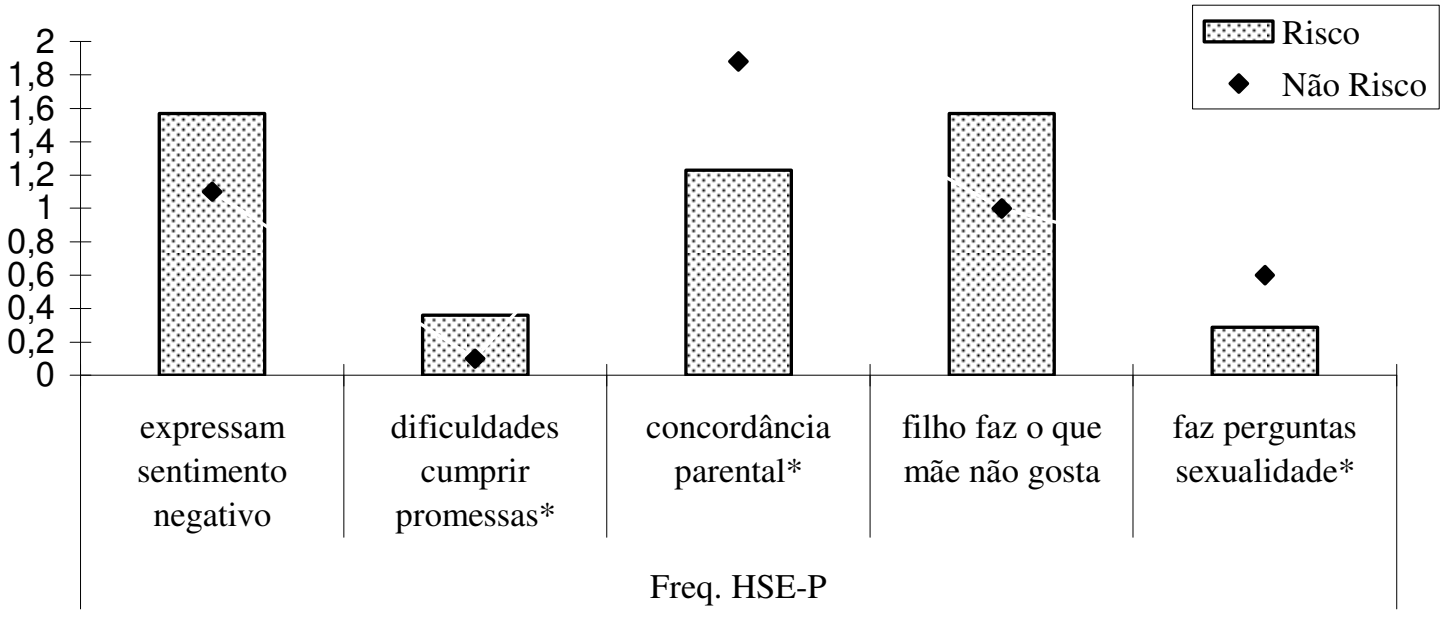

Figura 13 - Comparação entre amostra de risco e não risco sobre as dimensões do HSE-P. As diferenças estatísticas significantes estão representadas pelos asteriscos *.

A partir da Figura 13, pode-se notar que os grupos apresentam diferenças estatísticas significativas no que se refere à dificuldade de cumprir promessas, concordância parental e perguntas de sexualidade. A frequência da dificuldade em cumprir promessas foi maior para o grupo de risco (média risco $=0,36 /$ média não risco $=0,1$ e $p=0,00$ ), a concordância entre os 
pais teve maior incidência no grupo de não risco (média risco $=1,23$ / média não risco $=1,88$ e $\mathrm{p}=0,00$ ) e as mães do grupo de não risco fazem mais perguntas sobre sexualidade (média risco $=0,29$ / média não risco $=0,6$ e $\mathrm{p}=0,00$ ).

A expressão de sentimentos negativos, apesar de mais frequente no grupo de risco, não apresentou diferença estatística significativa na comparação entre os grupos (média risco = $1,57 /$ média não risco $=1,1, \mathrm{p}=0,055)$. Bem como as mães do grupo de risco consideram que seus filhos fazem mais coisas que elas não gostam que no grupo de não risco, mas sem diferença estatística significativa entre os grupos (média risco $=1,57$ / média não risco $=1 \mathrm{e}$ $\mathrm{p}=0,23)$.

A análise geral avaliada pelo Roteiro de Entrevista de Habilidades Sociais Educativas Parentais (RE-HSE-P) está apresentada na Figura 14:

ANÁLISE GERAL- RE-HSE-P

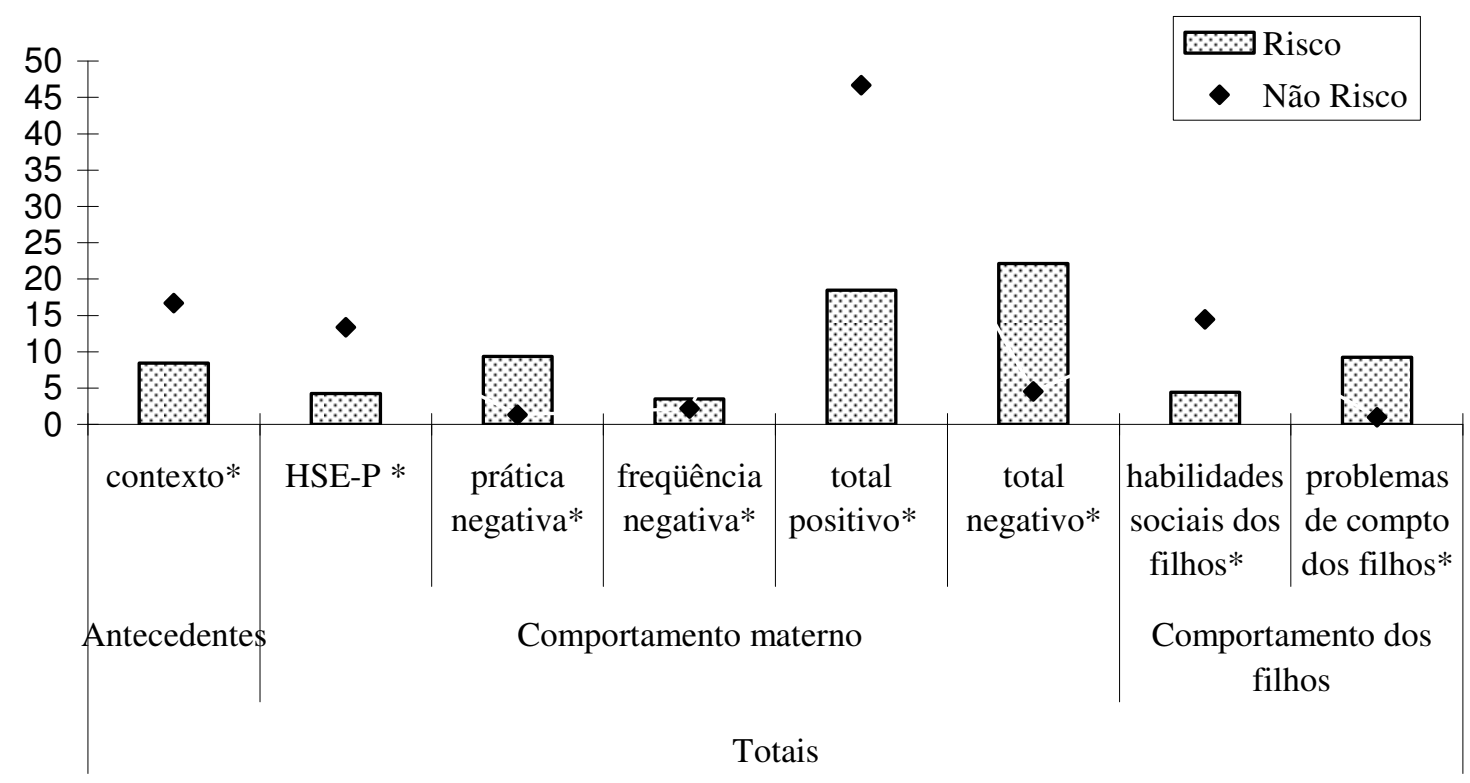

Figura 14- Análise geral do RE-HSE-P comparando os grupos de risco e não risco para problemas de comportamento do adolescente. As diferenças estatísticas significantes estão representadas pelos asteriscos *.

A análise geral mostra que as situações de contexto interativo entre mães e filhos de não risco são mais frequentes que entre as mães e filhos do grupo de risco (média risco = 8,43 / média não risco $=16,7$ e $\mathrm{p}=0,00$ ). As mães do grupo de não risco são mais habilidosas (HSE-P) nas relações com seus filhos que as do grupo de risco (média risco = 4,21/ média não risco $=13,4$ e $\mathrm{p}=0,00)$. As mães do grupo de risco apresentam mais práticas negativas que as de não risco (média risco $=9,36 /$ média não risco $=1,3$ e p $=0,00$ ). As mães do grupo de risco 
apresentam maior frequência de práticas negativas que as de não risco (média risco $=9,36$ / média não risco $=1,3$ e $\mathrm{p}=0,00)$. As mães do grupo de não risco apresentam maior frequência de total de práticas positivas (média risco $=18,5$ / média não risco $=46,7$ e $\mathrm{p}=$ 0,00 ) e as mães do grupo de risco maior frequência de total negativo (média risco $=22,14$ / média não risco $=4,5$ e $\mathrm{p}=0,00)$. Bem como os filhos do grupo de não risco são mais habilidosos que os de risco (média risco $=4,43$ / média não risco $=14,5$ e p $=0,00$ ), os quais apresentam maior frequência de problemas de comportamento (média risco = 9,29 / média não risco $=1$ e $\mathrm{p}=0,00)$.

Para a busca de correlações entre as variáveis do Roteiro de Entrevista de Habilidades Sociais Educativas Parentais (RE-HSE-P) aplicou-se o teste Spearman. Os resultados das correlações entre as variáveis do RE-HSE-P para o grupo de risco estão apresentados na Tabela 28:

Tabela 28 - Resultados da Correlação Spearman referente às classificações do RE-HSE-P do grupo de risco para problemas de comportamento do adolescente.

\begin{tabular}{|c|c|c|c|c|c|c|c|c|c|}
\hline Spearman & $\begin{array}{l}\text { HSE } \\
\text { das } \\
\text { mães }\end{array}$ & $\begin{array}{l}\text { Prática } \\
\text { negativa } \\
\text { materna }\end{array}$ & $\begin{array}{l}\text { HS dos } \\
\text { filhos }\end{array}$ & $\begin{array}{l}\text { Problemas } \\
\text { dos filhos }\end{array}$ & Contexto & $\begin{array}{l}\text { Freq. } \\
\text { prática } \\
\text { positiva } \\
\text { materna }\end{array}$ & $\begin{array}{l}\text { Freq. } \\
\text { prática } \\
\text { negativa } \\
\text { materna }\end{array}$ & $\begin{array}{l}\text { Total } \\
\text { positivo } \\
\text { materno }\end{array}$ & $\begin{array}{l}\text { Total } \\
\text { negativo } \\
\text { Materno }\end{array}$ \\
\hline $\begin{array}{l}\text { HSE das } \\
\text { mães }\end{array}$ & - &,$- 530 *$ & - & ,666* & - & - & - & - &, $544^{*}$ \\
\hline $\begin{array}{l}\text { Prática } \\
\text { negativa } \\
\text { materna }\end{array}$ &, $530 *$ & - &,$- 565^{*}$ & ,778* &,$- 477 *$ &,$- 515^{*}$ &, $742 *$ &,$- 583^{*}$ & ,927* \\
\hline $\begin{array}{l}\text { HS dos } \\
\text { filhos }\end{array}$ & - &,$- 565^{*}$ & - &,$- 505^{*}$ & ,738* & - & - &, $921 *$ &,$- 519 *$ \\
\hline $\begin{array}{l}\text { Problemas } \\
\text { dos filhos }\end{array}$ &, $666^{*}$ &, $778^{*}$ &,$- 505^{*}$ & - &,$- 441^{*}$ &,$- 456^{*}$ & ,675* &,$- 481 *$ & ,928* \\
\hline Contexto & - &,$- 477 *$ &, $738 *$ &,$- 441 *$ & - &, $514 *$ & - & ,908* &,$- 418 *$ \\
\hline $\begin{array}{l}\text { Freq. prática } \\
\text { positiva } \\
\text { materna }\end{array}$ & - &,$- 515^{*}$ & - &,$- 456^{*}$ &, $514 *$ & - &,$- 429 *$ & ,479* &,$- 513 *$ \\
\hline $\begin{array}{l}\text { Freq. prática } \\
\text { negativa } \\
\text { materna }\end{array}$ & - &, $742 *$ & - &, $675^{*}$ & - &,$- 429 *$ & - & - &, $803^{*}$ \\
\hline $\begin{array}{l}\text { Total } \\
\text { Positivo } \\
\text { materno }\end{array}$ & - &,$- 583^{*}$ & ,921* &,$- 481 *$ & ,908* & ,479* & - & - &,$- 504^{*}$ \\
\hline $\begin{array}{l}\text { Total } \\
\text { negativo } \\
\text { materno }\end{array}$ &, $544 *$ & ,927* &,$- 519 *$ & ,928* &,$- 418^{*}$ &,$- 513 *$ &, $803 *$ &,$- 504 *$ & - \\
\hline
\end{tabular}

Legenda: Os números com asterisco representam os valores que apontam para correlações, os demais itens não apresentaram correlações.

Como pode ser visto na Tabela 28, referente às correlações do grupo de risco, as Habilidades Sociais Educativas (HSE) maternas estão negativamente correlacionadas às práticas negativas maternas, aos problemas de comportamento do adolescente e ao total de práticas negativas maternas. As práticas negativas maternas também apresentam correlação 
negativa com Habilidades Sociais (HS) dos filhos, problemas de comportamento dos filhos, contexto, frequência de práticas positivas maternas, frequência de práticas negativas maternas, total de práticas positivas e total de práticas negativas maternas.

As habilidades sociais (HS) dos filhos estão negativamente correlacionadas aos problemas de comportamento dos mesmos, ao contexto, ao total de práticas positivas e ao total de práticas negativas maternas. Os problemas de comportamento dos filhos estão negativamente correlacionados ao contexto, a frequência de práticas positivas, a frequência de práticas negativas e ao total de práticas positivas e negativas maternas. O contexto, situações de interação entre mães e filhos, está negativamente correlacionado a frequência de práticas positivas, ao total de práticas positivas e ao total de práticas negativas maternas.

A frequência de práticas positivas maternas está negativamente correlacionada à frequência de práticas negativas, ao total de práticas positivas e ao total de negativas maternas. A frequência de práticas negativas maternas está negativamente correlacionada ao total de práticas negativas. $\mathrm{O}$ total de práticas positivas maternas está negativamente correlacionado ao total de práticas negativas.

As correlações entre as variáveis do Roteiro de Entrevista de Habilidades Sociais Educativas Parentais (RE-HSE-P) para o grupo de não risco também foram avaliadas através do teste Spearman. Esses resultados estão apresentados na Tabela 29:

Tabela 29 - Resultados da Correlação de Spearman referente às classificações do RE-HSE-P do grupo de não risco.

\begin{tabular}{|c|c|c|c|c|c|c|c|c|c|}
\hline Spearman & $\begin{array}{l}\text { HSE } \\
\text { das } \\
\text { mães }\end{array}$ & $\begin{array}{l}\text { Prática } \\
\text { negativa } \\
\text { materna }\end{array}$ & $\begin{array}{l}\text { HS dos } \\
\text { filhos }\end{array}$ & $\begin{array}{l}\text { Problemas } \\
\text { dos filhos }\end{array}$ & Contexto & $\begin{array}{l}\text { Freq. } \\
\text { prática } \\
\text { positiva } \\
\text { materna }\end{array}$ & $\begin{array}{l}\text { Freq. } \\
\text { prática } \\
\text { negativa } \\
\text { materna }\end{array}$ & $\begin{array}{l}\text { Total } \\
\text { positivo } \\
\text { materno }\end{array}$ & $\begin{array}{l}\text { Total } \\
\text { negativo } \\
\text { Materno }\end{array}$ \\
\hline $\begin{array}{l}\text { HSE das } \\
\text { mães }\end{array}$ & - & - & - & - & - &, $854 *$ & - & - & \\
\hline $\begin{array}{l}\text { Prática } \\
\text { negativa } \\
\text { materna }\end{array}$ & - & - & - & - & - & - & - & - &, $639 *$ \\
\hline $\begin{array}{l}\text { HS dos } \\
\text { filhos }\end{array}$ & - & - & - & - & - & - & - & - & \\
\hline $\begin{array}{l}\text { Problemas } \\
\text { dos filhos }\end{array}$ & - & - & - & - & - & - & - & - &, $639 *$ \\
\hline Contexto & & - & - & - & - & - & - &, $979 *$ & - \\
\hline $\begin{array}{l}\text { Freq. prática } \\
\text { positiva } \\
\text { materna }\end{array}$ &, $854 *$ & - & - & - & - & - & - & - & - \\
\hline $\begin{array}{l}\text { Freq. prática } \\
\text { negativa } \\
\text { materna }\end{array}$ & - & - & - & - & - & - & - & - &, $770 *$ \\
\hline $\begin{array}{l}\text { Total } \\
\text { Positivo } \\
\text { materno }\end{array}$ & - & - & - & - & ,979* & - & - & - & - \\
\hline $\begin{array}{l}\text { Total } \\
\text { negativo } \\
\text { materno }\end{array}$ & - &, $639 *$ & - &, $639 *$ & - & - &, $770 *$ & - & - \\
\hline
\end{tabular}


Legenda: Os números com asterisco representam os valores que apontam para correlações, os demais itens não apresentaram correlações.

Através da Tabela 29, sobre as correlações do RE-HSE-P do grupo de não risco, notase que as habilidades sociais educativas maternas (HSE) apresentam correlação negativa com frequência de práticas positivas maternas. As práticas negativas maternas estão correlacionadas negativamente com o total de práticas negativas maternas. Os problemas de comportamento dos filhos estão correlacionados negativamente com o total de práticas negativas maternas. $\mathrm{O}$ contexto está correlacionado negativamente com o total de práticas positivas maternas. A frequência de práticas positivas maternas está correlacionada negativamente com as HSE maternas. A frequência de práticas negativas maternas está correlacionada negativamente com as HSE e com o total de práticas negativas maternas. $\mathrm{O}$ total de práticas negativas maternas está correlacionado negativamente aos problemas de comportamento dos filhos.

Os resultados obtidos pela aplicação do Child Behavior Check-List (CBCL) estão apresentados abordando as médias, os escores, as classificações diagnósticas e a apresentação geral das classificações diagnósticas do CBCL.

As médias para problemas de comportamentos infanto-juvenis, nos participantes do grupo de risco e não risco, podem ser vistas na Tabela 30:

Tabela 30 - Médias e aplicação do teste Mann-Whitney para comparação dos resultados do grupo de não risco e não risco para classificação diagnóstica do CBCL.

\begin{tabular}{|c|c|c|c|}
\hline CBCL & Grupo risco & Grupo não risco & Valor \\
\hline & Médias (desvio padrão) & Médias (desvio padrão) & $\mathrm{P}$ \\
\hline $\begin{array}{l}\text { Problemas } \\
\text { internalizantes }\end{array}$ & $64(8,75)$ & $55,9(6,91)$ & 0,043 \\
\hline $\begin{array}{l}\text { Problemas } \\
\text { externalizantes }\end{array}$ & $65,5(8,37)$ & $46,3(9,88)$ & 0,000 \\
\hline $\begin{array}{l}\text { Escore de distúrbio } \\
\text { total }\end{array}$ & $67,57(5,04)$ & $53,8(7,39)$ & 0,000 \\
\hline
\end{tabular}

Com relação à análise do instrumento CBCL (Tabela 30) que avalia os problemas de comportamento inter e externalizantes dos adolescentes, os grupos apresentam diferenças estatísticas significantes em todos os aspectos avaliados. A frequência dos problemas de comportamento inter e externalizantes são maiores para os adolescentes do grupo de risco, destacando que a diferença entre os grupos é maior para os problemas externalizantes $(\mathrm{p}=0,00)$. Bem como o escore total de distúrbios de comportamento é maior para os adolescentes do grupo de risco. 
Os resultados das classificações diagnósticas obtidos pela aplicação do CBCL estão apresentados detalhadamente na Tabela 31, a qual apresenta o escore e a classificação de cada participante da pesquisa com relação aos problemas de comportamento:

Tabela 31 - Escores e classificação em população clínica, borderline e não clínico do CBCL em população de risco e não risco para problemas de comportamento do adolescente.

\begin{tabular}{lllll}
\hline Grupos & Participantes & Internalizantes & Externalizantes & Total \\
\hline RISCO & 1 & 57 & $71-\mathrm{c}$ & $73-\mathrm{c}$ \\
& 2 & 56 & $71-\mathrm{c}$ & $68-\mathrm{c}$ \\
& 3 & $73-\mathrm{c}$ & $66-\mathrm{c}$ & $71-\mathrm{c}$ \\
& 4 & $67-\mathrm{c}$ & $66-\mathrm{c}$ & $70-\mathrm{c}$ \\
& 5 & $77-\mathrm{c}$ & $66-\mathrm{c}$ & $72-\mathrm{c}$ \\
& 6 & $71-\mathrm{c}$ & $60-\mathrm{b}$ & $66-\mathrm{c}$ \\
& 7 & $68-\mathrm{c}$ & $83-\mathrm{c}$ & $75-\mathrm{c}$ \\
& 8 & 52 & $63-\mathrm{b}$ & $63-\mathrm{b}$ \\
& 9 & 58 & 59 & 58 \\
& 10 & $71-\mathrm{c}$ & $61-\mathrm{b}$ & $67-\mathrm{c}$ \\
& 11 & $60-\mathrm{b}$ & $64-\mathrm{c}$ & $68-\mathrm{c}$ \\
& 12 & 48 & $68-\mathrm{c}$ & $62-\mathrm{b}$ \\
& 13 & $67-\mathrm{c}$ & 46 & $61-\mathrm{b}$ \\
$\mathrm{NÃO}$ RISCO & $71-\mathrm{c}$ & $73-\mathrm{c}$ & $49-\mathrm{c}$ \\
& 14 & 58 & 40 & 58 \\
& 15 & $62-\mathrm{b}$ & 53 & 54 \\
& 16 & 53 & 46 & 45 \\
& 17 & 44 & 34 & $64-\mathrm{c}$ \\
\hline 18 & $66-\mathrm{c}$ & 56 & 48 \\
& 19 & 48 & 44 & $64-\mathrm{c}$ \\
& 20 & 59 & $66-\mathrm{c}$ & $61-\mathrm{b}$ \\
& 21 & $61-\mathrm{b}$ & 46 & 47 \\
\hline 2 & 50 & 44 & 34 & \\
\hline
\end{tabular}

Legenda: a letra $\mathrm{b}$ indica borderline e a letra c clínico

Nota-se pela Tabela 31 que os adolescentes da amostra de risco 1, 2, 3, 4, 5, 6, 7, 10, 11 e 14 apresentam escore total indicativo de amostra clínica, isto é, com indícios de problemas de comportamentos presentes em amostras clínicas da população. Os adolescentes 8,12 e 13 estão classificados como borderline, isto é, na faixa de risco para desenvolvimento de problemas de comportamento. O único participante do grupo de risco que não apresenta indicativos de problemas de comportamento do grupo de risco é o nono.

Dentre os adolescentes da amostra de não risco, somente o $19^{\circ}$. e o $21^{\circ}$. apresentam escores indicativos de amostra clínica, o $22^{\circ}$. tem escore indicativo de borderline e os demais não apresentam indicativos de problemas de comportamento segundo o CBCL. Para facilitar o entendimento, a Tabela 32 expõe de forma geral o número de participantes da amostra de risco e não risco com indicativos de problemas clínicos, borderline e sem indicativos de problemas comportamentais. 
Tabela 32 - Frequência de participantes com problemas clínicos, borderline e não clínicos para amostra de risco e não risco.

\begin{tabular}{lll}
\hline CBCL & Grupo de risco & Grupo de não risco \\
\hline Problemas internalizantes & $\begin{array}{l}8 \text { clínicos/ } 1 \text { borderline/ } 5 \text { não } \\
\text { clínicos } \\
9 \text { clínicos/ } 3 \text { clínico/ } 2 \text { borderline/ } 2 \text { não } \\
\text { clínico } \\
1 \text { clínico/ } 9 \text { não clínicos }\end{array}$ \\
Problemas Externalizantes & $\begin{array}{l}\text { clínicos } \\
10 \text { clínicos/ } 3 \text { borderline/ } 1 \text { não } \\
\text { clínico }\end{array}$ & $\begin{array}{l}2 \text { clínicos/ } 1 \text { borderline/ } 7 \text { não } \\
\text { clínicos }\end{array}$ \\
\hline
\end{tabular}

No que diz respeito aos problemas de comportamento internalizantes (Tabela 32), a amostra de risco apresenta oito casos clínicos, um borderline e 5 normais. A amostra de não risco apresenta um caso clínico, dois borderline e sete não clínicos. Sobre problemas de comportamentos externalizantes, a amostra de risco tem nove casos clínicos, três borderline e dois não clínicos. Dos participantes de não risco, somente um caso clínico externalizante e os demais não clínicos. Sobre o panorama geral da frequência de problemas de comportamento segundo o CBCL, a população de risco é composta por 10 casos clínicos, 3 borderline e 1 não clínico, enquanto que na amostra de não risco há somente 2 casos clínicos, 1 borderline e 7 não clínicos. Pode-se notar a maior incidência de casos clínicos e borderline na amostra de risco. 


\section{DISCUSSÃO}

Esta seção apresenta a discussão dos resultados referentes às análises funcionais das interações entre mães e filhos adolescentes dos grupos de risco e de não risco, na qual são avaliadas as práticas educativas maternas, as habilidades sociais educativas maternas e os comportamentos dos adolescentes. Mais especificamente, discutem-se os resultados referentes aos dados do Inventário de Estilo Parental Materno - IEP -, as análises globais do Roteiro de Entrevista de Habilidades Sociais Educativas Parentais - RE-HSE-P -, as análises qualitativas do RE-HSE-P, as análises gerais do RE-HSE-P e os dados do Child Behavior Checklist CBCL.

\subsection{ANÁLISES DAS PRÁTICAS EDUCATIVAS MATERNAS}

Em relação à análise das práticas maternas, segundo o IEP (GOMIDE, 2006), o grupo de não risco apresentou maior incidência de todas as práticas positivas (monitoria positiva e comportamento moral) e menor incidência de todas as práticas negativas (punição inconsistente, disciplina relaxada, monitoria negativa, negligência e abuso físico). Os adolescentes relataram que suas mães utilizam mais práticas positivas do que negativas, motivo pelo qual estas práticas ocorreram com pouca frequência no grupo de não risco.

Os adolescentes do grupo de não risco perceberam suas mães mais próximas. Elas aplicavam regras consistentes e contingentes ao mesmo tempo em que demonstravam carinho, afeto e compreensão. Um fator relevante da monitoria positiva, diz respeito à comunicação entre pais e filhos pautada numa relação mais calorosa e menos punitiva (GOMIDE, 2003, 2004, 2006; STANTTIN, KERR, 2000).

Os aspectos da monitoria positiva são apontados por diversos estudos como primordiais na aprendizagem das habilidades sociais do adolescente (GOMIDE, 2003, 2004, 2006). São essenciais também na prevenção de problemas de comportamento (BORAWSKI et al., 2003; FLETCHER; STEINBERG; WILLIAMS-WHEELER, 2004; DICLEMENTE et al., 2001; DISHION; MCMAHON, 1998; FLETCHER et al., 2004; GOMIDE, 2004, 2006; STATTIN; KERR, 2000). É o que indica também o estudo de Pettit et al. (2001) ao mostrar que os altos níveis de monitoria materna estão associados à baixa frequência de comportamentos delinquentes dos filhos adolescentes. A ausência da monitoria materna, 
porém, para os diferentes autores, está relacionada a maiores níveis de delinquência em adolescentes.

Borawski et al. (2004) também apresentaram resultados que confirmam a influência da monitoria na prevenção de problemas de comportamento ao afirmarem que os adolescentes sob efeito de monitoria parental são menos propensos ao envolvimento sexual sem proteção. Os resultados da pesquisa de Fletcher, Steinberg e Williams-Wheeler (2004) mostraram que os adolescentes são menos propensos ao uso de substâncias quando seus pais são calorosos e envolvidos em suas vidas, quando procuram obter informações sobre as suas atividades e quando se proveem de níveis equilibrados de controle sobre tais atividades. Todos esses aspectos são característicos da monitoria positiva.

O comportamento moral materno teve maior incidência entre o grupo de não risco do que entre o de risco. Destaca-se que o comportamento moral é complementar à monitoria positiva por envolver aspectos de respeito para com o filho e com as pessoas em geral. É complementar também por envolver valores como honestidade, igualdade, generosidade que são estimuladores das habilidades sociais do filho, em especial a empatia que possibilita ao jovem aprender a se colocar no lugar do outro. Tal prática educativa também envolve a análise do próprio comportamento e a reparação de danos (GOMIDE, 2003; 2004; 2006).

Entre os adolescentes do grupo de risco, a percepção sobre as práticas educativas maternas foi negativa. Eles apontaram que suas mães utilizavam, com maior frequência, práticas coercitivas como punição inconsistente, disciplina relaxada, monitoria negativa, negligência e abuso físico.

A punição inconsistente materna, frequentemente relatada pelo grupo de risco, transmite ao adolescente a dificuldade para discriminar quais comportamentos são adequados e quais não. Isso acontece porque as ações maternas de punir os comportamentos do filho de acordo com o estado emocional do momento nem sempre são contingentes aos comportamentos emitidos pelo adolescente (GOMIDE, 2003, 2004).

A alta incidência de punição inconsistente também foi verificada nos resultados das correlações do grupo de risco. Os resultados mostraram que os altos níveis desse tipo de punição estavam associados aos índices de estilo materno negativos que caracterizam a predominância de práticas coercitivas nesse grupo. Dentre as consequências advindas de tal prática negativa, podem surgir alguns problemas de comportamento nos filhos, como manipulação, mentiras e omissão de informações por parte dos adolescentes (GOMIDE, 2004). 
A disciplina relaxada, que esteve presente com maior frequência entre as práticas maternas aplicadas aos adolescentes do grupo de risco, traz consigo a inconsistência das práticas educativas. Quando as mães estipulam consequências após os comportamentos inadequados dos filhos e não as aplicam, a regra passa a não ser cumprida. As consequências dessa prática são muito semelhantes às da punição inconsistente, pois os filhos aprendem a discriminar o que as mães falam, mas nem sempre cumprem com os acordos estipulados. Isso faz com que os mesmos comportamentos sejam acionados no repertório dos adolescentes, tais como falar e não cumprir, mentir, omitir e manipular (GOMIDE, 2004).

A monitoria negativa, presente com maior frequência entre as práticas maternas aplicadas aos adolescentes do grupo de risco, consiste em comportamentos de físcalização e controle materno que nem sempre visam o bem-estar do filho. Por exemplo, quando a mãe exige que ele ajude a arrumar a casa, mas ela grita para fazer o pedido ou reclama com hostilidade quando vê que o serviço não foi benfeito.

As práticas excessivamente punitivas, além de criarem um ambiente desagradável, podem dificultar os comportamentos independentes dos filhos e prejudicar a tomada de decisão do jovem. Consequentemente, essas práticas estão relacionadas à percepção da competência e autoestima do adolescente (LUYCKX et al., 2007; SOENENS et al., 2005; REICHERT; WAGNER, 2007; PACHECO; TEIXEIRA; GOMES, 2008).

Segundo Baumrind (1966), ao fazer uso do estilo parental autoritário, que apresenta características semelhantes à prática parental de monitoria negativa, os pais conduzem a educação dos filhos de acordo com suas expectativas. Eles desconsideram muitas vezes as necessidades e o ponto de vista do jovem, o que prejudica sua autonomia. Por exemplo, a mãe exige do filho a organização da casa conforme o seu nível de exigência, mas isso não é alcançado, o que a deixa frustrada. Nessas circunstâncias, ela utiliza a monitoria negativa como forma de controle do filho que, paradoxalmente à visão da mãe, passa a reagir agressivamente.

A monitoria negativa cria um ciclo vicioso. Quanto mais a mãe briga com o jovem, chama sua atenção e o fiscaliza, mais ele reage de forma opositora. Esse é o ciclo comportamental abordado por Sidman (2001), que discorre sobre o processo da coerção, e por Ross (1979), que fala sobre o efeito paradoxal que o controle aversivo exerce sobre os filhos. Consequentemente, quando os filhos rejeitam o que os pais ensinam, perdem a oportunidade para aprender novas habilidades sociais.

A negligência e o abuso físico foram muito frequentes no grupo de risco. A alta incidência de negligência também foi evidenciada a partir das correlações realizadas, o que 
mostrou uma associação entre os índices de estilo materno negativos e os altos níveis de negligência. Importante lembrar que as consequências da negligência e do abuso físico são extremamente prejudiciais ao desenvolvimento da autoestima e das habilidades sociais do jovem (GOMIDE, 2003, 2004).

A negligência pode transmitir ao filho a sensação de não ser amado, de não ser importante, o que fica evidente quando a mãe não reforça os comportamentos do filho. Um ambiente assim tem como característica o excesso de punição negativa, o que transforma a relação entre mães e filhos, pois ocorre uma retirada dos reforçadores contingentes. A indiferença transmitida pela negligência é prejudicial ao desenvolvimento do adolescente, já que não reforça os comportamentos positivos emitidos pelo filho, o que consequentemente prejudica a promoção de autoestima do mesmo. A negligência está associada, por isso, a problemas de comportamento, como a agressividade e a depressão (GOMIDE, 2004).

O abuso físico pode estimular o filho a manifestar tanto comportamentos agressivos quanto passivos, já que as ações violentas não estimulam o repertório de habilidades sociais do adolescente e não transmitem afeto. Segundo Sidman (2001), as ações parentais coercitivas podem gerar o mesmo tipo de reação; portanto, para o autor, coerção gera coerção.

As correlações obtidas com o IEP no grupo de mães de não risco apontaram para uma coerência maior das práticas utilizadas, como, por exemplo, quando as mães utilizaram o comportamento moral, não aplicaram a monitoria negativa nem a disciplina relaxada com seus filhos. Evidenciou-se também uma maior estabilidade no comportamento materno do grupo de não risco que, apesar de ter utilizado algumas práticas negativas, o fez com pouca frequência e apresentou a predominância das práticas educativas positivas, estimuladoras do repertório habilidoso dos filhos.

\subsection{ANÁLISES FUNCIONAIS DAS INTERAÇÕES ENTRE MÃES E ADOLESCENTES}

Em relação ao RE-HSE-P, as análises globais apontaram diferenças ao se comparar as HSE-P do grupo de risco e não risco para quase todas as categorias previstas pelo instrumento: habilidades sociais educativas maternas - HSEP -, situações de contexto para interação, práticas negativas maternas, frequência de práticas negativas, total de práticas positivas, total de práticas negativas, habilidades sociais dos filhos - HS - e problemas de 
comportamento dos jovens. Só não houve diferença estatística significativa na variável frequência de práticas positivas.

Os resultados permitem dizer que as mães do grupo de não risco relataram a emissão frequente de habilidades sociais educativas, interação maior com seus filhos (contexto) e uso menor de práticas negativas. Os resultados foram coerentes com os da literatura da área (BOLSONI-SILVA, 2003; BOLSONI-SILVA; DEL PRETTE, 2002) e concordantes com os resultados obtidos na aplicação do IEP nesta pesquisa. Isso significa que a percepção dos adolescentes sobre as práticas educativas maternas foi confirmada pelas mães ao responderem o RE-HSE-P.

Os estudos (BOLSONI-SILVA, 2003, 2008, 2009; GOMIDE et al., 2005; CIA; PEREIRA; DEL PRETTE; DEL PRETTE, 2006), em geral, apontam para as habilidades sociais dos pais e das mães como estimulantes do repertório de habilidades sociais dos filhos Nesta pesquisa, pôde ser observado que as mães do grupo de não risco apresentaram maior frequência de HSE-P e seus filhos apresentaram maior frequência de habilidades sociais e menor incidência de problemas de comportamento. Constatou-se também a influência das habilidades sociais educativas maternas sobre as habilidades sociais dos adolescentes e viceversa, o que pode ser visto nos dados relativos à análise qualitativa do RE-HSE-P que mostram as relações funcionais dos comportamentos maternos e filiais.

O contrário aconteceu no grupo de risco em que as mães utilizaram mais práticas negativas em detrimento das habilidades sociais educativas - HSE-P. Elas também interagiram menos com seus filhos (contexto). Em consequência, os filhos apresentaram mais problemas de comportamento e menos habilidades sociais.

Dito de outra forma, os filhos do grupo de risco reagiram às práticas negativas maternas de forma problemática, e as mães, na tentativa de controle, foram agressivas, gritaram, brigaram e xingaram. Em outros momentos, os filhos apresentaram problemas de comportamento antes da intervenção materna, como não estudar e matar aula, e as mães, na tentativa de modificar o comportamento deles, acabaram aplicando práticas negativas. Essas práticas mantiveram os problemas dos filhos, como foi constatado pelos dados gerais do REHSE-P e confirmado pelo CBCL.

Estudos reiteram a associação entre as práticas parentais negativas nas famílias em situação de risco e os problemas de comportamento. No trabalho desenvolvido por Pinheiro (2003), que investigou as práticas educativas em famílias de risco e de não risco, confirmouse a prevalência de práticas negativas, como, por exemplo, a monitoria negativa, o abuso físico e a negligência nos grupos familiares de risco. 
Patterson, Reid e Dishion (1992) detectaram que as práticas coercitivas são frequentes na população com altas taxas de criminalidade. Tais ações são determinantes na formação de problemas de comportamento, pois os filhos reagem coercitivamente ao padrão de comportamento parental aversivo. Essa situação familiar é denominada pelos autores de processo familiar coercitivo.

Em consonância com os estudos apresentados e com os resultados desta pesquisa, a proposta de Bolsoni-Silva $(2003,2008,2009)$ aponta para a influência mútua nas classes de respostas dos pais e filhos. Os comportamentos dos filhos, portanto, são contingentes às ações dos pais e vice-versa.

Em relação às avaliações qualitativas do RE-HSE-P, a análise da categoria de comunicação mostrou que as mães da amostra de não risco apresentaram mais habilidades sociais de conversa nas mais diversas situações e maior variabilidade de temas e assuntos. Quanto à conversação sobre o que é certo ou errado, ambos os grupos apresentaram alta frequência, o que é considerado habilidoso por parte das mães. O resultado reitera o fato de que as mães do grupo de não risco apresentaram mais habilidades sociais educativas e mais situações contextuais interativas. Tal processo criou oportunidades para uma relação mais próxima entre mães e filhos e estimulou as habilidades sociais dos adolescentes, porque as mães do grupo de não risco conversaram de forma mais adequada e frequente com seus filhos do que as mães do grupo de risco. Aquelas não apenas conversaram para estabelecer limites, mas também para tratar de assuntos do interesse dos filhos. Consequentemente, o processo aumentou as interações sociais positivas (contexto) e a aproximação entre eles.

As mães do grupo de não risco mostraram-se mais interessadas em conversar sobre assuntos diversos, como amizades, escola, futuro profissional, entre outros temas. Os filhos desse grupo apresentaram reações hábeis, como conversar demonstrando interesse, e não apresentaram problemas de comportamento diante dessas situações. Evidentemente as mães do grupo de não risco vivenciaram mais situações de interação positiva com seus filhos (contexto), o que possibilitou a estimulação de habilidades sociais e a prevenção de problemas nos adolescentes. Conversar sobre o que é certo ou errado é importante, mas, muito mais do que isso, esse comportamento deve servir para conhecer a vida do filho e para mostrar o interesse da mãe por ele.

Tais resultados vão ao encontro do estudo de Cia, Pamplin e Del Prette (2006) que, ao avaliar as habilidades sociais educativas parentais, mostrou que os filhos, cujos pais mantêm alta frequência de comunicação positiva, apresentavam um repertório maior de habilidades sociais. Autores da análise do comportamento enfatizam a importância dessas contingências 
reforçadoras positivas (BOLSONI-SILVA, 2003; SIDMAN, 2001; GOMIDE, 2003, 2004, 2006), já que elas previnem problemas de comportamento. A comunicação assertiva, realizada por meio da audição não punitiva e da expressão de opiniões aos filhos, é recomendável porque promove o envolvimento entre mães e filhos. É o que foi observado neste estudo, pois os adolescentes do grupo de não risco não apresentaram problemas de comportamento nas interações com conversa.

Ao contrário do que ocorreu com as mães do grupo de não risco, as do grupo de risco não conversaram com frequência sobre temas gerais com os jovens e o fizeram mais frequentemente diante de seus problemas externalizantes. Dessa falta de diálogo assertivo resultaram as mentiras, as notas baixas ou a irritação dos filhos, de modo que essa ação materna é caracterizada como uma prática negativa.

As mães do grupo de risco provavelmente deram mais atenção aos problemas de comportamento dos filhos, o que pode reforçar e promover a manutenção dos mesmos, já que os adolescentes da amostra apresentaram maior frequência de problemas de comportamento nas interações com conversa. Entre os problemas estão a agressividade verbal dos filhos e o fato destes não demonstrarem interesse quando a mãe fala ou mesmo quando ela não fala. $O$ resultado permite afirmar que as práticas negativas reforçam os problemas de comportamento dos jovens. No entanto, também foi observado que as mães do grupo de risco conversaram com seus filhos para ensinar o que é certo e errado, o que é uma boa estratégia se ela não for coercitiva, pois facilita a compreensão e a obediência do filho.

Destaca-se que, apesar dos adolescentes do grupo de não risco não terem apresentado diferenças referentes às habilidades sociais de conversação, na comparação com os adolescentes do grupo de risco, estes apresentaram problemas de comportamento na interação com conversa. Isso quer dizer que os adolescentes de risco tiveram habilidades sociais de comunicação na conversação com suas mães, mas sob a mesma contingência emitiram comportamentos problemáticos externalizantes ou internalizantes. Um resultado semelhante foi encontrado por Bolsoni-Silva (2009) quando investigou a relação entre mães e filhos na pré-escola e no ensino fundamental, o que parece estar de acordo também com a perspectiva desenvolvimentista de Patterson, Reid e Dishion (1992; 2002) sobre o processo familiar coercitivo.

Pode-se concluir que as interações com conversação do grupo de risco foram mais aversivas do que as do grupo de não risco. O resultado é coerente com o da literatura sobre o ciclo da coerção e o surgimento e a manutenção dos problemas de comportamento (PATTERSON; REID; DISHION, 1992; SIDMAN, 2001; GOMIDE, 2003; DISHION; 
MACMAHON, 1998). Ao darem mais atenção aos comportamentos inadequados dos filhos, os pais tornam a relação aversiva, o que reforça tais comportamentos que, em consequência, retroagem sobre toda família.

Tanto no ato de conversar como no de fazer perguntas, os resultados encontrados são semelhantes. Os assuntos pelos quais as mães fizeram perguntas foram frequentes e diversificados em ambos os grupos, o que é considerado uma habilidade social educativa materna. As mães do grupo de risco, no entanto, centraram suas perguntas nos problemas de comportamento dos filhos. Elas perguntaram sobre drogas, cigarro, maconha, sexo e sobre as obrigações escolares, o que não ocorreu entre as mães do grupo de não risco.

Os adolescentes do grupo de risco mostraram-se não habilidosos e apresentaram problemas de comportamento por não responder às perguntas maternas ou respondê-las de forma problemática: de forma agressiva, gritando; ou de forma lacônica, com respostas que interrompem a comunicação, falando que está tudo bem e saindo de perto das mães. Pode-se inferir que as práticas negativas maternas do grupo de risco influenciam as reações não habilidosas dos adolescentes; consequentemente, as mães reforçaram os problemas dos filhos com o uso de práticas negativas.

O contrário ocorreu no grupo de não risco em que as habilidades sociais dos adolescentes foram mais frequentes e não houve problemas de comportamento. Os adolescentes desse grupo incentivaram as mães a fazer perguntas, já que elas agiram com bom humor e falaram de novos assuntos. Elas também incentivaram seus filhos ao perguntar sobre seus temas de interesse.

Em consonância com a análise em questão, Stantin e Kerr (2000) afirmam que os pais que estimulam a troca de idéias e a conversação não necessitam de estratégias coercitivas para adquirir conhecimento a respeito da vida do filho. Ele aprende a falar espontaneamente de si quando se relaciona com seus pais. Os resultados deste estudo confirmam essa tese, porque as mães do grupo de não risco não relataram dificuldades ao conversar e fazer perguntas aos filhos. O contrário aconteceu no grupo de risco, no qual as mães detectaram que seus filhos agiam de forma não habilidosa, gritavam ou não respondiam com interesse.

Os resultados indicam que a qualidade da interação relacionada ao ato de perguntar, envolvendo tanto os comportamentos maternos quanto os filiais, foi melhor no grupo de não risco do que no de risco. As mães do grupo de risco, porém, apresentaram reservas comportamentais para a comunicação, isto é, elas sabiam fazer perguntas sobre a vida do filho, mas o faziam pautadas nos problemas deles. 
O déficit de habilidades de comunicação, apresentado pelas mães do grupo de risco nas interações com perguntas, pode ter sido prejudicial às habilidades sociais dos filhos e ter estimulado problemas de comportamento nos mesmos. Esse resultado é coerente com o da investigação sobre a habilidade social educativa de comunicação realizada por Bolsoni-Silva (2003). Ela observou que as mães de crianças com indicadores de competência social faziam mais perguntas para tentar ensinar as regras de convívio social do que as que tinham filhos com indicadores de problemas de comportamento. As mães destes jovens preocupavam-se em checar se eles tinham reclamações escolares. Em outro estudo, Bolsoni-Silva (2008) apontou ainda que as mães de crianças com problemas de comportamentos externalizantes no ensino fundamental apresentaram dificuldades para ouvir e responder às perguntas dos filhos, o que descaracteriza a comunicação assertiva e deixa transparecer a falta de interesse pelo filho.

Sidman (2001) adverte os pais que costumam conversar com seus filhos somente em situações de crítica ou quando impõem alguma restrição. Agindo assim, aqueles estão alimentando o ambiente coercitivo que ocasiona a restrição do repertório comportamental e mantêm os problemas de comportamento dos filhos. Patterson, Reid e Dishion (1992) perceberam que há uma tendência à manutenção de trocas irritáveis entre os membros nas famílias de risco. Ross (1979) alertou os pais para os efeitos paradoxais da punição severa que, ao invés de eliminar os problemas de comportamento dos filhos, pode incentivá-los e até mesmo mantê-los. Esses efeitos foram verificados na relação entre mães e filhos do grupo de risco.

Quanto à habilidade das mães e dos filhos para fazer perguntas sobre a sexualidade, subcategoria da comunicação, a frequência de perguntas referentes a esse tipo de assunto por parte das mães foi mínima em ambos os grupos. Isso pode ser justificado pela dificuldade que a sociedade, em geral, tem para lidar com o tema. Segundo Silvares (2002), conversar com os filhos sobre sexualidade não é fácil, afinal o tema exige que os pais tenham clareza sobre o assunto.

Dias e Gomes (1999) afirmam que tanto os pais quanto os filhos podem apresentar dificuldades para conversar sobre sexualidade. Os adolescentes podem sentir constrangimento e receio de que seus pais os desaprovem, e os pais podem se sentir despreparados para falar sobre o assunto. Falar sobre sexo exige destes não apenas a transmissão de informações, mas também a habilidade para estabelecer um diálogo nem autoritário nem permissivo (DIAS; GOMES, 2002).

Apesar das mães de ambos os grupos perguntarem pouco sobre assuntos de ordem sexual, os adolescentes do grupo de não risco mostraram-se mais habilidosos para conversar 
sobre esses temas. Eles fizeram mais perguntas para suas mães e conversaram mais sobre sexualidade do que os adolescentes do grupo de risco. Isso tem uma explicação, afinal tanto as mães quanto os adolescentes do grupo de não risco apresentaram maiores habilidades de comunicação em geral.

A partir dessa constatação, pode ter ocorrido a generalização da conversação para o tema sexualidade, pois mães e filhos do grupo de não risco já vinham conversando mais sobre diferentes assuntos ou porque as interações não eram estritamente punitivas, como aconteceu com o grupo de risco. Neste caso, grande parte das mães conversaram com os jovens sobre problemas de comportamento externalizantes e menos sobre outros assuntos que não remetiam a problemas. Portanto, para ambos os grupos conversar sobre sexualidade foi difícil, mas o foi, com mais frequência, para o grupo de risco.

Para Bolsoni-Silva (2003), quando os filhos procuram pelas mães para tirar dúvidas suas sobre sexualidade estão dando um indicativo de aproximação. Eles estão possibilitando que as mães os orientem sobre o assunto. Se os filhos mostrarem espontaneidade nessa interação com os pais, tem-se ainda o indicativo da qualidade da relação. Quando os adolescentes são espontâneos, estão demonstrando que confiam nos pais. Agindo assim, aqueles permitiram que estes adquirissem maior conhecimento sobre suas vidas e permitiram que estes lhes fornecessem orientação e direcionamento (FLETCHER; STEINBERG; WILLIAMS-WHEELER, 2004; STANTTIN; KERR, 2000).

A análise da expressão de sentimentos e o enfrentamento, que apresenta a expressão de sentimentos negativos e positivos, de opiniões e carinho, mostrou, de modo geral, que as mães do grupo de não risco e seus filhos agiram de forma mais habilidosa nesse tipo de interação, ou seja, elas conversaram com eles sobre situações e sentimentos desagradáveis, agradáveis, opinaram e expressaram mais carinho de forma habilidosa. Os estudiosos consideram essas habilidades para resolver conflitos em família como estimuladora das habilidades sociais dos filhos (PATTERSON; REID; DISHION, 1992; SILVEIRA et al., 2005). As mães quando expressam esses sentimentos negativos de forma assertiva estimulam a aprendizagem das habilidades sociais de seus filhos, em especial a habilidade para resolver problemas (DEL PRETTE; DEL PRETTE, 1999).

Um resultado positivo para os grupos, de risco e de não risco, foi que as mães não costumavam expressar sentimentos negativos por causa de problemas pessoais delas. Elas também não o faziam nos diversos momentos do dia e muito menos os expressavam após dar broncas nos filhos. Isso significa que as mães de ambos os grupos souberam controlar suas emoções e identificar o momento mais adequado para expressá-las. 
Estudiosos afirmam que é importante os pais discriminarem seus sentimentos e seus problemas pessoais para que não punam os filhos com base no humor não contingente ao comportamento do filho (GOMIDE, 2003, 2004; BOLSONI-SILVA, 2003, 2009). No caso desta pesquisa em específico, as mães de ambos os grupos foram habilidosas por não punirem seus filhos em demasia, nem várias vezes ao dia ou após as broncas. Parece que elas percebiam que o excesso de contingências punitivas é prejudicial aos filhos.

As mães da amostra de risco, porém, apresentavam práticas negativas com mais frequência e intensidade. Para elas, essas práticas foram identificadas como uma maneira de expressar tais sentimentos negativos. As mães disseram que costumavam gritar e ameaçar seus filhos, além de humilhá-los.

O resultado desta pesquisa se assemelha ao do estudo de Bolsoni-Silva (2003). A autora investigou pais e mães de pré-escolares com indicadores de problemas comportamentais e descobriu que eles utilizavam práticas negativas e, com menos frequência, usavam as habilidades sociais educativas na expressão dos sentimentos negativos. Para Patterson, Reid e Dishion (1992) resmungar, gritar, ameaçar e repreender o filho por problemas cotidianos é considerado uma prática parental ineficiente, porque não deixa alternativa ao comportamento do filho. Em outras palavras, as práticas negativas não incentivam os saltos comportamentais (ROSALES-RUIZ, 1997).

Mesmo sob a influência da alta frequência de práticas negativas e de poucas habilidades sociais educativas maternas na expressão de sentimentos negativos, os adolescentes do grupo de risco apresentaram reações semelhantes às do grupo de não risco. Escutar e obedecer à mãe, por exemplo. Isso indica que os filhos do grupo de risco apresentaram reservas comportamentais, isto é, habilidades sociais com pouca frequência, mas que podem ser aprimoradas com intervenções nessa população.

A expressão de sentimentos positivos esteve mais presente no grupo de não risco do que no de risco em todos os aspectos avaliados. As mães do grupo de não risco comunicaramse mais com seus filhos por meio da fala, da conversa; prestaram atenção neles e os elogiaram. Agindo assim, elas agradavam e faziam carinho em seus filhos, o que acontecia com mais frequência nesse grupo do que no de risco. O mesmo resultado foi encontrado também por Bolsoni-Silva (2003) ao investigar a relação entre mães e filhos pré-escolares sem indicadores de problemas de comportamento. Modelar positivamente o comportamento dos filhos com elogios e incentivos recebe o apoio da literatura e é primordial para a autoconfiança e a autoestima dos filhos (DISHION, MCMAHON, 1998; GUILHARDI, 2002). 
$\mathrm{Na}$ expressão de opiniões, tanto as mães quanto os filhos da amostra de não risco interagiram mais e apresentaram maior frequência de habilidades sociais em todos os aspectos avaliados. A expressão de opiniões em situações diversas (contexto) foi mais frequente entre as mães de não risco do que entre as de risco. Também as reações dos filhos de não risco foram frequentemente mais habilidosas. $\mathrm{O}$ resultado é coerente com o da literatura que explica o comportamento habilidoso dos filhos como influenciado pelo modelo de comportamento ofertado pelos pais (BOLSONI-SILVA; MARTURANO, 2002; GOMIDE, 2004) e pela habilidade deles para modelar o comportamento, no momento em que vão expressar suas opiniões para os filhos, utilizando o reforçamento positivo (BOLSONI-SILVA, 2003; DISHION; MCMAHON, 1998).

As consequências da interação pautada nos aspectos positivos podem afetar a percepção que o adolescente tem de si e dos pais (DISHION; MCMAHON, 1998). Para que o jovem se sinta bem consigo mesmo e com seus pais, é importante que a relação seja pautada na admiração e na valorização do filho, o que influencia a habilidade deste em relação à percepção de sua própria capacidade de agir (PLUNKETT et al., 2007). É por essa razão que se pode afirmar que o envolvimento materno e paterno positivo está associado ao estímulo da autonomia do jovem (LUYCKX et al., 2007; SOENENS et al., 2005; REICHERT; WAGNER, 2007; PACHECO; TEIXEIRA; GOMES, 2008).

Ao ser incentivado, o adolescente torna-se mais autoconfiante para tomar suas decisões e arcar com as consequências de seus atos. Ele sabe que vai receber apoio e também que há alternativas para que consiga resolver seus problemas (PACHECO; SILVEIRA; SCHNEIDER, 2008). As mães do grupo de não risco, ao estimularem seus filhos na expressão de suas opiniões, possivelmente incentivaram a autonomia dos adolescentes. Em consequência, estes se mostraram mais habilidosos na expressão de seus pensamentos e opiniões.

As mães e os filhos do grupo de risco apresentaram menor frequência de habilidades sociais na expressão de opiniões, e os adolescentes tiveram problemas internalizantes em sua interação. Como ações comuns nessa relação, os adolescentes ativeram-se a ouvir a opinião da mãe sem dizer nada ou a não gostar do que ouviam. Um dado interessante é o de que as habilidades dessas mães e seus filhos foram semelhantes às dos integrantes do grupo de não risco, mas menos frequentes. Pode-se dizer que, tanto em relação aos filhos quanto em relação às mães do grupo de risco, houve reservas comportamentais que podem ser estimuladas com intervenções voltadas para esse público. 
As dificuldades apresentadas pelo grupo de risco na expressão de opiniões podem ser explicadas pelo déficit de habilidades sociais maternas (DEL PRETTE; DEL PRETTE, 2005) e pela predominância de contingências aversivas nas interações familiares (PATTERSON; REID; DISHION, 1992; BOLSONI-SILVA, 2003; GOMIDE, 2004). Possivelmente as mães reforçam as opiniões dos filhos com pouca frequência e até mesmo intensidade. Em função disso, os filhos vão deixando de opinar e passam a se sentir menosprezados. Outra reação possível é a de que os adolescentes venham a punir as opiniões das mães da mesma forma que elas fizeram ou fazem com eles: não prestando atenção à opinião materna (punição negativa) e/ou demonstrando estar irritado (punição positiva). Esses exemplos estão em conformidade com o que foi observado nos adolescentes do grupo de risco.

Em relação à expressão de carinho, tanto os adolescentes quanto as mães de não risco agiram de forma mais carinhosa e, por isso, mais habilidosa nesse quesito. De modo geral, as mães de não risco agiram de maneira habilidosa tanto verbal quanto não verbal. Elas disseram que amavam, abraçavam e beijavam seus filhos com maior frequência do que as do grupo de risco. Assim também os adolescentes do grupo de não risco apresentaram maior disponibilidade e cooperação - HS - do que os do grupo de risco na expressão de carinho. Agindo assim, os adolescentes do grupo de não risco evidenciaram a provável aprendizagem da expressão de afeto na sua relação com as mães. É importante destacar, porém, que nenhum dos grupos de adolescentes apresentou problemas de comportamento nessas situações, o que é coerente com o que dizem as informações obtidas pela literatura (GOMIDE, 2004; OTTA, 1994) de que o afeto é inibidor de problemas comportamentais.

Os dados encontrados nesta pesquisa são consistentes e coerentes com os achados de Bolsoni-Silva (2003). As mães das crianças com indicadores de competência social demonstraram carinho com maior frequência e por meio das mais variadas formas (beijando, abraçando e fazendo carinho). Isso pode ser confirmado ao se comparar esse grupo com o das mães cujos filhos apresentaram indicadores de problemas comportamentais e por quem estas expressaram afeto predominantemente por meio da fala. Aqui ressalta novamente a importância da aprendizagem social na relação entre mães e filhos (BOLSONI-SILVA; MARTURANO, 2002; GOMIDE, 2003, 2004, 2006). As mães do grupo de não risco ensinaram os jovens a agir de forma mais carinhosa e disponível do que aquelas do grupo de risco; consequentemente, os filhos deste grupo raramente se mostraram disponíveis e expressaram carinho.

Em relação à subcategoria estabelecer limites, as mães do grupo de não risco estipularam mais limites para ensinar a distinção entre o certo e o errado, os aplicaram de 
forma mais habilidosa - HSEP - e se sentiram bem ao aplicá-los aos filhos. Ao contrário do grupo de risco, cujas mães apresentaram com mais frequência práticas negativas passivas e ativas ao estabelecerem limites aos filhos. Também os filhos deste grupo apresentaram maior incidência de problemas de comportamento nesse tipo de interação. As mães do grupo de risco apresentaram ainda dificuldades na aplicação de regras a seus filhos, o que provavelmente acarretou a não aceitação das normas, seja de forma aberta seja encoberta, por parte dos filhos.

O resultado apresentado é coerente com o da pesquisa de Bolsoni-Silva (2003). O uso da negociação por parte das mães cujos filhos dão indicativos de competência social predominou sobre as práticas coercitivas. As mães de crianças com indicativos de problemas de comportamento utilizaram tanto as práticas coercitivas quanto as de negociação com frequência similar, o que também pôde ser observado nas mães do grupo de risco deste estudo. Estas mães apresentaram frequência similar de práticas negativas e de HSE-P, o que indica a presença de reservas comportamentais nesse quesito. Em outras palavras, as mães sabem negociar e conversar, mas ao mesmo tempo aplicam práticas negativas que acabam prejudicando o estabelecimento de limites. Nesse sentido, as mães precisam de orientação para que possam identificar suas habilidades e as consequências do uso de práticas negativas, já que nem sempre estas e aquelas são discriminadas.

É importante destacar que há diferenças entre os grupos desde o motivo à aplicação dos limites, que são os antecedentes do comportamento materno, até a forma com que as mães se comportam quando precisam efetivar esses limites. As mães do grupo de risco com pouca frequência discriminaram a razão das regras e, apesar de tentarem aplicá-las, na maior parte das vezes de forma coercitiva, elas mesmas relataram que seus filhos continuavam apresentando os problemas de comportamento que elas gostariam de eliminar.

Parece que a falta de discriminação do que é essencial ou não para a educação dos filhos, por parte das mães do grupo de risco, prejudicou a aplicação de suas práticas educativas. Dishion e McMahon (1998) apoiam, por isso, a ideia de que a motivação das ações parentais são objetivos educativos que, quando não são discriminados pelos pais, podem prejudicar os adolescentes, pois ocasionam uma educação sem direcionamento, sem a clareza do que é importante para o convívio e a sobrevivência do filho em seu ambiente social.

Como mostram os resultados deste estudo, pode-se dizer que a falta de clareza das mães do grupo de risco para estabelecer limites prejudicou as habilidades sociais dos adolescentes. Há, pelo visto, um consenso da literatura sobre a importância do 
estabelecimento de limites e regras para o desenvolvimento das habilidades sociais dos filhos e da prevenção de problemas comportamentais (PATTERSON; REID; DISHION, 1992; DISHION; MCMAHON, 1998; BOLSONI-SILVA, 2003; GOMIDE, 2003). Os pais com dificuldade para educar consistentemente tendem a criar um ambiente que possibilita os problemas de comportamento (PATTERSON; REID; DISHION, 1992; GOMIDE, 1998; DISHION; MCMAHON, 1998).

Loos, Ferreira e Vasconcelos (1999) apontam para o papel fundamental dos pais de apresentar consequências coerentes aos atos transgressores dos filhos. Tal ação possibilita o desenvolvimento de sentimentos de culpa após as transgressões, de modo que eles indicam o desenvolvimento do comportamento moral necessário para o convívio pró-social. Provavelmente foi isso que não ocorreu no grupo de risco, tendo em vista que as mães se utilizaram de práticas estritamente coercitivas para a modificação do comportamento dos filhos. Estes, no entanto, continuavam agindo de forma inadequada, ou seja, gritando, xingando ou ignorando as recomendações maternas. Os filhos do grupo de risco provavelmente não estavam aprendendo a discriminar os comportamentos adequados dos inadequados, pois, como recebiam as orientações de forma agressiva, eles as rejeitavam com atitudes agressivas, consideradas problemáticas.

$\mathrm{Na}$ identificação dos erros relacionados às práticas educativas, subcategoria de estabelecimento de limites, as mães do grupo de risco perceberam que com frequência utilizavam práticas negativas. Entre elas encontra-se ficar brava, discutir, gritar, xingar e criticar demais o filho. O contrário ocorreu entre as mães de não risco que quase não identificaram erros em suas ações educativas. Tal resultado pode estar relacionado à dificuldade das mães de risco para estabelecer limites. Elas podem também não saber como lidar com situações inesperadas. Isso gera frustração e, ao mesmo tempo, provoca reações agressivas verbais e/ou gestuais por parte delas. Webster-Straton e Herbert (1994) afirmam que a irritabilidade materna pode gerar ou perpetuar os problemas de comportamento dos filhos com uma atenção negativa. Dessa forma, as mães acabam reforçando os comportamentos inadequados e a inconstante imposição dos limites.

Quanto à variável não fazer nada, após identificar os erros nas práticas educativas, as mães de ambos os grupos relataram não fazer nada com pouca frequência, o que é considerado prática negativa passiva. No entanto, as mães do grupo de não risco não fizeram nada, mas também com pouca frequência identificaram os erros, como gritar e ficar brava. Já as mães do grupo de risco não fizeram nada mesmo identificando que haviam errado na 
relação com os filhos. Nesse caso, pode-se afirmar que, apesar dos grupos terem apresentado frequências semelhantes nesse quesito, os resultados são distintos em cada um deles.

O fato das mães do grupo de risco discriminarem o erro e não tentarem reparar o dano, pode ser prejudicial à relação com os filhos e também ao desenvolvimento das habilidades sociais dos adolescentes, em especial a empática (FALCONE, 2000; GOMIDE; 2003, 2004). Como os filhos aprendem observando o modelo de comportamento das mães (GOMIDE, 2003, 2004; BOLSONI-SILVA; MARTURANO, 2002), esse tipo de comportamento não reparador materno pode ser aprendido pelos filhos e aplicado em suas interações sociais. Para os estudiosos das interações sociais, a habilidade de reparação dos erros é essencial para o bom convívio social e para prevenir comportamentos antissociais (DEL PRETTE; DEL PRETTE, 1999, 2001; GOMIDE, 2003, 2004, 2006).

Sobre fazer coisas que as mães gostam, isto é, sobre a categoria de estabelecimento de limites, os adolescentes do grupo de não risco mostraram-se mais habilidosos por meio da alta frequência de ações, como obedecer, ajudar, cooperar e expressar afeto. As mães desse grupo identificaram que seus filhos se comportavam assim antes delas intervirem e continuam agindo habilidosamente depois de suas intervenções.

Quanto aos comportamentos maternos, ambos os grupos quase não apresentaram práticas negativas passivas quando os filhos fizeram coisas que elas gostavam. Isso é extremamente positivo para todos, tendo em vista que a prática negativa poderia punir as habilidades sociais dos filhos. As reações dos adolescentes de não risco, porém, novamente foram mais habilidosas, já que expressaram o afeto com maior frequência após terem feito coisas que as mães gostam.

A habilidade para fazer as coisas que as mães gostam, ajudar e cooperar com elas são consideradas habilidades empáticas. Pais empáticos modelam o comportamento empático do filho, tendem a ser mais receptivos e a reforçar as respostas empáticas dele (FALCONE, 2000). Com base nessa informação, pode-se apreender que, para os filhos que estão inseridos em ambientes familiares, nos quais são estimulados a conversar, a expressar opiniões, a receber afeto e a expressar sentimentos positivos, é provável que seja mais fácil desenvolver a empatia em relação às suas mães e, consequentemente, saber agir para agradá-las. Esse processo foi observado no grupo de não risco.

Em relação ao adolescente, quando fizeram coisas que as mães não gostam, subcategoria de estabelecimento de limites, as mães do grupo de risco identificaram mais frequentemente problemas de comportamento externalizantes nos filhos antes de suas ações. Elas também relataram utilizar práticas negativas ativas nesse tipo de situação com maior 
frequência. As mães de ambos os grupos, por sua vez, sentiram-se mal quando os filhos fizeram coisas que elas não gostam. São sentimentos naturais frente às situações não esperadas e indesejadas. No entanto, as mães de não risco utilizaram as práticas negativas ativas nesse tipo de interação com pouca frequência, ao contrário das mães do grupo de risco que brigaram, ameaçaram, bateram e xingaram os filhos após as ações inadequadas deles.

A consequência para esse tipo de interação foi uma ocorrência maior de problemas de comportamento internalizantes nos adolescentes do grupo de risco após as práticas negativas maternas, tais como chorar e ficar triste. Por parte dos filhos desse grupo, também houve menor frequência de habilidades sociais para pedir desculpas e se explicar. Esse déficit comportamental foi influenciado por poucas ações maternas na reparação dos danos, o que foi detectado nas situações em que as mães identificaram o erro e não agiram para repará-lo.

O contrário ocorreu entre os adolescentes de não risco que apresentaram mais reações habilidosas, como pedir desculpas e explicar-se. Segundo Del Prette e Del Prette (2001), tal habilidade é importante na resolução de conflitos e na diminuição das mágoas nas relações interpessoais, podendo ser estimulada nos filhos a partir do modelo de comportamento dos pais (BOLSONI-SILVA, 2003). Quando os jovens veem seus pais pedir desculpas, aos poucos aprendem a ser responsáveis por seus próprios erros também (GRAY, 2003).

As dificuldades das mães da amostra de risco para lidar com comportamentos indesejados dos filhos foram evidenciadas pela utilização excessiva de práticas negativas ativas ao detectar que os jovens fizeram coisas das quais elas não gostaram. E após tais práticas negativas maternas, os adolescentes reagiram de modo problemático. Esses resultados são coerentes com o estudo de Webster-Straton e Herbert (1994) que, de modo geral, disseram que os pais das crianças com problemas de comportamento agem de forma mais violenta e crítica quando têm a intenção de disciplinar o filho. No entanto, acabam reforçando comportamentos inadequados e punindo as habilidades sociais deles (WEBSTER-STRATON, HERBERT, 1994).

A dificuldade para lidar com o comportamento indesejado dos filhos é explicada por Soenens et al. (2005) como relacionada às expectativas parentais exigentes. Esse processo é denominado de perfeccionismo parental mal adaptado, pois faz com que os pais, ao se depararem com os comportamentos inadequados dos filhos, ajam de forma rígida e impaciente na tentativa de controlar o adolescente. Em consequência, estes reagem agressivamente.

A estratégia parental citada acaba mantendo e até mesmo intensificando os problemas de comportamento do adolescente (SOENENS et a.l, 2005), como pode ser visto nas análises 
descritivas do grupo de risco. Os filhos agiram de forma problemática (brigando, mentindo, fumando, gazeando aulas, não estudando), e as mães, na tentativa de controle, gritaram e brigaram. Aqueles reagiram com comportamentos problemáticos externalizantes (enfrentar a mãe, desobedecer, mentir e fazer birras) e internalizantes (ficar quieto e ignorar). Logo, essa situação interativa evidenciou a funcionalidade do comportamento de mães e filhos, bem como o processo familiar coercitivo (PATTERSON; REID; DISHION, 1992; SIDMAN, 2001).

A frequência de disponibilidade e cooperação (HS) e o comportamento de choro (externalizante) dos filhos, após a ação desaprovada pela mãe, foi semelhante em ambos os grupos. Os destaques estão para a falta de disponibilidade e o comportamento de choro que, depois dos erros serem detectados, são consideradas reações naturais e inofensivas para esse tipo de situação. Sendo assim, as pessoas, ao perceberem que cometeram falhas, geralmente apresentam, mesmo que momentaneamente, um rebaixamento da auto-estima (DEL PRETTE; DEL PRETTE; 2001).

O entendimento conjugal envolve aspectos relacionados à concordância do casal quanto às práticas educativas. A relação entre o casal é, por isso, apontada pela literatura como um fator influente do comportamento dos filhos (BOLSONI-SILVA, 2003; WEBSTER-STRATTON; HERBERT, 1994).

De modo geral, os grupos apresentaram resultados semelhantes em relação ao entendimento conjugal, exceto no fato de que as mães do grupo de risco conversaram sobre as dificuldades e brigaram na frente dos filhos. Isso, porém, não ocorreu entre as mães do grupo de não risco. Para aquelas com frequência se falava sobre os comportamentos inadequados na presença dos filhos, o que tornava a situação aversiva ao adolescente. Sobre esse assunto, para Bolsoni-Silva (2003), a atitude do casal perante o ato de conversar sobre as dificuldades e os problemas do filho na ausência dele é mais adequada, pois assim os pais podem trocar informações e chegar a um acordo, evitando a exposição desnecessária do filho aos conflitos (BOLSONI-SILVA, 2003).

O fato das mães do grupo de risco conversarem sobre os problemas do filho na presença deles pode dar margem à manutenção ou intensificação dos comportamentos problemáticos, principalmente quando há divergências entre o casal (BOLSONI-SILVA, 2003). O filho, além de se sentir mal nessa situação (SHELTON; HAROLD, 2008), pode aprender a manipular os pais (GOMIDE, 2004) quando percebe que eles não estão de acordo. O estudo de Shelton e Harold (2008) mostra que, nesses casos, quando os conflitos e as 
divergências são expostos ao adolescente com frequência, motiva-se o desenvolvimento de problemas de comportamento inter e externalizantes.

Os demais aspectos de entendimento do casal foram semelhantes nos dois grupos. $\mathrm{O}$ fato dos pais terem pensamentos e crenças sobre educação similares foram mais frequentes do que as divergências sobre a forma de educar. Por outro lado, foram pouco frequentes a agressividade do cônjuge, a HSE-P para conversar na ausência do filho, a conversa, a admissão de erros e o pedido de desculpas na relação entre o casal.

A análise dos resultados permite dizer que as semelhanças em relação às crenças e aos objetivos do casal são benéficas aos filhos. É uma indicação de que a concordância entre o casal previne problemas de comportamento dos filhos, o que está em consonância com os achados de Bolsoni-Silva (2003).

A baixa frequência de agressividade entre o casal é benéfica aos filhos de ambos os grupos, já que não estimula a aprendizagem de padrões de comportamento agressivos nos jovens. Segundo Marinho (2001, 2003), os filhos de pais que apresentam comportamentos agressivos podem vir a apresentar a mesma conduta por meio da aprendizagem por modelação.

A baixa frequência do casal para falar sobre o jovem em sua ausência não teve um resultado positivo para este em ambos os grupos. No entanto, esse resultado pode ser interpretado de forma diferente no grupo de risco e não risco. As mães deste grupo justificaram a pouca frequência de conversa na ausência do filho porque havia concordância entre os pais. Naquele grupo, o de risco, as mesmas não conversavam sobre os problemas dos filhos e nem brigavam na frente deles. Nesse quesito, as práticas das mães de risco foram ainda mais prejudiciais aos filhos.

Quanto ao resultado sobre a pouca frequência da habilidade do casal para conversar, admitir erros e pedir desculpas, observou-se que as dificuldades foram detectadas em ambos os grupos. É importante lembrar que essa habilidade educativa parental é para os pais um modo de ensinar aos filhos os comportamentos que reparam os danos causados por suas ações (BOLSONI-SILVA, 2003).

Em relação à análise das dimensões globais do RE-HSE-P, aponta-se para alguns aspectos significativos: a expressão de sentimentos negativos por parte das mães, a dificuldade materna para cumprir promessas, a concordância entre as ideias do casal, a ação dos filhos para fazer o que as mães não gostam e o comportamento materno para fazer perguntas sobre sexualidade. 
A dificuldade para cumprir promessas foi maior entre as mães do grupo de risco. Já a concordância do casal teve maior incidência entre as mães do grupo de não risco e as estas também fizeram mais perguntas aos filhos sobre sexualidade. Só não houve diferença entre os grupos de mães nos quesitos expressão de sentimentos negativos e consideração sobre o que os filhos fazem que elas não gostam. Isso sugere que o grupo de risco apresenta reservas comportamentais e de que as mães do grupo de não risco também têm as suas dificuldades na relação com os filhos.

A dificuldade para cumprir promessas das mães do grupo de risco pode estar associada ao maior uso de estratégias coercitivas para tentar controlar os filhos. Por exemplo, fazer uso de ameaças, mas não efetivá-las. Dessa forma, traz-se à tona a aversão ao clima familiar, como foi verificado na pesquisa de Bolsoni-Silva (2003).

A concordância entre os pais é um fator de proteção contra problemas de comportamento do filho (BOLSONI-SILVA, 2003) e está presente na amostra do grupo de não risco. As mães desse grupo também conversaram mais sobre sexualidade com seus filhos, o que prova que esse é um método eficaz na prevenção de doenças sexualmente transmissíveis e uma forma de evitar o início precoce da vida sexual. Logo, tem-se na conversa uma habilidade benéfica à saúde do adolescente (DICLEMENTE et al., 2001; ROMER et al., 1997).

As análises dos resultados gerais obtidos pelo RE-HSE-P são complementares às análises globais, já que ambas apresentaram convergência entre os resultados. A análise geral encontrou diferenças estatísticas significativas para todas as áreas avaliadas. As mães do grupo de não risco apresentaram maior frequência nas situações de contexto interativo com seus filhos do que as de risco, maior frequência nas habilidades sociais educativas - HSE-P do que as de risco e maior frequência de práticas positivas do que as de risco.

Dos aspectos apontados, as situações de interação, denominadas contexto, foram mais frequentes entre as mães e seus filhos do grupo de não risco. Essas mães interagiram mais, consequentemente apresentaram uma relação de proximidade maior com seus filhos.

Alguns autores (STANTTIN; KERR, 2000) apoiam a aproximação dos pais com seus filhos nas mais diversas situações e não somente nos momentos críticos. O fato das mães de não risco apresentarem essa relação de proximidade com os seus filhos aumentou a chance daquelas de serem ouvidas e respeitadas por estes. Como foi observado na maior parte das situações de interação do grupo de não risco, os adolescentes mostraram-se com mais habilidades sociais e com menos problemas de comportamento. 
As mães de não risco também apresentaram mais habilidades sociais educativas HSE-P -, consideradas práticas positivas, nas interações com seus filhos. Isso significa que essas mães utilizavam mais recursos educativos estimuladores das habilidades sociais do que instrumentos punitivos para educar seus adolescentes.

Os resultados apontados são coerentes com os da literatura. As pesquisas apontam para a importância da educação positiva focada nos aspectos positivos do filho, nas suas potencialidades e qualidades, ao invés da educação centrada na punição de comportamentos inadequados (PATTERSON; REID; DISHION, 1992; SIDMAN, 2001; BOLSONI-SILVA, 2003; GOMIDE, 2004). Os grupos de risco para problemas de comportamento de crianças e adolescentes são caracterizados como compostos por pais que se utilizam de excessiva punição na educação de seus filhos (GOMIDE, 2006; GOMIDE et al., 2005; PINHEIRO, 2003).

As mães do grupo de risco apresentaram mais práticas negativas, maior frequência de práticas negativas e maior frequência do total negativo do que as do grupo de não risco. Isso significa que as mães daquele grupo abusaram do uso e da variabilidade das práticas parentais negativas. Estas práticas foram caracterizadas como as que promoveram a diminuição da variabilidade do comportamento dos filhos e, por isso, são prejudiciais ao adolescente na aprendizagem das habilidades sociais. Pensando assim, é vital a aquisição de habilidades sociais para o convívio em sociedade, porque aquele adolescente excessivamente punido por suas escolhas e atitudes pode ingressar em diversas situações de risco. Entre elas, cita-se a apresentação de comportamentos problemáticos, a união a grupos desviantes e a possibilidade de entrar em depressão (PATTERSON; REID; DISHION, 1992).

Como consequência das práticas maternas negativas, os adolescentes do grupo de risco apresentaram maior frequência de problemas de comportamento e menor de habilidades sociais. O contrário ocorreu entre os adolescentes do grupo de não risco, o que mostra que os jovens deste grupo provavelmente foram beneficiados pelas habilidades sociais educativas maternas. Pelo menos é o que foi observado nas interações em que tais adolescentes mostraram mais disposição e foram cooperativos, mais carinhosos e mais prestativos. Já os adolescentes do grupo de risco foram prejudicados pelas práticas maternas negativas, pois estas estavam muito focadas nos problemas de comportamento, o que promoveu a manutenção das dificuldades do adolescente, não dando ao jovem alternativa para mudar e melhorar suas relações.

As correlações realizadas na avaliação das variáveis do RE-HSE-P dentro de cada grupo mostraram que há maior regularidade ou estabilidade nas habilidades sociais educativas 
maternas e nas práticas utilizadas dentro do grupo de não risco e maior irregularidade dentro do grupo de risco. Isso significa que as mães do grupo de não risco, apesar de terem utilizado algumas práticas negativas com pouca frequência, fizeram-no de forma mais clara e contingente ao comportamento do adolescente.

As mães do grupo de não risco também foram mais afetivas e contingentes ao comportamento habilidoso dos adolescentes, isto é, reforçaram as habilidades sociais dos seus filhos. Já entre as mães do grupo de risco houve correlações incoerentes, o que indica que elas apresentaram inconsistência nas práticas educativas, já que ora puniam ora reforçavam os comportamentos habilidosos e problemáticos. Criou-se um ambiente instável para os adolescentes desse grupo que, consequentemente, apresentaram problemas de comportamento com mais frequência, como mostram os resultados.

\subsection{COMPORTAMENTOS DOS ADOLESCENTES}

A maior investigação a respeito do repertório comportamental dos adolescentes foi realizada pelo Child Behavior Checklist - CBCL- e os resultados confirmaram os dados referentes ao comportamento dos adolescentes encontrados pelo RE-HSE-P. As análises obtidas pelo CBCL mostraram que a frequência dos problemas de comportamento internalizantes e externalizantes foram maiores para os adolescentes do grupo de risco. Destaca-se que a diferença entre os grupos foi estatisticamente significativa para os problemas internalizantes, externalizantes e para o total de problemas do CBCL.

Os adolescentes do grupo de risco apresentaram maior frequência de participantes classificados como clínicos e borderline que os adolescentes do grupo de não risco. Já os adolescentes do grupo de não risco apresentaram maior frequência de classificação como não clínicos do que os de risco. Isso significa que os adolescentes do grupo de risco apresentaram maior frequência de problemas de comportamento segundo o CBCL.

Esses resultados descritos estão em consonância com os do estudo de Salvo, Silvares e Toni (2005). Eles afirmaram que os adolescentes sob influência de práticas parentais positivas apresentaram maior competência social e menor frequência de problemas de comportamento internalizantes. Já os jovens sob efeito de práticas negativas tiveram problemas de atenção, problemas internalizantes e problemas de comportamento gerais do CBCL (SALVO, SILVARES, TONI, 2005). 
Os dados desse estudo reiteram os resultados encontrados neste trabalho. Os filhos de mães do grupo de risco apresentaram maior frequência de problemas de comportamento segundo o CBCL. Os adolescentes do grupo de não risco, que estavam sob influência de habilidades sociais educativas maternas com maior frequência, em detrimento das práticas negativas, apresentaram menor frequência de problemas de comportamento segundo o CBCL.

Em síntese, os resultados discutidos indicam que as interações do grupo de não risco foram mais reforçadoras e incentivadoras da aprendizagem de habilidades sociais dos adolescentes. As mães desse grupo apresentaram maior frequência de habilidades sociais e menor de práticas negativas. Pôde-se observar que os filhos reagiram às habilidades sociais educativas maternas de forma habilidosa, incentivando as mães a interagirem com eles. As mães desse grupo utilizaram de práticas negativas com pouca frequência. Quando o fizeram, utilizaram a punição negativa, que consiste na retirada de privilégios dos filhos, o que é menos prejudicial ao desenvolvimento do filho.

Ainda em relação às mães do grupo de não risco, elas não utilizaram práticas negativas ativas como gritar, xingar, ameaçar e humilhar os filhos. Como mostram as pesquisas, essas práticas causam extremo prejuízo ao desenvolvimento das habilidades do filho. Cita-se os problemas de comportamento, por exemplo (GOMIDE, 2003; PATTERSON, REID, DISHION, 1992). O uso de práticas negativas foi pouco frequente no grupo de não risco, pois os filhos quase não apresentaram problemas de comportamento clínicos e borderline.

Os resultados gerais do grupo de risco são contrários aos da amostra do grupo de não risco, pois as mães fizeram mais uso de práticas negativas e menos de habilidades sociais educativas. Os filhos apresentaram maior frequência de problemas de comportamento e menor de habilidades sociais. O presente estudo mostrou, no entanto, que as mães e os filhos desse grupo também apresentavam reservas comportamentais que poderiam ser estimuladas para melhorar a relação e as habilidades das mães e dos filhos. 


\section{CONSIDERAÇÕES FINAIS}

O presente estudo realizou a análise funcional das interações entre as mães e os seus filhos adolescentes, na qual foram investigadas as habilidades sociais educativas utilizadas pelas mães e o repertório comportamental dos adolescentes dos grupos de risco e não risco. Conforme a hipótese, os relatos dos adolescentes sobre as práticas maternas, obtidos pelo Inventário de Estilo Parental Materno - IEP -, foram confirmados pelas informações dadas pelas mães nas entrevistas. Essas declarações foram pautadas no Roteiro de Entrevista de Habilidades Sociais Educativas Parentais - RE-HSE-P.

Os dados das entrevistas foram consoantes com as hipóteses do estudo. Foi possível identificar que as mães do grupo de não risco apresentaram maior frequência e variabilidade de habilidades sociais educativas - HSE-P - do que as mães do grupo de risco em todos os aspectos investigados pelo RE-HSE-P. Já as mães do grupo de risco utilizaram mais frequentemente práticas negativas ativas em todas as suas interações, tais como ficar brava e gritar com seus filhos, o que não ocorreu no grupo de não risco. Outro dado interessante foi o de que as mães do grupo de risco xingaram os seus filhos em determinadas situações. Essa é uma prática negativa que também não fez parte das ações maternas do grupo de não risco.

As relações funcionais entre o comportamento materno e o filial foram evidenciadas pela análise dos dados obtidos com o RE-HSE-P. Em consonância com as hipóteses, as mães do grupo de risco emitiram mais práticas negativas, menos HSE-P e os seus filhos reagiram de forma problemática na maior parte das interações. As mães de não risco emitiram mais HSE-P, menos práticas negativas, os seus filhos, consequentemente, apresentaram mais habilidades sociais nas interações.

Os comportamentos dos adolescentes foram investigados pelo RE-HSE-P e confirmados pelo Child Behavior Checklist - CBCL. Em consonância com as expectativas deste estudo, os dois instrumentos indicaram a maior presença de habilidades sociais nos adolescentes do grupo de não risco que nos do grupo de risco. Assim, houve maior incidência de problemas de comportamento nos adolescentes do grupo de risco que nos do grupo de não risco.

De acordo com as hipóteses, as investigações mais detalhadas da relação entre mães e filhos sobre comunicação, expressão de sentimentos e de enfrentamento e estabelecimento de limites mostraram que o grupo de não risco foi mais habilidoso do que o de risco. No entanto, houve algumas semelhanças entre os grupos no que diz respeito às reservas comportamentais 
do grupo de risco e as dificuldades apresentadas pelo grupo de não risco. Tais dados são importantes, visto que contribuem com a estruturação de grupos de intervenção para ajudar mães, pais e filhos.

As diferenças detectadas na comunicação mostraram que a interação foi mais rica no grupo de não risco do que no de risco. As mães de não risco conversaram mais com seus filhos e falaram sobre os mais diversos assuntos. Elas também fizeram mais perguntas sobre temas de interesse dos adolescentes e os deixaram mais à vontade para fazer perguntas sobre sexualidade. Como resultado, os filhos apresentaram mais habilidades sociais para conversar, fazer perguntas gerais e falar sobre sexo. O contrário se deu na comunicação do grupo de risco em que as mães centraram suas conversas e perguntas nos problemas de comportamento dos filhos. Isso motivou reações não habilidosas e até mesmo problemáticas dos adolescentes, tais como não falar nada, interromper a conversa ou responder em tom agressivo.

Semelhanças nas interações de comunicação foram constatadas em relação às reservas comportamentais dos filhos de risco. Apesar de terem apresentado reações problemáticas, mostraram habilidades sociais nas conversas. Em relação às reservas das mães, elas também apresentaram habilidades sociais educativas ao conversar com seus filhos sobre a concepção do que é certo e errado e ao perguntar sobre diversos assuntos aos jovens. Essas ações habilidosas por parte das mães de risco, no entanto, foram prejudicadas pelas práticas coercitivas utilizadas pelas mesmas concomitantemente às práticas positivas.

$\mathrm{Na}$ interação de enfrentamento e expressão de sentimentos, a diferença entre os grupos se refere ao fato de mães e filhos do grupo de não risco terem agido, em geral, de forma mais habilidosa do que os do grupo de risco. As mães daquele grupo expressaram sentimentos negativos de forma assertiva e sentimentos positivos com maior frequência e maior habilidade. Nas situações em que foi necessário a expressão de opiniões, isso se deu de forma estimulante para as mães e para os filhos, pois ambos apresentaram mais habilidades sociais. Além disso, as mães foram mais carinhosas. O contrário aconteceu no grupo de risco, já que as mães expressaram sentimentos negativos de forma agressiva (não habilidosa) e poucos sentimentos positivos. Para expressar opiniões, estas mães se referiam aos problemas de comportamento dos filhos e fizeram carinho neles com pouca frequência. Consequentemente, os filhos apresentaram menos habilidades sociais na maior parte das interações com expressão de sentimentos e enfrentamento.

As similaridades entre os grupos, na categoria expressão de sentimentos, ocorreram porque os filhos obedeceram às mães após a expressão de sentimentos negativos e ao fato dos adolescentes não terem rejeitado o carinho ofertado por suas mães. Portanto, os filhos gostam 
de receber carinho, mas faltam oportunidades para que os adolescentes do grupo de risco vivam esse tipo de experiência.

Também foram identificadas diferenças em relação ao estabelecimento de limites. As mães do grupo de não risco foram mais coerentes do que as do grupo de risco. Tanto as mães quanto os filhos do grupo de não risco se mostraram mais habilidosos. As mães foram mais habilidosas ao aplicarem as regras e mostrarem as consequências para o seu cumprimento, e os filhos, no sentido de aceitá-las, de pedir desculpas e de tentar remediar as ações inadequadas. O contrário aconteceu no grupo de risco, pois as mães não se mostraram habilidosas. Elas não souberam discriminar os motivos na aplicação de limites e não apresentarem ações consistentes. Consequentemente, os filhos apresentaram problemas de comportamento, como, por exemplo, ficar bravo, fazer birra, responder em tom agressivo e fazer o que a mãe proíbe às escondidas. A falta de discriminação materna para estabelecer as diretrizes educacionais de seus filhos traz extremo prejuízo ao indivíduo, pois acarreta a inconsistência das práticas educativas que é promotora de problemas de comportamento em adolescentes.

Em relação às habilidades do casal, houve semelhanças e divergências entre os grupos. As convergências se referem ao fato das mães de ambos os grupos detectarem que o casal pensa de forma parecida quanto às práticas educativas. A divergência entre os grupos está no fato das mães do grupo de risco conversarem sobre os problemas do filho e brigarem na frente dele, o que não ocorreu no grupo de não risco. Algumas dificuldades foram detectadas em ambos os grupos, como, por exemplo, a pouca habilidade do casal para admitir erros e pedir desculpas.

Apesar das mães e dos filhos do grupo de risco terem apresentado déficits de habilidades sociais educativas e de habilidades sociais na maior parte das interações, ambos apresentaram reservas comportamentais em todas as áreas avaliadas. Em outras palavras, as mães e os adolescentes do grupo de risco apresentaram habilidades sociais com pouca frequência, motivo pelo qual essas mães necessitariam do direcionamento dado pelos grupos de intervenção. Também as mães e os filhos do grupo de não risco apresentaram algumas dificuldades que também podem ser aprimoradas pelos grupos de orientação para pais e de estimulação de habilidades sociais para adolescentes.

O presente estudo apresenta algumas particularidades, como o fato dos dados terem sido coletados a partir dos relatos verbais dos adolescentes e de suas mães a respeito de suas interações, o que é bastante pertinente em trabalhos de avaliação em contexto clínico, sobretudo por se tratar de relato espontâneo, cujos dados colhidos podem significar que são os 
comportamentos de cada interlocutor e as interações sociais contingentes que mais controlam as respostas de mães e filhos. Outra particularidade está na investigação da história de vida de 48 pessoas, 24 mães e 24 filhos adolescentes que contaram sobre suas vidas, uma vez que os filhos descreveram suas mães e essas relataram sobre suas interações com os filhos, sobre os seus comportamentos e sobre os comportamentos emitidos pelos seus filhos

Este estudo contribui para um maior entendimento das relações funcionais entre as mães e os filhos adolescentes e ajuda a detectar também as contingências entrelaçadas presentes nessas interações. Essas contingências possibilitam a identificação da influência de determinados comportamentos maternos sobre determinados comportamentos dos filhos e vice-versa.

Outro benefício atribuído a este trabalho refere-se à aplicação do instrumento REHSE-P às mães de filhos adolescentes. O instrumento mostrou-se adequado para tal público, tendo em vista que até então o RE-HSE-P havia sido aplicado a mães e pais de filhos préescolares e de ensino fundamental (BOLSONI-SILVA, 2003; 2009).

Um resultado importante encontrado pelo estudo foi à concordância obtida entre os instrumentos utilizados. O IEP, o RE-HSE-P e o CBCL mostraram-se instrumentos adequados na avaliação das práticas, das habilidades sociais educativas maternas e do comportamento do adolescente.

De modo geral, esta pesquisa atingiu suas metas, em especial o objetivo de traçar um perfil das interações entre mães e filhos adolescentes, os quais podem subsidiar pesquisas futuras, como, por exemplo, (a) realizar a investigação com um número maior de mães e de filhos adolescentes, para que seja possível traçar um perfil epidemiológico; (b) realizar pesquisas com a participação dos pais dos adolescentes, os quais são investigados pelas demais pesquisas (GOMIDE, 2006; BOLSONI-SILVA, 2003) e também são relatados por esses estudos como tendo um papel diferenciado do papel das mães na interação com os filhos; (c) fazer estudos sobre as intervenções para as mães e os pais de adolescentes, nas quais sejam enfrentadas as dificuldades e aprimoradas as habilidades das mães, dos pais e dos adolescentes; (d) fazer pesquisas com observação do comportamento das mães, dos pais e dos filhos, tendo em vista que as pesquisas de observação são enfatizadas por autores da análise do comportamento (SKINNER, 1998) como uma ferramenta útil para fidedignidade dos dados. 


\section{REFERÊNCIAS}

ACHENBACH, Thomas. M.; EDELBROCK, Craig. S. The child behavior profile: II. Boys aged 12-16 and girls aged 6-11 and 12-16. Journal of consulting and clinical psychology, 47 (2), p.223-233, 1979.

ACHENBACH, T.M. Manual for the youth self-report and 1991 profile. Burlington: University of Vermont, Departament of psychiatry, 1991.

ALBERTI, Robert E; EMMONS, Michael. Como se tornar mais confiante e assertivo: aprenda a defender suas idéias com tranqüilidade e segurança. Rio de Janeiro: Sextante, $1970 / 2008$.

ANDERY, Maria Amalia Pie Abib; MICHELETTO, Nilza; SÉRIO, Tereza Maria de Azevedo Pires. A análise de fenômenos sociais: esboçando uma proposta para a identificação de contingências entrelaçadas e metacontingências. Revista brasileira de análise do comportamento, v.1, n.2, p.149-164, 2005.

ARÓN, Ana María; MILICIC, Neva M. Viver com os outros: programa de desenvolvimento de habilidades sociais. Tradução: Jonas Pereira dos Santos. Campinas: Editorial Pscy II, 1994.

AVANCI, Joviana Q.; ASSIS, Simone G.; OLIVEIRA, Raquel V.C; FERREIRA, Renata M.; PESCE, Renata P. Fatores associados aos problemas de saúde mental em adolescentes. Psicologia: teoria e pesquisa, v.23, n.3, Brasília, jul/set.2007.

BANDURA, Albert. Modificação do comportamento. Rio de Janeiro: Interamericana, 1969/1979.

BARAKAT, Ibtisam S.; CLARK, Janet A. Positive discipline and child guidance. Human development and family studies, February 1, 2001.

BAUM, William.Compreender o behaviorismo: ciência, comportamento e cultura. Porto Alegre: Artmed, 1999.

BAUMRIND, Diana The discipline controversy revisited (in Parenting) Family relations, v. 45, n. 4, p. 405-414, 1996. 
BAUMRIND, Diana Effects of authoritative parental control on child behavior. $\underline{\text { Child }}$ development, v. 37, p.887-907, 1966.

BOLSONI-SILVA, Alessandra T. Estudos de validação e confiabilidade do roteiro de entrevista de habilidades sociais educativas parentais (RE-HSE-P) Tese de pós doutorado apresentada à Faculdade de Filosofia, Ciências e Letras de Ribeirão Preto da USP. 108 p, 2009.

BOLSONI-SILVA, Alessandra T. Roteiro de entrevista de habilidades sociais educativas parentais (RE-HSE-P): categorias e testagens preliminares. Em: Weber, Lídia Natália D. (Org.) Família e desenvolvimento humano. Curitiba: Juruá. p.145- 158, 2008.

BOLSONI-SILVA, Alessandra T., SALINA-BRANDÃO, Alessandra, VERSUTIESTOQUE, Fabiana. M.; ROSIN-PINOLA, Andréia. R. Avaliação de um programa de intervenção de habilidades sociais educativas parentais. Psicologia ciência e profissão, 28 (1), p.18-33, 2008.

BOLSONI-SILVA, Alessandra T.; MARTURANO, Edna M.. A qualidade da interação positiva e da consistência parental na sua relação com problemas de comportamentos préescolares, habilidades sociais educativas parentais e problemas de comportamento. Revista interamericana de psicologia/ Interamerican journal of psychology, vol 41, 3, 2-10, 2007.

BOLSONI-SILVA, Alessandra T. Roteiro de entrevista de habilidades sociais educativas parentais adaptação de Bolsoni-Silva 2007, não publicado, 2007.

BOLSONI-SILVA, Alessandra T.; MARTURANO, Edna M. A qualidade da interação "pais e filhos e sua relação com problemas de comportamentos de pré-escolares". Em:

BANDEIRA, M.; DEL PRETTE, Z.A.P.; DEL PRETTE, A. (Org.) Estudos sobre habilidades sociais e relacionamento interpessoal. Casa do Psicólogo: São Paulo, 2006.

BOLSONI-SILVA, Alessandra T. Habilidades sociais educativas, variáveis contextuais e problemas de comportamento: comparando pais e mães de pré-escolares. Tese de doutorado apresentada à Faculdade de Filosofia, Ciências e Letras de Ribeirão Preto da USP. 210 p. 2003.

BOLSONI-SILVA, Alessandra T.; DEL PRETTE, Almir. Problemas de comportamento: um panorama da área. Revista brasileira de terapia comportamental e cognitiva, V, n. 2, p.91-103, 2003.

BOLSONI-SILVA, Alessandra T.; DEL PRETTE, Almir; OISHI, Jorge. Habilidades sociais de pais e problemas de comportamento de filhos. Argumento, V, n. 9, p.11-29, abril 2003. 
BOLSONI-SILVA, Alessandra T.; MARTURANO, Edna M. Práticas educativas e problemas de comportamento: uma análise à luz das habilidades sociais. Estudos de psicologia, 7 (2), p. 227-235, 2002.

BORAWSKI, Elaine A.; IEVENS-LANDIS, Carolyn E.; LOVEGREEN, Loren D.; TRAPI, Erika S. Parental monitoring, negotiated unsupervised time, and parental trust: the role of perceived parenting practices in adolescent health risk behaviors. Journal of adolescent health, 33, p. 60-70, 2003.

CABALLO, Vicente E. Manual de avaliação e treinamento de habilidades sociais. São Paulo: Editora Santos. 408 p., 2003.

CIA, Fabiana; PAMPLIN, Renata Christian O.; DEL PRETTE, Zilda A. P. Comunicação e participação pais-filhos: correlação com habilidades sociais e problemas de comportamento dos filhos. Paidéia, 16, 35, p. 395-406, 2006.

DEL PRETTE, Almir; DEL PRETTE, Zilda A. P. Um sistema de categorias de habilidades sociais educativas. Paidéia, 18, 41, p. 517-530, 2008.

DEL PRETTE, Almir; DEL PRETTE, Zilda A. P. Psicologia das habilidades sociais na infância. Petrópolis: Vozes, 270 p., 2005.

DEL PRETTE, Almir; DEL PRETTE, Zilda A. P. Habilidades sociais cristãs: desafios para uma nova sociedade. Petrópolis:Vozes, 2003.

DEL PRETTE, Almir; DEL PRETTE, Zilda A. P. Psicologia das relações interpessoais: Vivências para o trabalho em grupo. Petrópolis:Vozes, 231 p., 2001.

DEL PRETTE, Almir; DEL PRETTE, Zilda A. P. Psicologia das habilidades sociais: Terapia e educação. Petrópolis: Editora Vozes, 206 p., 1999.

DIAS, Ana Cristina Garcia; GOMES, William. Conversas sobre sexualidade na família e gravidez na adolescência: a percepção dos pais. Estudos de psicologia, 4, 1, p.79-106, 1999.

DICLEMENTE, Ralph. J.; WINGOOD, Gina M.; CROSBY, Richard; SIONEAN, Catlain; COBB, Brenda K.; HARRINGTON, Kathy; DAVIES, Susan; HOOK III, Edward; OH, Kim. Parental monitoring: association with adolescents'risk behaviors. Pediatrics, 107, 1363-1368, 2001. 
DISHION, Thomas.J.; MCMAHON, Robert.J. Parental monitoring and the prevention of child and adolescent problem behavior: a conceptual and empirical formulation. Clinical child and family psychology review, v. 1, n.1, 1998.

FALCONE, Eliane. A evolução das habilidades sociais e o comportamento empático. Em: Silvares, Edwiges Ferreira de Mattos (Org.) Estudos de caso em psicologia clínica comportamental infantil I. Campinas, SP: Papirus, p.49-78. 2000.

FERSTER, Charles B.; CULBERSTON, S.; PERROT-BOREN, M.C. Princípios do comportamento. São Paulo: Hucitec-Edusp, 1977.

FLETCHER, Anne C.; STEINBERG, Laurence; WILLIAMS-WHEELER, Meeshay. Parental influences on adolescent problem behavior: revisiting Stattin and Kerr. Child development, v.75, n. 3, p. 781-796, may/june, 2004.

FOREHAND, Rex; LONG, Nicholas. Como educar crianças de temperamento forte: programa clinicamente comprovado de cinco semanas para pais de crianças de dois a seis anos de idade. São Paulo: M. Books, 259 p., 2003.

GELFAND, Donna M.; HARTMAN, Donald P. Child behavior analysis and therapy. USA: Pergamon General Psychology Series, 332 p., 1975.

GOMIDE, Paula I. C. Manual do inventário de estilos parentais: modelo teórico, manual de aplicação, apuração e interpretação. Vozes: Petrópolis, 96 p., 2006.

GOMIDE, Paula I. C.; SALVO, Caroline G.; PINHEIRO, Débora D.; SABBAG, Gabriela M. Correlação entre práticas educativas, depressão, estresse e habilidades sociais Psico-USF, v. 10, n. 2, p. 169-178, jul./dez. 2005.

GOMIDE, Paula I. C. Pais presentes, pais ausentes. Vozes: Petrópolis. 86p., 2004.

GOMIDE, Paula I. C. Estilos Parentais e comportamento anti-social. Em: DEL PRETTE, A.; DEL PRETTE, Z. (Orgs). Habilidades Sociais, desenvolvimento e aprendizagem: questões conceituais, avaliação e intervenção. Campinas: Alínea, p. 21-60, 2003.

GOMIDE, Paula I. C. Menor infrator: a caminho de um novo tempo. Curitiba: Juruá, 173 p.,1998. 
GUILHARDI, H.J. Auto estima, auto confiança e responsabilidade. Em: BRANDÃO, Maria Z. S.; CONTE, Fátima C.S.; ,MEZZAROBA, Solange M. (Orgs.) Comportamento humano: tudo (ou quase tudo) que você precisa saber para viver melhor. Santo André, SP: ESETec Editores Associados, 2002.

HA, Thao; OVERBEEK, Geertjan; VERMULST Ad A.; ENGELS, Rutger C.M.E. Marital quality, parenting, and adolescente internalizing problems: a three-wave longitudinal study. Journal of family psychology, v. 23, n.2, p. 263-267, 2009.

HOFFMAN, Martin L. Discipline and Internalization of Values: Model, Rewiew and Comentaries. Developmental Psychlology, 30, 26-28, 1994.

LA TAILLE, Ives. O sentimento de vergonha e suas relações com a moralidade. Psicologia reflexão e crítica, v.15, n 1, 23-35, 2002.

LEWIS, Michael. Shame: the exposed self. New York: Free Press, 1992.

LOOS, Helga; FERREIRA, Sandra P.A.;VASCONCELOS, Fabíola.C. Julgamento: moral: estudo comparativo entre crianças institucionalizadas e crianças de comunidade de baixa renda com relação à emergência do sentimento de culpa. Psicologia: Reflexão e Crítica, 12, p. 47-70, 1999.

LUYCKX, Koen; SOENENS, Bart; BERZONSKY, Michael D.; VANSTEENKISTE, Maarten; GOOSSENS, Luc. Parental psychological control and dimensions of identity formation in emerging adulthood. Journal of family psychology, v. 21, n 3, p. 546-550, 2007.

MACCOBY, Eleanor E.; MARTIN, John A. Socialization in the context of the family:parentchild interaction. Em: HETERINGHTON, E.M. (Org.) Mussen Manual of Child Psychology 4. New York: Wiley, p.1-100, 1983.

MARINHO, Maria L. Comportamento anti-social infantil: questões teóricas e de pesquisa. Em: DEL PRETTE, A.; DEL PRETTE, Z. (Orgs). Habilidades Sociais, desenvolvimento e aprendizagem: questões conceituais, avaliação e intervenção. Campinas: Alínea, p.61-82, 2003.

MARINHO, Maria L. Subsídios ao terapeuta para análise e tratamento de problemas de comportamento em crianças: quebrando mitos. Em: MARINHO, Maria L.; CABALLO, Vicente E. (Orgs) Psicologia clínica e saúde. Londrina: UEL; Granada: APICSA, 2001. 
MCGUE, Matt; ELKINS, Irene; WALDEN, Brent; IACONO, William G. Perceptions of the parent-adolescent relationship: A longitudinal investigation. Developmental psychology, $\mathrm{v}$. 41, n.6, p. 971-984, 2005.

MONTAGU, Ashley. A natureza da agressividade humana. Rio de Janeiro: Zahar, 1978.

OTTA, Emma O sorriso e seus significados. Petrópolis: Vozes, 1994.

PACHECO, Janaína; ALVARENGA, Patrícia; REPPOLD, Caroline; PICCININI, César A.; HUTZ, SIMON, Claudio. Estabilidade do comportamento anti-social na transição da infância para a adolescência: uma perspectiva desenvolvimentista. Revista Psicologia Reflexão e Crítica, v. 18, n. 1, p. 55-61, 2005.

PACHECO, Janaína T. B.; SILVEIRA, Luiza Maria O. B.; SCHNEIDER, Andréia M. A. Estilos e práticas educativas parentais: análise da relação desses construtos sob a perspectiva do adolescente. Psico, Porto Alegre PUCRS, v. 39, n, 1, p.66-73, jan/mar, 2008.

PATTERSON, Gerald; REID, John; DISHION, Thomas Antisocial boys: comportamento anti-social. Santo André: ESETec, 2002.

PATTERSON, Gerald; REID, John; DISHION, Thomas Antisocial boys. Eugene: OR (USA), Castalia Publishing Company, 1992.

PETTIT, Gregory S.; LAIRD, Robert D.; DODGE, Kenneth A.; BATES, John E.; CRISS, Michael M. Antecedents and behavior- problem outcomes of parental monitoring and psychological control in early adolescence. Child Development, v. 72, n. 2, p. 583-598, march/april 2001.

PINHEIRO, Débora D.Estilo parental: uma análise qualitativa. Dissertação de mestrado nãopublicada em psicologia da infância e da adolescência, Universidade Federal do Paraná, 2003.

PLUNKETT, Scott W.; HENRY, Carolyn S.; ROBINSON, Linda C.; BEHNKE, Andrew; FALCON, Pedro C. Adolescent perceptions of parental behaviors, adolescent self-esteem, and adolescent depressed mood. Journal child family study, 16, p. 760-772, 2007.

PRUST, Laísa W.; GOMIDE, Paula I. C. Relação entre comportamento moral dos pais e dos filhos. Estudos em psicologia (Campinas), v.24, n.1, 53-60, 2007. 
REICHERT, Claudete B.; WAGNER, Adriana. Autonomia na adolescência e sua relação com os estilos parentais. Psico Porto Alegre PUCRS, v. 38, n.3, p.292-299, set/dez 2007.

REPPOLD, Caroline T.; PACHECO, Janaína; BARDAGI, Marúcia; HUTZ, Claudio S. Prevenção de problemas de comportamento e desenvolvimento de competências psicossociais em crianças e adolescentes: uma análise das práticas educativas e dos estilos parentais. Em: Hutz, C. (Org.) Situações de risco e vulnerabilidade na infância e na adolescência: aspectos teóricos e estratégias de intervenção. São Paulo: Casa do Psicólogo, p.7-51, 2002.

ROMER, Daniel; BLACK, Mauren; RICARDO, Izabel. Social influences on the sexual behavior of youth at risk for HIV exposure. Journal Public Health, 84, p. 977- 985, 1994.

ROSALES-RUIZ, Jesus; BAER, Donald M. Behavioral cusps: A developmental and pragmatic concept for behavior analysis. Journal of Applied Behavior Analysis, 30, p. 533$544,1997$.

ROSS, Alan O. Distúrbios psicológicos na infância: uma abordagem comportamental a teoria, pesquisa e terapêutica. Tradução de Auriphebo Berrance Simões. São Paulo: McGraw-Hill do Brasil, 281 p., 1979.

SALVO, Caroline G.; SILVARES, Edwiges F. M.; TONI, Plinio M.. Práticas educativas como forma de predição de problemas de comportamento e competência social. Estudos de psicologia, 22, 2, p. 187-195, abril/junho, 2005.

SHELTON, Katherine; HAROLD, Gordon T. Interparental conflict, negative parenting, and children's adjustment: bridging links between parent's depression and children's psychological distress. Journal of family psychology, v. 22, n. 5, p. 712- 724. 2008.

SIDMAN, Murray Coerção e suas implicações. Tradução de Maria Amália Andery e Tereza Maria Sério. Campinas: Livro Pleno. 2001.

SILVA, Alessandra T. B. Problemas de comportamento e comportamentos socialmente adequados: sua relação com as habilidades sociais educativas de pais. Dissertação de mestrado não-publicada, Universidade Federal de São Carlos, 2000.

SILVARES, Edwiges Ferreira de Mattos. Orientação sexual da criança. Em: BRANDÃO, Zilah; CONTE, Fátima Cristina de Souza; MEZZAROBA, Solange Maria Beggiato (Org.) Comportamento humano: tudo (ou quase tudo) que você gostaria de saber para viver melhor. Santo André: ESETec, 2002. 
SILVEIRA, Luiza M. O.; PACHECO, Janaína; CRUZ, Thiago; SCHNEIDER, Andréia A. Estratégias educativas desejáveis e indesejáveis: uma comparação entre a percepção de pais e mães de adolescentes. Aletheia, n.21, p.31-42, jan./jun.2005.

SKINNER, Burhuss F. Seleção por consequiências. Tradução de CANÇADO, Carlos R. X.; SOARES, Paulo G.; CIRINO, Sérgio. Revista brasileira de terapia comportamental e cognitiva, v.IX, n.1, p.129-137, 1981/2007

SKINNER, Burhuss F. Sobre o behaviorismo. 8 edição. São Paulo: Cultrix, 1974/2003

SKINNER, Burhuss F. Ciência e Comportamento Humano. 10 edição. São Paulo: Martins Fontes, 1953/1998.

SNYDER, James; PATTERSON, Gerald. Family interaction and delinquent behavior. In: Quay, H.C. (Ed.), Handbook of Juvenile Delinquency .New York: Wiley, p.216-243,1987.

SOENENS, Bart; ELLIOT, Andrew J.; GOOSSENS, Luc; VANSTEENKISTE, Maarten; LUYTEN, Patrick; DURIEZ, Bart. The intergenerational transmission of perfectionism: parent's psychological control as intervening variable. Journal of family psychology, v. 19, n.3, p.358-366, 2005.

STATTIN, Hakan; KERR, Margaret. Parental Monitoring: A Reinterpretation. Child Development, 71, 4, p. 1072-1085, 2000.

STEINBERG, Laurence; LAMBORN, Susie D.; DARLING, Nancy; MOUNTS, Nina S.; DORNBUSCH, Sanford M.. Over time changes in adjustment and competence among adolescents from authoritative, authoritarian, indulgent, and neglectful families. $\underline{\text { Child }}$ development, 65, p. 754-770, 1994.

TEIXEIRA, Marco A. P.; OLIVEIRA, Adriano M.; WOTTRICH, Shana H. Escalas de práticas parentais (EPP): avaliando dimensões de práticas parentais em relação a adolescentes. Psicologia: reflexão e crítica, 19, 3, p. 433-441, 2006.

WEBER, Lídia Natália Donbrianzkyj. Eduque com carinho: equilíbrio entre amor e limites. Curitiba: Juruá. 2007

WEBER, Lídia Natália Donbrianzkyj; SALVADOR, Ana Paula Viezzer; BRANDENBURG. Olívia Justen. Programa de qualidade na interação familiar (PQIF): orientação e treinamento

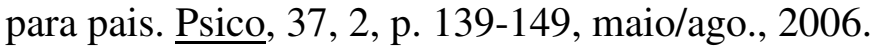


WEBER, Lídia Natália Donbrianzkyj; SALVADOR, Ana Paula Viezzer; BRANDENBURG. Olívia Justen; ZOCCHE, Claudia Regina Endo. Famílias que maltratam: uma tentativa de socialização pela violência. PsicoUSF, v.7, n.2, p.163-173, jul-dez, 2002.

WEBSTER- STRATTON, Carolyn; HERBERT, Martin. Troubled families, problems children: working with parents a collaborative process. Oxford: Wiley. 1994. 
APÊNDICES 
APÊNDICE A - Carta para Secretaria de Estado da Educação do Paraná (SEED) para autorização da pesquisa

\section{À Yvelise Freitas de Souza Arco-Verde}

Venho por meio desta, solicitar a autorização desta instituição para a realização da pesquisa: "Estilos parentais, habilidades sociais e problemas de comportamento em adolescentes”. Para esta autorização a pesquisadora, mestranda em psicologia do Programa Psicologia do Desenvolvimento e Aprendizagem da Universidade Estadual Paulista- UNESPBauru, abaixo assinado está encaminhando o projeto da pesquisa com os instrumentos a serem utilizados para avaliação e autorização da Secretaria de Estado da Educação do Paraná (SEED).

A pesquisa constará de duas fases. Na primeira fase será realizada a aplicação dos questionários sobre as práticas educativas parentais e sobre os comportamentos autoobservados em adolescentes estudantes de $6^{\mathrm{a}}$., $7^{\mathrm{a}}$. e $8^{\mathrm{a}}$. séries de colégios estaduais e/ou municipais de Curitiba. A segunda fase será realizada a partir da seleção de algumas mães dos participantes (aproximadamente 50), as mesmas serão convidadas para uma entrevista estruturada sobre a relação pais e filhos e a responderem a dois questionários: um sobre práticas educativas e outro sobre os comportamentos que observa em seu (sua) filho(a) participante.

Estes questionários e a entrevista serão o meio de instrumento para a coleta de dados da pesquisa "Estilos parentais, habilidades sociais e problemas de comportamento em adolescentes" coordenado pela professora Doutora Alessandra Turini Bolsoni- Silva, docente do Mestrado em Psicologia da aprendizagem e do desenvolvimento da Universidade Estadual Paulista do campus de Bauru (UNESP-Bauru).

Através desta autorização a pós-graduanda Gabriela Mello Sabbag (CRP 08/10610) estará num primeiro momento aplicando os questionários em sala de aula nas instituições selecionadas aleatoriamente. E num segundo momento, a partir da seleção de alguns participantes (aproximadamente 50 adolescentes), a pesquisadora convidará as mães destes para uma entrevista sobre a relação pais e filhos, um questionário sobre práticas educativas e outro acerca do comportamento do(a) filho(a) participante a ser realizado de preferência na escola ou no domicílio das participantes.

Como forma de agradecimento aos pais e de intervenção direcionada aos mesmos, eu me proponho a realizar a palestra "Pais presentes, Pais Ausentes" para pais e filhos das 
escolas participantes. A palestra aborda formas de aprimorar a relação entre pais e filhos. A palestra deverá ser realizada após a pesquisa para não interferir nas respostas dos pais, isto é, se for realizada antes da aplicação da entrevista e do questionário os pais podem ser induzidos a responder de acordo com o que a palestra propõe. Por essa razão a pesquisa é cautelosa neste quesito.

Desde já agradeço a atenção e estou à disposição para quaisquer dúvidas e/ou modificações que sejam necessárias para o aceite da realização desta pesquisa. Sendo aprovada e autorizada a realização desta pesquisa peço encarecidamente um ofício de autorização da pesquisa.

Curitiba, 23 de abril de 2008.

Pesquisadora mestranda em psicologia: Gabriela Mello Sabbag Psicóloga (CRP: 08/10610)

Telefone para contato: 41-3254-1797 41-9135-9115

E-mail: gabi_s@hotmail.com 
APÊNDICE B - Carta de aprovação emitida pelo Comitê de Ética em pesquisa da UNESP 
APÊNDICE C - Carta de autorização da pesquisa emitida pela Secretária de Educação do Estado do Paraná 
APÊNDICE D - Carta aos diretores das escolas para solicitar a permissão da pesquisa.

\section{À diretoria da instituição:}

Venho por meio desta, solicitar a autorização desta instituição para a realização da pesquisa: "Estilos parentais, habilidades sociais e problemas de comportamento em adolescentes".

A pesquisa constará de duas fases. Na primeira fase será realizada a aplicação dos questionários sobre as práticas educativas parentais e sobre os comportamentos autoobservados em adolescentes estudantes deste colégio. A segunda fase será realizada a partir da seleção de algumas mães dos participantes (aproximadamente 50), as mesmas serão convidadas para uma entrevista estruturada sobre a relação pais e filhos e a responderem a dois questionários: um sobre práticas educativas e outro sobre os comportamentos que observa em seu (sua) filho(a) participante.

Estes questionários e a entrevista serão o meio de instrumento para a coleta de dados da pesquisa "Estilos parentais, habilidades sociais e problemas de comportamento em adolescentes" coordenado pela professora Doutora Alessandra Turini Bolsoni- Silva, docente do Mestrado em Psicologia da aprendizagem e do desenvolvimento da Universidade Estadual Paulista do campus de Bauru (UNESP-Bauru).

Através desta autorização a pós-graduanda Gabriela Mello Sabbag estará num primeiro momento aplicando os questionários em sala de aula nesta instituição. E num segundo momento, a partir da seleção de alguns participantes (aproximadamente 50 adolescentes), a pesquisadora convidará as mães destes para uma entrevista sobre a relação pais e filhos, um questionário sobre práticas educativas e outro acerca do comportamento do(a) filho(a) participante a ser realizado de preferência na escola ou no domicílio das participantes.

Curitiba, 20 de abril de 2008.

Pesquisadora responsável: Gabriela Mello Sabbag

Telefone para contato: $9135-9115$

E-mail: gabi_s@hotmail.com Psicóloga (CRP: 08/10610) 
APÊNDICE E - Carta aos pais para autorização da participação dos filhos

Termo de autorização para participação de menores de dezoito anos

Pesquisadora responsável: Psicóloga Gabriela Mello Sabbag

CRP 08/10610

Pesquisadora Orientadora da Pesquisa: Alessandra Turini Bolsoni Silva

\section{Informações dadas aos responsáveis:}

Estamos realizando uma pesquisa com mães e filhos adolescentes estudantes, na faixa etária de 11 a 16 anos de idade.

Por meio desta solicitamos a autorização para que seu filho responda a um questionário em sala de aula sobre a relação dele com a mãe. Sem prejuízo as atividades pedagógicas de seu filho, conforme foi solicitado e exigido pela secretaria da educação do estado do Paraná.

Você tem a liberdade de autorizar ou não a participação do seu filho, sem prejuízo algum.

Esta pesquisa fornecerá informações importantes para futuras intervenções para relação pais e filhos, assim você e seu filho estarão ajudando outros adolescentes e pais no futuro. Destacando que as atividades futuramente realizadas não objetivam a exposição de pais e filhos, nem será realizada tal exposição. Os dados desta pesquisa serão apresentados de modo geral, isto é, sobre a população em estudo e não sobre um caso específico de uma família.

Nós as pesquisadoras estamos compromissadas com o Código de Ética Profissional do Psicólogo, assegurando total sigilo quanto aos dados obtidos durante a pesquisa.

Antecipadamente agradecemos a sua atenção.

$\mathrm{Eu}$, (nome do responsável), autorizo a participação de meu filho(a) (nome do adolescente) nesta pesquisa, sabendo que ele e eu não seremos expostos e não teremos prejuízo algum.

Curitiba, de de 2008. 
APÊNDICE F - Carta de informação aos adolescentes sobre a pesquisa

Pesquisadora responsável: Psicóloga Gabriela Mello Sabbag

CRP 08/10610

Pesquisadora Orientadora: Alessandra Turini Bolsoni Silva

\section{Informações dadas aos adolescentes}

Estamos realizando uma pesquisa com mães e filhos adolescentes estudantes, na faixa etária de 11 a 16 anos de idade.

Você respondeu a um questionário sobre a relação com sua mãe.

Você tem a liberdade de aceitar ou não a participar desta pesquisa.

Esta pesquisa fornecerá informações importantes para futuras intervenções para relação pais e filhos, assim você estará ajudando outros adolescentes e pais no futuro. Destacando que as atividades futuramente realizadas não objetivam a exposição de pais e filhos, nem será realizada tal exposição. Os dados desta pesquisa serão apresentados de modo geral, isto é, sobre a população em estudo e não sobre um caso específico de uma família.

Nós as pesquisadoras estamos compromissadas com o Código de Ética Profissional do Psicólogo, assegurando total sigilo quanto aos dados obtidos durante a pesquisa.

Antecipadamente agradecemos a sua atenção. 
APÊNDICE G - Termo de consentimento livre esclarecido para mães

Pesquisadora responsável: Psicóloga Gabriela Mello Sabbag

CRP 08/10610

Pesquisadora Orientadora: Alessandra Turini Bolsoni Silva

Informações dadas aos responsáveis: Estamos realizando uma pesquisa com mães e filhos estudantes, na faixa etária de 11 a 16 anos de idade.

Você, mãe participante desta pesquisa, respondeu a um questionário, onde a pesquisadora fez perguntas e anotou as respostas, abordando questões sobre relacionamento entre pais e filhos e outro questionário sobre os comportamentos de seu filho. $\mathrm{O}$ seu filho participou desta pesquisa respondendo a um questionário em sala de aula, sobre a relação com seus pais.

Você e seu filho não terão despesas ao participar desta pesquisa. Você e seu filho têm a liberdade de se recusar a participar, de não responder a uma pergunta e de retirar seu consentimento, a qualquer momento, caso algo desagrade, sem qualquer problema.

Esta pesquisa fornecerá informações importantes para futuras intervenções para relação pais e filhos, assim você estará ajudando outros pais e adolescentes no futuro. Destacando que as atividades futuramente realizadas não objetivam a exposição de mães e filhos, nem será realizada tal exposição. Os dados desta pesquisa serão apresentados de modo geral, isto é, sobre a população em estudo e não sobre um caso específico de uma família.

Nós as pesquisadoras estamos compromissadas com o Código de Ética Profissional do Psicólogo, assegurando total sigilo quanto aos dados obtidos durante a pesquisa.

Antecipadamente agradecemos a sua atenção.

$\mathrm{Eu}$,

$\mathrm{RG}$

abaixo assinado, estou ciente de que faço parte de uma amostra de pesquisa sobre relacionamento entre pais e filhos. Eu e meu filho estamos contribuindo com dados através das respostas aos questionários e da entrevista realizada. Declaro estar ciente: a) do objetivo desta pesquisa; b) da segurança de que não seremos identificados, de que será mantido o caráter confidencial das informações relacionadas com nossa privacidade e; c) de ter a liberdade de recusar a participar da pesquisa.

Curitiba, de de 2008.

Assinatura do responsável

Nome do responsável

Assinatura da pesquisadora responsável 
ANEXO 
ANEXO A - Descrição das categorias de análise do Roteiro de Entrevista de Habilidades Sociais Educativas Parentais- RE-HSE-P (BOLSONI-SILVA, 2009)

As categorias de comportamentos parentais, propostas por Bolsoni-Silva (2008), abrangem três grandes áreas que envolvem as habilidades sociais de comunicação, expressividade e de estabelecimento de limites, as quais são apresentadas literalmente a seguir. Quanto à comunicação tem-se: assuntos para conversação e realização de perguntas, bem como o contexto adequado ou não para a comunicação (ocasiões da comunicação). De acordo com a autora (BOLSONI-SILVA, 2008, p.147):

a) Assuntos relativos a manter conversação: comportamentos verbais de forma a iniciar e/ou manter episódios verbais com os filhos, sendo o caso de conversar sobre a escola, brincadeiras, esportes, amizades, jogos;

b) Assuntos relativos a fazer perguntas: comportamentos verbais de forma a questionar os filhos sobre o que aconteceu durante o dia, sobre gostos e opiniões dos filhos, por exemplo, sobre a escola, sobre esporte, televisão, sentimentos e atividades do dia-a-dia;

c) Ocasiões em que a comunicação ocorre: por exemplo, frente a perguntas e pedidos dos filhos, em situações de lazer ou em diversos momentos do dia, tais como à noite, nas refeições, durantes as tarefas escolares.

Para facilitar o entendimento, Bolsoni-Silva (2009) elaborou um quadro geral com a apresentação das categorias e subcategorias do seu instrumento. Esse contém a descrição dos comportamentos das mães e dos filhos referentes à categoria comunicação. Em específico, faz menção às diferentes subcategorias.

Os quadros 1, 2 e 3 apresentam as descrições das contingências referentes à subcategoria conversa, faz perguntas e perguntas de sexualidade, respectivamente. 


\begin{tabular}{|c|c|c|c|c|c|}
\hline \multirow{7}{*}{ CONVERSA } & \multirow{2}{*}{$\begin{array}{l}\text { Antecedentes do } \\
\text { comportamento } \\
\text { materno }\end{array}$} & Situação & $\begin{array}{l}\text { conversa } \\
\text { diante de } \\
\text { problemas } \\
\text { do filho } \\
\end{array}$ & $\begin{array}{l}\text { problemas } \\
\text { externalizantes }\end{array}$ & Diante de externalizantes \\
\hline & & Situação & contexto & $\begin{array}{l}\text { momentos do } \\
\text { dia }\end{array}$ & $\begin{array}{l}\text { Em diversos } \\
\text { momentos do dia } \\
\text { (tais como à noite, } \\
\text { nas refeições, } \\
\text { durantes as tarefas } \\
\text { escolares) }\end{array}$ \\
\hline & \multirow[t]{2}{*}{$\begin{array}{l}\text { Comportamento } \\
\text { materno }\end{array}$} & Assuntos & contexto & diversos & $\begin{array}{l}\text { Temas diversos (cotidiano, } \\
\text { colegas, sobre a família, } \\
\text { religião, trabalho, } \\
\text { sentimentos) }\end{array}$ \\
\hline & & Assuntos & contexto & certo/errado & $\begin{array}{l}\text { Concepções de certo ou } \\
\text { errado }\end{array}$ \\
\hline & \multirow{3}{*}{$\begin{array}{l}\text { Comportamento } \\
\text { dos filhos }\end{array}$} & Reação filho & $\begin{array}{l}\text { habilidade } \\
\text { social do } \\
\text { filho }\end{array}$ & habilidoso & $\begin{array}{l}\text { Disponibilidade social, } \\
\text { cooperação e expressão } \\
\text { sentimentos }\end{array}$ \\
\hline & & Reação filho & $\begin{array}{l}\text { problema } \\
\text { do filho }\end{array}$ & não habilidoso & $\begin{array}{l}\text { Problemas externalizantes } \\
\text { (conversa brabo, } \\
\text { agressivo), internalizantes } \\
\text { (não fala nada) }\end{array}$ \\
\hline & & Reação filho & $\begin{array}{l}\text { problema } \\
\text { do filho }\end{array}$ & "normal" & Outros (fica normal) \\
\hline
\end{tabular}

Quadro 1 - Descrição da categoria comunicação, subcategoria conversa Fonte: Bolsoni-Silva (2009)

\begin{tabular}{|l|l|l|l|l|l|}
\hline \multirow{2}{*}{$\begin{array}{l}\text { FAZ } \\
\text { PERGUNTAS }\end{array}$} & $\begin{array}{l}\text { Contingências } \\
\text { contextuais }\end{array}$ & $\begin{array}{l}\text { Assuntos sobre } \\
\text { os quais a mãe } \\
\text { conversa }\end{array}$ & contexto & diversos & $\begin{array}{l}\text { Temas diversos } \\
\text { (obrigações, atividades } \\
\text { do dia, família, } \\
\text { sentimentos) }\end{array}$ \\
\cline { 2 - 6 } & $\begin{array}{l}\text { Comportamento } \\
\text { dos filhos }\end{array}$ & Reação filho & $\begin{array}{l}\text { problema } \\
\text { do filho }\end{array}$ & não habilidoso & $\begin{array}{l}\text { Problemas } \\
\text { externalizantes, } \\
\text { internalizantes }\end{array}$ \\
\cline { 2 - 5 } & Reação filho & $\begin{array}{l}\text { habilidade } \\
\text { social do } \\
\text { filho }\end{array}$ & $\begin{array}{l}\text { disponibilidade } \\
\text { social }\end{array}$ & $\begin{array}{l}\text { Disponibilidade social e } \\
\text { cooperação }\end{array}$ \\
\hline
\end{tabular}

Quadro 2 - Descrição da categoria comunicação, subcategoria faz perguntas Fonte: Bolsoni-Silva (2009)

\begin{tabular}{|l|l|l|l|l|l|}
\hline \multirow{2}{*}{$\begin{array}{l}\text { PERGUNTAS } \\
\text { SEXUALIDADE }\end{array}$} & $\begin{array}{l}\text { Mãe faz } \\
\text { Comportamento } \\
\text { materno }\end{array}$ & $\begin{array}{l}\text { Sentimentos } \\
\text { da mãe }\end{array}$ & $\begin{array}{l}\text { habilidade } \\
\text { social } \\
\text { educativa }\end{array}$ & Sente-se bem & Sente-se bem/normal \\
\cline { 2 - 5 } & sexual & $\begin{array}{l}\text { Relacionamento sexual, } \\
\text { namoro/beijo/prevenção }\end{array}$ \\
\cline { 2 - 6 } & $\begin{array}{l}\text { Comportamento } \\
\text { do filho }\end{array}$ & $\begin{array}{l}\text { Reação } \\
\text { filho }\end{array}$ & $\begin{array}{l}\text { habilidade } \\
\text { social do } \\
\text { filho }\end{array}$ & habilidoso & $\begin{array}{l}\text { Disponibilidade social, } \\
\text { cooperação, expressa } \\
\text { opiniões }\end{array}$ \\
\hline
\end{tabular}

Quadro 3 - Descrição da categoria comunicação, subcategoria perguntas sobre sexualidade Fonte: Bolsoni-Silva (2009)

A habilidade educativa parental de expressão de sentimentos e enfrentamento é definida como referente aos comportamentos verbais das mães para expressar sentimentos positivos, negativos e opiniões, demonstrar carinho, brincar com o filho, os quais são detalhados conforme classificação de Bolsoni-Silva (2008, p.147): 
a) Formas de expressar sentimentos positivos: comportamentos verbais manifestando sentimentos de satisfação, por exemplo, apenas pela expressão do rosto, falando, elogiando, abraçando, beijando, agradando, dando presentes;

b) Formas de expressar sentimentos negativos: comportamentos verbais manifestando sentimentos de desagrado, tais como só pela expressão do rosto, falando, ficando bravo, gritando, batendo;

c) Formas de expressar opiniões: comportamentos verbais manifestando a opinião (concordante ou discordante), em relação a algo que o filho esteja fazendo ou dizendo, seja sobre a qualidade da refeição, concepções de certo e errado, sobre a escola (atividades acadêmicas e/ou interpessoais), ou sobre roupas, amizades, televisão, religião;

d) Formas de demonstrar carinho: comportamentos verbais e/ou não-verbais de agrado aos filhos, tais como beijando, abraçando, tocando, elogiando, ajudando a criança a resolver problemas;

e) Brincar com o filho: habilidades verbais e/ou não-verbais de iniciar e manter brincadeiras com os filhos, podendo ser, por exemplo, jogos e/ou leitura de livros;

f) Ocasiões em que as habilidades de expressão e enfrentamento ocorrem: por exemplo, frente a perguntas e pedidos dos filhos, em situações de lazer ou em diversos momentos do dia (tais como à noite, nas refeições, durantes as tarefas escolares etc.), quando o filho faz algo considerado apropriado, frente a comportamentos externalizantes, frente a comportamentos internalizantes.

Para a compreensão da categoria expressão de sentimentos e enfrentamento são apresentados os quadros sobre expressão de sentimentos positivos (Quadro 4), expressão de sentimentos negativos (Quadro 5), expressão de opiniões (Quadro 6) e demonstração de carinho (Quadro 7), conforme Bolsoni-Silva (2009):

\begin{tabular}{|l|l|l|l|l|l|}
\hline \multirow{2}{*}{$\begin{array}{l}\text { SENTIMENTOS } \\
\text { POSITIVOS }\end{array}$} & $\begin{array}{l}\text { Comportamento da } \\
\text { Comportamento } \\
\text { materno }\end{array}$ & $\begin{array}{l}\text { habilidade } \\
\text { social } \\
\text { educativa } \\
\text { materna }\end{array}$ & $\begin{array}{l}\text { sentimentos e } \\
\text { enfrentamento }\end{array}$ & $\begin{array}{l}\text { Expressando } \\
\text { sentimentos (agradando, } \\
\text { fazendo carinho) }\end{array}$ \\
\cline { 3 - 5 } & $\begin{array}{l}\text { Comportamento da } \\
\text { mãe }\end{array}$ & $\begin{array}{l}\text { habilidade } \\
\text { social } \\
\text { educativa } \\
\text { materna }\end{array}$ & $\begin{array}{l}\text { comunicando- } \\
\text { se }\end{array}$ & $\begin{array}{l}\text { Comunicando-se } \\
\text { (conversando, } \\
\text { elogiando) }\end{array}$ \\
\hline
\end{tabular}

Quadro 4 - Descrição da categoria expressão de sentimentos e enfrentamento, subcategoria expressão de sentimentos positivos

Fonte: Bolsoni-Silva (2009) 


\begin{tabular}{|c|c|c|c|c|c|}
\hline \multirow{9}{*}{$\begin{array}{l}\text { SENTIMENTOS } \\
\text { NEGATIVOS }\end{array}$} & \multirow[b]{2}{*}{$\begin{array}{l}\text { Antecedentes do } \\
\text { contexto materno }\end{array}$} & Situações & contexto & $\begin{array}{l}\text { problemas das } \\
\text { mães }\end{array}$ & $\begin{array}{l}\text { Problemas pessoais das } \\
\text { mães (cansaço, irritado) }\end{array}$ \\
\hline & & Situações & contexto & diversos & $\begin{array}{l}\text { Em diversos momentos } \\
\text { (despedir-se para } \\
\text { dormir, ao acordar, } \\
\text { quando está junto) }\end{array}$ \\
\hline & $\begin{array}{l}\text { Antecedentes do } \\
\text { comportamento } \\
\text { materno }\end{array}$ & Situações & $\begin{array}{l}\text { prática } \\
\text { negativa }\end{array}$ & outros & Depois que deu bronca \\
\hline & $\begin{array}{l}\text { Antecentes- } \\
\text { problemas de } \\
\text { comportamento } \\
\text { dos filhos }\end{array}$ & Situações & $\begin{array}{l}\text { problema } \\
\text { do filho }\end{array}$ & descuido & $\begin{array}{l}\text { Descuido com o } \\
\text { ambiente e com as } \\
\text { próprias coisas }\end{array}$ \\
\hline & $\begin{array}{l}\text { Antecedentes- } \\
\text { habilidades } \\
\text { sociais do filho }\end{array}$ & Situações & $\begin{array}{l}\text { habilidade } \\
\text { social do } \\
\text { filho }\end{array}$ & $\begin{array}{l}\text { faz coisas que } \\
\text { gosta }\end{array}$ & $\begin{array}{l}\text { Quando o filho faz algo } \\
\text { legal, de que a mãe } \\
\text { gosta }\end{array}$ \\
\hline & & $\begin{array}{l}\text { Comportamento } \\
\text { da mãe }\end{array}$ & $\begin{array}{l}\text { prática } \\
\text { negativa }\end{array}$ & $\begin{array}{l}\text { não } \\
\text { habilidoso }\end{array}$ & Ativo (fica bravo/grita) \\
\hline & $\begin{array}{l}\text { Comportamento } \\
\text { materno }\end{array}$ & $\begin{array}{l}\text { Comportamento } \\
\text { da mãe }\end{array}$ & $\begin{array}{l}\text { habilidade } \\
\text { social } \\
\text { educativa } \\
\text { materna }\end{array}$ & habilidoso & $\begin{array}{l}\text { Comunicando-se } \\
\text { (falando/conversando) }\end{array}$ \\
\hline & Comportamento & Reação filho & $\begin{array}{l}\text { habilidade } \\
\text { social do } \\
\text { filho }\end{array}$ & $\begin{array}{l}\text { sentimentos e } \\
\text { enfrentamento }\end{array}$ & $\begin{array}{l}\text { Reinvidica direitos, } \\
\text { obedece, escuta }\end{array}$ \\
\hline & dos filhos & Reação filho & $\begin{array}{l}\text { habilidade } \\
\text { social do } \\
\text { filho }\end{array}$ & $\begin{array}{l}\text { sentimentos e } \\
\text { enfrentamento }\end{array}$ & $\begin{array}{l}\text { Beija/abraça, sorri, diz } \\
\text { que ama, fica feliz/gosta }\end{array}$ \\
\hline
\end{tabular}

Quadro 5 - Descrição da categoria expressão de sentimentos e enfrentamento, subcategoria expressão de sentimentos negativos

Fonte: Bolsoni-Silva (2009)

\begin{tabular}{|c|c|c|c|c|c|}
\hline \multirow{2}{*}{$\begin{array}{c}\text { EXPRESSA } \\
\text { OPINIÕES }\end{array}$} & $\begin{array}{c}\text { Contingências } \\
\text { contextuais }\end{array}$ & Situações & contexto & diversas & Situações diversas \\
\cline { 2 - 5 } & Comportamento & Reação filho & $\begin{array}{c}\text { habilidade } \\
\text { social do } \\
\text { filho }\end{array}$ & $\begin{array}{c}\text { sentimentos e } \\
\text { enfrentamento }\end{array}$ & $\begin{array}{c}\text { Obedece, } \\
\text { explica/expressa propria } \\
\text { opiniao }\end{array}$ \\
\cline { 2 - 5 } & Reação filho & $\begin{array}{c}\text { problema } \\
\text { do filho }\end{array}$ & $\begin{array}{c}\text { socialmente } \\
\text { indesejados }\end{array}$ & $\begin{array}{c}\text { Internalizantes (ouve e } \\
\text { não diz nada, não gosta) }\end{array}$ \\
\hline
\end{tabular}

Quadro 6 - Descrição da categoria expressão de sentimentos e enfrentamento, subcategoria expressão de opiniões

Fonte: Bolsoni-Silva (2009) 


\begin{tabular}{|c|c|c|c|c|c|}
\hline \multirow{6}{*}{$\begin{array}{l}\text { FAZ } \\
\text { CARINHO }\end{array}$} & $\begin{array}{l}\text { Antecedentes do } \\
\text { contexto materno }\end{array}$ & Situações & contexto & lazer & $\begin{array}{l}\text { Em situações de lazer } \\
\text { (destaque tv, } \\
\text { computador) }\end{array}$ \\
\hline & \multirow{2}{*}{$\begin{array}{l}\text { Antecedentes do } \\
\text { comportamento } \\
\text { materno }\end{array}$} & Situações & $\begin{array}{l}\text { habilidade } \\
\text { social } \\
\text { educativa } \\
\text { materna }\end{array}$ & não está bem & $\begin{array}{l}\text { Quando a criança não } \\
\text { está bem }\end{array}$ \\
\hline & & Situações & $\begin{array}{l}\text { habilidade } \\
\text { social } \\
\text { educativa } \\
\text { materna }\end{array}$ & $\begin{array}{l}\text { faz coisas } \\
\text { que gosta }\end{array}$ & $\begin{array}{l}\text { Quando a criança faz } \\
\text { coisas que a mãe gosta }\end{array}$ \\
\hline & $\begin{array}{l}\text { Comportamento } \\
\text { materno }\end{array}$ & $\begin{array}{l}\text { Comportamento } \\
\text { da mãe }\end{array}$ & $\begin{array}{l}\text { habilidade } \\
\text { social } \\
\text { educativa } \\
\text { materna }\end{array}$ & habilidoso & $\begin{array}{l}\text { Diz que ama, abraça, } \\
\text { beija, elogia, toca, } \\
\text { atende pedidos }\end{array}$ \\
\hline & \multirow[t]{2}{*}{$\begin{array}{l}\text { Comportamento } \\
\text { dos filhos }\end{array}$} & Reação filho & $\begin{array}{l}\text { habilidade } \\
\text { social do } \\
\text { filho }\end{array}$ & $\begin{array}{l}\text { disponibilida } \\
\text { de social }\end{array}$ & $\begin{array}{l}\text { Disponibilidade social e } \\
\text { cooperação, expressa } \\
\text { sentimentos e } \\
\text { enfrentamento- } \\
\text { beija/abraça, sorri, diz } \\
\text { que ama }\end{array}$ \\
\hline & & Reação filho & $\begin{array}{l}\text { problema } \\
\text { do filho }\end{array}$ & $\begin{array}{l}\text { não } \\
\text { habilidoso }\end{array}$ & $\begin{array}{l}\text { Internalizantes e } \\
\text { externalizantes }\end{array}$ \\
\hline
\end{tabular}

Quadro 7 - Descrição da categoria expressão de sentimentos e enfrentamento, subcategoria faz carinho Fonte: Bolsoni-Silva (2009)

A descrição das classes de comportamentos de estabelecimento de limites de Bolsoni-

Silva (2008, p.148) compreendem:

a) Razões dadas pelos pais para justificar o estabelecimento de limites, por exemplo para orientar/ensinar o que é certo ou errado, de forma a ensinar o filho a ter responsabilidades e a saber quais comportamentos são esperados;

b) Identificação dos comportamentos que consideram apropriados aos filhos: comportamentos verbais dos pais/cuidadores de relatar comportamentos dos filhos que gostam, por exemplo, obedecer, cuidar dos próprios pertences, conversar calmamente, estudar, oferecer ajuda;

c) Identificação dos comportamentos que não consideram apropriados aos filhos: comportamentos verbais dos pais/cuidadores de relatar comportamentos dos filhos que não gostam, por exemplo, brigar, gritar, desobedecer, tirar notas baixas, fazer birras;

d) Cumprimento de promessas: comportamentos verbais dos pais/cuidadores de identificar dificuldades, situações e reações dos filhos diante de promessas previamente feitas a eles;

e) Conversações com cônjuge visando maximizar a consistência nas práticas educativas: comportamentos verbais dos pais/cuidadores de identificar o quanto e quais os motivos que concordam e discordam do cônjuge no que tange à educação dos filhos; identificar como reagem diante de concordâncias e/ou de discordâncias;

f) Identificar os próprios "erros": comportamentos verbais dos pais/cuidadores quanto à auto-reflexão acerca dos próprios comportamentos, sugere autoconhecimento, por exemplo, os pais/cuidadores relatam sentir culpa por bater, pois entendem como errado o uso de tal prática educativa;

g) Ocasiões em que os filhos comportam-se de forma que os pais necessitem estabelecer limites, sendo o caso de horário para banho, uso de televisão e de videogame, alimentação, organização dos próprios objetos e de outros;

h) Comportamentos verbais e/ou não-verbais diante de comportamentos dos filhos que justificam o estabelecimento de limites, tais como dizer não com explicação, dizer não sem explicação, colocar de castigo, bater, gritar, conversar, pedir mudança de comportamento. 
Para melhor compreensão das subcategorias do estabelecimento de limites, foram elaborados os quadros 8, 9, 10, 11 e 12 referentes à estabelecer limites, à mãe conseguir identificar seus erros nas práticas educativas, ao filho fazer coisas que a mãe gosta, ao filho fazer coisas que a mãe não gosta e ao entendimento entre o casal sobre as práticas educativas, respectivamente.

\begin{tabular}{|c|c|c|c|c|c|}
\hline \multirow{11}{*}{$\begin{array}{l}\text { ESTABELECER } \\
\text { LIMITES }\end{array}$} & \multirow{4}{*}{$\begin{array}{l}\text { Antecedentes- } \\
\text { Razões para } \\
\text { limites }\end{array}$} & Motivos & contexto & controle & $\begin{array}{l}\text { Para ter controle sobre o } \\
\text { comportamento do filho, } \\
\text { para ele ser obediente, } \\
\text { responsável, se adapte a } \\
\text { sociedade }\end{array}$ \\
\hline & & Motivos & contexto & $\begin{array}{l}\text { limites e } \\
\text { regras na } \\
\text { vida }\end{array}$ & $\begin{array}{l}\text { Porque há limites e } \\
\text { regras em todas as } \\
\text { esferas da vida }\end{array}$ \\
\hline & & Motivos & contexto & $\begin{array}{l}\text { saúde dos } \\
\text { filhos }\end{array}$ & Saúde dos filhos \\
\hline & & Motivos & contexto & certo/errado & $\begin{array}{l}\text { Para orientar concepções } \\
\text { de certo/errado, como o } \\
\text { filho deve se comportar }\end{array}$ \\
\hline & \multirow{4}{*}{$\begin{array}{l}\text { Antecedentes } \\
\text { contextuais } \\
\text { situacionais }\end{array}$} & Situações & contexto & lazer & $\begin{array}{l}\text { Em situações de lazer } \\
\text { (tv, vídeo, vídeo game, } \\
\text { sair, brincadeiras, } \\
\text { internet) }\end{array}$ \\
\hline & & Situações & contexto & alimentos & Alimentos \\
\hline & & Situações & problema & descuido & $\begin{array}{l}\text { Descuido com o } \\
\text { ambiente e próprias } \\
\text { coisas }\end{array}$ \\
\hline & & $\begin{array}{l}\text { Sentimentos da } \\
\text { mãe }\end{array}$ & $\begin{array}{l}\text { habilidade } \\
\text { social } \\
\text { educativa } \\
\text { materna }\end{array}$ & sente-se bem & Sente-se bem, feliz \\
\hline & \multirow[t]{2}{*}{$\begin{array}{l}\text { Comportamento } \\
\text { materno }\end{array}$} & $\begin{array}{l}\text { Comportamento } \\
\text { da mãe }\end{array}$ & $\begin{array}{l}\text { habilidade } \\
\text { social } \\
\text { educativa } \\
\text { materna }\end{array}$ & habilidoso & Conversa, negocia \\
\hline & & $\begin{array}{l}\text { Comportamento } \\
\text { da mãe }\end{array}$ & $\begin{array}{l}\text { prática } \\
\text { negativa }\end{array}$ & $\begin{array}{l}\text { não } \\
\text { habilidoso }\end{array}$ & Ativo e passivo \\
\hline & $\begin{array}{l}\text { Comportamento } \\
\text { dos filhos }\end{array}$ & $\begin{array}{l}\text { Comportamento } \\
\text { do filho }\end{array}$ & $\begin{array}{l}\text { problema } \\
\text { do filho }\end{array}$ & $\begin{array}{l}\text { socialmente } \\
\text { indesejado }\end{array}$ & Socialmente indesejado \\
\hline
\end{tabular}

Quadro 8 - Descrição da categoria estabelecimento de limites, subcategoria estabelece limites

Fonte: Bolsoni-Silva (2009)

\begin{tabular}{|l|l|l|l|l|l|}
\hline \multirow{2}{*}{$\begin{array}{l}\text { IDENTIFICA } \\
\text { ERROS }\end{array}$} & $\begin{array}{l}\text { Antecedentes do } \\
\text { comportamento } \\
\text { materno para } \\
\text { identificação de } \\
\text { seus erros }\end{array}$ & Situações & $\begin{array}{l}\text { Nã́tica } \\
\text { negativa }\end{array}$ & $\begin{array}{l}\text { não } \\
\text { habilidoso }\end{array}$ & $\begin{array}{l}\text { (deixa de auxiliar o } \\
\text { filho) e não habilidoso } \\
\text { ativo (fica brava, grita, } \\
\text { discute de forma } \\
\text { exagerada, coloca de } \\
\text { castigo) }\end{array}$ \\
\cline { 2 - 6 } & $\begin{array}{l}\text { Comportamento } \\
\text { materno }\end{array}$ & $\begin{array}{l}\text { Comportamento } \\
\text { da mãe }\end{array}$ & $\begin{array}{l}\text { prática } \\
\text { negativa }\end{array}$ & $\begin{array}{l}\text { prática } \\
\text { negativa }\end{array}$ & Não faz nada \\
\hline
\end{tabular}

Quadro 9 - Descrição da categoria estabelecimento de limites, subcategoria mãe identifica erros 


\begin{tabular}{|c|c|c|c|c|}
\hline \multirow{4}{*}{$\begin{array}{l}\text { FILHO FAZ } \\
\text { COISAS QUE } \\
\text { A MÃE } \\
\text { GOSTA }\end{array}$} & \multirow{2}{*}{$\begin{array}{l}\text { Antecedentes para } \\
\text { comportamentos } \\
\text { maternos }\end{array}$} & $\begin{array}{l}\text { Comportamento } \\
\text { do filho }\end{array}$ & $\begin{array}{l}\text { habilidade } \\
\text { social do } \\
\text { filho }\end{array}$ & $\begin{array}{l}\text { Sentimentos e enfrentamento (conversa, } \\
\text { estuda) }\end{array}$ \\
\hline & & $\begin{array}{l}\text { Comportamento } \\
\text { do filho }\end{array}$ & $\begin{array}{l}\text { habilidade } \\
\text { social do } \\
\text { filho }\end{array}$ & Disponibilidade social \\
\hline & $\begin{array}{l}\text { Comportamentos } \\
\text { maternos }\end{array}$ & $\begin{array}{l}\text { Comportamento } \\
\text { da mãe }\end{array}$ & $\begin{array}{l}\text { prática } \\
\text { negativa }\end{array}$ & Não habilidoso \\
\hline & $\begin{array}{l}\text { Comportamento } \\
\text { do filho }\end{array}$ & Reação filho & $\begin{array}{l}\text { habilidade } \\
\text { social do } \\
\text { filho }\end{array}$ & $\begin{array}{l}\text { Sentimentos e enfrentamento (agradece, } \\
\text { beija, abraça) }\end{array}$ \\
\hline
\end{tabular}

Quadro 10 - Descrição da categoria estabelecimento de limites, subcategoria filho faz coisas que a mãe gosta Fonte: Bolsoni-Silva (2009)

\begin{tabular}{|c|c|c|c|c|c|}
\hline \multirow{7}{*}{$\begin{array}{l}\text { FAZ COISAS } \\
\text { QUE A MÃE } \\
\text { NÃO GOSTA }\end{array}$} & $\begin{array}{l}\text { Antecedente do } \\
\text { comportamento } \\
\text { materno }\end{array}$ & $\begin{array}{l}\text { Comportamento } \\
\text { do filho }\end{array}$ & $\begin{array}{l}\text { problema } \\
\text { do filho }\end{array}$ & $\begin{array}{l}\text { indesejados } \\
\text { externalizantes }\end{array}$ & $\begin{array}{l}\text { Externalizantes } \\
\text { (desobediência, agride, } \\
\text { responde) }\end{array}$ \\
\hline & \multirow{2}{*}{$\begin{array}{l}\text { Comportamento } \\
\text { materno }\end{array}$} & $\begin{array}{l}\text { Sentimentos da } \\
\text { mãe }\end{array}$ & $\begin{array}{l}\text { prática } \\
\text { negativa }\end{array}$ & sente-se mal & $\begin{array}{l}\text { Sente-se mal (tristeza, } \\
\text { desapontamento, raiva) }\end{array}$ \\
\hline & & $\begin{array}{l}\text { Comportamento } \\
\text { da mãe }\end{array}$ & $\begin{array}{l}\text { prática } \\
\text { negativa }\end{array}$ & não habilidoso & Não habilidoso ativo \\
\hline & \multirow{4}{*}{$\begin{array}{l}\text { Comportamento } \\
\text { dos filhos }\end{array}$} & Reação filho & $\begin{array}{l}\text { habilidade } \\
\text { social }\end{array}$ & $\begin{array}{l}\text { disponibilidade } \\
\text { social }\end{array}$ & $\begin{array}{l}\text { Disponibilidade social } \\
\text { e cooperação }\end{array}$ \\
\hline & & Reação filho & $\begin{array}{l}\text { habilidade } \\
\text { social }\end{array}$ & $\begin{array}{l}\text { sentimentos e } \\
\text { enfrentamento }\end{array}$ & Pede desculpa, explica \\
\hline & & Reação filho & $\begin{array}{l}\text { problema } \\
\text { do filho }\end{array}$ & $\begin{array}{l}\text { indesejados } \\
\text { internalizantes }\end{array}$ & $\begin{array}{l}\text { "Indesejados" } \\
\text { internalizantes } \\
\text { (chora/fica triste) } \\
\end{array}$ \\
\hline & & Reação filho & $\begin{array}{l}\text { problema } \\
\text { do filho }\end{array}$ & $\begin{array}{l}\text { indesejados } \\
\text { externalizantes }\end{array}$ & $\begin{array}{l}\text { "Indesejados" } \\
\text { externalizantes } \\
\text { (chora/fica triste) }\end{array}$ \\
\hline
\end{tabular}

Quadro 11 - Descrição da categoria estabelecimento de limites, subcategoria filho faz coisas que a mãe não gosta Fonte: Bolsoni-Silva (2009)

\begin{tabular}{|c|c|c|c|c|c|}
\hline \multirow{7}{*}{$\begin{array}{l}\text { ENTENDIMENTO } \\
\text { CONJUGAL }\end{array}$} & \multirow{3}{*}{$\begin{array}{l}\text { Antecedentes } \\
\text { do casal }\end{array}$} & Porque entende & $\begin{array}{l}\text { habilidade } \\
\text { social } \\
\text { educativa } \\
\text { materna }\end{array}$ & $\begin{array}{l}\text { pensamentos } \\
\text { iguais }\end{array}$ & $\begin{array}{l}\text { Pensam igual (o casal } \\
\text { tem a mesma opinião; } \\
\text { quando um chama } \\
\text { atenção, o outro aceita) }\end{array}$ \\
\hline & & Não entende & $\begin{array}{l}\text { prática } \\
\text { negativa }\end{array}$ & $\begin{array}{l}\text { pensamentos } \\
\text { diferentes }\end{array}$ & O casal pensa diferente \\
\hline & & Não entende & $\begin{array}{l}\text { prática } \\
\text { negativa }\end{array}$ & agressividade & Um deles é agressivo \\
\hline & \multirow{2}{*}{$\begin{array}{l}\text { Comportamento } \\
\text { das mães e dos } \\
\text { pais }\end{array}$} & $\begin{array}{l}\text { Comportamento } \\
\text { to da mãe e do } \\
\text { pai }\end{array}$ & $\begin{array}{l}\text { prática } \\
\text { negativa }\end{array}$ & $\begin{array}{l}\text { frente do } \\
\text { filho }\end{array}$ & $\begin{array}{l}\text { Conversa e/ou briga na } \\
\text { frente do filho }\end{array}$ \\
\hline & & $\begin{array}{l}\text { Comportamento } \\
\text { to da mãe e do } \\
\text { pai }\end{array}$ & $\begin{array}{l}\text { habilidade } \\
\text { social } \\
\text { educativa } \\
\text { materna } \\
\end{array}$ & $\begin{array}{l}\text { ausência do } \\
\text { filho }\end{array}$ & $\begin{array}{l}\text { Conversa e/ou briga na } \\
\text { ausência do filho }\end{array}$ \\
\hline & \multirow{2}{*}{$\begin{array}{l}\text { Comportamento } \\
\text { do cônjuge }\end{array}$} & Reação cônjuge & $\begin{array}{l}\text { prática } \\
\text { negativa }\end{array}$ & $\begin{array}{l}\text { não } \\
\text { habilidoso } \\
\text { ativo }\end{array}$ & $\begin{array}{l}\text { Ficabravo/xinga, faz } \\
\text { acusações, críticas }\end{array}$ \\
\hline & & Reação cônjuge & $\begin{array}{l}\text { habilidade } \\
\text { social } \\
\text { educativa } \\
\text { materna }\end{array}$ & habilidoso & $\begin{array}{l}\text { Conversa, pede } \\
\text { desculpas, explica, pede } \\
\text { opinião, negocia }\end{array}$ \\
\hline
\end{tabular}

Quadro 12 - Descrição da categoria estabelecimento de limites, subcategoria entendimento conjugal . 
Fonte: Bolsoni-Silva (2009)

A estrutura teórica do RE-HSE-P classifica as práticas parentais em: habilidosa, não habilidosa passiva e não habilidosa ativa. A seguir a caracterização de cada uma das práticas, destacando ser uma avaliação funcional do comportamento (BOLSONI-SILVA, 2008, p.148149):

\begin{abstract}
Os habilidosos referem-se aos comportamentos de pais/cuidadores de forma a estimular o início e/ou continuidade da comunicação, bem como o estabelecimento de limites e a resolução de problemas. São comportamentos que poderiam ser denominados de práticas parentais positivas (GOMIDE, 2003), podendo maximizar a competência social (DEL PRETTE; DEL PRETTE, 2001).

Os não habilidosos passivos ocorrem quando os responsáveis relatam que não interferem nas respostas das crianças, isto é, ignoram, saem de perto, não fazem/falam nada quando o filho apresenta respostas socialmente habilidosas ou indicativas de problemas de comportamento.

Os não habilidosos ativos correspondem a práticas parentais negativas (GOMIDE, 2003): a) agressão física: utilizar intervenções físicas seja com o próprio corpo (mãos, pés), seja com outros objetos (cinta, chinelos etc.), que causem dor na criança; b) agressão verbal: xingar, gritar, repreender verbalmente a criança, fazer chantagem, humilhar; c) ameaça de agressão: ameaçar verbalmente a criança de bater, pôr de castigo, retirar privilégios; d) castigo/privação: deixar a criança privada de algo que é desejável para ela em função de um comportamento considerado indesejado ou deixar a criança sozinha em algum lugar; e) coação física: forçar a criança fisicamente a fazer algo que não queira.
\end{abstract}

Com intuito de facilitar a compreensão da avaliação dos comportamentos das mães pelo instrumento de Bolsoni-Silva (2008), elaborou-se o quadro 13:

\begin{tabular}{|c|c|c|}
\hline Classificação & Prática educativa & Descrição de comportamentos maternos \\
\hline Habilidoso & $\begin{array}{l}\text { Prática educativa } \\
\text { positiva }\end{array}$ & $\begin{array}{l}\text { Mães que estimulam o início e/ou continuidade da comunicação, } \\
\text { bem como o estabelecimento de limites e a resolução de problemas. }\end{array}$ \\
\hline $\begin{array}{l}\text { Não } \\
\text { habilidoso } \\
\text { Passivo }\end{array}$ & $\begin{array}{l}\text { Prática educativa } \\
\text { negativa }\end{array}$ & $\begin{array}{l}\text { Não interferem nas respostas dos filhos, ignoram, saem de perto, não } \\
\text { fazem/falam nada quando o filho apresenta respostas socialmente } \\
\text { habilidosas ou indicativas de problemas de comportamento. }\end{array}$ \\
\hline \multirow[t]{5}{*}{$\begin{array}{l}\text { Não } \\
\text { habilidoso } \\
\text { Ativo }\end{array}$} & \multirow[t]{5}{*}{$\begin{array}{l}\text { Prática educativa } \\
\text { negativa }\end{array}$} & $\begin{array}{l}\text { a) agressão física: utilizam intervenções físicas seja com o próprio } \\
\text { corpo (mãos, pés), seja com outros objetos (cinta, chinelos etc.), que } \\
\text { causem dor no filho. }\end{array}$ \\
\hline & & $\begin{array}{l}\text { b) agressão verbal: xingam, gritam, repreendem verbalmente o filho, } \\
\text { fazem chantagem, humilham o filho. }\end{array}$ \\
\hline & & $\begin{array}{l}\text { c) ameaçam de agressão: ameaçam verbalmente o filho de bater, pôr } \\
\text { de castigo, retirar privilégios; }\end{array}$ \\
\hline & & $\begin{array}{l}\text { d) castigo/privação: deixam o filho privado de algo que é desejável } \\
\text { para ele em função de um comportamento considerado indesejado ou } \\
\text { deixam o filho sozinho em algum lugar; }\end{array}$ \\
\hline & & $\begin{array}{l}\text { e) coação física: forçam o filho fisicamente a fazer algo que não } \\
\text { queira. }\end{array}$ \\
\hline
\end{tabular}

Quadro 13 - Classificação dos comportamentos maternos segundo o RE-HSE-P

O RE-HSE-P avalia também a funcionalidade dos comportamentos emitidos por pais e filhos segundo o relato da mãe ou do pai, isto é, os antecedentes e conseqüentes 
comportamentais parentais. As condições antecedentes e/ou conseqüentes às respostas dos pais/cuidadores em relação aos comportamentos dos filhos, a partir do relato verbal de pais/cuidadores, diante de comportamentos correspondentes a comunicação, expressão de sentimentos/enfrentamento e estabelecimento de limites de pais/cuidadores.

A partir de então, os comportamentos dos filhos também foram classificados pelo instrumento de Bolsoni-Silva (2008, p.149) em habilidosos e não habilidosos:

Os habilidosos envolvem comportamentos dos filhos de forma a comunicar-se, expressar-se e resolver problemas na interação com seus familiares. As habilidades sociais infantis são entendidas como respostas que permitem "saltos" comportamentais (BOLSONI-SILVA, 2003).

As habilidades sociais infantis foram organizadas em:

a) Disponibilidade Social e Cooperação: corresponde aos comportamentos de fazer pedidos, procurar ajudar, procurar atenção, fazer perguntas, fazer elogios, cumprimentar, tomar iniciativa;

b) Expressão de Sentimentos e Enfrentamento: corresponde aos comportamentos de expressar desejos e preferências, criticar, expressar carinho, expressar desagrado de forma habilidosa, estar de bom humor, expressar opinião, negociar, expressar os direitos e as necessidades, solicitar ajuda;

c) Interação Social Positiva: corresponde aos comportamentos de comunicar-se positivamente, fazer amizades, brincar com colegas, sorrir, ouvir atentamente.

Os comportamentos não habilidosos dos filhos correspondentes a categorias de problemas de comportamento podem prejudicar o desenvolvimento social e/ou acadêmico por dificultar o acesso a novas contingências de reforçamento (BOLSONI-SILVA; DEL PRETTE, 2003, BOLSONI-SILVA, 2008). Foram organizados por Bolsoni-Silva $(2003,2008)$ a partir da classificação de Achenbach e Edelbrock (1979) em:

a) Internalizantes: são evidenciados por retraimento, depressão, ansiedade e queixas somáticas;

b) Externalizantes: são expressos por impulsividade, agressão, agitação, características desafiantes e anti-sociais;

Para ilustrar a avaliação dos comportamentos dos filhos através do instrumento de Bolsoni-Silva (2009), elaborou-se o quadro 14:

\begin{tabular}{|c|c|c|c|}
\hline Classificação & Categorias gerais & \multicolumn{2}{|c|}{ Descrição dos comportamentos dos filhos } \\
\hline \multirow[t]{3}{*}{ Habilidoso } & $\begin{array}{l}\text { Disponibilidade social } \\
\text { e cooperação }\end{array}$ & \multicolumn{2}{|c|}{$\begin{array}{l}\text { Faz pedidos, procura ajudar, procura atenção, faz perguntas, } \\
\text { faz elogios, cumprimenta, toma iniciativas. }\end{array}$} \\
\hline & $\begin{array}{l}\text { Expressão de } \\
\text { sentimentos e } \\
\text { enfrentamento }\end{array}$ & \multicolumn{2}{|c|}{$\begin{array}{l}\text { Expressa desejos e preferências, críticas, expressa carinho, } \\
\text { expressa desagrado de forma habilidosa, bom humor, expressa } \\
\text { opinião, negocia, expressa os direitos e as necessidades, } \\
\text { solicita ajuda. }\end{array}$} \\
\hline & $\begin{array}{l}\text { Interação Social } \\
\text { Positiva }\end{array}$ & \multicolumn{2}{|c|}{$\begin{array}{l}\text { Comunica-se positivamente, faz amizades, brinca com } \\
\text { colegas, sorri, ouve atentamente. }\end{array}$} \\
\hline \multirow[t]{2}{*}{$\begin{array}{l}\text { Não } \\
\text { habilidoso }\end{array}$} & \multirow{2}{*}{$\begin{array}{l}\text { Problemas de } \\
\text { comportamento dos } \\
\text { filhos }\end{array}$} & Internalizantes & $\begin{array}{l}\text { Retraimento, depressão, ansiedade e } \\
\text { queixas somáticas. }\end{array}$ \\
\hline & & Externalizantes & $\begin{array}{l}\text { Impulsividade, agressão, agitação, } \\
\text { características desafiantes e anti-sociais. }\end{array}$ \\
\hline
\end{tabular}

Quadro 14 - Classificação dos comportamentos dos filhos segundo o RE-HSE-P 